\title{
Geologic Studies in Alaska by the U.S. Geological Survey, 1988
}

\section{U.S. GEOLOGICAL SURVEY BULLETIN 1903}

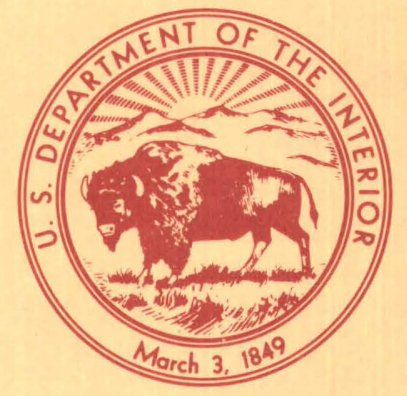




\section{AVAILABILITY OF BOOKS AND MAPS OF THE U.S. GEOLOGICAL SURVEY}

Instructions on ordering publications of the U.S. Geological Survey, along with prices of the last offerings, are given in the current-year issues of the monthly catalog "New Publications of the U.S. Geological Survey." Prices of available U.S. Geological Survey publications released prior to the current year are listed in the most recent annual "Price and Availability List." Publications that are listed in various U.S. Geological Survey catalogs (see back inside cover) but not listed in the most recent annual "Price and Availability List" are no longer available.

Prices of reports released to the open files are given in the listing "U.S. Geological Survey Open-File Reports," updated monthly, which is for sale in microfiche from the U.S. Geological Survey, Books and Open-File Reports Section, Federal Center, Box 25425, Denver, CO 80225. Reports released through the NTIS may be obtained by writing to the National Technical Information Service, U.S. Department of Commerce, Springfield, VA 22161; please include NTIS report number with inquiry.

Order U.S. Geological Survey publications by mail or over the counter from the offices given below.

\section{BY MAIL}

\section{Books}

Professional Papers, Bulletins, Water-Supply Papers, Techniques of Water-Resources Investigations, Circulars, publications of general interest (such as leaflets, pamphlets, booklets), single copies of Earthquakes \& Volcanoes, Preliminary Determination of Epicenters, and some miscellaneous reports, including some of the foregoing series that have gone out of print at the Superintendent of Documents, are obtainable by mail from

\section{U.S. Geological Survey, Books and Open-File Reports Federal Center, Box 25425 Denver, CO 80225}

Subscriptions to periodicals (Earthquakes \& Volcanoes and Preliminary Determination of Epicenters) can be obtained ONLY from the

\section{Superintendent of Documents Government Printing Office Washington, D.C. 20402} ments.)

(Check or money order must be payable to Superintendent of Docu-

\section{Maps}

For maps, address mail orders to

\section{U.S. Geological Survey, Map Distribution Federal Center, Box 25286 \\ Denver, CO 80225}

Residents of Alaska may order maps from

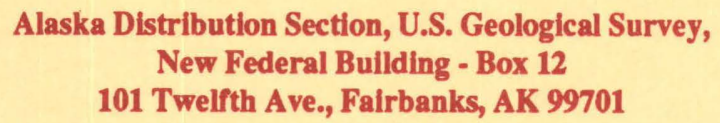

\section{OVER THE COUNTER}

\section{Books}

Books of the U.S. Geological Survey are available over the counter at the following Geological Survey Public Inquiries Offices, all of which are authorized agents of the Superintendent of Documents:

- WASHINGTON, D.C.--Main Interior Bldg., 2600 corridor, 18 th and C Sts., NW.

- DENVER, Colorado--Federal Bldg., Rm. 169, 1961 Stout St.

- LOS ANGELES; California--Federal Bldg., Rm. 7638, 300 N. Los Angeles St.

- MENLO PARK, California--Bldg. 3 (Stop 533), Rm. 3128, 345 Middlefield Rd.

- RESTON, Virginia--503 National Center, Rm. 1C402, 12201 Sunrise Valley Dr.

- SALT LAKE CITY, Utah--Federal Bldg., Rm. 8105, 125 South State St.

- SAN FRANCISCO, California--Customhouse, Rm. 504, 555 Battery St.

- SPOKANE, Washington--U.S. Courthouse, Rm. 678, West 920 Riverside Ave.

- ANCHORAGE, Alaska--Rm. 101, 4230 University Dr.

- ANCHORAGE, Alaska--Federal Bldg, Rm. E-146, 701 C St.

Maps

Maps may be purchased over the counter at the U.S. Geological Survey offices where books are sold (all addresses in above list) and at the following Geological Survey offices:

- ROLLA, Missouri--1400 Independence Rd.

- DENVER, Colorado--Map Distribution, Bldg. 810, Federal Center

- FAIRBANKS, Alaska--New Federal Bldg., 101 Twelfth Ave. 
GEOLOGIC STUDIES IN ALASKA BY THE U.S. GEOLOGICAL SURVEY, 1988 


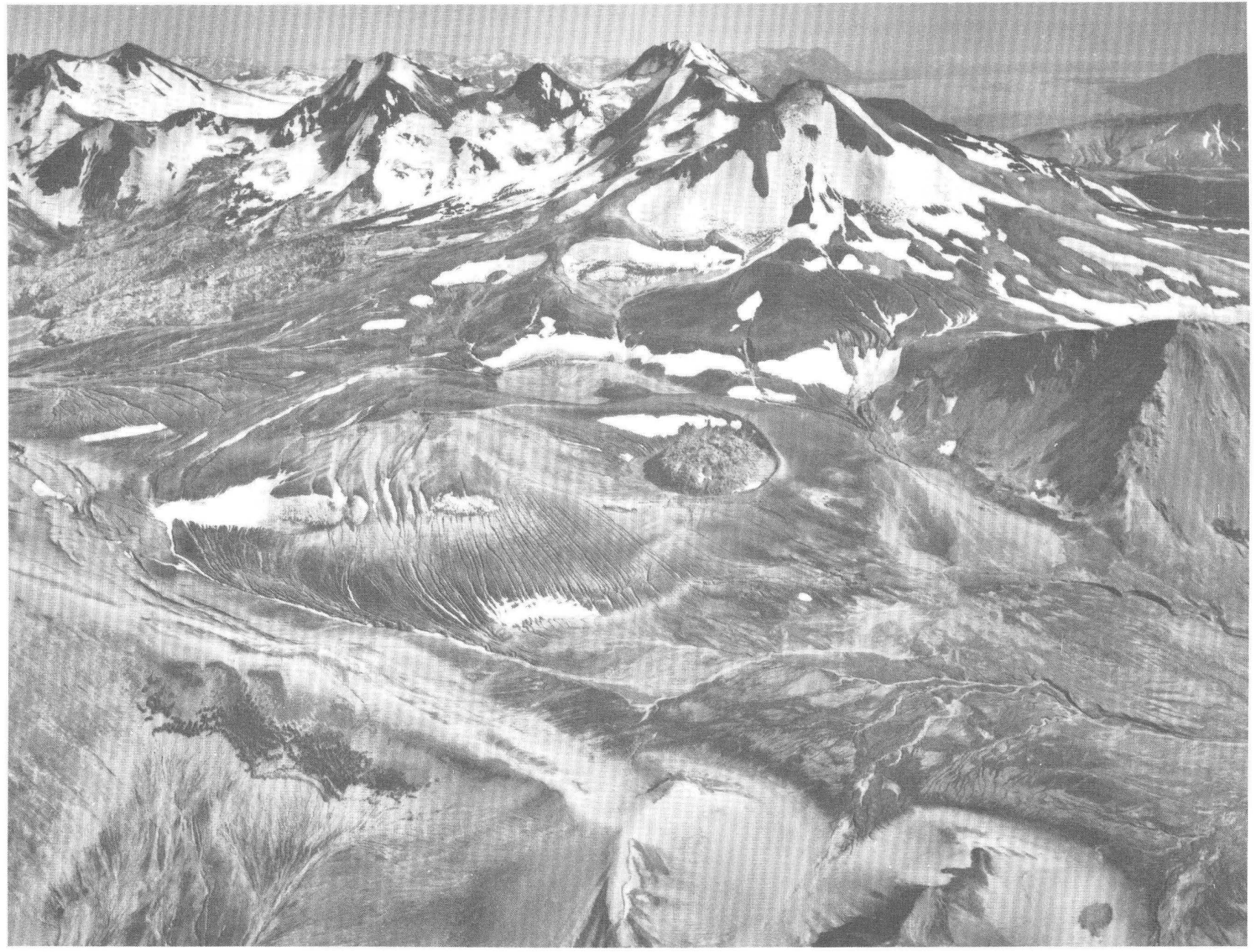

Frontispiece. Oblique aerial view looking southeast across Novarupta rhyolite dome (center of photograph) and surrounding ejecta ring and ash-flow deposits, products of 1912 eruption, Valley of Ten Thousand Smokes, Katmai National Park. Katmai volcano (top left corner) and historically active Mt. Trident volcanic center (top center) in background. Photograph provided courtesy of Thomas P. Miller and Betsy Yount. 


\section{Geologic Studies in Alaska by the U.S. Geological Survey, 1988}

JAMES H. DOVER and JOHN P. GALLOWAY, Editors 
DEPARTMENT OF THE INTERIOR

MANUEL LUJAN, JR., Secretary

U.S. GEOLOGICAL SURVEY

Dallas L. Peck, Director

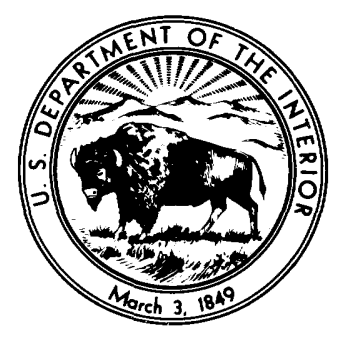

Any use of trade, product, or firm names in this publication is for descriptive purposes only and does not imply endorsement by the U.S. Government

For sale by the Books and

Open-File Reports Section, U.S. Geological Survey

Federal Center, Box 25425

Denver, CO 80225 


\section{CONTENTS}

Introduction 1

James H. Dover and John P. Galloway

The origin of natural gas hydrates on the North Slope of Alaska 3

Timothy S. Collett, Kenneth J. Bird, Keith A. Kvenvolden, and Leslie B. Magoon

Age and chemical composition of Proterozoic intrusive rocks at Mount

Angayukaqsraq, western Brooks Range, Alaska 10

Susan M. Karl, John N. Aleinikoff, Closey F. Dickey, and John T. Dillon

Proterozoic rocks of the western Brooks Range $\quad \mathbf{2 0}$

Alison B. Till

Late Cenozoic geologic controls on placer-gold distribution in the Nome nearshore area 26

Darrell S. Kaufman and David M. Hopkins

Nature of the basal contact of the Tozitna terrane along the Dalton Highway, northeast Tanana quadrangle, Alaska $\quad \mathbf{4 6}$

Thomas E. Moore and John M. Murphy

Molybdenite in the Huron Creek pluton, western Livengood quadrangle, Alaska $\quad \mathbf{5 4}$

Thomas D. Light and C. Dean Rinehart

Stratigraphy and palynology of an upper Tertiary terrace deposit of the ancestral Yukon River near Circle, Alaska $\mathbf{6 2}$

Warren Yeend, Thomas A. Ager, and J.T. Kline

In search of the provenance and paleogeographic location of the White Mountains terrane: Evidence from U-Pb data of granite boulders in the Fossil Creek Volcanics $\quad 68$

John N. Aleinikoff and George Plafker

Age of deposition and provenance of the Cleary sequence of the Fairbanks schist unit, Yukon-Tanana terrane, east-central Alaska

75 John N. Aleinikoff and Warren J. Nokleberg

Geologic setting, petrology, and age of Pliocene to Holocene volcanoes of the Stepovak Bay area, western Alaska Peninsula Frederic H. Wilson

Creation of a full color geologic map by computer: A case history from the Port Moller project resource assessment, Alaska Peninsula $\quad 96$ Frederic H. Wilson

Petrographic and chemical description of the variably deformed Speel River pluton, south of Juneau, southeastern Alaska 104 James L. Drinkwater, David A. Brew, and Arthur B. Ford

Epigenetic hydrothermal origin of the Groundhog Basin-Glacier Basin silver-tinlead-zinc deposits, southeastern Alaska Rainer J. Newberry and David A. Brew

U.S. Geological Survey reports on Alaska released in 1988 Ellen R. White, compiler

Reports about Alaska in non-USGS publications released in 1988 that include

USGS authors $\mathbf{1 3 0}$

Ellen R. White, compiler 
Denver

Aleinikoff, John N.

U.S. Geological Survey - MS 963

Box 25046 Denver Federal Center

Denver, Colorado 80225-0046

\section{Menlo Park}

U.S. Geological Survey MS 345 Middlefield Road

Menlo Park, California 94025

Brew, David A. MS 904

Bird, Kenneth J. MS 999

Collett, Timothy S. MS 999

Drinkwater, James L. MS 904

Ford, Arthur B. MS 904

Galloway, John P. MS 904

Kvenvolden, Keith A. MS 999

Magoon, Leslie B. MS 999

Moore, Thomas, E. MS 904

Murphy, John M. MS 904

Nokleberg, Warren J. MS 904

Plafker, George MS 904

Rinehart, C. Dean MS 901

White, Ellen R. MS 955

Yeend, Warren MS 904

\section{Anchorage}

U.S. Geological Survey 4200 University Drive

Anchorage, Alaska 99508-4667

Dickey, Closey F.

Dover, James $\mathrm{H}$.

Karl, Susan M.

Light, Thomas D.

Till, Alison B.

Wilson, Frederic $\mathrm{H}$.

\section{Reston}

Ager, Thomas A.

U.S. Geological Survey

National Center - MS 908

Reston, Virginia 22092

\section{Outside}

Kaufman, Darrell S.

Institute of Arctic and Alpine Research Campus Box 450

University of Colorado

Boulder, Colorado 80309-0450

Hopkins, David M.

Newberry, Rainer J.

Department of Geology and Geophysics 408 Brooks Building University of Alaska

Fairbanks, Alaska 99775-0760

Dillon, John T. (deceased)

$$
\text { Kline, J.T. }
$$

Alaska Division of

Geological and Geophysical Surveys, 3700 Airport Way

Fairbanks, Alaska 99709-4609 


\title{
Geologic Studies in Alaska by the U.S. Geological Survey, 1988
}

\author{
By James H. Dover and John P. Galloway, Editors
}

\section{INTRODUCTION}

This volume continues the annual series of U.S. Geological Survey (USGS) reports on geologic investigations in Alaska. Since 1975, when the first of these collections of short papers appeared under the title "The United States Geological Survey in Alaska: Accomplishments during 1975," the series has been published as USGS circulars. This bulletin departs from the circular style, in part to provide a more flexible format for longer reports with more depth of content, better documentation, and broader scope than is possible for circular articles.

The 13 papers in this bulletin represent a sampling of research activities carried out in Alaska by the USGS over the past few years. The topics addressed range from mineral resource studies (including natural gas) and geochemistry, Quaternary geology, basic stratigraphic and structural problems, and the use of computer graphics in geologic map preparation, to the application of geochronology to regional tectonic problems. Geographic areas represented are numbered on figure 1 and include the North Slope (1) and Brooks Range $(2,3)$ of Arctic Alaska, Seward Peninsula (4), interior Alaska (5-9), and remote locations of the Alaska Peninsula $(10,11)$ and southeast Alaska $(12,13)$.

Two bibliographies following the reports of investigations list (1) reports about Alaska in USGS publications released in 1988 and (2) reports about Alaska by USGS authors in publications outside the USGS in 1988. A bibliography and index of the short papers in past USGS circulars devoted to Geological Research and Accomplishments in Alaska (1975-1986) is published as USGS Open-File Report 87-420.

Manuscript approved for publication, June 30, 1989. 


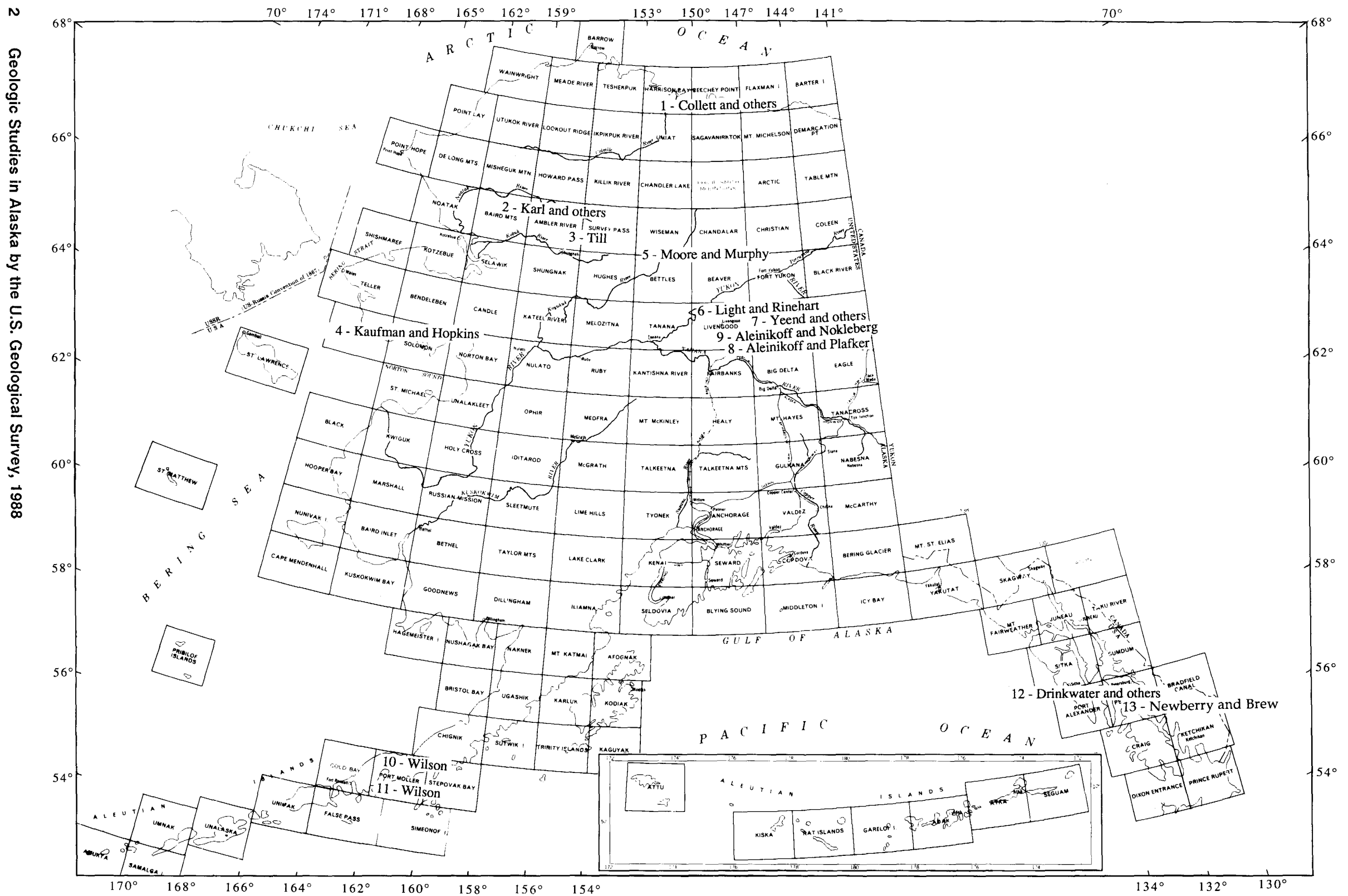

Figure 1. Index map of Alaska showing 1:250,000-scale quadrangles and general locations of study areas discussed in this bulletin. Numbers indicate order of papers in this volume; names of authors follow number. 


\title{
The Origin of Natural Gas Hydrates on the North Slope of Alaska
}

\author{
By Timothy S. Collett, Kenneth J. Bird, Keith A. Kvenvolden, and Leslie B. Magoon
}

\begin{abstract}
On the North Slope of Alaska, gas hydrates have been identified in 34 exploratory and production wells using welllog responses calibrated to the response of an interval in one well where gas hydrates were recovered in a core by ARCO and Exxon. Most gas hydrates occur in six laterally continuous Upper Cretaceous and lower Tertiary sandstone and conglomerate units; all these hydrates are geographically restricted to the area overlying the eastern part of the Kuparuk River and the western part of the Prudhoe Bay oil fields. Geochemical analyses of well samples suggest that the identified hydrates originated from a mixture of deepsource thermogenic gas and shallow microbial gas that was either directly converted to gas hydrate upon entering the zone of gas-hydrate stability or was first concentrated in existing traps and later converted to gas hydrate upon a favorable change in temperature or pore pressure. We postulate that the thermogenic gas migrated from deeper reservoirs along the same faults thought to be migration pathways for the large volumes of shallow heavy oil that occur in this area.
\end{abstract}

\section{INTRODUCTION}

Gas hydrates are crystalline substances composed of water and gas in which a solid-water lattice accommodates gas molecules in a cagelike structure, or clathrate. Gas hydrates have been known as laboratory curiosities since about 1810. Detailed studies of hydrates and their physical properties were not undertaken until Hammerschmidt (1934) published data pertaining to the plugging of natural-gas pipelines due to gas-hydrate formation. The geologic occurrence of gas hydrates has been known since the mid-1960's, when gas-hydrate accumulations were discovered in the USSR (reviewed by Makogon, 1981).

Pressure and temperature conditions suitable for the formation of gas hydrates are found in high-latitude regions of permafrost and beneath the sea in outer continental margins and ocean basins (reviewed by Kvenvolden and McMenamin, 1980). Katz (1971) was the first to recognize that temperatures and pressures associated with permafrost may fall within the stability field of gas hydrates (fig. 1). Gas hydrates can occur not only in permafrost but also below the base of permafrost at temperatures above the freezing point of water.

Significant quantities of gas hydrates have been detected in several permafrost regions of the world, including western Siberia (Makogon, 1981), the Mackenzie Delta of Canada (Bily and Dick, 1974), and the North Slope of Alaska (Galate and Goodman, 1982; Collett, 1983; Collett and others, 1988). Estimates of worldwide gas-hydrate resources in permafrost regions are as high as $10^{16} \mathrm{~m}^{3}$ of methane (Potential Gas Agency, 1981), an estimate large enough to stimulate interest in gas hydrates as a possible energy source. Gas hydrates also may be a potential drilling hazard because they can cause sediment instability and high pressures in a borehole.

In 1983 the U.S. Geological Survey and U.S. Department of Energy developed the North Slope Alaska Gas-Hydrate Research Project. Phase I of this project, completed in 1988, dealt with the evaluation of existing data in an attempt to delineate gas-hydrate occurrences in northern Alaska (fig. 2) and to evaluate the physical properties controlling gas-hydrate distribution. Phase II activities are a continuation of phase I, except that the major emphasis is to obtain new data through an active field study program. The field research includes temperature and borehole gravity surveys, formation water sampling and analysis, and geologic/ geochemical sampling and analysis of wells and outcrops.

One of the primary objectives of the project is to develop a model that describes the possible origin of gas hydrate on the North Slope. Various mechanisms for gas-hydrate formation have been postulated as reviewed by Pratt (1979) and Makogon (1981). One theory suggests that gas hydrates could be part of a preexisting gas reservoir, later solidified in place. Another theory suggests that a gas-hydrate accumulation could form by a flow of free gas into the zone of gas-hydrate stability. Migrating free gas may also be trapped at the base of the ice-bearing permafrost and converted to gas hydrate. Gas hydrates are sometimes found closely associated with 
decaying biomatter, such as coal, which may serve as a gas source. These various schemes of gas-hydrate formation can be grouped into two end-member models.

Model 1: Conversion of a preexisting gas field into a gas hydrate by a favorable change in temperature or pore pressure (fig. $3 A$ ).

Model 2: Formation of gas hydrate by continuous migration of either microbial or thermogenic gas from below into the zone of gas-hydrate stability (fig. $3 B$ ).

Relatively little is known about the history of gas-hydrate formation on the North Slope of Alaska. However, recent geologic and geochemical studies from the Prudhoe Bay-Kuparuk River area have provided us with new insights into the geologic parameters controlling the distribution of gas hydrates. The primary purpose of this report is to present a model which best describes the origin of gas hydrates in northern Alaska.

\section{GEOLOGIC SETTING}

The rocks of the North Slope can be conveniently grouped into three sequences that reflect major episodes in the tectonic development of the region. Defined on the basis of source area, these sequences proposed by
Lerand (1973) and applied to northern Alaska by Grantz and others (1975) are, in ascending order, the Franklinian sequence (Cambrian through Devonian), the Ellesmerian sequence (Mississippian through Jurassic), and the Brookian sequence (Cretaceous to Holocene).

The petroleum-bearing stratigraphic section in the Prudhoe Bay-Kuparuk River area includes the Ellesmerian and Brookian sequences. The Ellesmerian sequence consists of carbonate and siliciclastic rocks derived from a source terrane that was once north of the present coastline. The Prudhoe Bay oil field is the primary oil accumulation in the Ellesmerian sequence, with production from the Sadlerochit Group which also includes a 26 tcf (trillion cubic feet) gas cap. The Lisburne and $\mathrm{Ku}-$ paruk River oil fields also occur within the rocks of the Ellesmerian sequence. The Brookian sequence consists only of siliciclastic rocks derived from the Brooks Range to the south. The principal oil accumulations in the Prudhoe Bay-Kuparuk River area, of the Brookian sequence, are in the West Sak and Ugnu sands. These two informal names are used by ARCO to identify a series of heavy-oil-bearing sandstone units in the Kuparuk River area (Werner, 1987). All of the suspected gas-hydrate occurrences are within the Brookian sequence (Collett and others, 1988).

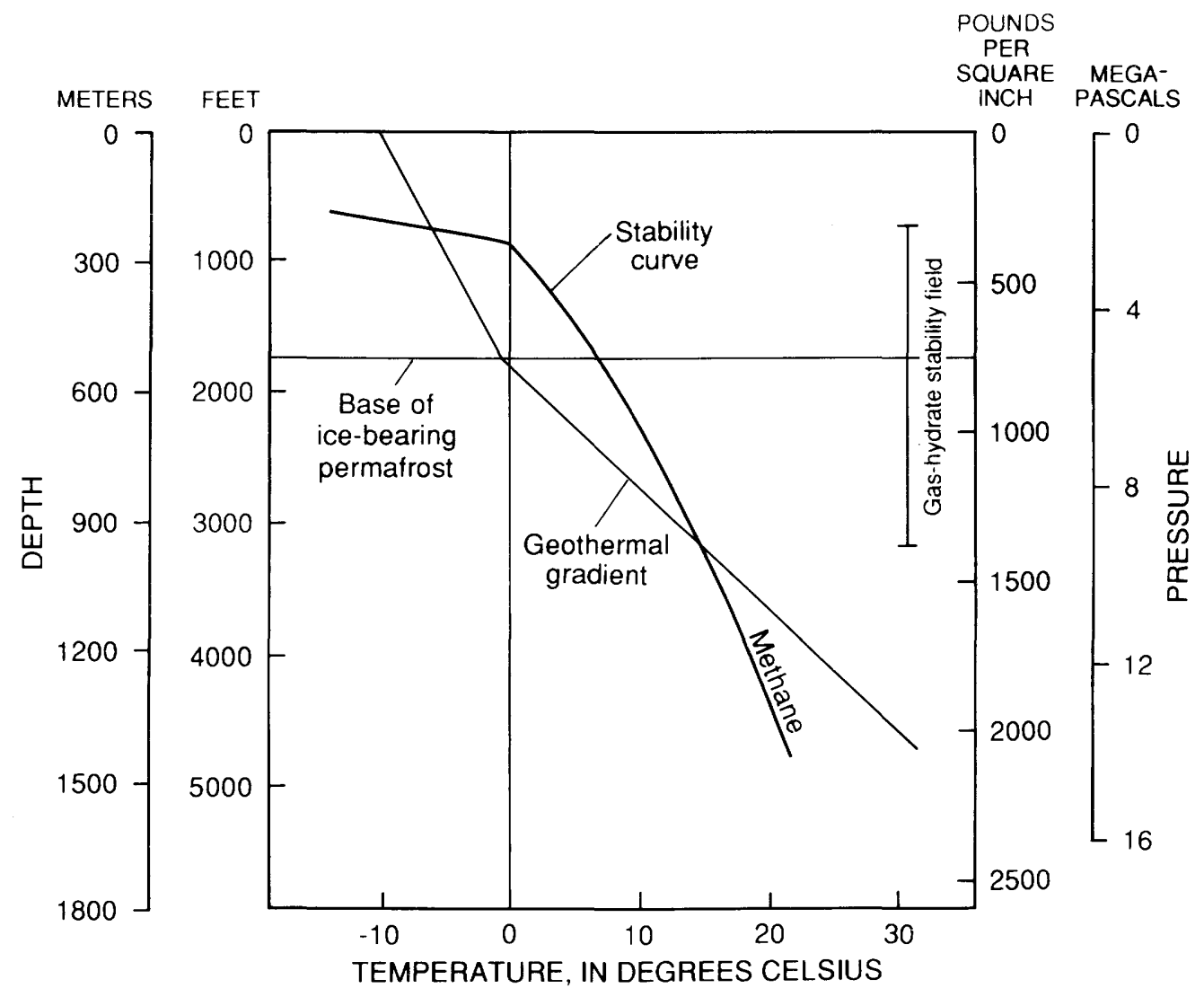

Figure 1. Gas-hydrate phase diagram for Northwest Eileen State-2 well on North Slope of Alaska, showing zone in which gas hydrates may occur. Hydrate is assumed to be composed of pure methane and pure water. Geothermal gradient is $1.9^{\circ} \mathrm{C} / 100 \mathrm{~m}$ above base of ice-bearing permafrost and $3.2^{\circ} \mathrm{C} / 100 \mathrm{~m}$ below it. Location of well shown on figure 2. 
Petroleum geochemical information and interpretation of oil types (Magoon and Claypool, 1981) and oil-source rock correlations (Seifert and others, 1979) indicate that the oil in the Prudhoe Bay-Kuparuk River area is from the same source rocks, the Shublik Formation, Kingak Shale, and to a lesser extent, the (informal) pebble shale unit. In late Early Cretaceous time, these source rocks were mature in the western part of the North Slope area. Maturity progressed eastward toward the Barrow Arch in the Prudhoe Bay area, a structural high during the Early Cretaceous. Oil and gas migrated to the Prudhoe Bay area and accumulated in the Prudhoe Bay, Lisburne, and Endicott oil fields until middle Tertiary time. Sometime during the Tertiary, this trap was tilted to the northeast, and oil apparently migrated up faults at the west end of the Prudhoe Bay oil field into the Kuparuk River and West Sak-Ugnu reservoirs (Carman and Hardwick, 1983). The spatial relations between the major oil accumulations, the inferred gas-hydrate occurrences, and major fault zones are shown on the map in figure 2 and on the cross section in figure 4 .

\section{GAS-HYDRATE OCCURRENCES}

The only confirmed natural-gas-hydrate sample from the North Slope was obtained in 1972 in a core recovered by ARCO and Exxon (reviewed by Collett and Kvenvolden, 1987). The sample was from a depth of 666 $\mathrm{m}$ in the Northwest Eileen State-2 well (fig. 2), located in the Prudhoe Bay oil field. Indirect evidence from drillers and open-hole geophysical well logs strongly suggests the presence of numerous gas-hydrate-bearing layers in the area of the Kuparuk River and Prudhoe Bay oil fields (Collett, 1983; Collett and others, 1988).

We examined 445 North Slope wells for potential gas-hydrate occurrence. Most of the wells are from the Prudhoe Bay-Kuparuk River area; however, we also reviewed all wells from the National Petroleum Reserve in Alaska (NPRA) and most of the exploratory wells to the south and east of Prudhoe Bay. Data used included well logs, well histories, drilling reports, core descriptions, and production tests. This review revealed that gas hydrates occur in at least 39 of the surveyed wells, all from the Prudhoe Bay-Kuparuk River area. The resistivity and acoustic transit-time well logs and the gas chromatograph on the mud log proved to be the most useful tools for identifying suspected in situ gas hydrates.

All of the gas hydrates occur below the base of a siltstone unit that was deposited during a basinwide marine transgression in Eocene time. All of the known and suspected gas hydrates occur in sandstone reservoirs of the Saganavirktok Formation (Brookian sequence).

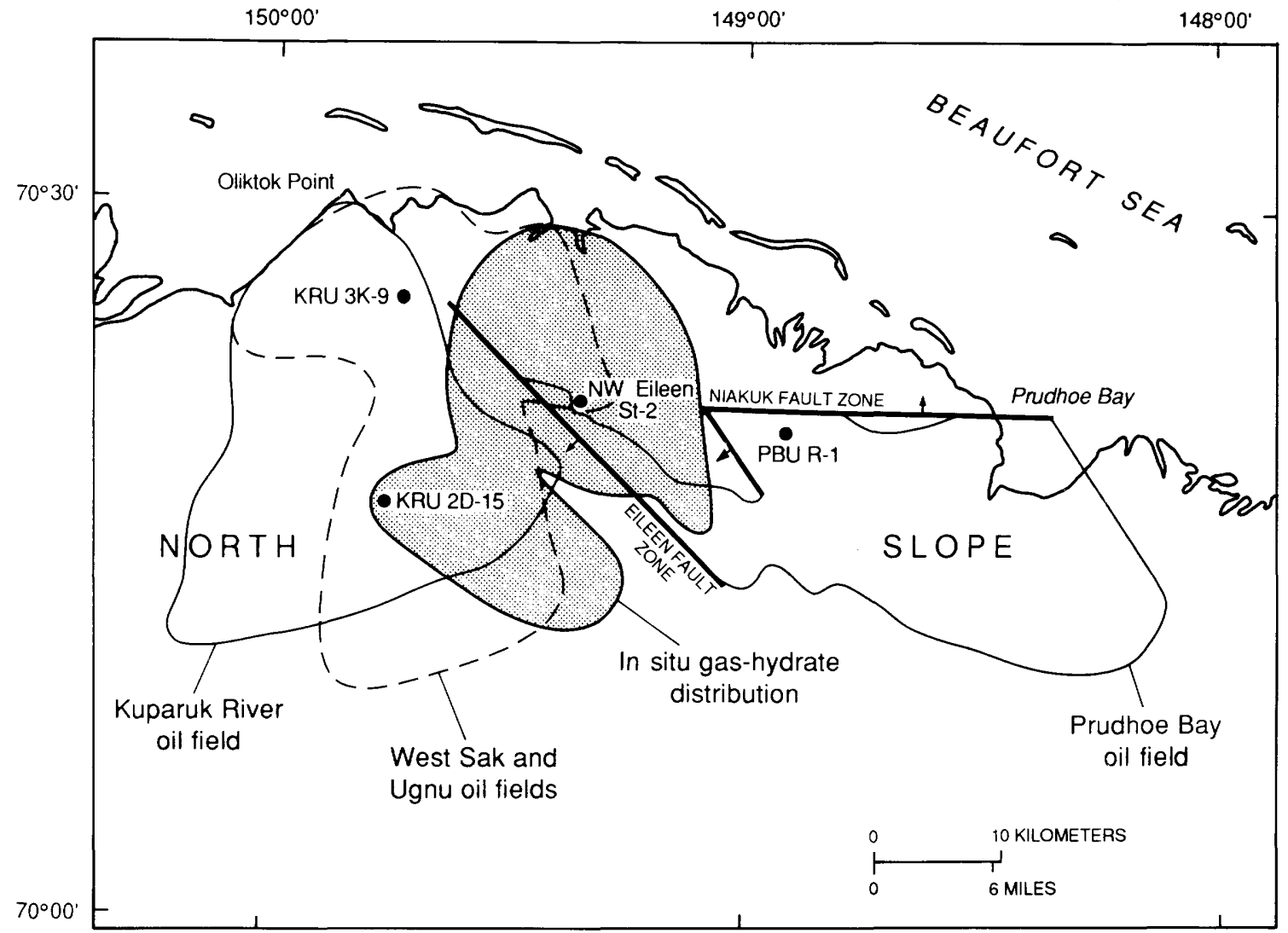

Figure 2. Distribution of in situ gas hydrates and oil occurrences in Prudhoe Bay-Kuparuk River area. West Sak and Ugnu oil fields are shown as a single accumulation, enclosed by a dashed line. Major fault zones are indicated by bold lines; direction of dip shown by arrow. Oil well locations are shown by solid circles. 
These sandstones were likely deposited as point bars and distributary mouth bars in a delta-plain environment (Collett and others, 1988). Most of the gas hydrates occur in six laterally continuous sandstone and conglomerate units and are geographically restricted to the east end of the Kuparuk River oil field and the west end of the Prudhoe Bay oil field (figs. 2, 4). Many wells have multiple gas-hydrate-bearing units, with individual occurrences ranging in thickness from 2 to 28 meters. Most of the gas hydrates occur below the base of ice-bearing permafrost; however, mud logs from wells in the $\mathrm{Ku}$ paruk River oil field suggest that several of the gashydrate-bearing units extend up-dip into the ice-bearing permafrost sequence. A significant volume of oil is contained in one of the gas-hydrate intervals, in both the Kuparuk River area and Prudhoe Bay area. Well logs and drill-cuttings analysis have also revealed the presence of numerous thick coal seams closely associated with several of the gas-hydrate-bearing units.

\section{SOURCE OF THE GAS WITHIN THE IN SITU GAS HYDRATES}

To characterize the source of the gas trapped within the North Slope gas-hydrate occurrences, we reviewed the geochemical data from the cored gas

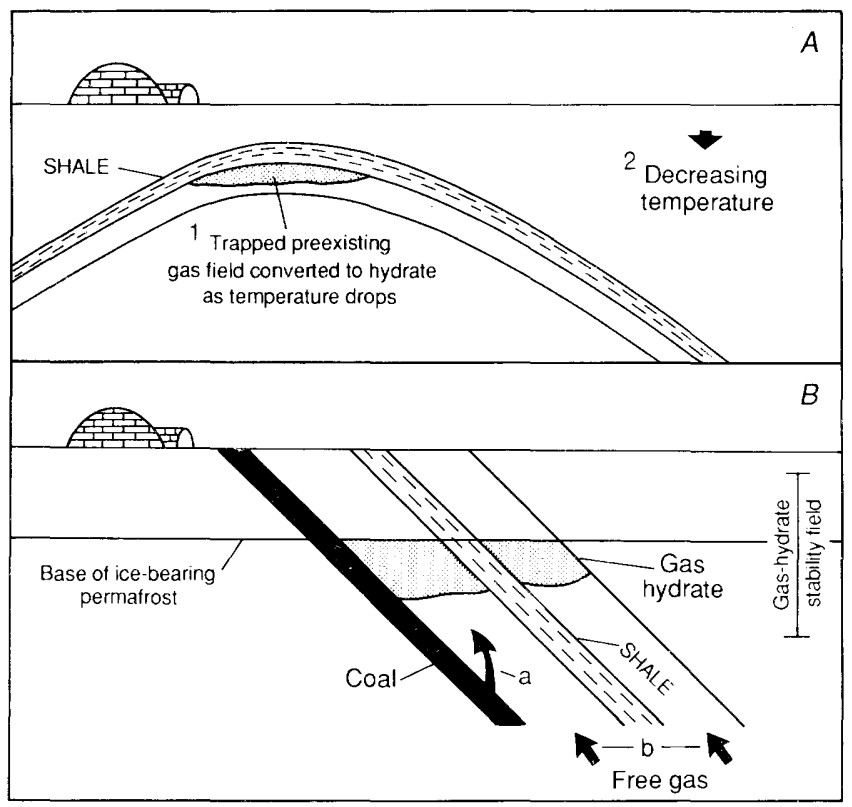

Figure 3. Examples of models of gas-hydrate formation. $A$, Model 1: Conversion of preexisting gas field trapped within anticlinal structure (1) into a gas-hydrate accumulation by a decrease in temperature (2). $B$, Model 2: Formation of gas hydrates within monoclinal porous rock units by migration (arrows) of microbial (a) or thermogenic (b) gas into preexisting pressure-temperature regime in which gas hydrates are stable. hydrate in the Northwest Eileen State-2 well. We also collected and geochemically analyzed drill cuttings from seven wells drilled in the Prudhoe Bay and Kuparuk River oil fields.

Gas analyses of the gas-hydrate-bearing cores from the Northwest Eileen State-2 well indicated that methane is the primary hydrocarbon gas within the cored gas hydrates (reviewed in Collett and others, 1988). Because methane was the only hydrocarbon gas detected in significant amounts, it can be assumed that the $\mathrm{C}_{1} /\left(\mathrm{C}_{2}+\mathrm{C}_{3}\right)$ ratio of gases from the gas-hydrate cores is much greater than 1,000, suggesting the presence of mainly microbial gas. No isotopic data are available, however, to support this interpretation of source.

In the Kuparuk River Unit 2D-15 production well, one of the seven wells sampled for this project, we infer that a 30-m-thick interval contains gas hydrates (Collett and others, 1987). The occurrence of gas hydrates is suggested by the release of unusually large amounts of methane as indicated on the mud log and an increase in transit-time velocity and electrical resistivity on the well logs. Headspace-gas analysis (table 1) of canned drill cuttings from the Kuparuk River 2D-15 well reveal methane to propane-plus-ethane ratios $\left(\mathrm{C}_{1} /\left[\mathrm{C}_{2}+\mathrm{C}_{3}\right]\right)$ typical of microbial gas, with values ranging from 3,300 to 14,500 . In contrast, the carbon isotopic composition of the methane indicates the presence of thermogenic gas with ${ }^{13} \mathrm{C} /{ }^{12} \mathrm{C}$ isotope values of approximately -49 permil. Stable-carbon isotopic compositions of -50 permil and heavier suggest that the gas was thermally generated. Vitrinite reflectance $\left(R_{o}\right)$ measurements of about 0.4 percent show that the gas-hydrate-bearing sediments have never been subjected to temperatures within the thermogenic window. Thus, the thermogenic gas must have migrated from greater depths, and the gas hydrate may contain a mixture of microbial and thermogenic gases.

\section{NORTH SLOPE GAS-HYDRATE MODEL}

In developing a model for the origin of gas hydrates on the North Slope of Alaska, we must account for the following observations pertaining to the distribution of the gas hydrates: (1) All the gas hydrates found to date are near the eastern boundary of the Kuparuk River oil field and extend into the west end of the Prudhoe Bay oil field, an area cut by faults extending deep into the stratigraphic section (fig. 2); (2) gas hydrates are present in a series of sandstone units that dip gently to the northeast; (3) all the gas hydrates are below a relatively impermeable marine siltstone sequence; (4) gas hydrates commonly occur near coal sequences; (5) oil and tar are found within one inferred gas-hydrate-bearing interval; and (6) methane is the prominent gas in the near-surface sediments $(0-1,500 \mathrm{~m})$. 
Carman and Hardwick (1983) postulated that oil within the West Sak and Ugnu sands migrated along faults from the underlying Prudhoe Bay oil field. If this theory is correct, free gas from within the Sadlerochit reservoir and dissolved gas associated with oils would also have migrated into the overlying sedimentary rocks. As shown in figures 2 and 4, most of the gas hydrates and shallow heavy oils occur either up-dip from or near the Eileen fault zone. This fault zone may have acted as a conduit for free-gas and oil migration from deeper hydrocarbon accumulations. The gas within the gas cap of the Prudhoe Bay oil field is composed primarily of methane ( 75 to 85 percent) along with small quantities of ethane ( 5 to 7 percent) and propane ( 2 to 4 percent). If gas within the near-surface sediments migrated from deeper structures, these shallow gases should have geochemical constituents similar to those of the deep gases. However, no significant amounts of ethane or propane were detected within the stratigraphic interval of gashydrate stability. The depletion of heavier hydrocarbons such as ethane and propane from gases by stripping during migration has been suggested by Schoell (1983) and Jenden and Kaplan (1986) to explain natural gases containing thermogenic methane but only minor amounts of heavier hydrocarbons. The thermogenic component of the gas within the stratigraphic interval of gas-hydrate stability may have been stripped of most of its heavier hydrocarbons. Such a process could account for the molecular and isotopic compositions observed. The presence of thermogenic gas, as indicated from the carbon isotopic analysis of drill cuttings, supports the theory that gas has migrated into these units from the underlying accumulations, possibly along the Eileen or related faults. The presence of oil within one of the gas-hydrate-bearing units supports the theory that oil and gas must have migrated from the underlying Prudhoe Bay or Kuparuk River oil fields. A second geochemical feature of gas hydrates that may be important is the relation between coal and gas. Gas hydrates are known to occur in close proximity to several thick coal sequences in the Kuparuk River area. Microbial alteration of the organic matter in these coals may have supplied a significant volume of methane to the gas hydrates.

To describe the history of gas-hydrate formation, we have adapted a generalized cross section from Carman and Hardwick (1983; fig. 4). As gas moved up the Eileen fault zone and encountered relatively porous and permeable northeast-dipping sandstone units, some of the gas may have been rechanneled up-dip along these beds. The up-dip migrating gas may have collected in

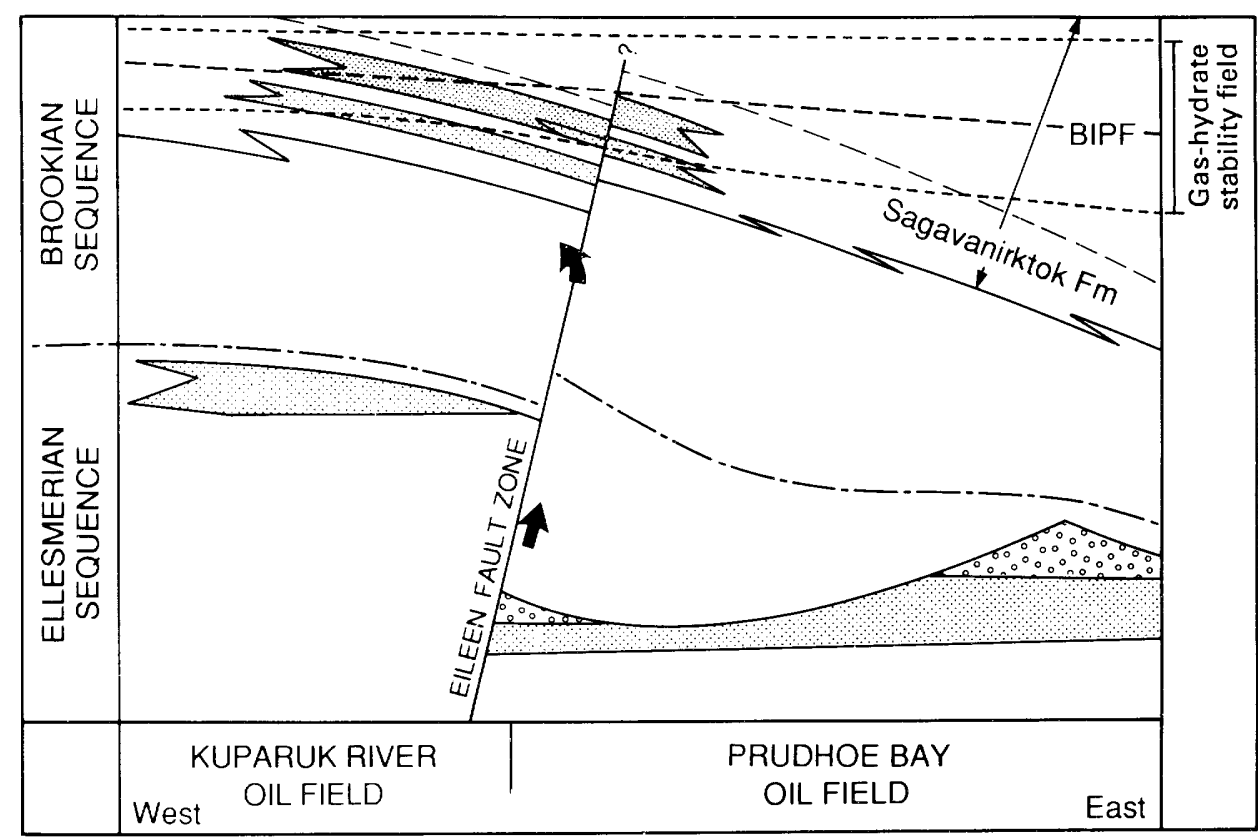

EXPLANATION

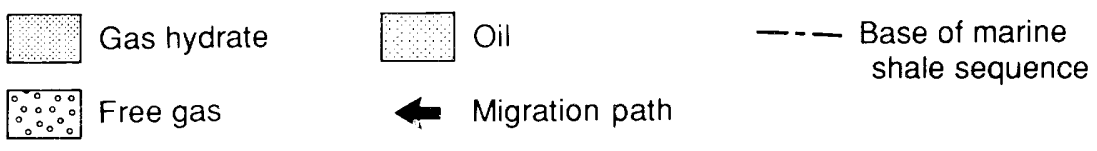

Figure 4. Schematic west to east cross section through Prudhoe Bay-Kuparuk River area illustrating possible gas migration paths and spatial relations between gas hydrates, gas, oil, Eileen fault zone, base of ice-bearing permafrost (BIPF), and gas-hydrate stability field (adapted from Carman and Hardwick, 1983, fig. 13). 
Table 1. $\mathrm{C}_{1} /\left(\mathrm{C}_{2}+\mathrm{C}_{3}\right)$ ratios and methane ${ }^{13} \mathrm{C} /{ }^{12} \mathrm{C}$ isotopic compositions for the Kuparuk River Unit 2D-15 well

\begin{tabular}{|c|c|c|}
\hline $\begin{array}{l}\text { Sample Depth } \\
\text { (ft) }\end{array}$ & $\begin{array}{l}\mathrm{C}_{1} /\left(\mathrm{C}_{2}+\mathrm{C}_{3}\right) \\
\text { (ratio) }\end{array}$ & $\begin{array}{l}{ }^{13} \mathrm{C}^{12} \mathrm{C} \\
\text { (permil) }\end{array}$ \\
\hline 270 & 28 & - \\
\hline 360 & 81 & - \\
\hline 450 & 26 & - \\
\hline 540 & 322 & - \\
\hline 630 & 609 & - \\
\hline 720 & 383 & - \\
\hline 810 & 481 & - \\
\hline 900 & 676 & - \\
\hline 990 & 815 & - \\
\hline 1,050 & 1,287 & - \\
\hline 1,110 & 2,479 & -39.3 \\
\hline 1,170 & 3,630 & -49.6 \\
\hline 1,230 & 4,222 & -48.9 \\
\hline 1,290 & 5,935 & -50.0 \\
\hline 1,350 & 5,885 & -49.1 \\
\hline 1,470 & 14,579 & -46.6 \\
\hline 1,530 & 12,733 & - \\
\hline 1,650 & 7,060 & -41.2 \\
\hline 1,770 & 4,456 & - \\
\hline 1,830 & 704 & - \\
\hline 1,890 & 4,926 & - \\
\hline 1,950 & 3,588 & - \\
\hline 2,160 & 24 & - \\
\hline 2,220 & 61 & - \\
\hline 2,280 & 1,415 & - \\
\hline 2,400 & 13 & - \\
\hline 2,500 & 3,381 & -38.6 \\
\hline 2,560 & 322 & - \\
\hline 2,680 & 838 & - \\
\hline 2,740 & 1,352 & - \\
\hline 2,860 & 826 & - \\
\hline 2,920 & 19 & - \\
\hline 2,980 & 9 & - \\
\hline 3,040 & 5 & - \\
\hline 3,100 & 6 & - \\
\hline 3,160 & 23 & - \\
\hline
\end{tabular}

1Relative to the PDB standard.

structural or stratigraphic traps where subsequent temperature changes deepened the permafrost sequence and converted the trapped gas into hydrate. Conversely, the up-dip migrating gas may have converted to gas hydrate upon entering the pressure-temperature regime of gashydrate stability, thus forming its own trap. Because so little is known about the history of temperatures on the North Slope and the presence of traps for free gas in this area, either of these scenarios is plausible. However, we speculate that gas hydrates presently occur more than $160 \mathrm{~m}$ above the base of ice-bearing permafrost, which is assumed to be impermeable (Jamison and others, 1980; Collett and others, 1988). Therefore, when gas migrated into these upper horizons, the base of the ice-bearing permafrost must have been at least $160 \mathrm{~m}$ shallower than today.
Since the onset of gas migration into these nearsurface horizons (middle Tertiary time), temperatures have fluctuated significantly. Regional temperature changes during the last 2 to 3 million years have been great enough to repeatedly thicken and thin the zone of gas-hydrate stability; however, the magnitude of these changes is not known. It is known that a surface water body of depth sufficient to prevent complete freezing inhibits or prevents the formation of permafrost (Lachenbruch, 1957). Therefore, we must consider the paleopositions of the coastline of the Arctic Ocean. Certainly more work is needed to establish the history of subsurface temperatures on the North Slope.

An additional observation which strengthens the idea that migrating gas was involved with gas-hydrate formation is that all of the gas hydrates occur regionally below a marine siltstone sequence. This relatively impermeable rock sequence may act as a barrier to vertical gas migration, thus controlling the distribution of gas hydrate. Such a barrier may explain why no gas hydrates are present in the eastern part of the Prudhoe Bay oil field. Because of the regional northeastward dip, all potential gas-hydrate-bearing units in the Prudhoe Bay area occur below the zone of gas-hydrate stability. Thus, a limited supply of gas to the zone of gas-hydrate stability prevents hydrate formation.

\section{CONCLUSION}

Given our present understanding, two possible explanations for the origin of the gas hydrates in the Prudhoe Bay-Kuparuk River area are recognized. (1) Thermogenic solution gas and free gas from reservoirs of the Prudhoe Bay oil field migrate upward along the Eileen and other fault zones into the overlying shallow sedimentary rocks. In these rocks, in situ microbial gas mixes with the thermogenic gas, causing total gas concentrations to reach amounts that trigger gas-hydrate formation within the zone of gas-hydrate stability. (2) Concentration of in situ and migrated gas in shallow traps which initially were outside the zone of gas-hydrate stability, but moved into that zone in response, for example, to climate cooling, causes gas hydrates to form both within and beneath permafrost.

\section{ACKNOWLEDGMENTS}

This study was funded by the U.S. Department of Energy under interagency agreement No. DEAI21-83MC20422.

\section{REFERENCES CITED}

Bily, C., and Dick, J.W.L., 1974, Natural occurring gas hydrates in the Mackenzie Delta, Northwest Territories: Bulletin of Canadian Petroleum Geology, v. 22, no. 3, p. 340-352. 
Carman, G.J., and Hardwick, Peter, 1983, Geology and regional setting of the Kuparuk oil field, Alaska: American Association of Petroleum Geologists Bulletin, v. 67, no. 6, p. 1014-1031.

Collett, T.S., 1983, Detection and evaluation of natural gas hydrates from well logs, Prudhoe Bay, Alaska: Fairbanks, University of Alaska, Masters Thesis, $77 \mathrm{p}$.

Collett, T.S., Bird, K.J., Kvenvolden, K.A., and Magoon, L.B., 1988, Geologic interrelations relative to gas hydrates within the North Slope of Alaska: U.S. Geological Survey Open-File Report 88-389, 150 p.

Collett, T.S., and Kvenvolden, K.A., 1987, Evidence of naturally occurring gas hydrates on the North Slope of Alaska: U.S. Geological Survey Open-File Report 87-255, 8 p.

Collett, T.S., Kvenvolden, K.A., Magoon, L.B., and Bird, K.J., 1987 , Geochemical and geologic controls on the inferred occurrence of natural gas hydrate in the Kuparuk 2D-15 well, North Slope, Alaska, in Hamilton, T.D., and Galloway, J.P., eds., Geologic studies in Alaska by the U.S. Geological Survey during 1986: U.S. Geological Survey Circular 998, p. 24-26.

Galate, J.W., and Goodman, M.A., 1982, Review and evaluation of evidence of in-situ gas hydrates in the National Petroleum Reserve in Alaska: U.S. Geological Survey unpublished report, Contract No. 14-08-000119148, 102 p.

Grantz, Arthur, Holmes, M.L., and Kososki, B.A., 1975, Geologic framework of the Alaskan continental terrace in the Chukchi and Beaufort Seas, in Yorath, Parker, and Glass, eds., Canada's continental margins and offshore petroleum exploration: Canadian Society of Petroleum Geologists Memoir 4, p. 669-700.

Hammerschmidt, E.D., 1934, Formation of gas hydrates in natural gas transmission lines: Industrial and Engineering Chemistry, v. 26, p. 851-855.

Jamison, H.C., Brockett, L.D., and McIntosh, R.A., 1980, Prudhoe Bay-A 10 year perspective, in Halbouty, M.T., ed., Giant oil and gas fields of the decade 1968-1978: American Association of Petroleum Geologists Memoir 30, p. 289-314.

Jenden, P.D., and Kaplan, I.R., 1986, Comparison of microbial gases from the Middle American Trench and Scripps Submarine Canyon-Implications for the origin of natural gas: Applied Geochemistry, v. 1, p. 631-646.
Katz, D.L., 1971, Depths to which frozen gas fields (gas hydrates) may be expected: Journal of Petroleum Technology, v. 23, p. 419-423.

Kvenvolden, K.A., and McMenamin, M.A., 1980, Hydrates of natural gas-A review of their geologic occurrence: U.S. Geological Survey Circular 825, 11 p.

Lachenbruch, A.H., 1957, Thermal effects of ocean on permafrost: Geological Society of America Bulletin, v. 68, no. 11, p. 1515-1529.

Lerand, M., 1973, Beaufort Sea, in McCrossan, R.G., ed., Future petroleum provinces of Canada-Their geology and potential: Canadian Society of Petroleum Geologists Memoir 1, p. 315-386.

Magoon, L.B., and Claypool, G.E., 1981, Two oil types on the North Slope of Alaska-Implications for exploration: American Association of Petroleum Geologists Bulletin, v. 65 , no. 4 , p. $644-652$.

Makogon, Y.F., 1981, Hydrates of natural gas: Tulsa, Penn Well Publishing Company, 237 p.

Potential Gas Agency, 1981, Gas hydrates, in Potential supply of natural gas in the United States (as of December 31, 1980): Golden, Colorado School of Mines, p. 76-89.

Pratt, R.M., 1979, Gas hydrate evaluation and recommendations, National Petroleum Reserve, Alaska: U.S. Geological Survey Special Report TC-7916, 27 p.

Schoell, Martin, 1983, Genetic characterization of natural gases: American Association of Petroleum Geologists Bulletin, v. 67 , no. 12 , p. 2225-2238.

Seifert, W.K., Moldowan, J.M., and Jones, J.W., 1979, Application of biological chemistry to petroleum exploration: 10th World Petroleum Congress, p. 425-440.

Werner, M.R., 1987, Tertiary and Upper Cretaceous heavy oil sands, Kuparuk River area, Alaskan North Slope, in Tailleur, I.L., and Weimer, Paul, eds., Alaskan North Slope geology: Bakersfield, California, Pacific Section, Society of Economic Paleontologists and Mineralogists and the Alaska Geological Society, Book 50, v. 1, 109-118.

\section{Reviewers:}

L.A. Beyer

T.R. Bruns 


\title{
Age and Chemical Composition of Proterozoic Intrusive Rocks at Mount Angayukaqsraq, Western Brooks Range, Alaska
}

\author{
By Susan M. Karl, John N. Aleinikoff, Closey F. Dickey, and John T. Dillon
}

\begin{abstract}
The intrusive rocks in the metamorphic complex near Mount Angayukaqsraq in the northeastern Baird Mountains quadrangle, western Brooks Range, Alaska, consist mainly of cumulate leucogabbro and gabbro, with subordinate younger granodiorite and alkali feldspar granite. Both the gabbroic and granitic rocks are massive, but locally have foliated zones attributed to high strain. A variety of relict igneous textures are preserved, but most primary minerals have been replaced by products of alteration or metamorphism. The gabbroic rocks have high alumina contents. The granitic rocks are highly evolved $\left(\mathrm{SiO}_{2}\right.$ greater than 75 weight percent; $\mathrm{Rb} / \mathrm{Sr}$ ratios 6.1 to 22.0 ) and mildly peraluminous, and show trace-element signatures typical of granites formed in a within-plate tectonic setting. Both the gabbros and granites show similar patterns of light/heavy rareearth-element fractionation, with only minor heavy rare-earthelement depletion, suggesting that both were derived from a similar undepleted source.

Uranium-lead zircon dating of three granitoids from the gabbro-granite intrusive bodies in the metamorphic complex at Mount Angayukaqsraq suggests that igneous crystallization occurred at $750 \pm 6 \mathrm{Ma}$. This confirms earlier interpretations of a Late Proterozoic age for these rocks and provides a likely upper limit for the age of amphibolite-facies metamorphism of the country rocks. Deformation and metamorphic minerals in the igneous rocks are attributed to upper Mesozoic Brookian blueschist/greenschist-facies metamorphism, which overprints the amphibolite-facies metamorphism of the country rocks.
\end{abstract}

\section{INTRODUCTION}

The intrusive rocks near Mount Angayukaqsraq in the Baird Mountains quadrangle in the western Brooks Range were briefly described by Mayfield and others (1982). This report is the first detailed description of these rocks. A companion paper (Till, this volume) presents the first detailed description of the associated metamorphic rocks.

Gabbroic and granitic rocks compose the intrusive rocks in the metamorphic complex at Mount Angayukaqsraq (fig. 1). The surrounding metasedimentary and metavolcanic country rocks have been metamorphosed to amphibolite facies and have yielded a range of $\mathrm{K}-\mathrm{Ar}$ and $\mathrm{Rb}-\mathrm{Sr}$ mineral (cooling) ages (Turner and others, 1979; Armstrong and others, 1986), suggesting that metamorphism occurred in a Late Proterozoic thermal event. These are the oldest known metamorphic rocks in the Brooks Range. The age of the intrusive rocks provides important constraints on the minimum age of the sedimentary host rocks and on the timing of Proterozoic metamorphism. The $750 \pm 6-\mathrm{Ma} \mathrm{U}-\mathrm{Pb}$ zircon age reported in this study supersedes the preliminary $820 \pm 30-\mathrm{Ma}$ age reported by Dillon and others (1987), for which analytical data were not published and cannot be recovered.

\section{REGIONAL GEOLOGIC SETTING}

The metamorphic complex at Mount Angayukaqsraq is located near the western end of the Brooks Range fold and thrust belt (fig. 1). It is part of an antiformal duplex that represents the westernmost exposure of the structural core of the Brooks Range. To the south and west, this antiformal structure plunges beneath thrust sheets of compositionally diverse schist and pelitic schist constituting the schist belt. To the west thrust sheets composed of clastic rocks of the Endicott Group and carbonate rocks of the Baird Group structurally overlie the schist belt rocks, and to the north the Endicott Group rocks overlie the Proterozoic and Paleozoic rocks associated with the metamorphic complex. The stratigraphically oldest rocks of the structural core, including the Proterozoic rocks, extend nearly $800 \mathrm{~km}$ to the east, forming part of the parautochthon (Mayfield and others, 1983), also known as the Hammond terrane (Jones and others, 1984), the Skajit allochthon (Oldow and others, 1987), and the central belt (Till and others, 1988). Mayfield and others (1983) inferred that the basement represented by the parautochthon might also be displaced, and this has been confirmed by recent mapping in the Baird Mountains quadrangle (fig. 2). The Late Proterozoic rocks at Mount Angayukaqsraq are imbricated 
with thrust sheets of lower to middle Paleozoic calcareous, volcanic, and siliceous clastic rocks (fig. 3 ), and the imbricate package is thrust over less deformed and less metamorphosed middle to upper Paleozoic carbonate and clastic rocks.

During the Brookian orogeny, the Proterozoic rocks were deformed in a ductile environment and thrusted northward under conditions transitional to brittle deformation (Till and others, 1988), as indicated by ductile structures that are cut by brittle structures with lineated crossite-bearing surfaces. The timing of the Late Jurassic to Early Cretaceous blueschist-facies metamorphism is constrained by stratigraphic relations (Mayfield and others, 1983) and by 85- to 100-Ma K-Ar mineral (cooling) ages (Turner and others, 1979) from rocks elsewhere in the central belt.

\section{INTRUSIVE ROCKS}

Intrusive rocks in the metamorphic complex at Mount Angayukaqsraq and covering approximately 4 square kilometers are made up of approximately 70 percent gabbro and leucogabbro and 30 percent granodiorite and alkali feldspar granite (Streckeisen, 1976). They consist of one main, dominantly gabbroic, composite body on the peak and west shoulder of Mount Angayukaqsaq and several outlying bodies of granite (fig. 2). The granitic rocks crosscut the gabbroic rocks in several places and are consequently inferred to be the younger of the intrusions. Granitic pegmatite also cuts the gabbro at locality 7 (fig. 2). Both granitic and gabbroic rocks show clearcut intrusive relationships with the country rock, and layered metasedimentary and metavolcanic rocks (some of which are hornfelsed) occur as xenoliths and screens 1 to $20 \mathrm{~m}$ thick within the outcrop area of the intrusive rocks. Dikes of gabbro, granite, aplite, granite pegmatite, and hornblendeplagioclase pegmatite up to several meters thick also intrude the country rocks.

The gabbroic rocks (color index 28 to 60 ) contain clinopyroxene and hornblende, generally replaced by epidote, actinolite and an additional pale-colored amphi-

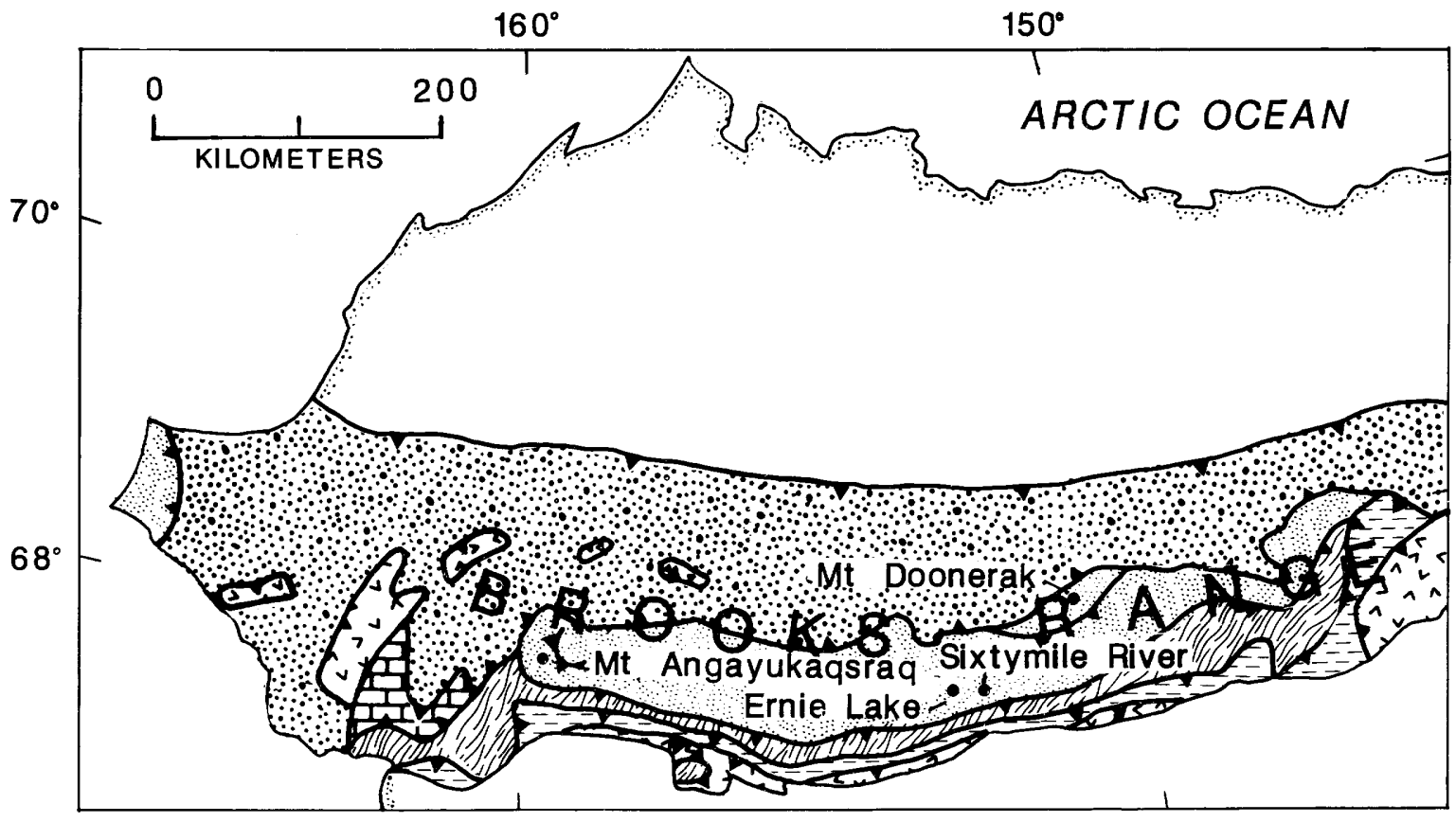

EXPLANATION

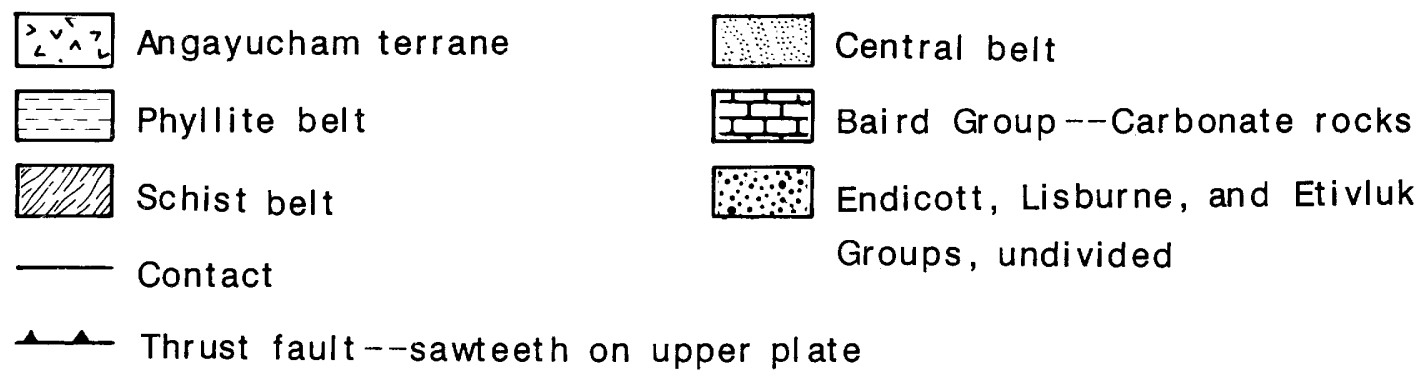

Figure 1. Northern Alaska showing locations of intrusive rocks at Mount Angayukaqsraq, Ernie Lake, and Sixtymile River within central belt of the Brooks Range. 


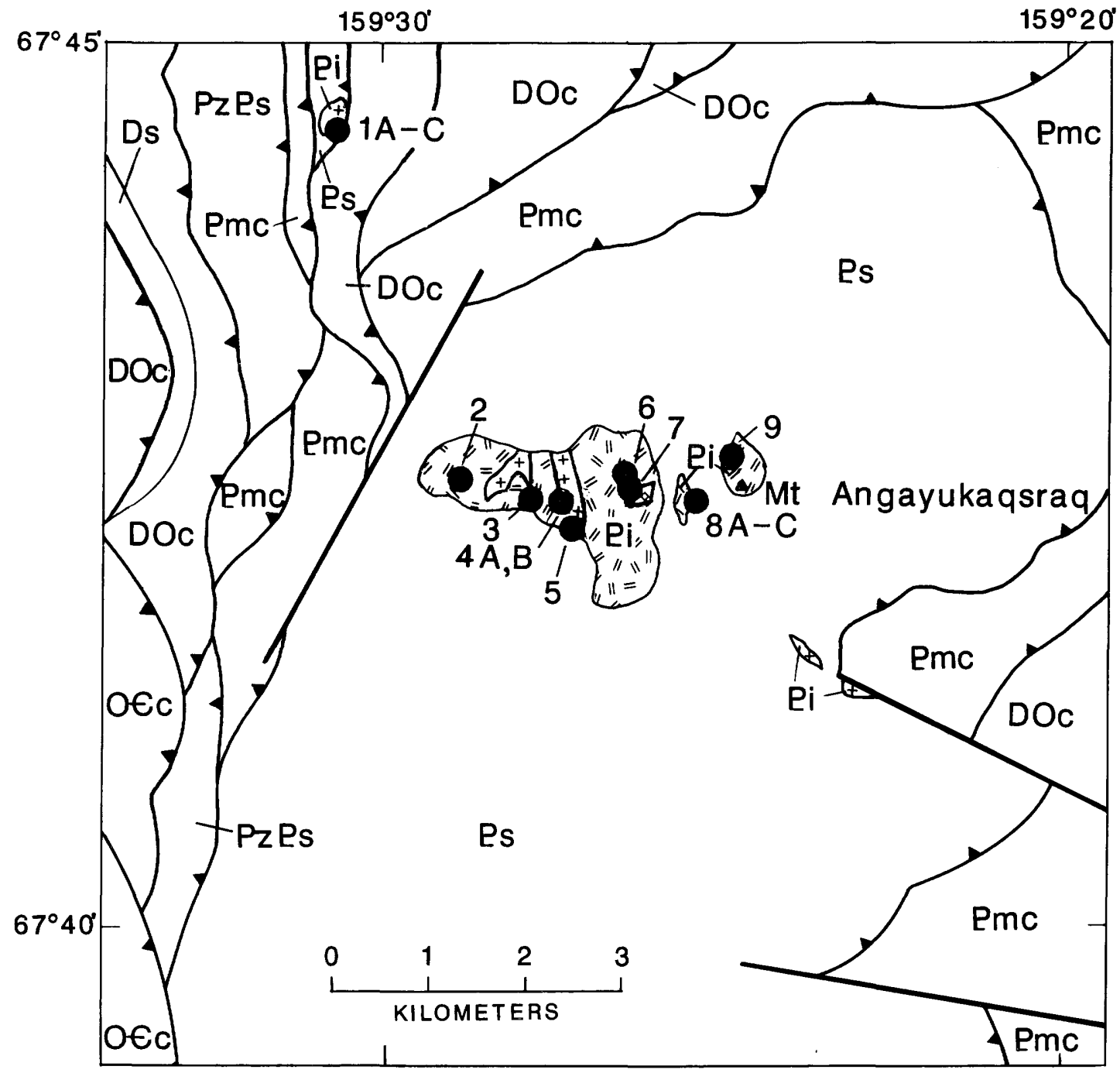

\section{EXPLANATION}

Ds Sedimentary rocks (Devonian)

DOC Carbonate rocks (Devonian and Ordovician)

OEc Carbonate rocks (Ordovician and Cambrian)

PZPS Sedimentary and volcanic rocks (Paleozoic or Proterozoic)

Emc Metabasite and carbonate rocks (Proterozoic)

Ps Metasedimentary rocks (Proterozoic)
$\mathrm{Pi}$ Intrusive rocks (Proterozoic)

$\circ$ Granitic pegmatite

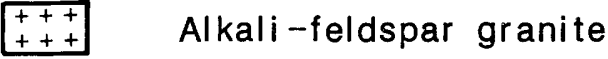

i, Granodiorite

III" Gabbro and leucogabbro

Contact

Fault

L Thrust fault--sawteeth on upper plate Sample locality--numbers refer to tables 1-3

Figure 2. Location of samples analyzed from Proterozoic intrusive rocks at Mount Angayukaqsraq. 
bole, and iron oxides or pyrite. Plagioclase is completely altered to mats of fine-grained clinozoisite. Accessory minerals include rutile and apatite. The granitic rocks contain abundant microcline and perthite, with minor biotite, stilpnomelane, and trace amounts of iron oxides (color index approximately 10). Accessory minerals include metamorphic white mica, zircon, sphene, apatite, and igneous(?) garnet. The metamorphic minerals are attributed to late Mesozoic Brookian metamorphism.

In contrast to the generally well foliated country rocks, the intrusive rocks lack a penetrative fabric. They are typically massive, medium grained, and inequigranular and have relict igneous textures, such as evenly distributed subhedral to euhedral mafic minerals, igneous inclusions showing primary variations in grain size, and zones of differing proportions of mafic and felsic minerals. Igneous textures are locally very inhomogeneous. Gneissic layering is not developed. The igneous rocks are locally well foliated near contacts and in shear zones; in thin section these rocks reveal mortar textures consistent with fabric development in high-strain zones. This style of deformation is similar to that accompanying the Brookian orogeny (Till and others, 1988) and is attributed here (along with crystallization of white mica and stilpnomelane in the granites) to that event. Most dikes within the country rocks parallel compositional layering and foliation, though some zones of amphibolite
1 to $5 \mathrm{~m}$ thick that may originally have been mafic dikes crosscut the layering and foliation. Igneous intrusion thus may have postdated the main phase of Proterozoic deformation, but may have predated amphibolite-facies crystallization.

\section{METAMORPHIC ROCKS}

The metamorphic country rocks at Mount Angayukaqsraq consist of siliceous and pelitic schist, quartzite, metabasite, and calcareous schist. Siliceous schists include quartz-muscovite schist, quartz-feldspar schist, and garnet (dark brown 2-mm porphyroblasts)-chloritemuscovite-quartz schist. The metabasite includes actinolite schist, amphibolite, and garnet (red, up to $1.5-\mathrm{cm}$ porphyroblasts) amphibolite. In addition to the calcareous schist, which consists of quartz, epidote, plagioclase, amphibole, and garnet (Till, this volume), there are minor amounts of garnet-albite-quartz-diopside skarn and coarsely crystalline gray marble. Compositional layering in the country rocks changes on a centimeter to meter scale. Locally the rocks are crenulated and isoclinally folded. The country rocks were metamorphosed to amphibolite facies in the Proterozoic and subsequently locally overprinted by late Mesozoic Brookian blueschistgreenschist-facies metamorphism (Till and others, 1988).

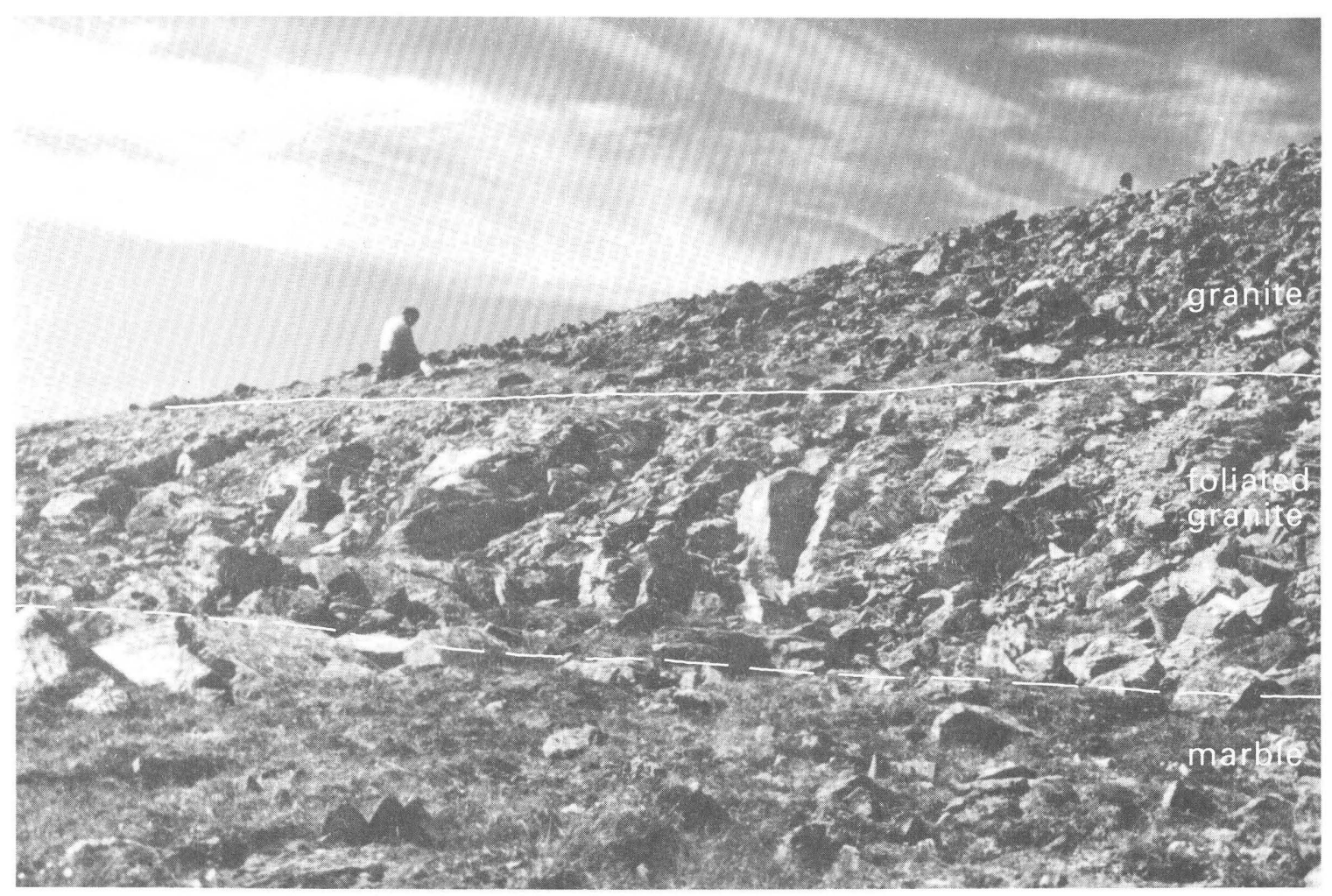

Figure 3. Thrust fault contact of Late Proterozoic granite (fig. 2, loc. 1) and lower to middle Paleozoic marble (DOc, fig. 2). Contact indicated by dashed line. 
Table 1. Normalized chemical analyses (in weight percent) for major oxides for samples from the intrusive rocks at Mount Angayukaqsraq

[Samples analyzed by U.S. Geological Survey, Menlo Park, Calif. Locality numbers refer to figure 2. Rock types are assigned based on counts of approximately 1,000 points on stained rock slabs that were plotted on the compositional fields of Streckeisen (1976)]

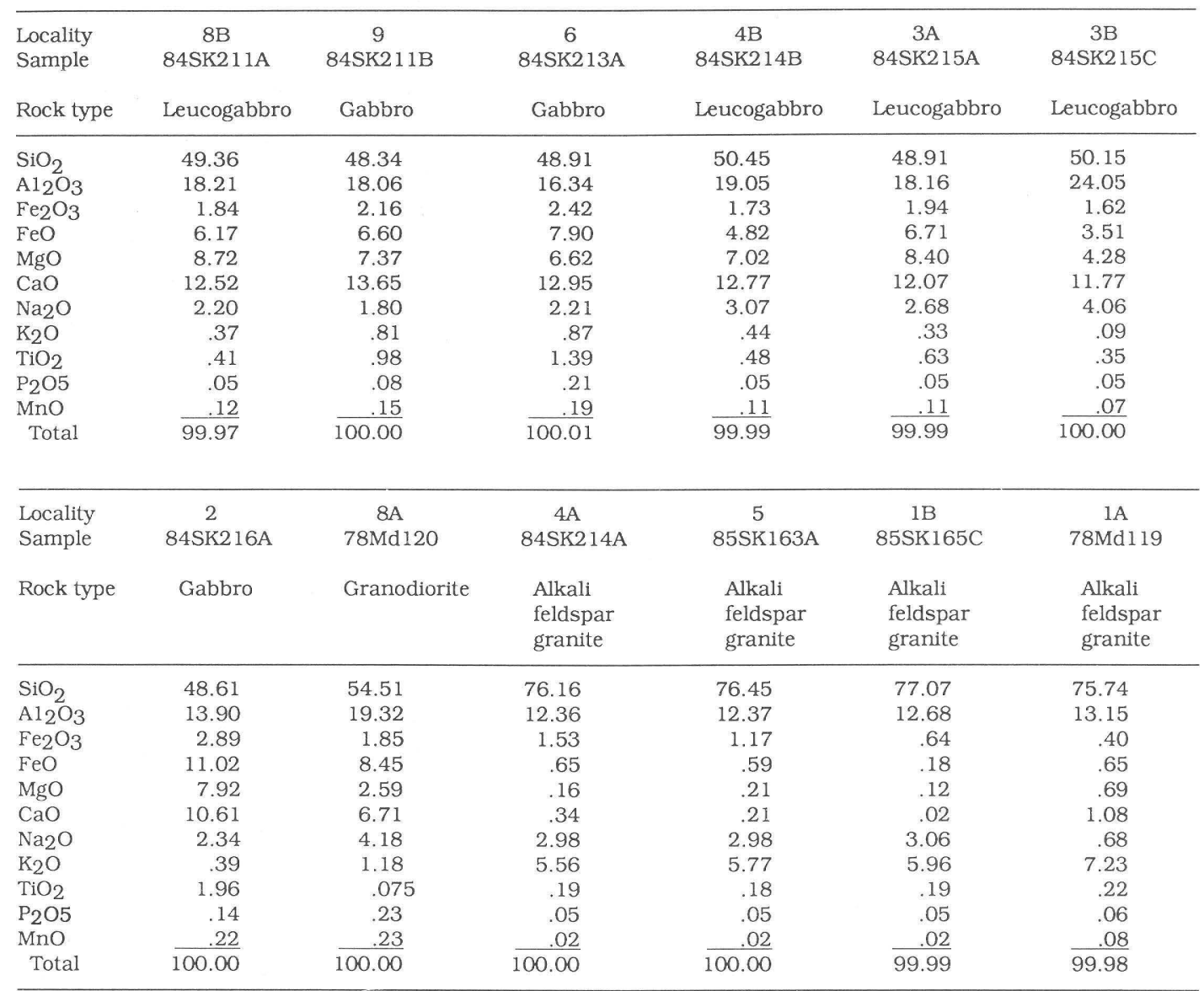

\section{CHEMICAL COMPOSITION}

Major-element chemistry (table 1) shows that the gabbroic rocks have high $\mathrm{Al}_{2} \mathrm{O}_{3}$ contents (up to 24 weight percent). The granites are highly evolved, with greater than 75 weight percent silica, high $\mathrm{Rb} / \mathrm{Sr}$ ratios (6.1 to 22.0), and a mildly peraluminous character.

Rare-earth-element trends (table 2, fig. 4) have low (for the gabbroic rocks) to moderate (for the granitic rocks) total REE abundances. The gabbroic rocks have a small positive europium anomaly, whereas the granites have a moderate negative europium anomaly. Both gabbroic and granitic rocks have similar trends of low fractionation of light/heavy REE; the chondritenormalized $\mathrm{La} / \mathrm{Lu}$ ratio for the granites ranges from 1.52 to 1.73 , and the ratio for the gabbros ranges from 1.34 to 2.16. The REE data are consistent with a cumulate origin involving plagioclase accumulation for the gabbros. The similar slight fractionation of light and heavy REE suggests that both gabbroic and granitic rocks were derived from a similar weakly fractionated source. The fraction- ation is less than that typical of granites derived from arc magmas (see for instance Cullers and Graph, 1984). On $\mathrm{Nb} / \mathrm{Y}$ and $\mathrm{Rb} / \mathrm{Nb} \pm \mathrm{Y}$ diagrams of Pearce and others (1984), the granites plot within the field of within-plate granites (fig. 5).

\section{GEOCHRONOLOGY}

Three samples were dated by the U/Pb zircon method (table 3). Four size fractions of zircon were analyzed from granite sample $85 \mathrm{Dn} 24$, collected about 4 $\mathrm{km}$ northwest of the main body of granite at Mount Angayukaqsraq (loc. 1C, fig. 2). In addition, one size fraction was analyzed from a granodiorite sample $85 \mathrm{Dn} 19$, a recollection of sample $78 \mathrm{Md} 120$ analyzed by J. Dillon, which crosscuts layered metamorphic rocks at Mount Angayukaqsraq (locs. 8A, 8C, fig. 2).

Zircons from the granite are subhedral to euhedral, light to medium brown, and stubby, with lengthto-width ratios $(1 / w)$ of $1 / 1$ to $3 / 1$. Zircons from the 
Table 2. Data for minor and rare earth elements (in parts per million) for samples from the intrusive rocks at Mount Angayukaqsraq

[Samples analyzed by U.S. Geological Survey, Menlo Park, Calif., and Denver, Colo. Locality numbers refer to figure 2]

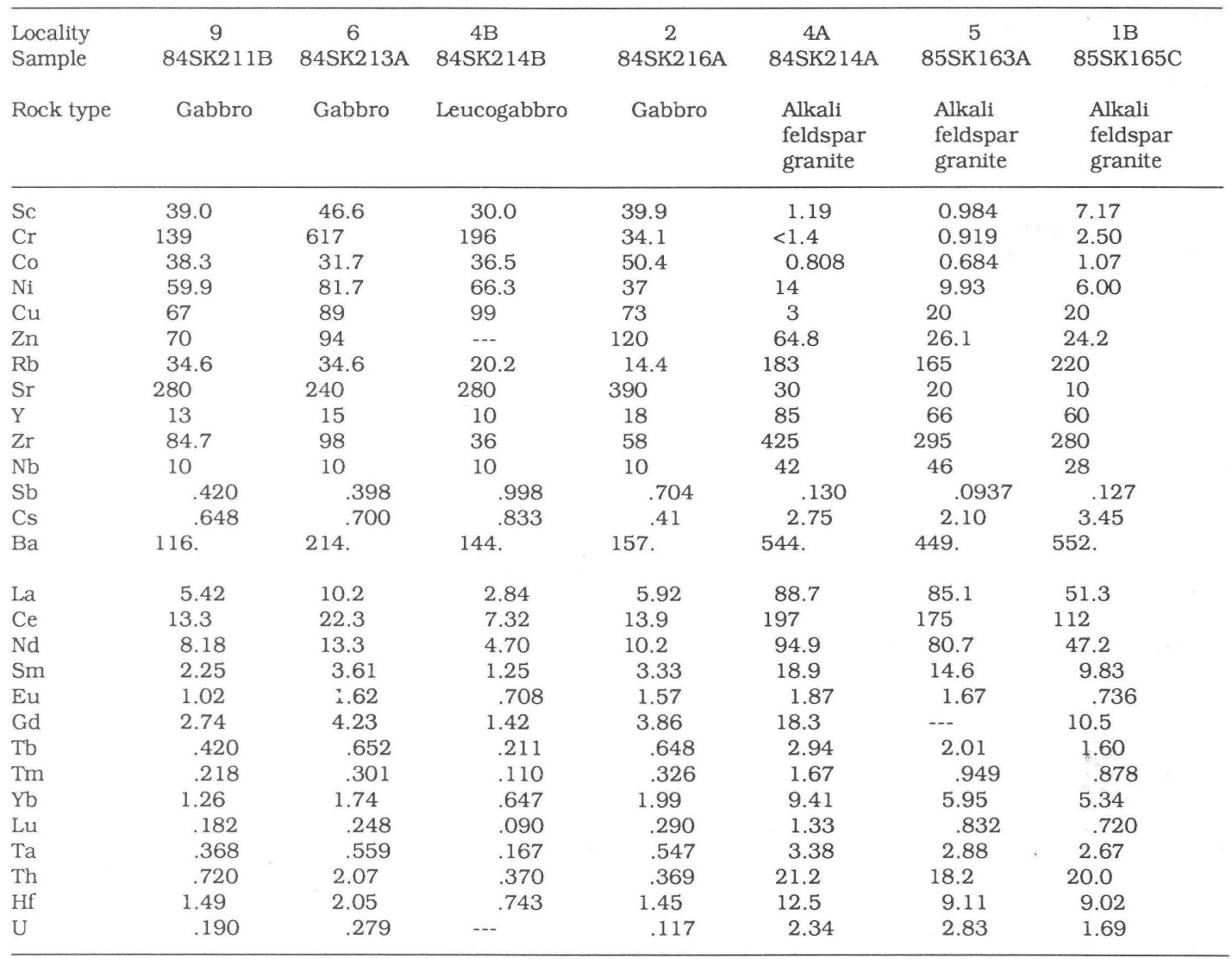

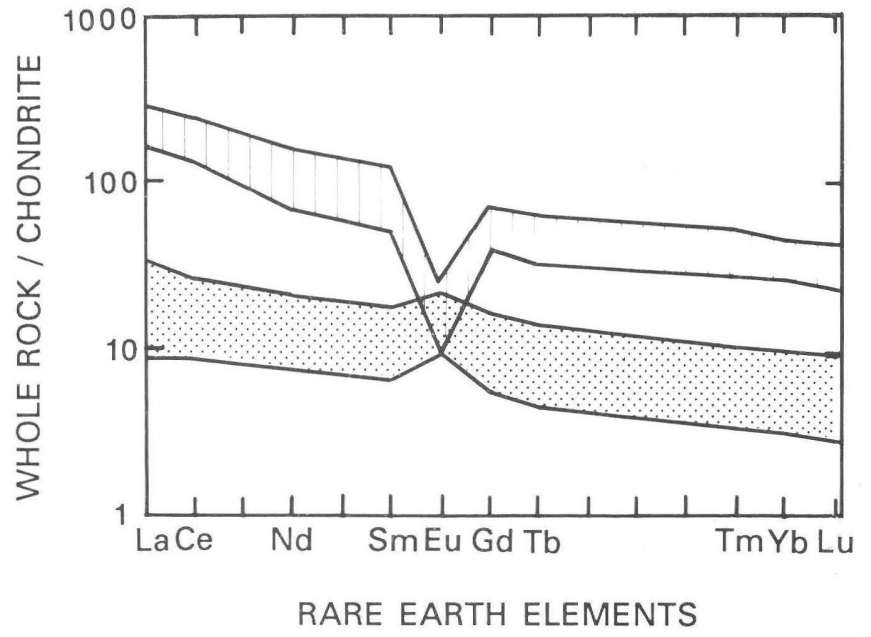

Figure 4. Plot of chondrite-normalized rare-earth-element distribution in igneous rocks from Mount Angayukaqsraq. Ruled pattern represents three granite samples. Stippled pattern represents four gabbro and leucogabbro samples. Sample data listed in table 2. Chondrite data from Anders and Ebihara (1982). granodiorite are subhedral to euhedral and clear to light brown, with $1 / w$ of $2 / 1$ to $5 / 1$. Some terminations of zircons from both samples are rounded, and most faces are pitted. This morphology suggests igneous growth modified by metamorphism.

In the U-Pb data listed in table 3 and plotted on figure 6 , uncertainties are listed for $\mathrm{Pb} / \mathrm{U}$ ratios of samples analyzed at the Branch of Isotope Geology, U.S. Geological Survey, Denver, Colo. Data for zircon fractions in sample $78 \mathrm{Md} 120$ (loc. 8A, fig. 2) were determined by J.T. Dillon at the University of California, Santa Barbara, and uncertainties are assumed to be 0.75 percent. Chemical procedures and mass spectrometry are described in Aleinikoff and others (1986). Zircons from the granodiorite have relatively low uranium concentrations (about 69-253 ppm U) and are only slightly discordant. Zircons from the granite contain much more uranium (about 726-1,321 ppm $\mathrm{U}$ ), and $\mathrm{Pb} / \mathrm{U}$ ages are about 50 percent discordant. ${ }^{207} \mathrm{~Pb} /{ }^{206} \mathrm{~Pb}$ ages for three of four size-fractions from the granodiorite are identical within analytical uncertainty. A best-fit line calculated through these three fractions has intercept ages of about $750 \pm 6$ and $40 \pm 170 \mathrm{Ma}$. Based on zircon morphology, $\mathrm{U}-\mathrm{Pb}$ systematics, and field relations with dated metamorphic rocks, we interpret the upper intercept age as 
the time of intrusion of the granodiorite. The fourth split has a slightly older ${ }^{207} \mathrm{~Pb} /{ }^{206} \mathrm{~Pb}$ age of $764 \mathrm{Ma}$, possibly due to minor inheritance of radiogenic lead.

${ }^{207} \mathrm{~Pb} /{ }^{206} \mathrm{~Pb}$ ages of zircon in the granite range from 639 to $735 \mathrm{Ma}$. Due to scatter and high degree of
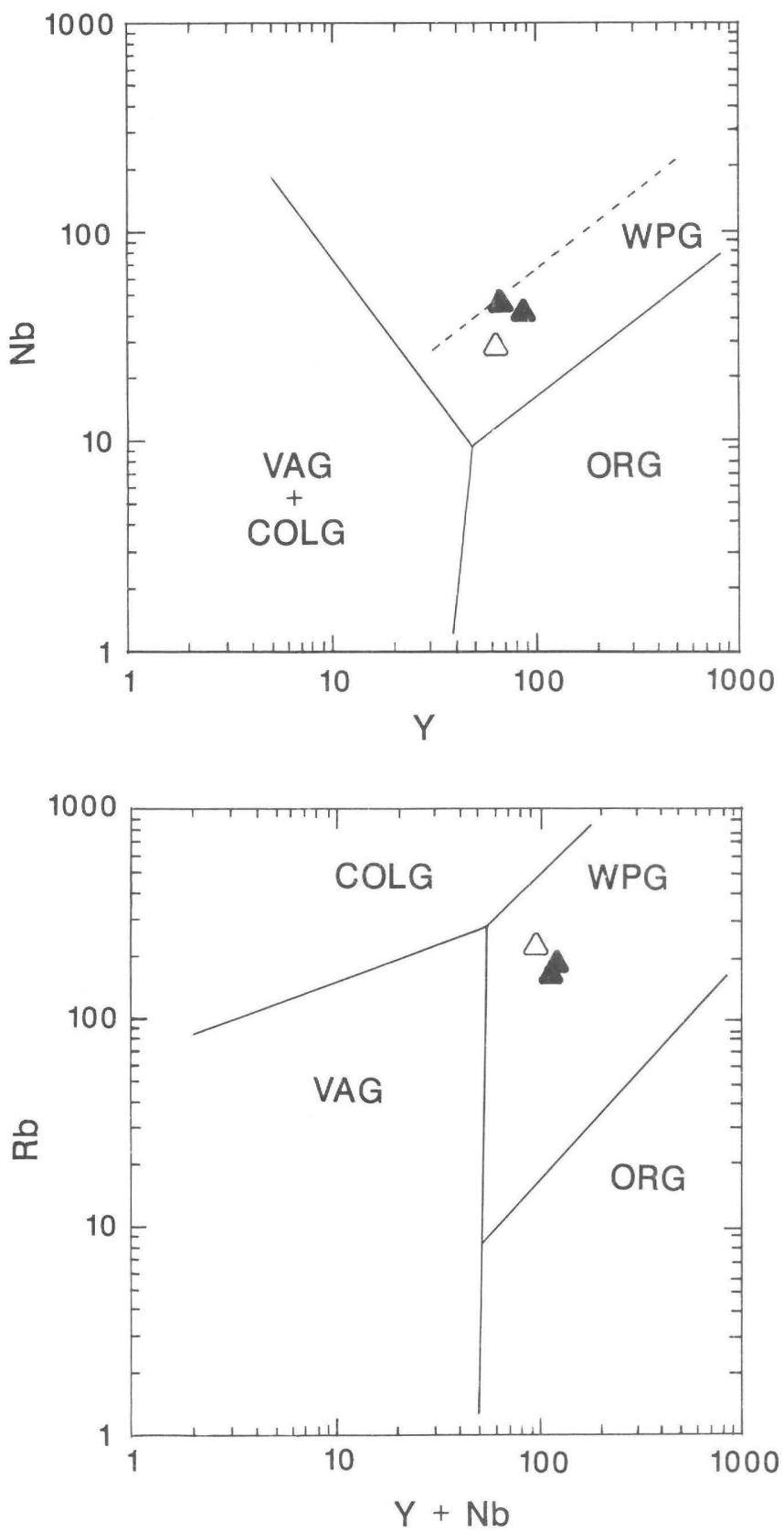

Figure 5. Distribution of geochemical data for granitic rocks at Mount Angayukaqsraq for $\mathrm{Nb}$ versus $\mathrm{Y}$ and $\mathrm{Rb}$ versus $\mathrm{Y}+\mathrm{Nb}$ on discrimination diagrams of Pearce and others (1984). Fields indicated are for syncollision (COLG), volcanic arc (VAG), within-plate (WPG), and ocean ridge (ORG) granites. Dashed line represents upper compositional boundary for ORG from anomalous ridge segments. Element content in parts per million. Closed triangles represent granite samples from Mount Angayukaqsraq and open triangle represents granite sample from the body 4 to $5 \mathrm{~km}$ to the northwest (fig. 2, locs. 1A-C). discordance, we regard the ${ }^{207} \mathrm{~Pb} /{ }^{206} \mathrm{~Pb}$ age of $735 \mathrm{Ma}$ in the $(-325+400) \mathrm{NM}$ fraction, which has the lowest $\mathrm{U}$ contents in sample 85Dn24 (table 3), as a minimum age of growth of the zircons. The regression plotted in figure 6 , calculated for the granodiorite, passes through the data array for the granite. We suggest that the upper intercept age of the granodiorite is probably also the time of intrusion of the granite at Mount Angayukaqsraq. Because a similar granite (locs. 4A, 4B, and 5, fig. 2) to the granite at localities $1 \mathrm{~A}-\mathrm{C}$ (fig. 2) intrudes the gabbro at Mount Angayukaqsraq, this age is also considered to be a minimum age for the gabbroic intrusive rocks. With a crystallization age of about $750 \mathrm{Ma}$ for the granitic rocks, the lower intercept age would be about $70 \mathrm{Ma}$, suggesting Cretaceous episodic lead loss. As no Cretaceous plutons are known in the area, the scatter of sample 85Dn24 (loc. 1C, fig. 2) data may be due to the effects of accumulated radiation damage to the crystal lattice of the U-rich zircons in this sample or to opensystem behavior accompanying heterogeneous deformation and localized fluid circulation during Cretaceous Brookian deformation and metamorphism. However, the possibility of two $\mathrm{Pb}$-loss events, perhaps one in the Mesozoic and one more recently, cannot be ruled out.

\section{DISCUSSION}

The 750 \pm 6-Ma intrusive age for the granite and granodiorite at Mount Angayukaqsraq provides important constraints on the timing of Proterozoic metamorphism in the Brooks Range. Field relations described above suggest that amphibolite-facies metamorphism overprinted mafic dikes of uncertain relation to the intrusive complex, but that the main phase of Proterozoic deformation preceded intrusion. This could suggest that emplacement of the intrusive rocks occurred late during metamorphism or that there were two periods of Proterozoic amphibolite-facies metamorphism, the earliest a regional event (Till and others, 1988; Till, this volume) and the later perhaps a local event related to igneous intrusion. In the case of a single Proterozoic amphibolitefacies event, the $750 \pm 6-\mathrm{Ma}$ zircon age would approximate the time of metamorphism. If there were two events, this age would provide a minimum age for regional amphibolite-facies metamorphism. Widely ranging $\mathrm{K}$-Ar ages (Turner and others, 1979) and $\mathrm{Rb}-\mathrm{Sr}$ mineral ages (686 $\pm 116 \mathrm{Ma}$, Armstrong and others, 1986) overlap, within uncertainties, the crystallization age reported here and are consistent with metamorphism occurring at about the same time as igneous emplacement.

Age data presented here provide the most precise and unambiguous constraint on the Late Proterozoic age of magmatism and metamorphism in the Brooks Range. Granitic rocks in the metamorphic complex at Mount 
Table 3. Uranium-lead concentration and composition data from zircon from granitic rocks at Mount Angayukaqsraq

\begin{tabular}{|c|c|c|c|c|c|c|c|c|c|c|c|c|}
\hline \multirow{3}{*}{ Fraction 1} & \multirow{3}{*}{$\begin{array}{c}\text { Weight } \\
\text { (mg) }\end{array}$} & \multirow{2}{*}{\multicolumn{2}{|c|}{$\begin{array}{c}\text { Concentration } \\
(\mathrm{ppm})\end{array}$}} & \multicolumn{3}{|c|}{$\mathrm{Pb}$ composition ${ }^{2}$} & \multicolumn{3}{|c|}{ Ratios (percent error) ${ }^{3}$} & \multicolumn{3}{|c|}{ Ages $(\mathrm{Ma})^{4}$} \\
\hline & & & & $206 \mathrm{~Pb}$ & $206 \mathrm{~Pb}$ & $206 \mathrm{~Pb}$ & ${ }^{206} \mathrm{~Pb}$ & ${ }^{207} \mathrm{~Pb}$ & $207 \mathrm{~Pb}$ & $206 \mathrm{~Pb}$ & ${ }^{207 \mathrm{~Pb}}$ & ${ }^{207 \mathrm{~Pb}}$ \\
\hline & & $u$ & $\mathrm{~Pb}$ & $\overline{204 \mathrm{~Pb}}$ & $\overline{207 \mathrm{~Pb}}$ & $\overline{208 \mathrm{~Pb}}$ & $\overline{238 \mathrm{U}}$ & $\overline{{ }^{235} \mathrm{U}}$ & $\overline{{ }^{206} \mathrm{~Pb}}$ & $\overline{238} \mathrm{U}$ & $235 \mathrm{U}$ & $\overline{206 \mathrm{~Pb}}$ \\
\hline \multicolumn{13}{|c|}{ 78Md120 (locality 8A, fig. 2) granodiorite } \\
\hline Zircon $^{5}$ & 8.6 & 68.9 & 9.10 & 1987 & 13.99 & 4.669 & 0.1186 & 1.051 & 0.0642 & 723 & 729 & 750 \\
\hline Zircon ${ }^{3}$ & 3.8 & 143.3 & 19.1 & 2908 & 14.36 & 4.876 & .1207 & 1.076 & .0647 & 735 & 742 & 764 \\
\hline Zircon $^{5}$ & 7.0 & 253.2 & 31.9 & 20370 & 15.41 & 5.605 & .1169 & 1.035 & .0640 & 713 & 721 & 748 \\
\hline
\end{tabular}

85Dn19 (locality 8C, fig. 2) granodiorite [recollection of 78Md120]

\begin{tabular}{|c|c|c|c|c|c|c|c|}
\hline$(-150+200) N M D$ & 4.67 & 107.3 & 14. & 604 & & 405 & \\
\hline
\end{tabular}

$85 \mathrm{Dn} 24$ (locality 1C, fig. 2) alkali feldspar granite [recollection of 78Md119]

\begin{tabular}{|c|c|c|c|c|c|c|c|c|c|c|c|c|}
\hline$(-200+250)$ & .67 & 847.2 & 54.95 & 834.97 & 12.522 & 3.8972 & $.0551(.56)$ & $.4756(.59)$ & $.0625(.17)$ & 346 & 395 & 693 \\
\hline$(-250+325) \mathrm{NM}$ & 4.61 & 861.9 & 57.65 & 920.57 & 12.773 & 4.0874 & $.0576(.48)$ & $.4968(.49)$ & $.0626(.10)$ & 361 & 410 & 694 \\
\hline$(-325+400) \mathrm{NM}$ & 4.70 & 726.3 & 49.80 & 1746.1 & 13.878 & 4.4432 & $.0608(.50)$ & $.5345(.50)$ & $.0638(.07)$ & 380 & 435 & 735 \\
\hline$(-400)$ & .72 & 1321 & 110.4 & 407.06 & 10.355 & 3.1936 & $.0658(.78)$ & $.5529(2.3)$ & $.0610(2.1)$ & 411 & 447 & 639 \\
\hline
\end{tabular}

${ }^{1}$ Abbreviations: NM (non-magnetic), D (diamagnetic).

${ }^{2}$ Corrected for 1 nanogram laboratory blank and mass fractionation of $0.14 \pm .05$ percent atomic mass unit.

${ }^{3} 2 \sigma$ errors where shown in parentheses. Otherwise, uncertainties assumed to be 0.75 percent.

${ }^{4}$ Common lead corrected for using appropriate values from Stacey and Kramer (1975). Uranium decay constants from Steiger and Jäger (1977).

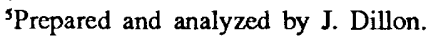

Angayukaqsraq have been correlated with the Ernie Lake and Sixtymile River orthogneiss bodies in the central Brooks Range (fig. 1) on the basis of broadly similar Proterozoic ${ }^{207} \mathrm{~Pb} /{ }^{206} \mathrm{~Pb}$ ages (Dillon and others, 1980; 1987). However, available isotopic age data for the Ernie Lake and Sixtymile River bodies show a high degree of discordance and scatter, such that crystallization ages can be only roughly estimated to be Middle and Late Proterozoic. The analyzed zircon fractions from these rocks show evidence of inheritance of an older crustal component $\left({ }^{207} \mathrm{~Pb} /{ }^{206} \mathrm{~Pb}\right.$ ages of 800 to $1,000 \mathrm{Ma}$, Dillon and others, 1980). The lack of a significant inherited component in the zircon fractions from granitic rocks at Mount Angayukaqsraq may reflect differences in source material, composition of the local country rocks, or crustal level of emplacement or generation of the magmas. Lithologic and chemical comparisons await further study of the other Proterozoic rocks in the Brooks Range.

\section{CONCLUSIONS}

The intrusive rocks at Mount Angayukaqsraq consist dominantly of gabbro, which is locally intruded by small bodies of granite and associated with bodies of granite and granodiorite. A U/Pb age of $750 \pm 6 \mathrm{Ma}$ for the granodiorite and granite are thus interpreted to represent a minimum age for the gabbro. These rocks provide the best evidence to date for the timing of Proterozoic magmatism and amphibolite-facies metamorphism of the country rocks in the structural core of the Brooks Range. Metamorphic minerals and cataclastic textures in the intrusive rocks are attributed to blueschist/greenschist-facies metamorphism that affected the metamorphic complex at Mount Angayukaqsraq during Cretaceous Brookian deformation. Further studies and more precise geochronology will be necessary to determine whether the Sixtymile River and Ernie Lake orthogneiss bodies record different Proterozoic events and different tectonic settings of deformation.

\section{REFERENCES CITED}

Aleinikoff, J.N., Dusel-Bacon, Cynthia, and Foster, H.L., 1986, Geochronology of augen gneiss and related rocks, Yukon-Tanana terrane, east-central Alaska: Geological Society of America Bulletin, v. 97, p. 626-637.

Anders, Edward, and Ebihara, Mitsuru, 1982, Solar-system abundances of the elements: Geochimica et Cosmochimica Acta, v. 46, p. 2362-2380.

Armstrong, R.L., Harakal, J.E., Forbes, R.B., Evans, B.W., and Thurston, S.P., 1986, Rb-Sr and K-Ar study of metamorphic rocks of the Seward Peninsula and Southern Brooks Range, Alaska: Geological Society of America Memoir 164 , p. $185-203$.

Cullers, R.L., and Graf, J.L., 1984, Rare-earth-elements in igneous rocks of the continental crust: Intermediate and silicic rocks: Ore petrogenesis, in Henderson, Paul., ed., 
Rare-earth-element geochemistry: Developments in geochemistry: New York, Elsevier, v. 2, p. 277-316.

Dillon, J.T., Pessel, G.H., Chen, J.H., and Veach, N. C., 1980, Middle Paleozoic magmatism and orogenesis in the Brooks Range, Alaska: Geology, v. 8, p. 338-343.

Dillon, J.T., Tilton, G.R., Decker, J., and Kelly, M.J., 1987, Resource implications of magmatic and metamorphic ages for Devonian igneous rocks in the Brooks Range, in Tailleur, I. L., and Weimar, Paul, eds., Alaskan North Slope geology: Bakersfield, Calif., Pacific Section Society of Economic Paleontologists and Mineralogists and Alaska Geological Society, Book 50, p. 713-723.

Jones, D.L., Silberling, N.J., Coney, P.J., and Plafker, George, 1984, Lithotectonic terrane map of Alaska, in Silberling, N.J., and Jones, D.L., eds., Lithotectonic terrane map of the North American Cordillera: U.S. Geological Survey Open-File Report 84-523, Part A, scale 1:2,500,000.

Mayfield, C.F., Silberman, M.L., and Tailleur, I.L., 1982, Precambrian metamorphic rocks from the Hub Mountain terrane, Baird Mountains quadrangle, Alaska, in Coonrad, W.L., ed., The U.S. Geological Survey in
Alaska: Accomplishments during 1980: U.S. Geological Survey Circular 844, p. 18-24.

Mayfield, C.F., Tailleur, I.L., and Ellersieck, Inyo, 1983, Stratigraphy, structure, and palinspastic synthesis of the western Brooks Range, northwestern Alaska: U.S. Geological Survey Open-File Report 83-779, 58 p.

Oldow, J.S., Seidensticker, C.M., Phelps, J.C., Julian, F.E., Gottschalk, R.R., Boler, K.W., Handschy, J.W., and Avé Lallement, H.G., 1987, Balanced cross-section through the central Brooks Range and North Slope, Arctic Alaska: Tulsa, American Association of Petroleum Geologists, 19 p., 8 plates.

Pearce, J.A., Harris, N.B.W., and Tindle, A.G., 1984, Trace element discrimination diagrams for the tectonic interpretation of granitic rocks: Journal Petrology, v. 25, p. 956-983.

Stacey, J.S., and Kramer, J.D., 1975, Approximation of terrestrial lead isotope evolution by a two-stage model: Earth and Planetary Science Letters, v. 26, p. 207-221.

Steiger, R.H., and Jäger, E., 1977, Subcommission on geochronology: Convention on the use of decay constants in geo-

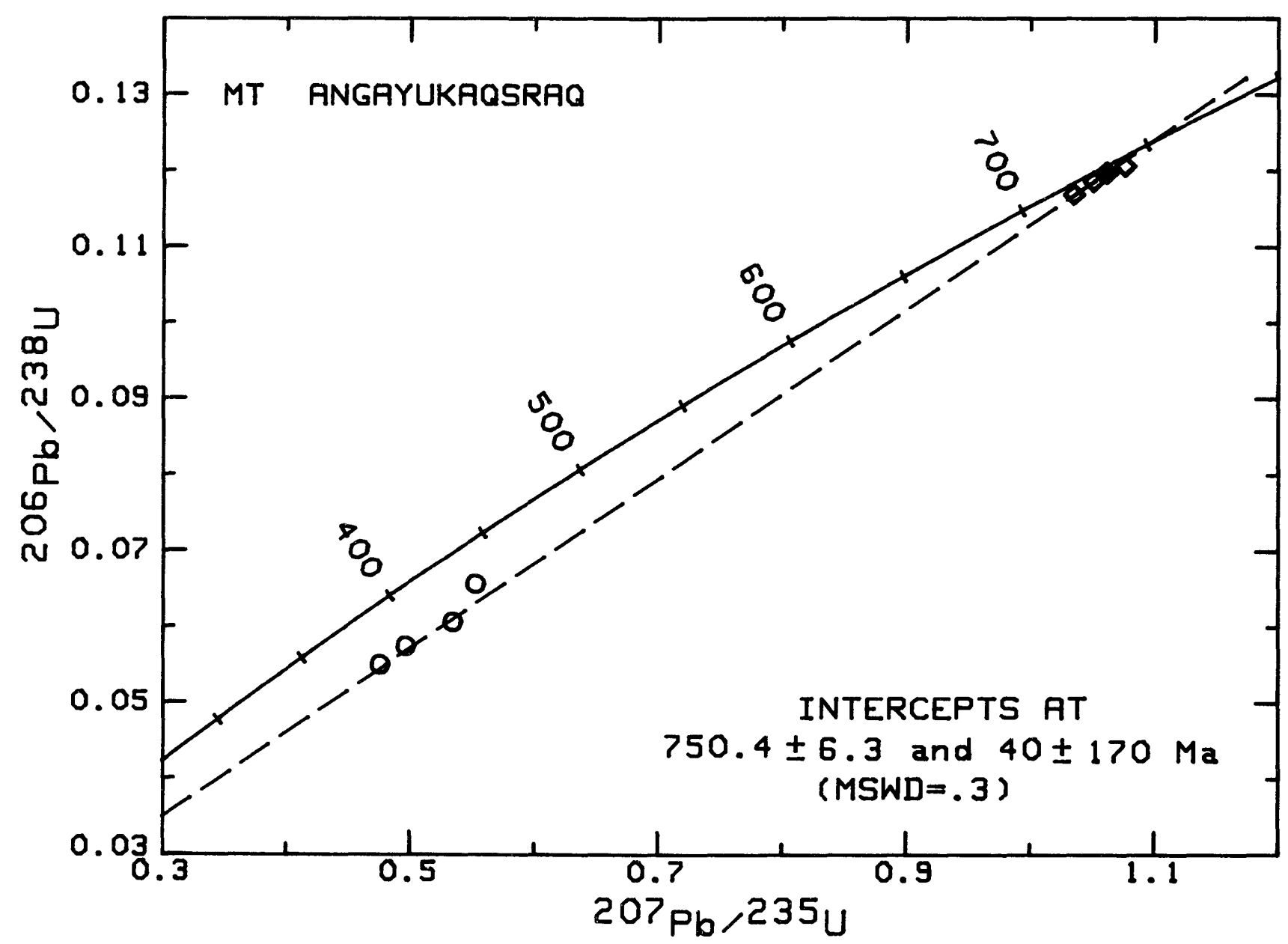

Figure 6. Concordia plot of lead-uranium zircon analyses from intrusive rocks at Mount Angayukaqsraq. Circles are sample 85Dn24 (granite) (locality 1C, fig. 2), open diamonds are 78Md120 (granodiorite) (locality 8A, fig. 2), and filled diamond is 85Dn19 (granodiorite) (locality 8C, fig. 2). Regression is through three of four granodiorite data points (see text for explanation). Sample data listed in table 3. 
and cosmochronology: Earth and Planetary Science Letters, v. 36, p. 359-362.

Streckeisen, A., 1976, To each plutonic rock its proper name: Earth Science Reviews, v. 12, p. 1-33.

Till, A.B., Schmidt, J.S., and Nelson, S.W., 1988, Thrust involvement of metamorphic rocks, southwestern Brooks Range, Alaska: Geology, v. 16, p. 930-933.

Turner, D. L., Forbes, R.B., and Dillon, J.T., 1979, K-Ar geochronology of the southwestern Brooks Range, Alas- ka: Canadian Journal of Earth Sciences, v. 16, p. 1789-1804.

\section{Reviewers:}

Alison Till
Jack Bradshaw 


\title{
Proterozoic Rocks of the Western Brooks Range
}

\author{
By Alison B. Till
}

\begin{abstract}
Proterozoic rocks have been recognized at two areas in the western Brooks Range, at Mount Angayukaqsraq in the northeast Baird Mountains quadrangle and on the upper Ipnelivik River in the northeast Ambler River quadrangle. In both areas they are associated with lower Paleozoic carbonate and volcanic rocks and consist of a distinctive lithologic assemblage of amphibolite, pelite, metaquartzite, and calcschist, intruded by two types of igneous rocks. The earliest metamorphic event recorded in the assemblage was amphibolite facies in grade and probably occurred between 600 and $750 \mathrm{Ma}$. At Mount Angayukaqsraq amphibolite- facies mineral assemblages locally have been overprinted by blueschist-facies assemblages; the blueschist-facies event is thought to have occurred during the Phanerozoic.
\end{abstract}

\section{INTRODUCTION}

Proterozoic rocks were first recognized in the western Brooks Range fold and thrust belt during reconnaissance mapping by Mayfield and others (1982; fig. 1, area $\mathrm{A}$ ). Metasedimentary and metaigneous rocks in the northeast Baird Mountains quadrangle yielded Late Proterozoic K-Ar ages (Turner and others, 1979; Mayfield and others, 1982); these ages were confirmed by Armstrong and others (1986) using Rb-Sr isotopes. Although a Late Proterozoic metamorphic event was proposed by these workers; confusion over the grade of that event persisted, because mineral assemblages typical of both amphibolite and blueschist facies are present. Gilbert and others (1977) and Turner and others (1979) suggested that blueschist-facies metamorphism occurred during the Proterozoic; this question remained unresolved despite further isotopic work by Armstrong and others (1986).

Detailed mapping and petrographic work (1985-1988) in the Baird Mountains and Ambler River 1:250,000-scale quadrangles were undertaken to better characterize the Proterozoic rocks and to look for evidence for the relative ages of amphibolite- and blueschist-facies mineral assemblages. During the course of mapping, rocks identical to those at the original Proterozoic locality were recognized in the northeast
Ambler River quadrangle, in the Ipnelivik River valley (fig. 1, area I).

This short description of the Proterozoic rocks is intended as an aid to their field recognition in the western and central Brooks Range. In addition, a preliminary description of thin-section textures indicating relative ages of amphibolite- and blueschist-facies events is included.

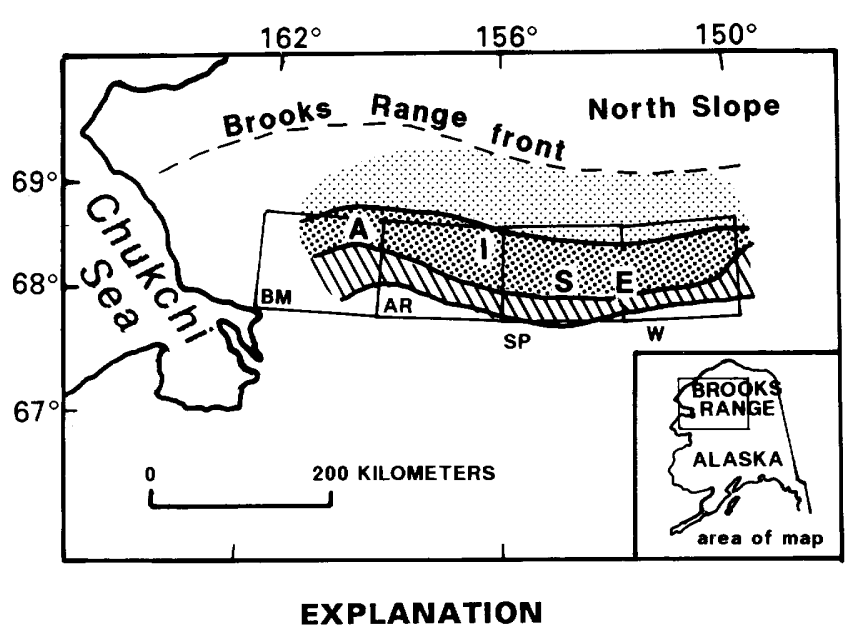

Schist belt
Central belt of Till and others (1988)
Endicott allochthon

Areas having Proterozoic or Proterozoicl?) rocks

$\begin{array}{ll}\text { A } & \begin{array}{l}\text { Mount Angayukaqsraq } \\ \text { I }\end{array} \\ \text { S } & \begin{array}{l}\text { Paleozolivic River } \\ (1980)\end{array} \\ \text { E } & \begin{array}{l}\text { Ernie Lake pluton and surrounding rocks } \\ 1: 250,000 \text {-scale quadrangles }\end{array} \\ & \text { Baird Mountains } \\ \text { BM } & \text { Ambler River } \\ \text { AR } & \begin{array}{l}\text { Survey Pass } \\ \text { SP }\end{array} \\ \text { W } & \text { Wiseman }\end{array}$

Figure 1. Sketch of central and western Brooks Range showing selected geographic and geologic features. 


\section{THE PROTEROZOIC ASSEMBLAGE}

\section{Lithologic description}

Proterozoic metamorphic rocks at Mount Angayukaqsraq (fig. 1, area A), in the northeast Baird Mountains quadrangle and in the upper Ipnelivik River valley in the northeast Ambler River quadrangle (area I), consist of a distinctive lithologic assemblage of amphibolite, pelite, metaquartzite, and calc-schist. Volumetrically minor granitic and gabbroic rocks also occur. Lithologies are complexly interlayered, and no internal organization can be recognized.

Amphibolite, metaquartzite, calc-schist, and pelite commonly form massive or layered outcrops (fig. 2). Lithologies are interlayered on a scale of centimeters to meters with pelite layers rarely thicker than a meter and the other lithologies in layers up to tens of meters thick. Intrafolial isoclinal folds are commonly preserved where lithologic layering occurs on a scale of centimeters.
Amphibolite forms dark-gray- to black-weathering massive outcrops dotted with pink garnets or rare creamcolored plagioclase porphyroblasts. Locally hornblende grains define a northwest-trending lineation. Garnets are up to $1.5 \mathrm{~cm}$ in diameter and occur in a lepidoblastic matrix of medium-green to olive-green hornblende, plagioclase, sphene, quartz, and accessory minerals (fig. 3 ). Garnets usually make up less than 10 percent of the rock, and hornblende generally more than 65 percent.

Metaquartzite forms tan-, green-, and grayweathering massive layers with a sugary texture, interlayered on a millimeter to centimeter scale with tan-, yellow-, brown-, and gray-weathering massive calc-schist. This interlayering produces a color-lamination in outcrop. The metaquartzite is equigranular, granoblastic, and contains less than 15 percent white mica, biotite, garnet, and calcite. The calc-schist is composed of quartz, epidote, plagioclase, hornblende, and garnet in various proportions; it is also equigranular and has a granoblastic texture in thin section.

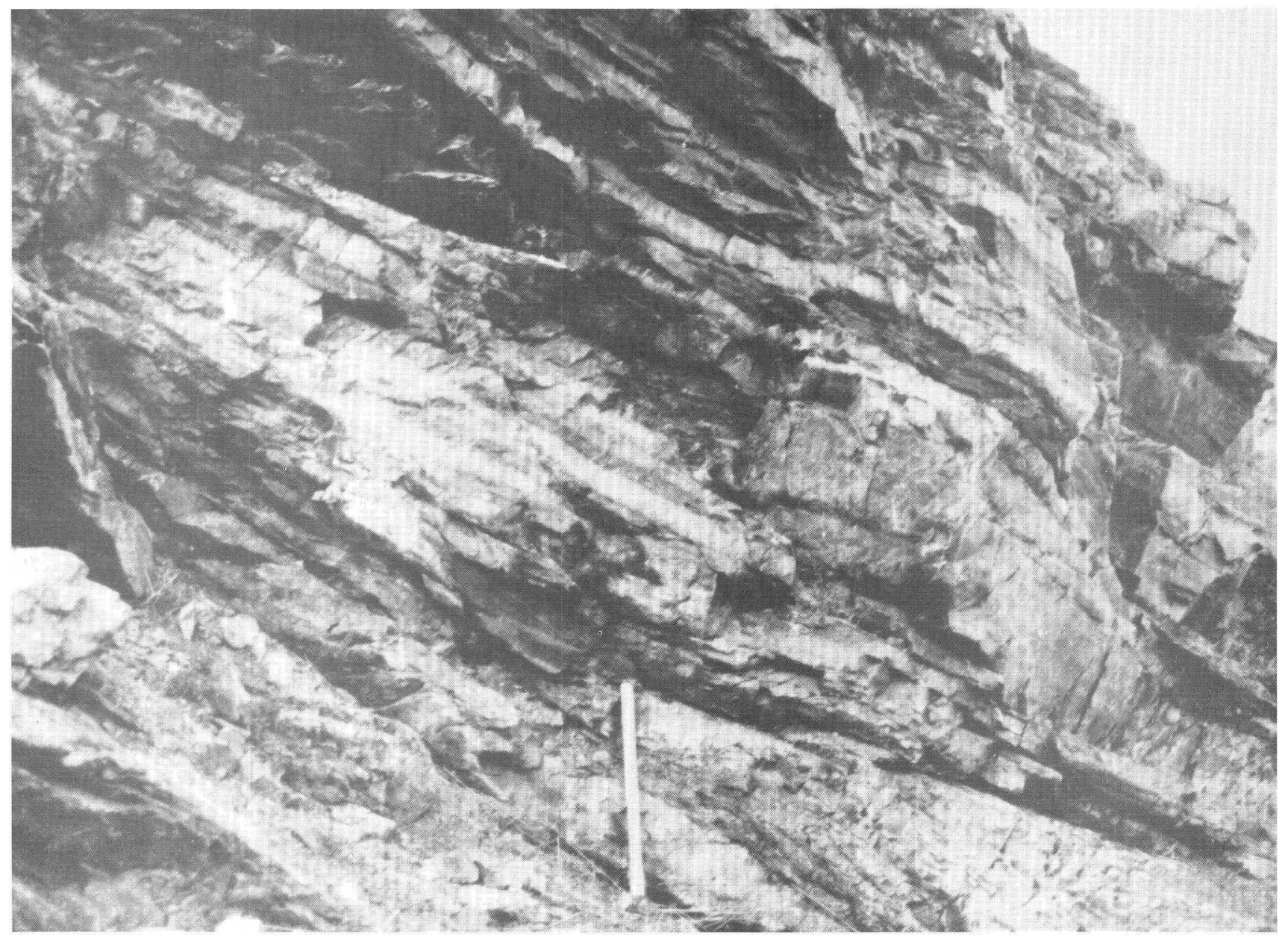

Figure 2. Outcrop of interlayered metaquartzite, calc-schist, and garnet amphibolite in drainage immediately south of Mount Angayukaqsraq. Most of outcrop is metaquartzite and calc-schist; thick $(25-30 \mathrm{~cm})$ massive lens in right central part of photograph is garnet amphibolite. Hammer handle is $30 \mathrm{~cm}$ long. 
Pelite forms light-green to whitish-weathering layers easily recognizable due to the abundance of white mica. Pelite layers are several tens of centimeters thick or less and are interlayered with metaquartzite; the boundaries between quartz-rich and mica-rich layers may be sharp or gradational. Muscovite forms 20 to 60 percent of the rock. Pink garnets up to $6 \mathrm{~mm}$ in diameter are common (up to 20 percent) in the pelite and may appear to be pale green where they are rimmed or replaced by chlorite. Biotite occurs in some pelites, but is generally less than 5 percent of the rock.

Light-gray- to tan-weathering granite occurs in bodies tens of centimeters to meters across and is massive to weakly foliated (Karl and others, this volume). The granite contains K-feldspar, plagioclase, quartz, white mica, zircon, sphene, and locally biotite, white mica, garnet, epidote, and allanite. The rock is equigranular at some localities, seriate in others. Grain boundaries are complex. Plagioclase and K-feldspar are not zoned; no crystal growth faces are present on feldspar grains. It is difficult to determine whether both thin- section textures and the epidote, garnet, and white mica in the granitic rock are igneous or metamorphic. In most cases the boundaries of the granitic bodies cannot be observed or are faults, so that this problem cannot be resolved in the field.

Blotchy cream- and brownish-green-weathering metagabbro occurs in plugs and stocks up to 100 meters across. The largest body known is on the ridge that contains Mount Angayukaqsraq. The most common gabbro is massive, and igneous textures are well preserved on both outcrop and thin-section scales. Relicts of igneous clinopyroxene, hornblende, and plagioclase are found in some thin sections, although they are more commonly replaced by pale-green amphibole, epidote, and albite. Rutile, sphene, and quartz are accessory minerals. In some samples, pseudomorphism has produced a mat of fine actinolite needles after mafic minerals and a mat of tabular zoisite or epidote after plagioclase.

The persistence of igneous minerals and textures in the metagabbro is strong evidence that it did not undergo

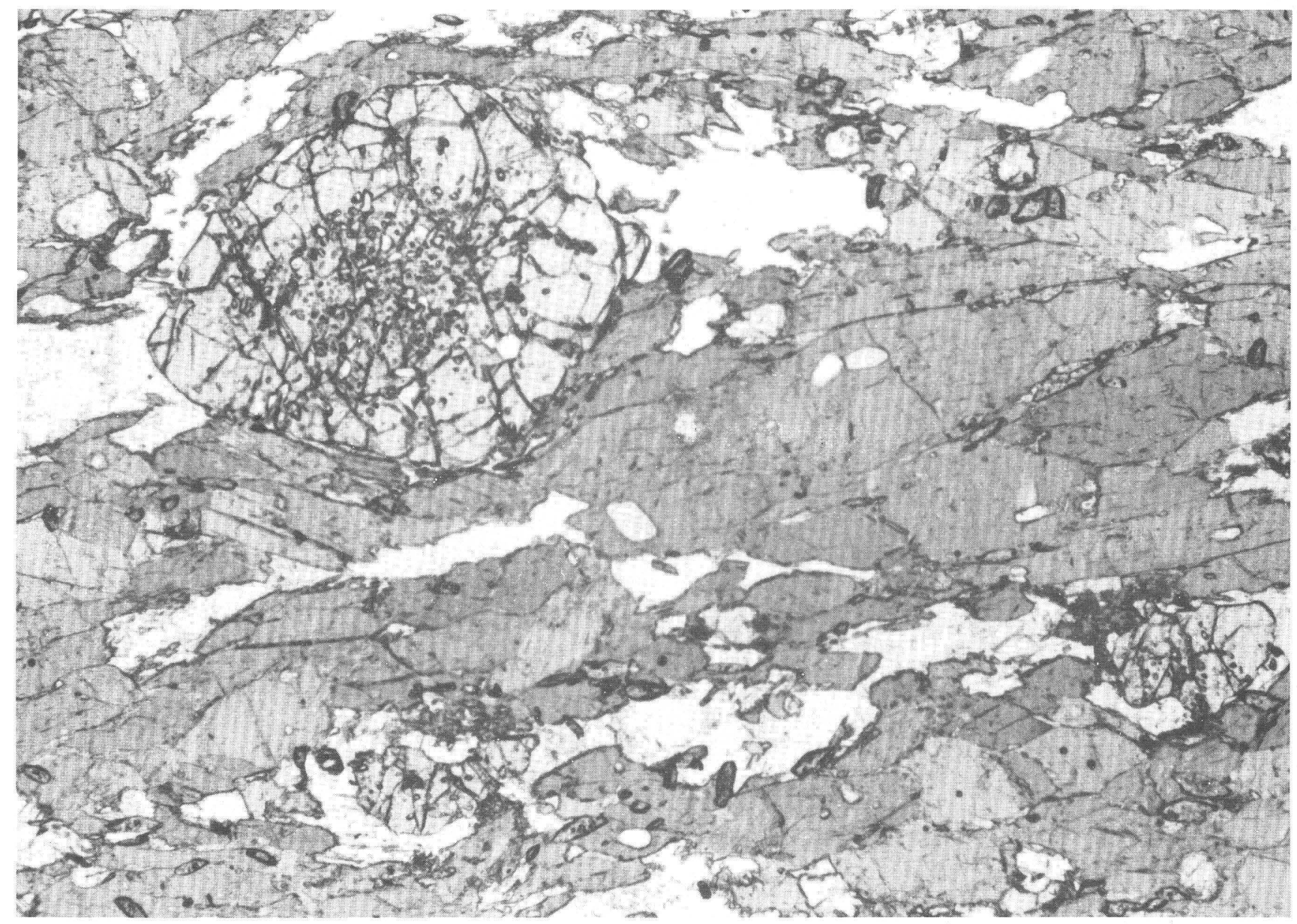

Figure 3. Photomicrograph of garnet amphibolite collected from ridge south of Mount Angayukaqsraq. Large porphyroblast in upper left and small, high-relief grains in lower part of photograph are garnet. Hornblende, plagioclase, quartz, and sphene comprise matrix. Field of view is $2 \mathrm{~mm}$. 
amphibolite-facies metamorphism; therefore, the metagabbro is younger than the other lithologies. The greenschist-facies overprint on the gabbro is thought to be the result of a Mesozoic metamorphic event.

The earliest metamorphic event recorded in the Proterozoic metasedimentary and metaigneous rocks was of amphibolite grade. The hornblende-plagioclasegarnet assemblage in the amphibolite is diagnostic of that grade; the quartz-muscovite-biotite-garnet assemblage in the pelite is consistent with it. The hornblende and muscovite which yielded Late Proterozoic ages crystallized during that amphibolite-facies event.

\section{Age}

Isotopic ages were determined for rocks and minerals from the Mount Angayukaqsraq area collected during reconnaissance mapping (Mayfield and others, 1982). K-Ar ages on hornblendes from amphibolites are $595 \pm 30 \mathrm{Ma}$ and $729 \pm 22 \mathrm{Ma}$ (Mayfield and others, 1982; Turner and others, 1979, respectively). K-Ar ages for two muscovite samples are $646 \pm 19 \mathrm{Ma}$ and $594 \pm 18$ Ma (Turner and others, 1979; Mayfield and others, 1982). Rb-Sr determinations on the same samples used by Turner and others yielded a whole-rock model age from a mica schist of $645 \pm 19 \mathrm{Ma}$ and a muscovite age of $770 \pm 23 \mathrm{Ma}$ (Armstrong and others, 1986). Model ages were determined using an intercept value taken from analysis of a mafic schist in the same outcrop. An isochron constructed from whole-rock values of mafic schist and mica schist indicated an age of $686 \pm 116 \mathrm{Ma}$ (Armstrong and others, 1986). These ages show considerable scatter, but suggest that amphibolite-facies metamorphism occurred prior to $600 \mathrm{Ma}$ and possibly before $650 \mathrm{Ma}$.

Granitic rocks collected near Mount Angayukaqsraq yielded a U-Pb zircon age of about $750 \mathrm{Ma}$ (Karl and others, this volume). This has been interpreted as an igneous crystallization age.

Hornblende from a metadiorite (possibly similar to the metagabbro described above) yielded a K-Ar age of $548 \pm 16 \mathrm{Ma}$ (Mayfield and others, 1982). As relict igneous hornblende is present in some metagabbro samples, this may reflect an intrusive rather than a metamorphic age.

\section{STRUCTURAL SETTING}

\section{Mount Angayukaqsraq Area}

Near Mount Angayukaqsraq, the Proterozoic metamorphic assemblage underlies an area of almost 60 square kilometers. These amphibolite-facies rocks are a large lens or series of lenses that were fault-imbricated with lower Paleozoic carbonate rocks and metavolcanic

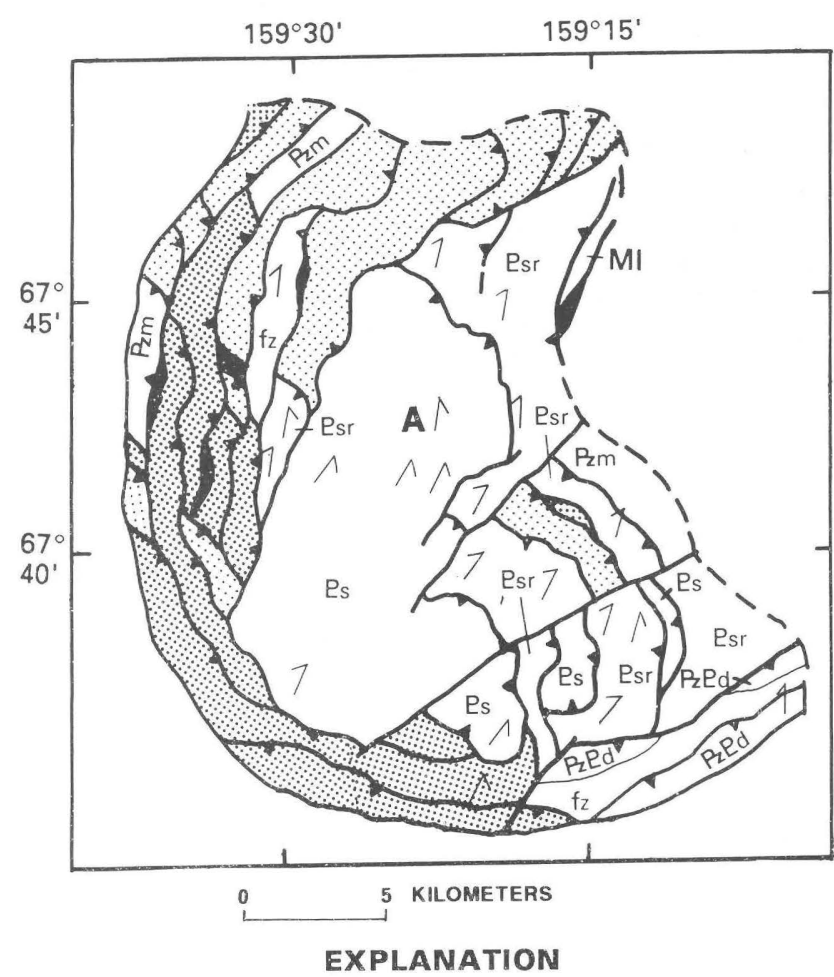

Mississippian limestone
$\begin{gathered}\text { Paleozoic quartz-rich metaclastic rocks- } \\ \text { Includes conglomerate }\end{gathered}$
$\begin{aligned} & \text { Silurian and Ordovician dolostone and } \\ & \text { marble } \\ & \text { Ordovician and Cambrian marble and } \\ & \text { limestone }\end{aligned}$
Paleozoic coarse-grained marble
Pst
$\begin{aligned} & \text { Paleozoic(?) and Proterozoic(?) dolostone } \\ & \text { and marble }\end{aligned}$
Proterozoic amphibolite-facies schist-
Partially recrystallized to blueschist-
facies minerals

Figure 4. Simplified geologic map of area around Mount Angayukaqsraq. See figure 1 for location of area. Modified from Till and others (1988). 
rocks (fig. 4) during Mesozoic development of the Brooks Range fold and thrust belt.

There is no evidence of amphibolite-facies metamorphism in the carbonate or metavolcanic rocks.

\section{Ipnelivik Area}

The Proterozoic lithologic assemblage is exposed over an area of $1.5 \mathrm{~km}^{2}$ in the upper Ipnelivik River drainage in the northeast Ambler River quadrangle (fig. $5)$.

These exposures, $17 \mathrm{~km}$ south of the confluence of the Ipnelivik with the Noatak River and $12 \mathrm{~km}$ north of Shishakshinovik Pass, were originally mapped as mafic intrusive rocks by Mayfield and Tailleur (1978). The structural setting of these Proterozoic rocks is unclear, but the Paleozoic carbonate rocks which overlie them are clearly thrust-imbricated. The carbonate rocks have been mapped as the Silurian and Devonian Skajit Limestone (Mayfield and Tailleur, 1978), but conodont collections within $3 \mathrm{~km}$ of the Proterozoic rocks yield Ordovician and Silurian ages (J. Dumoulin, unpublished data). The contacts between the Proterozoic rocks and the carbonate rocks and the base of the Proterozoic rocks are not exposed.

\section{OTHER PROTEROZOIC(?) ROCKS IN THE CENTRAL AND WESTERN BROOKS RANGE}

Banded schist and granitic gneiss of Proterozoic(?) age mapped in the western Wiseman quadrangle (fig. 1, area $\mathrm{E}$; units $\mathrm{Pb}$ and $\mathrm{Pg}$ of Dillon and others, 1986) are the most likely correlatives of the Mount Angayukaqsraq and Ipnelivik rocks in the central Brooks Range. The banded schist includes quartz-mica schist, metaquartzite, calc-schist, and metabasite, as well as marble and graphitic phyllite. As mapped, the banded sequence surrounds the Proterozoic(?) Ernie Lake pluton and related metagranitic rocks (Dillon and others, 1980). Similar units occur in the Survey Pass quadrangle as well.

A less likely but possibly correlative unit is the Paleozoic schist unit mapped in the south-central Survey Pass quadrangle by Nelson and Grybeck (1980), which contains pelite, quartzite, marble, greenstone, and orthogneiss (fig. 1, area S).

Figure 5. Simplified geologic map of Ipnelivik area (in northeastern Ambler River quadrangle). See figure 1 for location of area. Modified from Mayfield and Tailleur (1978) and A.B. Till, S.W. Nelson, J.M. Schmidt, and J.A. Dumoulin (unpub. mapping, 1986-1987).

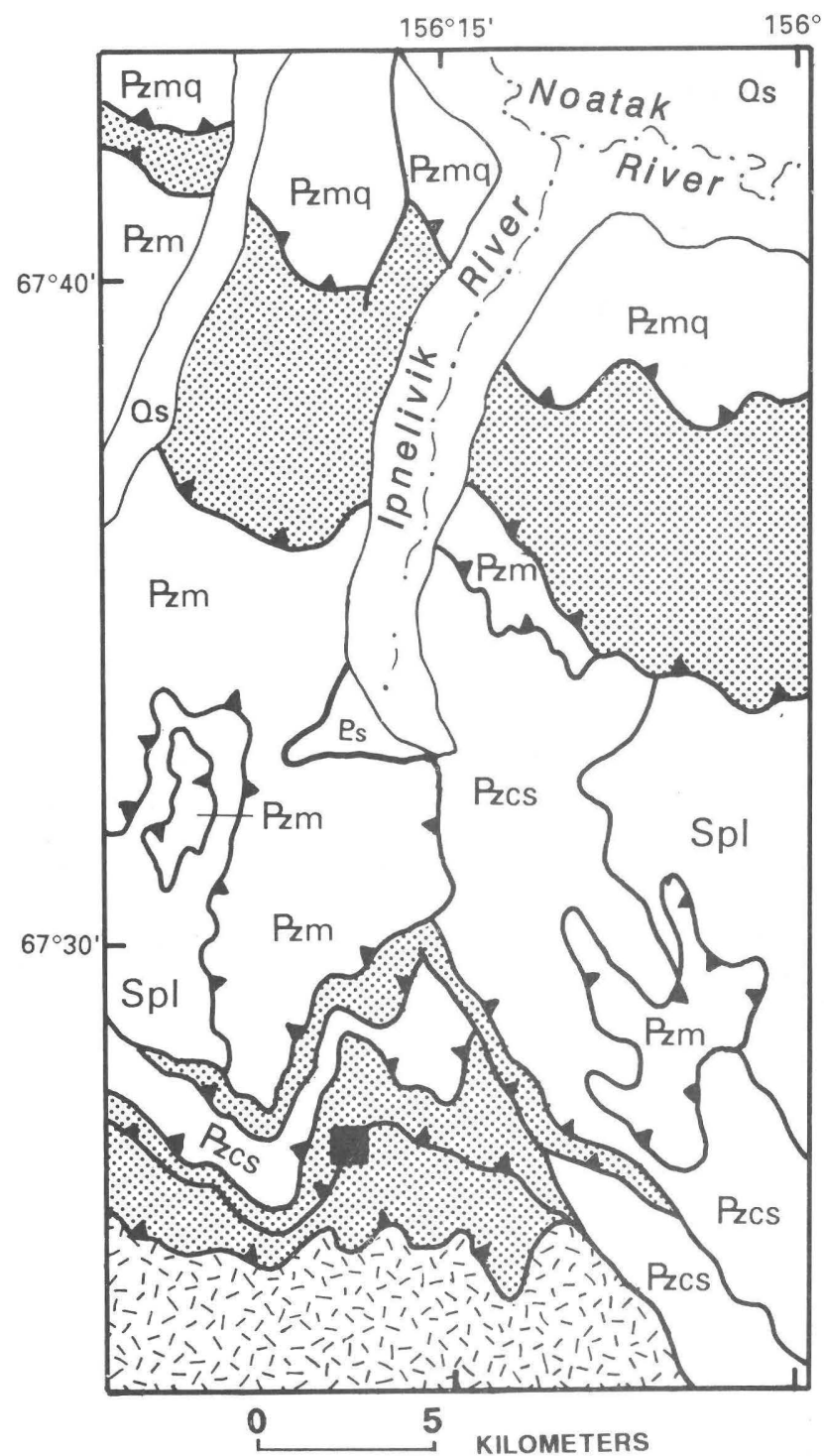

EXPLANATION

Qs Quaternary surficial rocks-Includes colluvium and alluvium

\begin{tabular}{|c|c|}
\hline - & Mississippian limestone and clastic rocks \\
\hline E:-1 & Devonian Shishakshinovik pluton \\
\hline Spl & Silurian(?) black phyllite and limestone \\
\hline Pzcs & Paleozoic calcareous and mafic schist \\
\hline Prmq & Paleozoic marble and quartzite \\
\hline Pzm & $\begin{array}{l}\text { Paleozoic marble and limestone-Includes } \\
\text { Skajit Limestone }\end{array}$ \\
\hline Ps & Proterozoic amphibolite-facies schist \\
\hline & Contact \\
\hline & Fault \\
\hline & Thrust fault-Sawteeth on upper plate \\
\hline & Shishakshinovik Pass \\
\hline
\end{tabular}




\section{RELATIVE AGE OF AMPHIBOLITE- AND BLUESCHIST-FACIES METAMORPHIC EVENTS}

Thin sections from the Mount Angayukaqsraq area show that several fault-bounded blocks of Proterozoic lithologies have undergone recrystallization. Hornblende in the amphibolite is rimmed and locally replaced by blue or blue-green amphibole; garnet in the amphibolite and pelite is replaced by chlorite \pm epidote. The petrographic evidence is therefore consistent with the growth of blueschist-facies minerals after amphibolite-facies minerals. Since the hornblende has yielded Proterozoic isotopic ages, the blueschist-facies event is inferred to be Phanerozoic in age.

\section{DISCUSSION}

The known and possible occurrences of Proterozoic rocks in the central and western Brooks Range are on structural trend with one another and are thought to occupy roughly the same structural position in the Mesozoic Brooks Range fold and thrust belt (fig. 1). The structural unit in which the Proterozoic assemblage is present is the central belt of Till and others (1988). The central belt is composed of Proterozoic and lower and middle Paleozoic rocks thrust-imbricated and locally metamorphosed during the Brooks Range orogeny. This belt is located between the metamorphic rocks of the schist belt, to the south, and clastic rocks of the Endicott allochthon, to the north (fig. 1; Mayfield and others, 1983). Proterozoic rocks may be discovered elsewhere in the central belt.

\section{CONCLUSIONS}

Proterozoic rocks in the western Brooks Range consist of a distinctive lithologic assemblage found near Mount Angayukaqsraq and on the upper Ipnelivik River. The assemblage includes amphibolite, pelite, metaquartzite, and calc-schist intruded by granitic and gabbroic rocks. The earliest metamorphic event recorded in the rocks was amphibolite facies in grade. Late Proterozoic isotopic ages obtained from hornblende and muscovite collected from exposures near Mount Angayukaqsraq are interpreted to represent the age of amphibolite-facies metamorphism, partially reset by subsequent recrystallization events.
Petrographic analysis of rocks at the Mount Angayukaqsraq locality shows that blueschist-facies assemblages have partially overprinted the Late Proterozoic amphibolite-facies assemblages in some fault-bounded blocks. The blueschist-facies metamorphism, therefore, was probably Phanerozoic in age.

\section{REFERENCES CITED}

Armstrong, R.L., Harakal, J.E., Forbes, R.B., Evans, B.W., and Thurston, S.P., 1986, Rb-Sr and K-Ar study of metamorphic rocks of the Seward Peninsula and southwestern Brooks Range, Alaska: Geological Society of America Memoir 164, p. 185-203.

Dillon, J. T., Brosgé, W.P., and Dutro, J.T., Jr., 1986, Generalized geologic map of the Wiseman quadrangle, Alaska: U. S. Geological Survey Open-File Report 86-219, 1 sheet, scale 1:250,000.

Dillon, J.T., Pessel, G.H., Chen, J.A., and Veach, N.C., 1980, Middle Paleozoic magmatism and orogenesis in the Brooks Range, Alaska: Geology, v. 8, p. 338-343.

Gilbert, W.G., Wiltse, M.A., Carden, J.R., Forbes, R.B., and Hackett, S.W., 1977, Geology of Ruby Ridge, southwestern Brooks Range, Alaska: Alaska Division of Geological and Geophysical Surveys Geologic Report 58, 16 p.

Mayfield, C.F., Silberman, M.L., and Tailleur, I.L., 1982, Precambrian metamorphic rocks from the Hub Mountain terrane, Baird Mountains quadrangle, Alaska, in Coonrad, W.L., ed., The U.S. Geological Survey in Alaska: Accomplishments during 1980: U.S. Geological Survey Circular 844, p. 18-24.

Mayfield, C.F., and Tailleur, I.L., 1978, Bedrock geology map of the Ambler River quadrangle, Alaska: U.S. Geological Survey Open-File Report 78-120-A, scale 1:250,000.

Mayfield, C.F., Tailleur, I.L., and Ellersieck, Inyo, 1983, Stratigraphy, structure, and palinspastic synthesis of the western Brooks Range, northwestern Alaska: U.S. Geological Survey Open-File Report 83-779, 4 sheets, 58 p.

Nelson, S.W., and Grybeck, Donald, 1980, Geologic map of the Survey Pass quadrangle, Alaska: U.S. Geological Survey Miscellaneous Field Studies Map MF 1176-A, scale 1:250,000.

Till, A.B., Schmidt, J.M., and Nelson, S.W., 1988, Thrustinvolvement of metamorphic rocks, southwestern Brooks Range, Alaska: Geology, v. 16, p. 930-933.

Turner, D.L., Forbes, R.B., and Dillon, J.T., 1979, K-Ar geochronology of the southwestern Brooks Range, Alaska: Canadian Journal of Earth Sciences, v. 16, p. 1789-1804.

\section{Reviewers:}

C. Dusel-Bacon

S. Karl 


\title{
Late Cenozoic Geologic Controls on Placer-Gold Distribution in the Nome Nearshore Area
}

\author{
By Darrell S. Kaufman and David M. Hopkins
}

\begin{abstract}
The spatial distribution of particulate gold in sediments blanketing the coastal plain at Nome is the product of a complex late Cenozoic geologic history. The diverse glacial, marine, fluvial, and deformational processes that shaped the sedimentary sequence on the emergent coastal plain have operated on the submerged continental shelf south of Seward Peninsula. Amino acid analysis of fossil molluscan shells from 51 boreholes drilled in 1967 by the U.S. Department of the Interior in the Nome nearshore area demonstrates that the upper $20 \mathrm{~m}$ of the offshore deposits have been pervasively reworked. Below $20 \mathrm{~m}$, sediments accumulated more continuously in a marine environment and contain minor amounts of particulate gold. The initiation of extensive reworking approximately coincides with the time of the late Pliocene Beringian marine transgression, after which glaciers advanced southward beyond the present-day coast and left deposits associated with the richest concentrations of particulate gold. Within the area extending approximately $5 \mathrm{~km}$ seaward of Nome, gold values in the top $20 \mathrm{~m}$ of sediment do not decrease seaward. The greatest concentrations are found within $4 \mathrm{~m}$ of the sea floor; lag-gravel deposits formed on till of the present sea floor are especially enriched. Although erosional surfaces analogous to the present sea floor may be buried within the sequence of Quaternary deposits, the extent of the gold-bearing glacial deposits that would support these surfaces is not fully delineated. Reconstructions must take into account the possibility that glaciers advanced onto the coastal plain during a period of high relative sea level. Coarse-grained potentially gold-bearing debris would have been carried farther beyond a glacier terminating in a marine environment than from terrestrialbased ice. A better understanding of the geologic processes that formed the sedimentary sequence onshore and offshore of Nome and consideration of theoretical constraints of placer-gold formation will lead to more reliable predictions of the distribution of particulate-gold concentrations.
\end{abstract}

\section{INTRODUCTION}

Since the turn of the century, the beaches of the Nome area (fig. 1) have attracted the attention of miners and scientists alike. The deposits were first mined for their fantastic quantities of gold (concentrations ranging to $300 \mathrm{~g} / \mathrm{m}^{3}$ were reported by Moffitt, 1913), and then studied by geologists who extracted from them a rich record of fluctuating Pleistocene sea level and glacial ice. Recently, the discovery and ongoing development of offshore placer-gold deposits beyond the southern coast of Seward Peninsula prompted a proposal by the U.S. Department of the Interior to lease more than 175,000 acres of sea floor for placer-gold mining (U.S. Minerals Management Service, 1988).

The offshore placer-gold resources of northern Norton Sound are distributed irregularly throughout a seaward-thickening wedge of unconsolidated marine and continental sediments of late Tertiary and Quaternary age. The geology and particulate-gold content of these deposits remains largely unknown and, at present, can only be inferred from a few investigations concentrated in the Nome nearshore area (U.S. Bureau of Mines, 1967; Nelson and Hopkins, 1972). Because the diverse glacial, marine, fluvial, and deformational processes that formed the sedimentary sequence of northern Norton Sound have operated on the emergent coastal plain of the Nome area, studies of the onshore deposits (MacNeil and others, 1943; Hopkins and others, 1960; Hopkins, 1967a, 1972, 1973; Kaufman and Hopkins, 1986) lend additional insight into the nature of the offshore sediments.

In the three decades since Hopkins (1959) put forth the original Quaternary stratigraphic framework for northwestern Alaska, a variety of new geologic evidence and analytical tools have become available to test and refine the original chronology. Studies of the Gubik Formation of the Arctic Coastal Plain, based largely on amino acid geochronology, have provided a more complete understanding of the number and timing of highsea-level events in Alaska (Brigham, 1985; Carter and others, 1986). Oxygen isotopes from deep-sea sediments reveal a complex series of major worldwide climatic fluctuations that modulated the growth and decay of continental ice sheets and consequent fluctuations in sea level. Eight isotopic stages, each corresponding to an interval of ice buildup and associated global sea-level depression, are recognized for the last 700,000 years alone (Shackleton and Opdyke, 1976). The continuity of the deep-sea record contrasts markedly with the rela- 
tively incomplete land-based record of interglacial shorelines and glacial-age moraines in the Nome area (fig. 2). Nonetheless, the striking environmental changes of the Quaternary have left their mark on the stratigraphy and particulate-gold distribution of northern Norton Sound.

The relevant findings of earlier investigations are integrated in this report with new and previously unpublished information, including stratigraphic, amino acid, and particulate-gold data from boreholes drilled in 1967 by the U.S. Department of the Interior in the Nome nearshore area. This report presents the Quaternary geological framework that, together with theoretical considerations, lend insight into the formation of placer-gold deposits in the Nome area and in regions of similar geologic context. A better understanding of the multi- tude of geologic processes that shaped the sedimentary sequence, both onshore and offshore, will lead to more reliable predictions of the distribution and magnitude of particulate-gold enrichments.

\section{REGIONAL GEOLOGIC SETTING}

Norton Sound is an extensional feature formed in continental basement rocks comprising a mixed assemblage of Precambrian to early Paleozoic pelitic schist, quartz-graphite schist, and marble. Basement rocks found in the Norton Sound COST wells in central Norton Sound (Turner, 1986) are similar to those exposed in the Seward Peninsula (Hummel, 1962; Sainsbury and others, 1972; Till and others, 1986). Rifting and associated

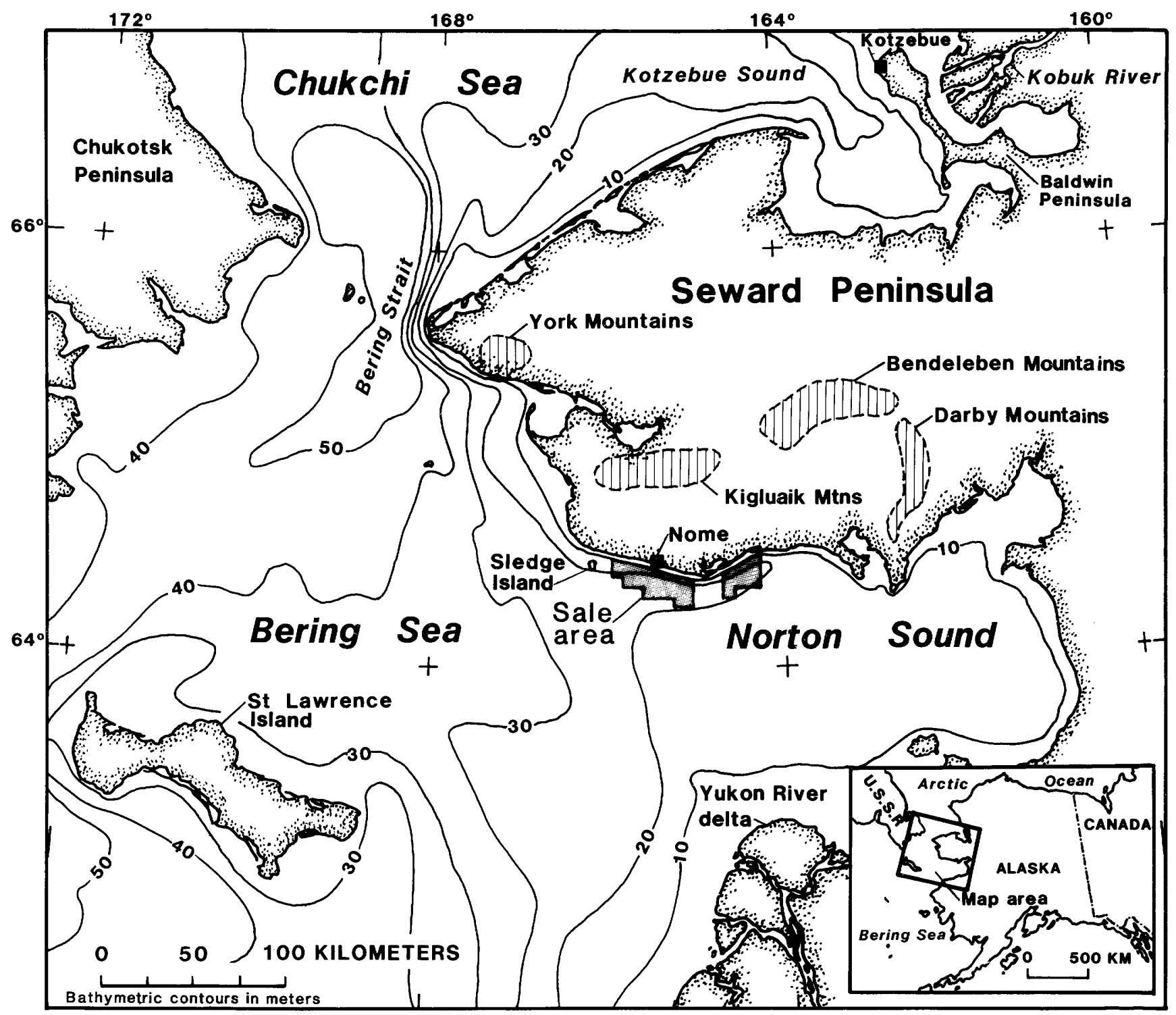

Figure 1. Location map of northern Bering Sea region showing generalized bathymetry (modified from Larsen and others, 1981; note that Hopkins and others, 1976, show that much of the bathymetric trough located south of Nome reaches depths in excess of $30 \mathrm{~m}$, deeper than the 20 meters or more shown here). 
subsidence began in the latest Cretaceous and early Tertiary and was followed by basin downwarping in the middle Tertiary that continues into the Holocene (Turner, 1986).

The present continental shelf of northern Bering Sea evidently lay above sea level until middle Tertiary time, when marine deposition began (Fisher and others, 1982). Throughout late Tertiary time, sea level in the deepest part of Norton Sound remained high enough to allow continuous marine deposition in an environment characterized by fluctuating salinity, cold water, and relatively high sedimentation rate (Turner, 1986). During this period, the highest part of the continental platform formed a land bridge connecting Alaska to eastern
Siberia, allowing unrestrained terrestrial migrations between North America and Asia (Hopkins, 1967b).

Near the end of the Pliocene Epoch, about 3.5 million years ago, relative sea level rose high enough to breach the Bering land bridge near the site of present-day Bering Strait (Herman and Hopkins, 1980). This submergence episode, the Beringian transgression of Hopkins (1967a), is recorded by the oldest marine sediments recognized along Alaskan coasts that adjoin the continental shelves of Bering and Chukchi Seas. At the type locality near Nome, the Beringian transgression is represented by gold-bearing and richly fossiliferous sand and clay resting on an undulating bedrock surface approximately $8 \mathrm{~m}$ below sea level (fig. 3).

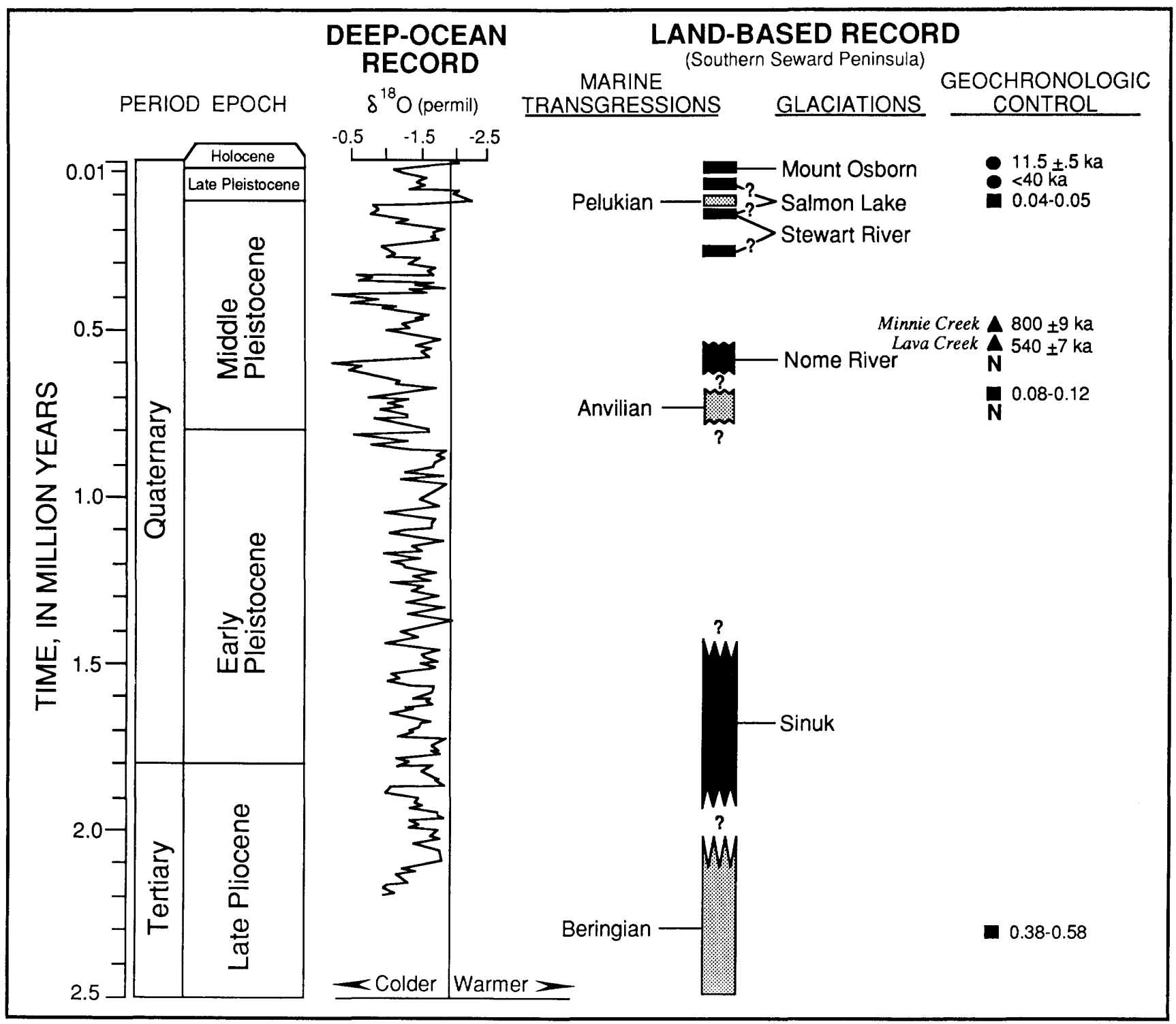

Figure 2. Comparison of deep-ocean record of fluctuating ice volume with land-based record of marine transgressive (stippled bar) and glacial (solid bar) intervals (queried where uncertain) recorded on southern Seward Peninsula ( ${ }^{18} \mathrm{O}$ record from Shackleton and Opdyke, 1976, Pacific core V28-239). Radiometric ages are in thousands of years B.P. (ka); circle, radiocarbon age; triangle, potassium-argon age. Amino acid ratios (squares) are alle/lle for total fraction in $M y a$. $\mathrm{N}$, normal magnetic polarity. Age of lava flow at Minnie Creek (Kaufman and Hopkins, 1986) is considered spurious; see text for discussion. 
Bouldery diamicton and coarse-grained gravel of the Sinuk glacial interval (Kaufman and Hopkins, 1986) is found stratigraphically above marine sediments of the Beringian transgression and below fossiliferous marine sediments of the younger Anvilian transgression. The higher relative sea level of Anvilian time deposited sorted sand and washed gravel at about $6 \mathrm{~m}$ above present sea level.
Renewed glaciation of the Nome coastal plain is recorded by erratic-bearing diamicton and bouldery gravel of the Nome River glaciation that overlies Anvilian marine sediments. Glaciers of the Nome River glaciation originated in the rolling hills inland of Nome and in the high Kigluaik Mountains more than $50 \mathrm{~km}$ to the north (fig. 1). The Nome River deposits are notched by and are therefore older than a high sea-level shoreline formed
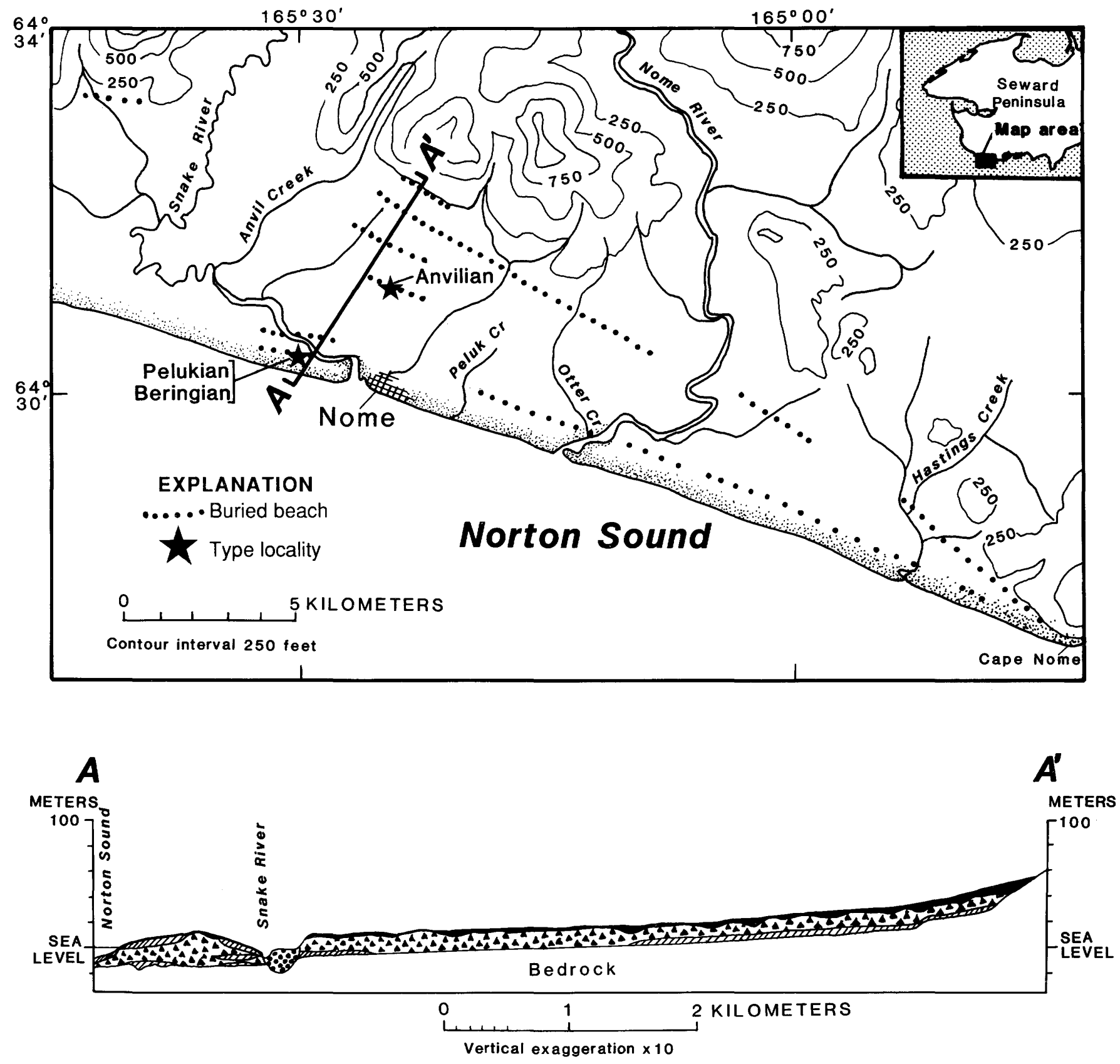

EXPLANATION

Peat, loess, and colluvium

Figure 3. Generalized geologic map and cross section of coastal plain at Nome (modified from Hopkins and others, 1960). Map shows locations of marine transgression type localities and buried beaches. 
during the last major interglaciation. A much greater age for the Nome River glaciation is suggested by potassiumargon ages on the Minnie Creek lava flow, located about $120 \mathrm{~km}$ north of Nome in central Seward Peninsula. At Minnie Creek, a moraine assigned to the Nome River glaciation was overrun by a normally magnetized basaltic lava flow that has yielded an age of $810 \pm 90 \mathrm{ka}$ on plagioclase (Kaufman and Hopkins, 1986). This determination is corroborated by a whole-rock analysis performed at the Alaskan Cooperative Geochronology Laboratory that yielded an age of $797 \pm 59 \mathrm{ka}$ (D. Turner, University of Alaska, written commun., 1987). However, Nome River till at the type locality at Nome appears to be normally magnetized (D.S. Kaufman, University of Colorado, unpub. data, 1988), and amino acid ratios in molluscan shells from the underlying beach sediments of the Anvilian marine transgression (this report) favor an age considerably younger than $800 \mathrm{ka}$. The Minnie Creek lava flow may contain excess argon and, until further analyses are completed, we consider its age spuriously old. We suggest that the age of the basaltic lava flow that erupted in the valley of Lava Creek, located in the southeastern Bendeleben Mountains, provides a more reasonable minimum limiting age on the Nome River glaciation (fig. 2). This normally magnetized lava flow, dated at $564 \pm 66 \mathrm{ka}$ (D. Turner, University of Alaska, written commun., 1987), invaded the glacial trough of Lava Creek sometime after the Nome River glaciation.

Following the Nome River glaciation, the northern shoreline of Bering Sea has fluctuated over presently submerged areas of the continental shelf many times, but apparently it rose above its present position only once. Approximately 125,000 years ago, during the Pelukian marine transgression (Hopkins, 1967a), well-sorted and rounded sand and gravel were deposited seaward from a rather continuous shoreline scarp carved at an altitude of 10-12 $\mathrm{m}$. These gold-bearing beach sediments have been extensively mined on the Nome coastal plain, where gold was apparently reworked and concentrated from underlying glacial sediments.

In marked contrast to the Nome River glaciation, subsequent glacier advances (Stewart River, Salmon Lake, and Mount Osborn) were restricted to the highest mountain valleys (fig. 4). Interpolation of relative-age data (Kaufman and Hopkins, 1986; Kaufman and Calkin, 1988; Kaufman and others, 1988) demonstrates that at least one of these later advances is older than the last major interglacial period, yet all are far younger than the Nome River glaciation.

Between 20,000 and 14,000 years ago, during the last worldwide glaciation when Mount Osborn glaciers reached their maximum extent in the highest elevations, relative sea level on the Bering Sea shelf was lowered by about $90 \mathrm{~m}$ (Knebel and others, 1974). As a result, much of the vast Chukchi-Bering continental shelf was exposed as a low-lying plain covered by arctic-steppe vegetation and subjected to fluvial and glacial processes (Hopkins, 1982).

The latest and best studied rise in sea level over the Bering Sea shelf began about 16,000 years ago and was punctuated by several stillstands during which shorelines, preserved as submerged sand ridges, were developed (Nelson and Hopkins, 1972; Dupre, 1978; Nelson and others, 1982). By 15,500 years ago, the Bering Sea rose to within $50 \mathrm{~m}$ of its present level, breaching the Bering land bridge at Bering Strait (Hopkins, 1982; McManus and Creager, 1984). By 10,000 years ago, the Bering Sea flooded the shallow eastern Norton Sound, where it inundated a tundra peat cover (Nelson, 1982).

The changing depositional and erosional processes that operated over the northern Bering Sea during the Quaternary produced a patchwork of sediments that crop out on the present sea floor. The textural and compositional characteristics of the various deposits reflect a combination of several different sedimentary regimes (Venkatarathnam, 1971; Sharma, 1974; McManus and others, 1977). The lack of thick Holocene deposits on the floor of northern Bering Sea and the preservation of relict geomorphic features, including beach ridges, outwash fans, and stream valleys, suggest that bottom currents in northwestern Norton Sound are strong enough to prevent significant sediment accumulation, despite its proximity to the mouth of the Yukon River (fig. 1) (Nelson and Creager, 1977; Nelson and Nio, 1982). These strong currents also produce lag-gravel deposits by winnowing out fine-grained particles. In contrast, relict topography in south-central and eastern Norton Sound is obscured by a progradational wedge up to $18 \mathrm{~m}$ thick composed of Holocene mud, silt, sand, and organic-rich interbeds deposited in front of the modern Yukon River delta (Nelson, 1982).

\section{NEARSHORE SEDIMENTS OF THE NOME AREA}

\section{Seismic Stratigraphy}

The sedimentary stratigraphy within Norton Sound has been investigated using high-resolution, continuous seismic-reflection profiling (U.S. Bureau of Mines, 1967; Scholl and Hopkins, 1969; Grim and McManus, 1970; Tagg and Greene, 1973). These surveys indicate that Tertiary marine beds, represented by deep seismic reflectors, lap onto basement reflectors several kilometers offshore from Nome. The seismic data depict an unconformity separating nearly flat-lying beds from more steeply dipping underlying beds at depths ranging from a few meters near shore to about $100 \mathrm{~m}$ seaward. As early as 1913, F.H. Moffitt recognized that the buried marine beds dip more steeply than the overlying coastal plain deposits. This angular unconformity may represent a 
decline in the rate of subsidence of Norton basin (Tagg and Greene, 1973).

The unconformity described by earlier workers may correspond to the erosional contact between two seismic-stratigraphic units of presumed Quaternary age recognized by Hess (1985), who put forth the most complete and up-to-date interpretation of the shallow seismic stratigraphy of the northern Bering Sea. In Norton Sound, these units unconformably overlie a smooth and flat late Tertiary erosional surface. The lower of the two units, although composed dominantly of marine sediments, exhibits pervasive and complex fluvial reworking. This is particularly well displayed in the area of the bathymetric trough that parallels the southern coast of Seward Peninsula (fig. 1), where early fluvial activity may have been focused (Hess, 1985). Within the area of the bathymetric trough, the upper unit includes extensive deltaic deposits, apparently derived from an ancestral Yukon River that built out over disrupted sediment of the lower unit.
Deformation of the sedimentary sequence can be attributed to basinal-tectonic as well as glaciotectonic mechanisms. The sediments have been gently folded and locally faulted. Recent faulting is expressed as fault scarps on the sea floor; two in the Nome nearshore area have 1- to 2-m escarpments (Grim and McManus, 1970). Glaciotectonic deformation is exhibited locally offshore of Nome as distinctive coalescing seismic reflectors that are interpreted as thrusts and diapirs induced by overriding ice (Nelson and Hopkins, 1972).

A large, ancient buried delta was recognized in unpublished seismic-reflection records of the Nome nearshore area by Bert Barnes (then of the U.S. Bureau of Mines) and D.M. Hopkins (then of the U.S. Geological Survey). The delta extends several kilometers offshore from the mouth of Hastings Creek and consists of seaward-dipping, fine-grained marine sediments about $100 \mathrm{~m}$ thick. The ancient delta is disconformably overlain by horizontally bedded marine silt of late Cenozoic age. Sediment from boreholes reaching the uppermost part of

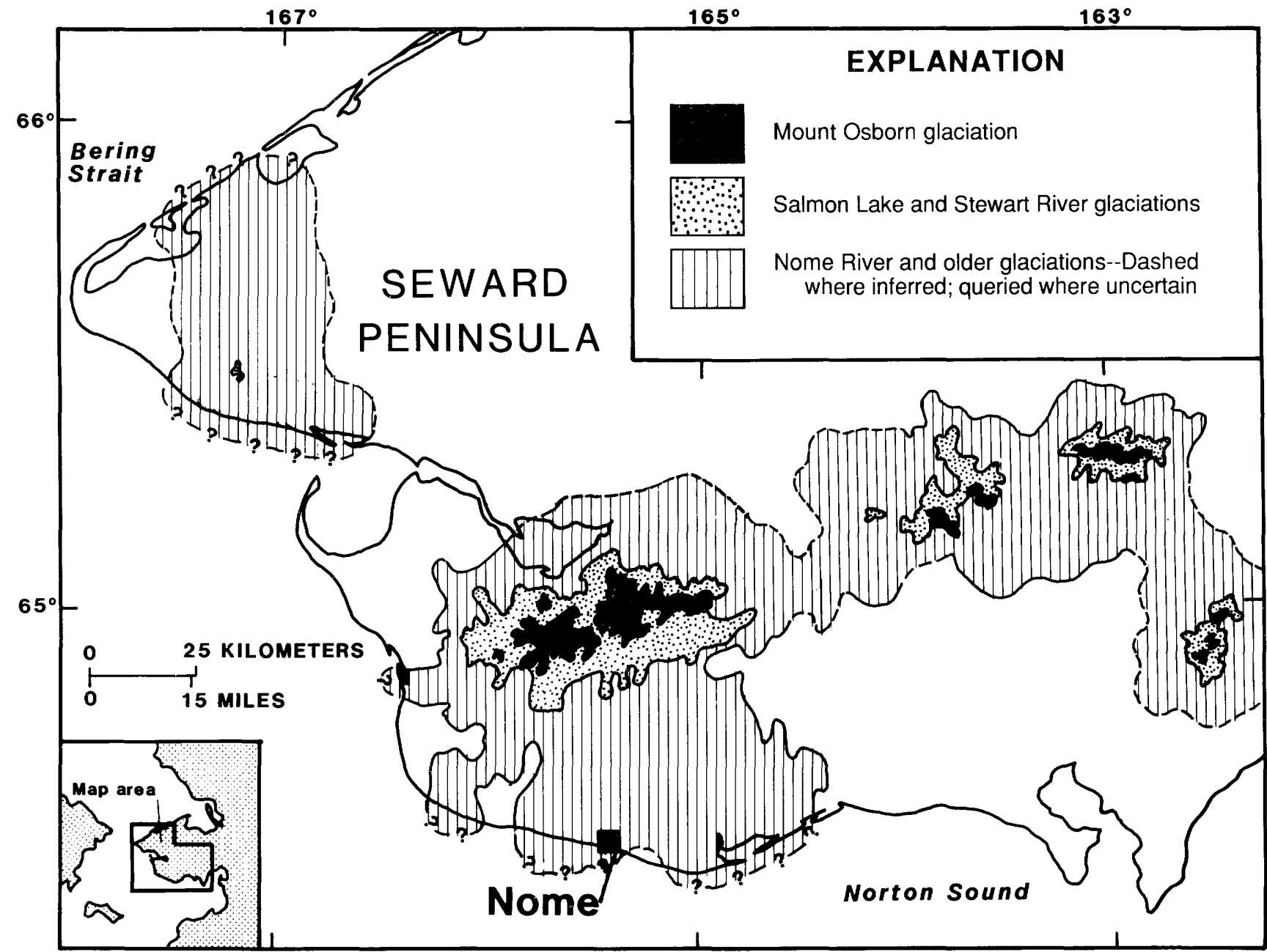

Figure 4. Limits of glacial advances on Seward Peninsula. Note vast extent of ice during Nome River and older glaciations in relation to younger glaciations (modified from Kaufman and Hopkins, 1986). Approximate limits of ice and, consequently, distribution of glacial deposits beyond southern coastline are inferred from sparse seismic and borehole data. 
the delta yielded pollen indicative of a Homerian (middle Miocene) age (J.A. Wolfe, U.S. Geological Survey, written commun., 1968). The top of the delta lies nearly $70 \mathrm{~m}$ below present sea level, suggesting that the northern coast of the Bering Sea lay near its present position as early as 10 million years ago. The Nome River may have once flowed east of its present course to provide the source for this large delta.

\section{Borehole Sediments}

Fifty-one boreholes, 30 to $75 \mathrm{~m}$ deep, were drilled offshore of Nome during the summer of 1967 as part of investigations conducted jointly by the U.S. Geological Survey (USGS) and U.S. Bureau of Mines (USBM) (fig. 5). A reverse-circulation hammer or oscillating drill was used to penetrate 2 to $3 \mathrm{~m}$ of sediment; at the base of each sampling interval, pressurized air and water forced the sediment slurry up to the surface through the inside of a double-walled, flush-jointed drill casing (Jenkins and Lense, 1967). Drill logs furnished by the USGS were incorporated in a draft report prepared by the former Marine Minerals Technology Center (U.S. Bureau of Mines, 1967) but never published. Drill logs include estimates of grain-size distributions from which the sediment was categorized into simplified textural classes (fig. 6).

The boreholes penetrated intercalated beds of heterogenous texture and composition (U.S. Bureau of Mines, 1967). Sixteen holes extended to bedrock where chloritic and graphitic schists and marble were encountered. These constitute the dominant lithologies in the overlying sediments, although granite and quartzite were present as well. Most of the sediments are overconsolidated and are composed of mixed particle sizes including sand and poorly rounded pebbles and cobbles in a matrix of silty clay. Drilling problems indicated that boulders were encountered as well. Secondary textures include rounded and sorted gravel, well-sorted sand, and organic-rich silt. Fragmented molluscan shells are scattered throughout the sediments with localized concentrations of complete valves found within sorted silty clay, primarily in the deeper parts of the section. The lithostratigraphy interpreted from the borehole logs is depicted in a series of schematic sections drawn perpendicular to the shoreline (figs. 5, 7). The sections illustrate the lack of stratigraphic continuity that makes correlations with seismic-stratigraphic units difficult.

\section{Origin of Sediments}

Some of the stratigraphic complexity of the Nome nearshore sediments may be an artifact of the crude borehole sampling procedure, and part may be attributed to the dynamic Quaternary geologic processes responsible for its deposition and subsequent deformation and reworking. Admixtures containing striated and faceted pebbles of exotic lithologies, such as those found only in the Kigluaik Mountains, can confidently be assigned a glacial origin, although they may have been subsequently

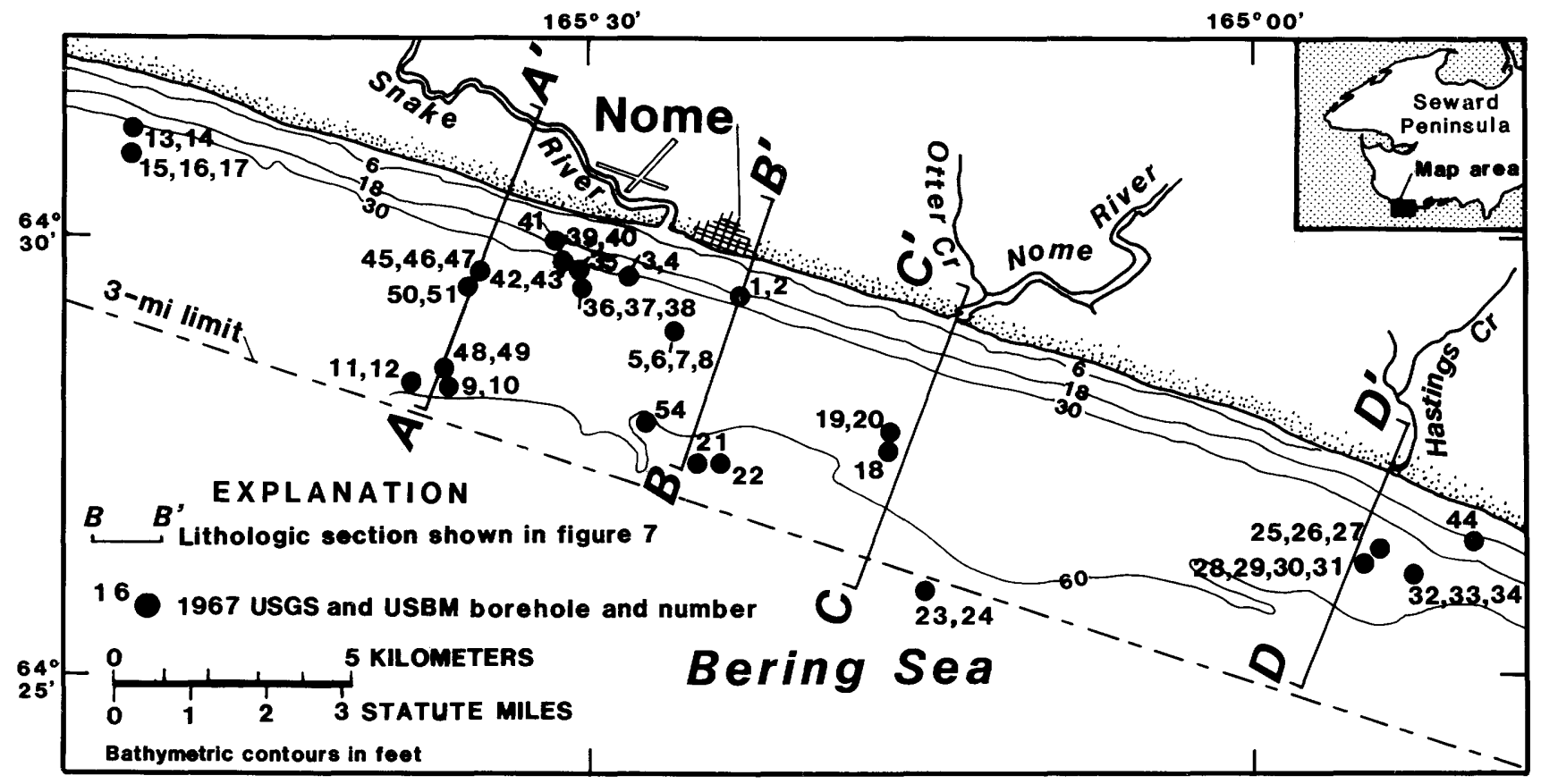

Figure 5. Locations of U.S. Geological Survey (USGS) and U.S. Bureau of Mines (USBM) boreholes drilled in 1967 (U.S. Bureau of Mines, 1967). Base from U.S. Geological Survey, 1:63,360, Nome B-1, C-1, and C-2 quadrangles, 1950. 
reworked. Glaciers advancing southward over the Nome nearshore area could have incorporated into their deposits large, discrete blocks of the underlying cohesive marine mud, producing the observed intercalated sequences of diamicton and sorted, fossiliferous silty clay. Further complexity was likely induced by glacial deformation at the former oscillating ice margin.

The spectacular exposures of glaciotectonically deformed Pleistocene marine and glaciogenic sediments on Baldwin Peninsula in the Kotzebue Sound region (fig. 1; McCulloch, 1967; Brigham-Grette and Hopkins, 1988; Huston and others, 1989), may provide an analog for at least part of the sediments of the Nome nearshore area. Exposures along the west shore of Baldwin Peninsula exhibit large-scale folding that juxtaposes fossiliferous marine silt and bouldery diamicton.

The close association of sediments displaying both marine and glacial characteristics in the Nome nearshore area can be attributed to characteristic glacial processes. Implicit in this mechanism is the assumption that by the time ice advanced onto the coastal plain, worldwide sea level had fallen to expose the marine sediments to glacial reworking. However, the timing of global sea-level fall in relation to early and middle Pleistocene glacial advances on Seward Peninsula is not known. A combination of glacial-isostatic, or ocean- and atmospheric-circulation effects may have permitted glaciers in the Bering Strait region to advance to open water when sea level was near its present position.

In the absence of a continuous sediment core, no complete sedimentologic interpretation of the offshore sediments can be made. However, striated pebbles found within fossiliferous marine silty clay may be interpreted as glacial ice-rafted debris, and poorly sorted silty gravel containing striated and erratic stones intermixed with marine molluscan shells (USGS-USBM, unpub. data, 1967) may represent ice-proximal glacial-marine sedi-

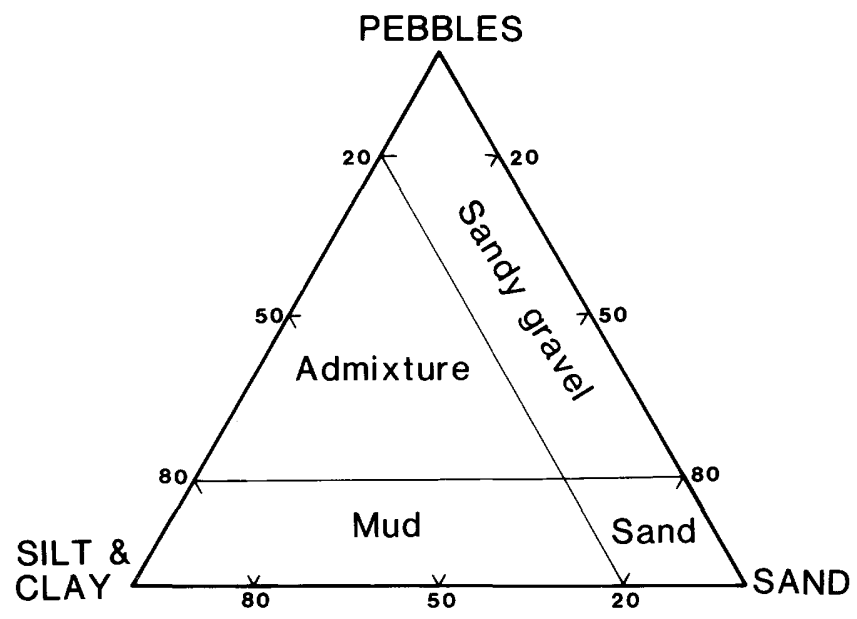

Figure 6. Fourfold classification scheme used in this report for sediment recovered from offshore boreholes. mentation. Whether the shells were incorporated into the glacial sediment from older marine units or deposited synchronously with the glacial debris has not been determined.

Although no emergent deposits exposed in the Nome area are interpreted as glacial-marine sediment, Petrov (1967; written commun. cited in Hopkins, 1973) described glacial-marine sediments within the Pinakul' and Kresta Suites of the Chukotsk Peninsula, northeast Siberia. Khoreva (1974) believed that these deposits are in part coeval with the Anvilian transgression. Preliminary work suggests that the shelly diamicton exposed on the east shore of Kotzebue Sound (Huston and others, 1989; Hopkins and others, 1989) may also be of early to middle Pleistocene glacial-marine origin. If correctly interpreted, these deposits indicate that the Nome River glaciation took place at a time of relative high sea level or that a large part of the continental shelves of the Bering and Chukchi Seas was depressed perhaps $100 \mathrm{~m}$ below its present level.

Indirect evidence of reconstructed ice extents and probable moisture sources is also consistent with the idea that glacial-marine sediments are present on the continental shelf adjacent to southwestern Seward Peninsula. Vast areas of the Chukchi-Bering platform supported glaciers during early to middle Pleistocene time (fig. 8; Hopkins, 1973). West of Seward Peninsula, a large ice cap centered over the Chukotsk Peninsula, northeastern Siberia, spread onto the continental shelf (Petrov, 1967; Creager and McManus, 1967; Silberman, 1969), far enough to encroach onto St. Lawrence Island (Hopkins and others, 1972). This ice cap may have coalesced with extensive glaciers originating in the low, rolling York Mountains of western Seward Peninsula (fig. 1) that have been described by Sainsbury (1967a, b) and Kaufman and Hopkins (1986). North of Seward Peninsula, large glaciers flowed from the western Brooks Range and coalesced in eastern Kotzebue Sound. Such tremendous volumes of ice in central Beringia undoubtedly had a significant isostatic effect. Whether the crustal depression was sufficient to offset the eustatic fall of sea level so that the northern shoreline of Bering Sea met the glaciers advancing onto the coastal plain at Nome is not known.

Nonetheless, the great extent of these early to middle Pleistocene glaciers is itself compelling indication that ice accumulated in central Beringia during a period of high worldwide or local sea level. Hopkins (1973) first proposed that the persistent submergence of the Bering shelf provided the moisture source necessary to generate the great mass of ancient glacier ice. The isostatic effects of ice buildup may have been secondary to phase relationships between ice advance in central Beringia and sea-level fluctuations in the world's oceans. The situation may have been somewhat analogous to that proposed for the Eastern Canadian Arctic, where Miller (1985) suggested that major glaciations occurred during the final 
stages of global interglacial events, presumably during periods of high-latitude insolation minima and relatively warm oceans.

\section{AMINOSTRATIGRAPHY}

Preliminary results of amino acid analyses, in progress at University of Colorado's Amino Acid Geo- chronology Laboratory under the direction of G.H. Miller, are used here to correlate stratigraphic units between onshore and offshore sites and to constrain the timing of major geologic events that dispersed and reconcentrated the particulate gold of the Nome area. The procedure for amino acid analysis involves the separation of the amino acid D-alloisoleucine (aIle) from its diasterisomer L-isoleucine (Ile); the ratio of these two amino acids (aIle/Ile) is a measure of the extent of amino acid
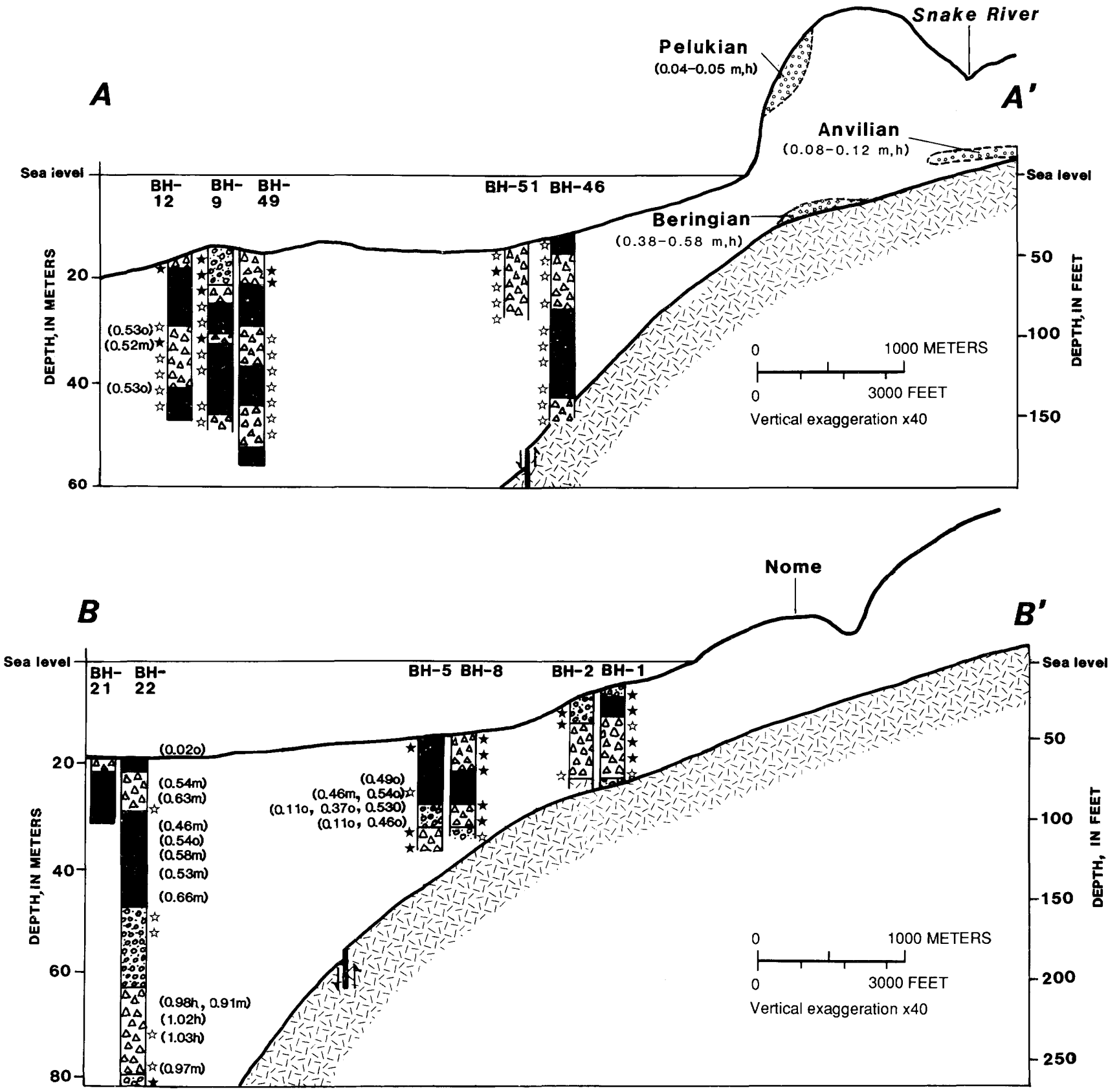

Figure 7. Schematic lithostratigraphy of the Nome nearshore area based on unpublished U.S. Geological Survey (USGS) and U.S. Bureau of Mines (USBM) well logs (see fig. 5 for locations of section lines and boreholes). Sea-floor and bedrock topography from U.S. Bureau of Mines (1967). Values in parentheses are mean amino acid ratios (alle/lle, total) measured in shells recovered from plotted depth. Relative gold content from USGS and USBM (unpub. data, 1967). Section $A-A^{\prime}$ shows onshore marine sediments of three transgressions. 
diagenesis and provides a value that is proportional to the age of the fossil (see Wehmiller, 1982, for a summary of stratigraphic and chronologic applications of amino acid analysis).

Amino acid ratios (alle/Ile, total amino acid assemblage) in molluscan shells recovered from the USGSUSBM boreholes are plotted alongside the lithostratigraphic columns in figure 7. Amino-acid diagenetic rates are similar in the molluscan genera Hiatella and Mya over the broad range of amino acid ratios measured in shells from the Nome area. Comparisons among other genera should be made with caution. Overall, the ratios range from 0.02 in several shells found near the sea-floor surface to 1.10 in shells recovered from near the base of several boreholes, about $50 \mathrm{~m}$ below the sea floor (fig. 9). Ratios measured in most shells from the upper $20 \mathrm{~m}$ of sediment range between 0.4 and 0.6 . Within this interval, ratios do not follow in stratigraphic order, suggesting that older shells have been reworked into younger sediment. Moreover, the entire range of values from 0.4 to 0.6 commonly co-occur within a single borehole-sample interval. This range of values is comparable to the range
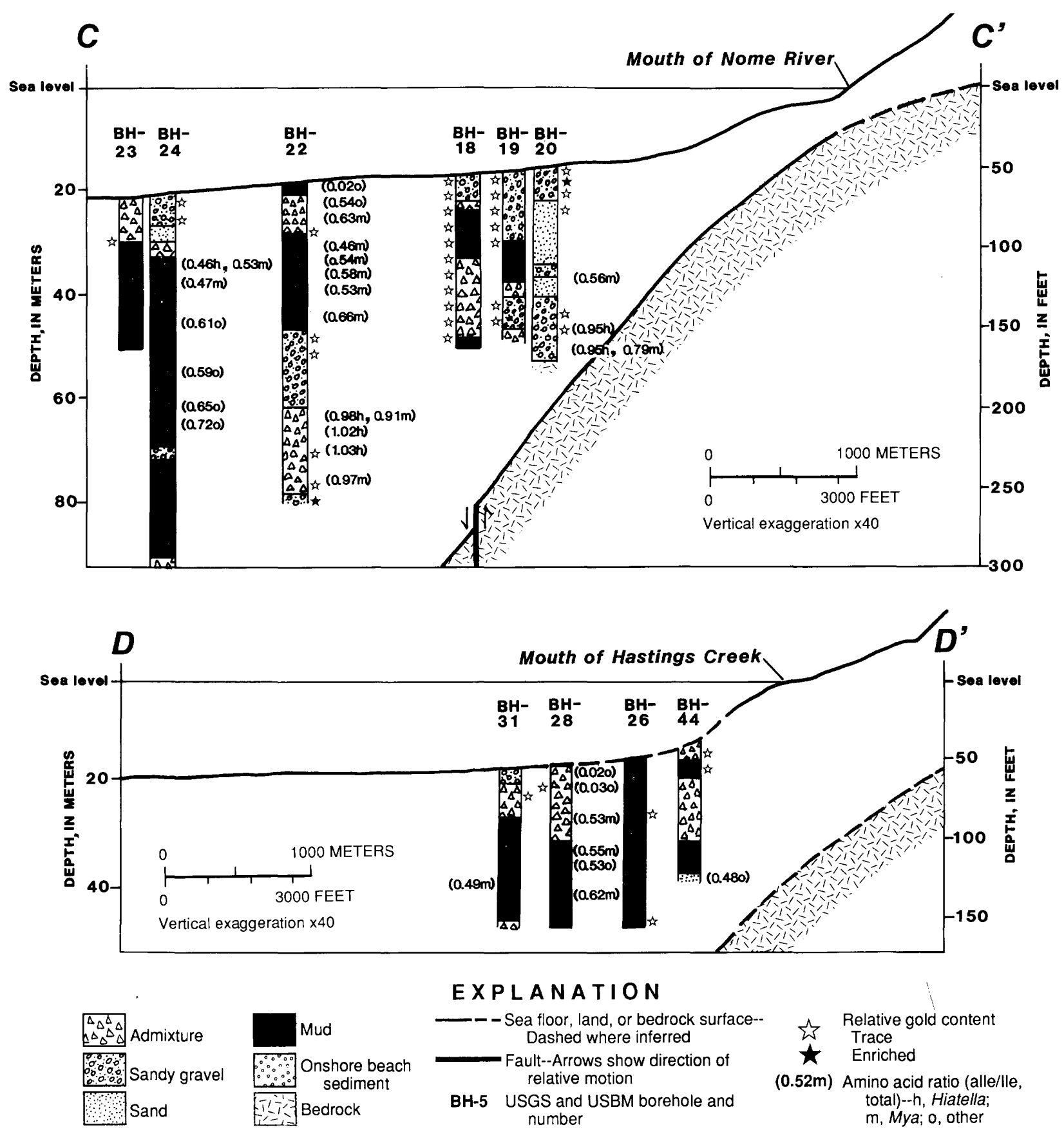

Figure 7. Continued. 
(0.38 to 0.58) measured in Hiatella and Mya shells from the type locality of the late Pliocene Beringian marine transgression (fig. 7, section $A-A^{\prime}$ ). Because amino acid ratios are dependent upon thermal conditions as well as age, though, the correlation between onshore and offshore ratios is presently not secure and awaits further study.

The broad range and mixed stratigraphic order of amino acid ratios measured in molluscan shells from the upper $20 \mathrm{~m}$ of sediment is indicative of considerable sediment reworking. Strong evidence of sediment reworking is further exemplified in USGS-USBM borehole 5 (fig. 7 , section $B-B^{\prime}$ ) in which several shells recovered from $15 \mathrm{~m}$ below the sea floor yield ratios of 0.11 and are overlain by redeposited sediment containing older molluscan valves with amino acid ratios clustering about 0.50 . The 0.11 ratios fall within the range of $0.08-0.12$ in Hiatella and Mya and are certainly no older than mollusks from the type locality of the Anvilian marine transgression. Therefore, the incorporation of older, reworked sediment into the top $15 \mathrm{~m}$ of borehole 5 took place after the Anvilian transgression. We cannot exclude the possibility that the younger shells were introduced into the lower sample intervals during the drilling operation. This is unlikely because (1) the inner casing was thoroughly flushed between samplings for recovery of gold, and (2) if introduced from above, the overlying sample intervals should contain younger shells, yet none has been found.

Below $20 \mathrm{~m}$, amino acid ratios increase more regularly and show fewer reversals with depth (fig. 9). Continuous deposition of sediments deeper than about

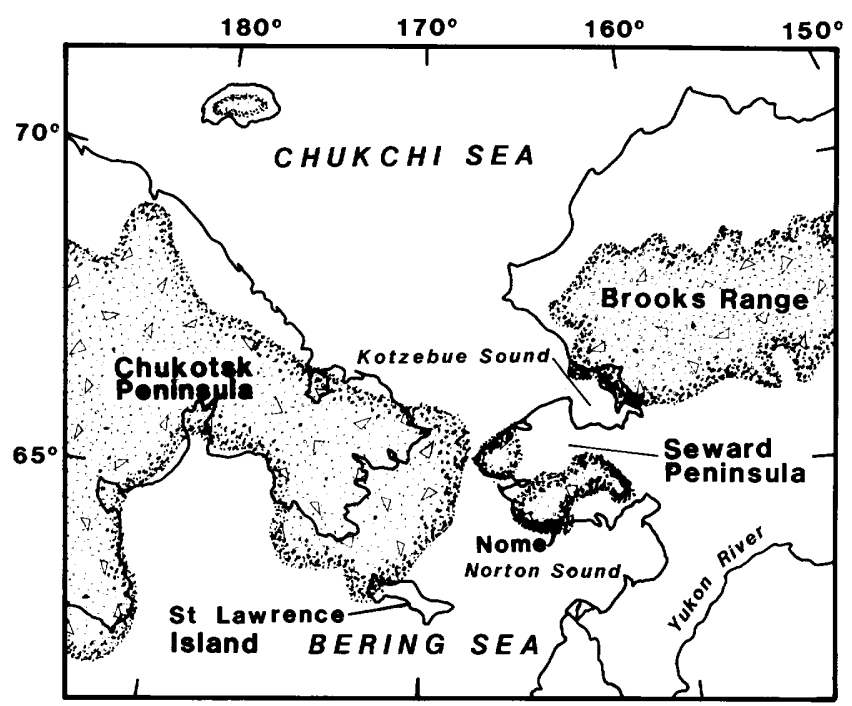

o 500 KILOMETERS

Figure 8. Approximate extent of early to middle Pleistocene glaciers (pattern) in central Beringia (modified from Hopkins, 1973).
$20 \mathrm{~m}$ below the sea floor is supported by a sharp decline in particulate-gold concentration below this level (fig. 10). The upper $20 \mathrm{~m}$ of nearshore sediment was enriched in particulate gold by reworking as well as through the input of gold-bearing debris carried by glaciers that advanced across mineralized zones of southwestern Seward Peninsula during the Sinuk and Nome River glacial intervals.

\section{GEOLOGIC CONTROLS ON PLACER-GOLD DISTRIBUTION}

In general terms, the distribution of placer-mineral concentrations is the product of interactions between primary sources and surficial geologic processes. This section focuses on surficial geologic controls of placergold dispersement and reconcentration. However, because placer-gold concentrations are typically found close to their source rock, even in glaciated terrains (Cobb, 1968; Lu and others, 1968), the distribution of possible source rocks must be considered.

The paucity of lode-gold sources on Seward Peninsula led Moffitt (1913, p. 128) to conclude that some of the rich placers were formed by the weathering of a great volume of rock containing a small amount of disseminated gold. Large amounts of gold may have been released during the intensive interval of Tertiary weathering indicated by deep weathering profiles found in central Seward Peninsula (Hopkins, 1963). Gold-bearing deposits of Tertiary age are known on Seward Peninsula (Hopkins and others, 1971; Yeend and others, 1988) where, as at other locations in Alaska, they may have been reworked to form younger deposits with enriched concentrations (Yeend, 1984).

Brooks (1908, p. 122) emphasized the association of limestone-schist contacts with gold-bearing lodes and placer-gold deposits. His early theory is supported by a recent study of eight placer-gold-producing districts of Seward Peninsula, in which Yeend and others (1988) found a strong spatial association between bedrock type and placer-gold resources. As in the Nome district, all of the placer areas are underlain by low-grade metamorphic rocks divisible into several mappable lithostratigraphic units. Exposures of the mixed unit of Till and others (1986), dominated by quartz-graphite schist and marble, are common to all areas. This bedrock unit is the most likely source of gold on Seward Peninsula.

Gold of placer deposits is typically of chemical as well as detrital origin (Boyle, 1987, p. 540). The chemical processes of solution, migration, and reprecipitation of gold in auriferous deposits is complex and beyond the scope of this report.

\section{Quaternary Geologic Processes}

Global climate fluctuations of the Quaternary have furnished ideal conditions for placer formation by regu- 
lating geomorphic processes that alternate between erosion and deposition (Sutherland, 1985). In the Nome area, the distribution and nature of placer deposits are controlled by Quaternary geologic factors, including glacial erosional, depositional, and deformational processes; sea-level fluctuations; marine shoreline and nearshore processes; fluvial processes; faulting and subsidence. Figure 11 presents a conceptual framework for the intricate relation between these geologic factors and the distribution of placer gold.

\section{Glacial Processes}

Glacier ice is an effective agent of erosion and transport; it can produce and indiscriminately carry large

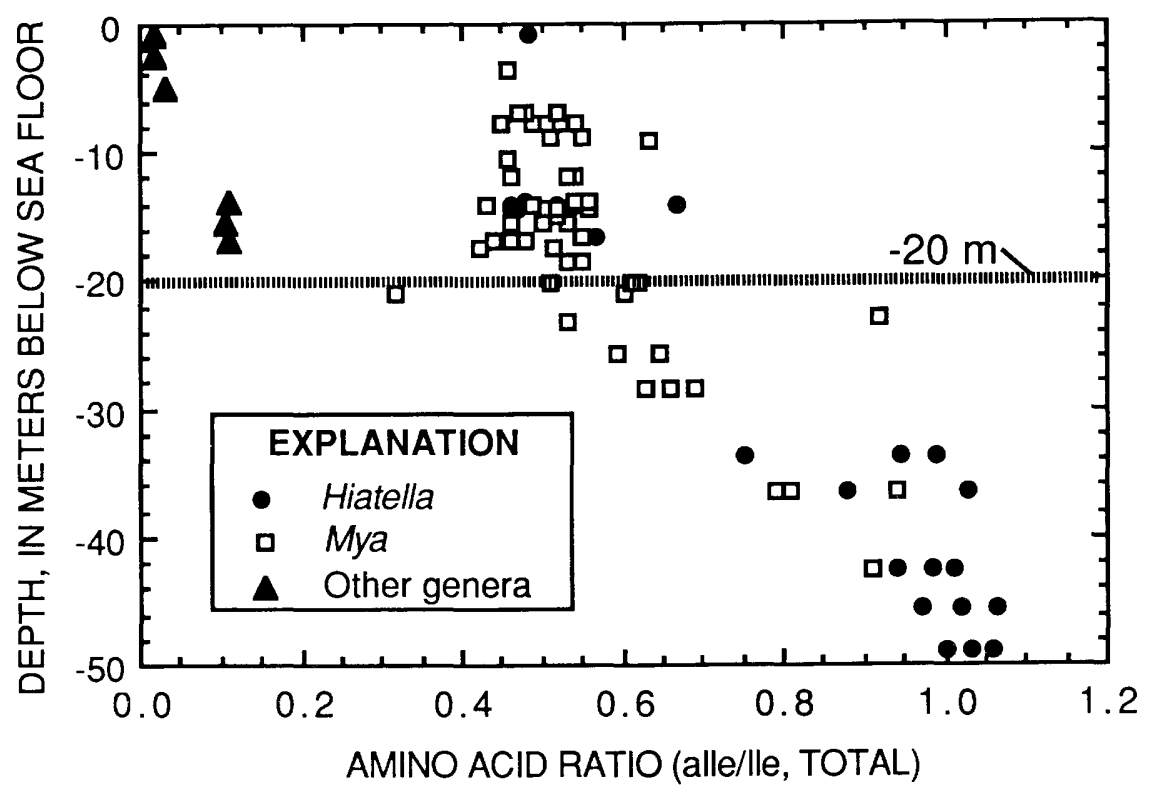

Figure 9. Preliminary results of amino acid analyses on molluscan shells from 1967 U.S. Geological Survey and U.S. Bureau of Mines boreholes plotted by depth. Data are in part from D.M. Hopkins (University of Alaska, unpub. data, 1984) and G.H. Miller (University of Colorado, INSTAAR, unpub. data, 1984).

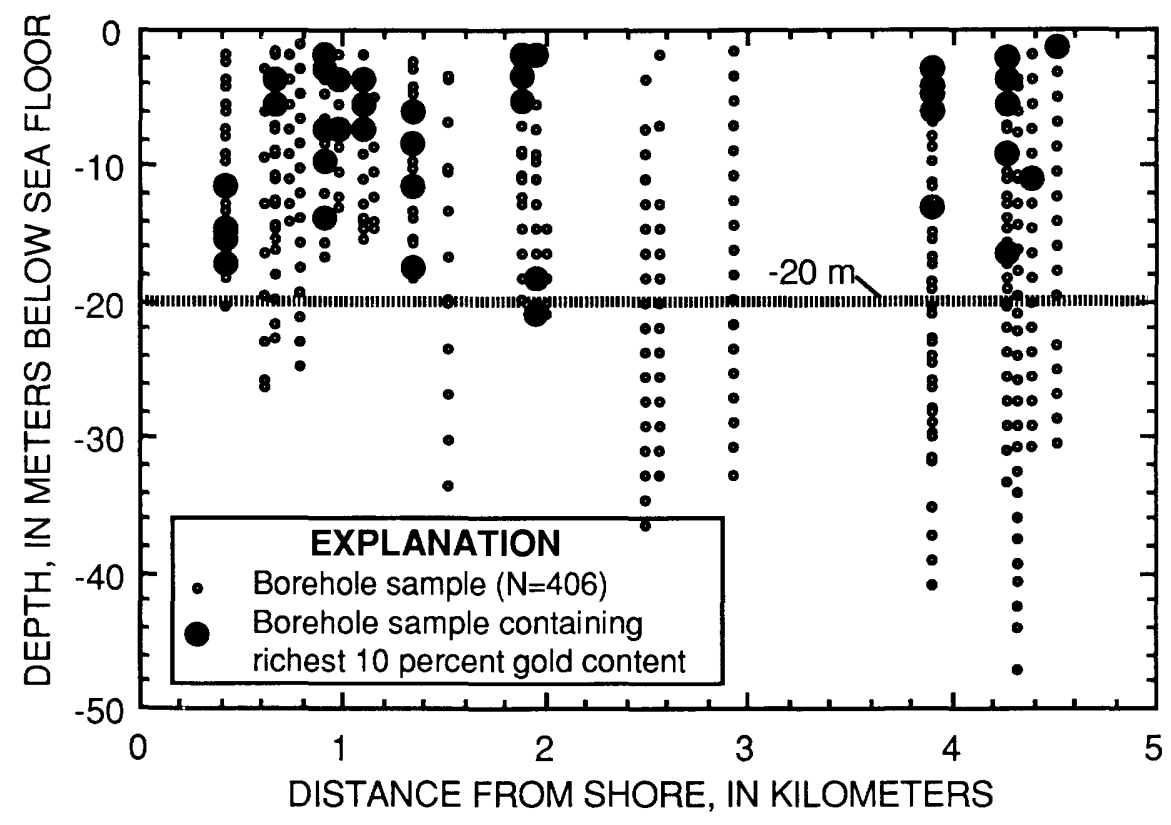

Figure 10. Vertical and seaward distribution of borehole sampling intervals showing locations of intervals that contain enriched gold concentrations (highest 10 percent of all values; from U.S. Geological Survey and U.S. Bureau of Mines, unpub. data, 1967). 
volumes of poorly sorted sediment. At the margins of the glacier, the sediment is readily reworked by great discharges of glacial meitwater that concentrate heavy minerals in channels cutting through auriferous till. The abundant coarse constituents of glacial debris provide an ideal substrate for entrapment of heavy-mineral grains between larger framework particles, a mechanism that Reid and Frostick (1985) show to be especially important.

Geologic controls on the distribution of placer gold in the Nome area were discussed by Nelson and Hopkins (1972). They advocate that glaciers played the principal role in eroding gold from source rocks and weathered debris and redistributing it onto the coastal plain during what they believed were periods of lowered sea level. The gold was subsequently reconcentrated from the till by marine and fluvial activity. Their model accounts for the strong correspondence between the distribution of till and heavy-mineral enrichments, including gold (Hopkins, 1968) and mercury-bearing minerals (Nelson and others, 1972).

Because the early glaciers that advanced over the Nome area may have terminated in the marine environment, both glacial-terrestrial and glacial-marine depositional models for the nearshore sediments must be considered (fig. 12). The implications of these two models to offshore gold distribution and resource potential are fundamentally different. For the terrestrial model, particulate gold is not expected to travel more than several kilometers in outwash streams. In the glacialmarine model, on the other hand, ice rafting and submarine debris flows may distribute gold greater distances beyond the glacier terminus. Where a sea-floor rise is present, such as a morainal ridge located at a former, more extensive ice position, ice-rafted debris will accumulate under the grounded bergs.

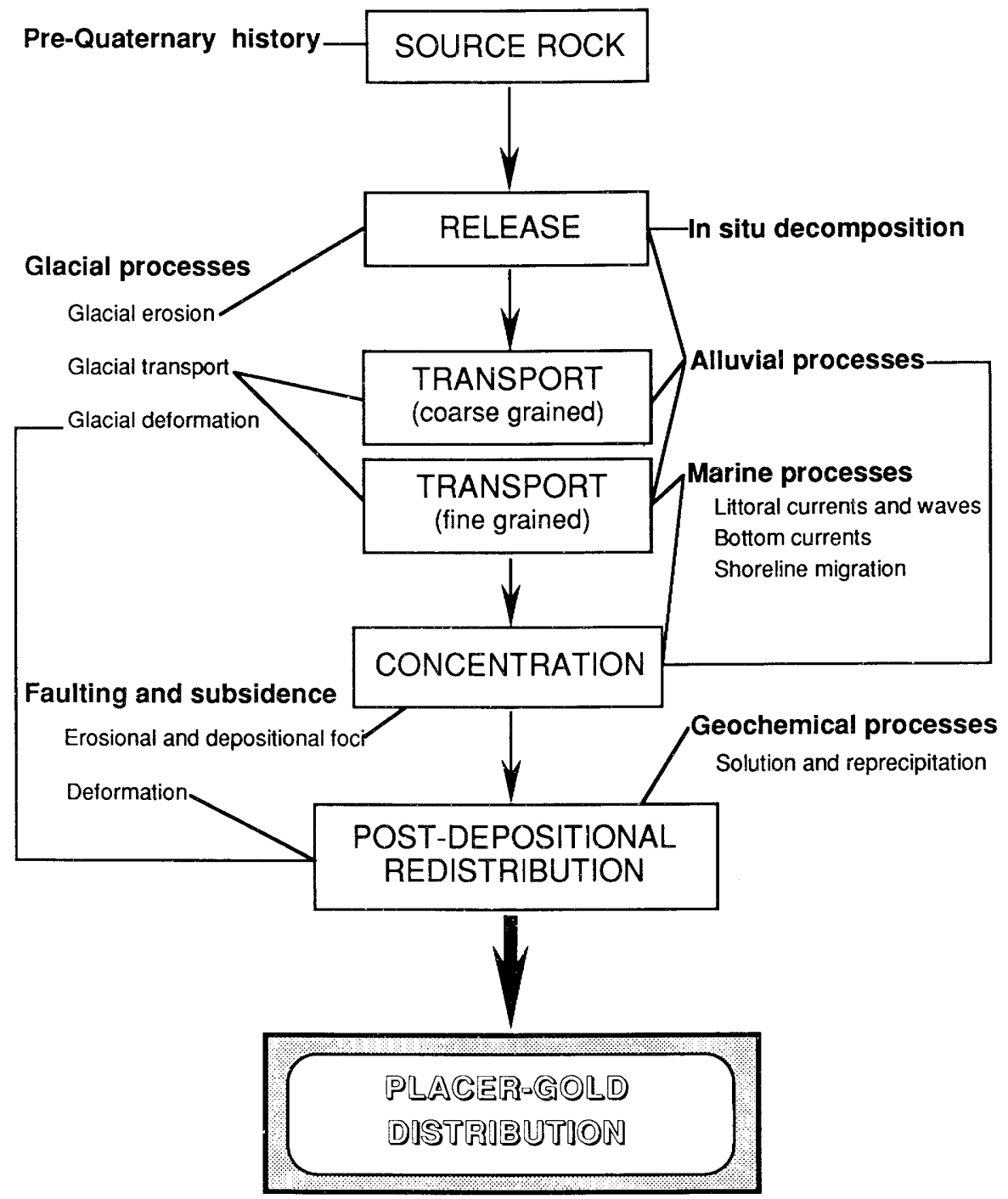

Figure 11. Conceptual framework for relation between geologic processes and placer-gold distribution. 


\section{Marine Processes}

Nearshore and coastal areas of Norton Sound are strongly affected by storm-generated currents and waves (Nelson, 1978; Larsen and others, 1981). In the Nome area, bottom currents flow intermittently at speeds of up to nearly 2 knots (100 cm per second), moving in either direction parallel to the coast (Nelson and Hopkins, 1972). The ability of these episodically strong bottom currents to winnow the sea-floor sediments and concentrate heavy minerals is augmented by the repeated migration of shoreline, and its accompanying high-energy littoral zone, over the continental shelf of the northern Bering Sea during eustatic fluctuations of Pleistocene seas. In this manner, both wave and current activity have reworked considerable volumes of material over broad areas of the sea floor. Lag concentrates formed by this process have been described on the Canadian continental shelf (Emery-Moore and others, 1988; Hein and Syvitski, 1988) and over much of the shallow Bering Sea (McManus and others, 1977).
Within the dynamic shoreline zone, stormgenerated waves play a principal role in forming beach placers. Because they break close to the beach with high frequency, storm waves are particularly effective in mobilizing beach sediment. During high-wave activity, coarser particles and heavy minerals are left in the upper beach zone as a lag deposit (Komar and Wang, 1984). During quiescence, constructional beach sediments containing minor concentrations of heavy minerals are deposited over the basal-lag deposits. Then, seasonal climatic changes bring storm surges that, once again, destroy the beach and further expand the heavy-mineral lag. Thus, the alternation between destructive and constructive conditions is responsible for the development of the richest concentrations in beach placers (Sutherland, 1987). Such lag deposits have been described from the emergent beaches near Nome (Moffitt, 1913), where they form lenticular pay streaks parallel to the shore (fig. 3). The sand composing and, especially, the wave-washed gravel underlying these beaches are enriched in gold derived from both the wave reworking of underlying gold-bearing
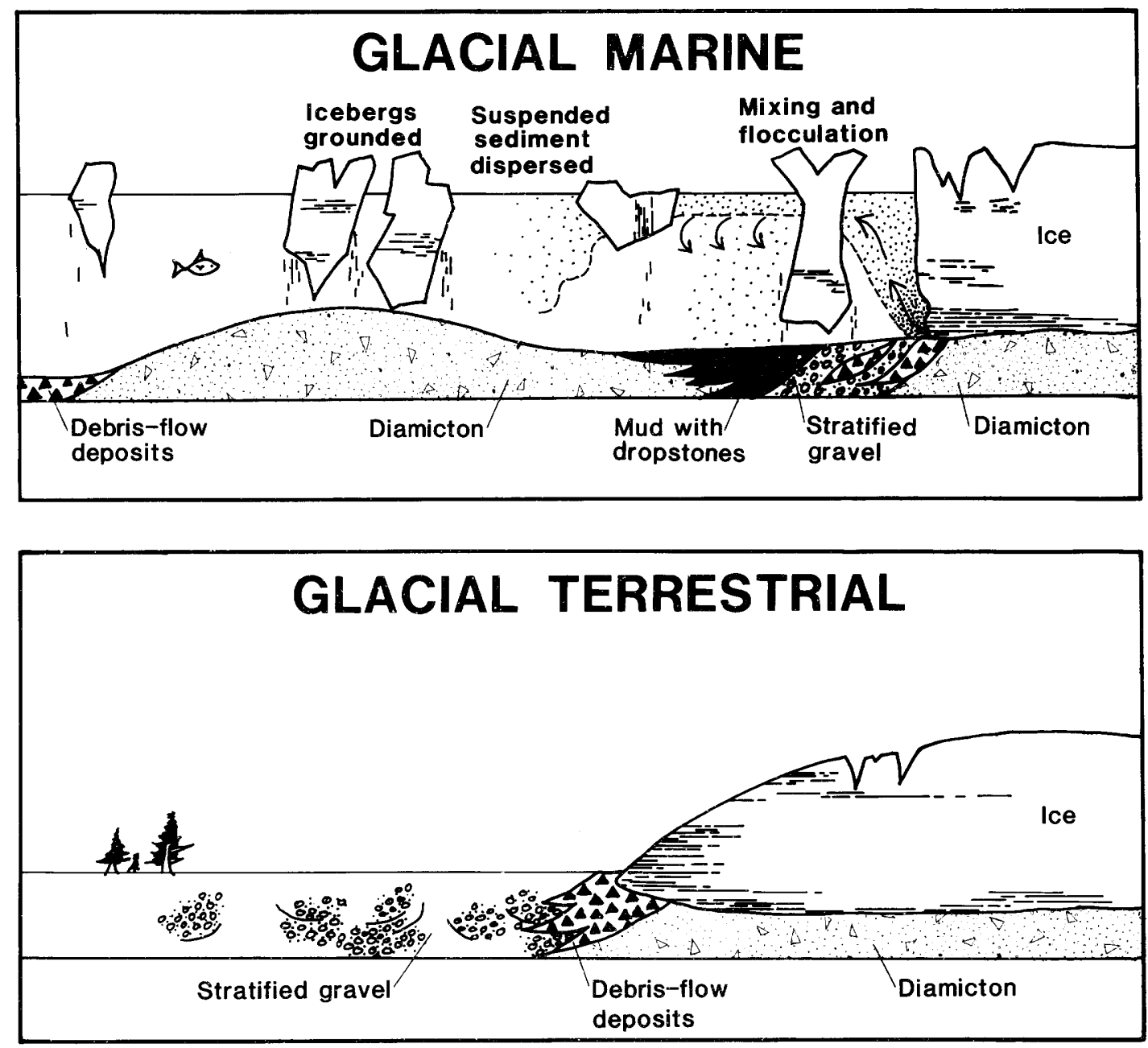

Figure 12. Two alternative models for depositional environment of sediments offshore of Nome. Glacial-marine model modified from Boulton and Deynoux (1981). 
till and from contemporaneous stream input, as indicated by the intercalation of auriferous fluvial and marine sediments near the mouth of Anvil Creek (fig. 3; Moffitt, 1913).

Sutherland (1987) identified two general shoreline locations where heavy minerals, particularly fine-grained gold, are preferentially concentrated. The first is the area of coast that receives a maximum amount of wave energy. Here, sediment fluxes are high, and particles that are stable in all but the highest energy events are retained while finer particles are removed. Accordingly, there is a net gain in the coarsest or hydraulically equivalent higher density particles undergoing longshore transport. The second location is where transport energy is reduced, causing preferential deposition of heavy minerals while less dense particles continue along shore.

The configuration of the coast is important in localizing heavy-mineral deposits (Jones and Davies, 1979; Sutherland, 1987). Headlands obstruct longshore drift, causing heavy minerals to be retained in the highenergy zone immediately updrift of the headland, while lighter minerals are passed around the headland. This process has operated on a variety of scales in forming the emergent beach placers near Nome, where mining activities revealed gold concentrations along the west-facing side of shoreline indentations and bedrock projections (Moffitt, 1913, p. 116).

\section{Fluvial Processes}

Because the finer grain size fraction of bedload is enriched in heavy-mineral grains, it tends to remain on the stream bed while larger, lighter grains protruding into the current are preferentially entrained (Reid and Frostick, 1985). This effect is augmented by the high specific gravity of placer minerals that require larger forces to be dislodged. The combination of winnowing and inertia-controlled processes, working with cyclic response of fluvial systems to climatic changes or intermittent tectonism, create ribbon-shaped lag deposits that fill etches on underlying erosional surfaces. Fluvial-placer deposits of this type are common on Seward Peninsula and elsewhere around the world. At Nome, concentrations of coarse-grained gold roughly define old drainage lines, despite subsequent dispersal and reworking by wave and glacial activity (Tuck, 1968).

During intervals of eustatically lowered sea level, ancient streams graded to lower base levels incised and reworked preexisting sediments that mantle the continental shelf of the northern Bering Sea. Seismic profiling in Norton Sound reveals an extensive network of both surficial and deeply buried ancient channels (Greene, 1970; Grim and McManus, 1970; Tagg and Greene, 1973; Hess, 1985). The ability of ancient streams to have concentrated placer gold is dependent not only upon their hydraulic characteristics and the extent to which their channels migrated, but also on the gold content of the source material through which they eroded. Nelson and Hopkins (1972, p. 24) indicated that stream-bottom alluvium containing coarse-grained gold is restricted to areas floored by till. Furthermore, they stated that the ancient streams that crossed till apparently did not carry gold any great distance beyond the glacial debris, just as coarse placer gold in present-day Arctic streams is not transported more than 3.0 to $4.5 \mathrm{~km}$ from its source (Tuck, 1968).

\section{Faulting and Subsidence}

The location of erosional sites favorable for reworking of sediment, as well as depositional centers where sediment continuously accumulates, is controlled by faulting and subsidence. The apparent cessation of crustal subsidence of Norton Sound in the late Pliocene transformed the Nome nearshore area from a depositional center into a site of sediment transport and erosion. The development of a seaway through Bering Strait aided in reducing sediment accumulation in the nearshore area by moving most of the sediment entering Norton Sound onward to the Arctic Ocean (McManus and others, 1974).

The location of fault scarps that cut the present or a former sea floor is of particular interest in the offshore area where headlands do not obstruct currents (Tagg and Greene, 1973; Thor and Nelson, 1980). By regulating the rate of shoreline migration, these scarps may have controlled the position of beach-ridge deposition (for example, see figure 5 of Nelson and Hopkins, 1972). More importantly, they localize wave activity and provide a geomorphic trap for concentrating heavy minerals. Whether any of the offshore faults are associated with primary mineralization is not known. However, one fault zone offshore of Nome was penetrated by a borehole extending several meters into fault-gouge material, all of which was barren of gold (USGS-USBM, unpub. data, 1967).

Recent tectonism in Norton Sound has produced a series of northwest-trending horst and graben features (Johnson and Holmes, 1980). The uplifted blocks may have been sites of intensified sediment reworking that produced heavy-mineral enrichments, such as the goldrich relict sediments found on topographic highs over glacial till (Nelson, 1971).

\section{RESOURCE POTENTIAL}

In their appraisal of placer-gold resources offshore of Nome, Nelson and Hopkins (1972) found the richest concentrations and coarsest particles of gold in sea-floor 
lag gravel mantling glacial till, in basal gravel deposits of ancient stream valleys cutting the auriferous till, and in gravel patches over bedrock. Lag-gravel deposits formed on till contain gold concentrations typically 10 times greater than background value; in places, enrichments of approximately $2.2 \mathrm{~g} / \mathrm{m}^{3}$ have been reported (Nelson and Hopkins, 1972). Gold enrichments of this magnitude represent sediment deflation on the order of 1.5 to $2.5 \mathrm{~m}$. The gold is predominantly coarse grained $(>1.0 \mathrm{~mm})$ and resistant to transport by even the strongest currents measured offshore. Interestingly, however, the same relict gravel contains low concentrations of other heavy minerals with specific gravity low enough to be moved by strong bottom currents while gold is left behind (Sheth, 1971).

Tagg and Greene (1973) delineated six tracts in the Nome nearshore area most favorable for placer-gold enrichment based on the presence of buried channels and beach ridges and proximity to till. Typical gold concentrations in this area are reported to range between 0.49 and $0.65 \mathrm{~g} / \mathrm{m}^{3}\left(0.012\right.$ and 0.016 troy oz/yd $\mathrm{d}^{3}$; U.S. Office of Technology Assessment, 1987). Very little is known about the distribution of source material outside of the area directly offshore of Nome.

The spatial distribution of placer gold, especially coarse-grained particles ( $>1 \mathrm{~mm})$, is strongly dependent upon the location of source material. Fine-grained gold is more widely dispersed and may form significant localized concentrations in areas distant from source material. Seismic profiles were used to delineate the extent of till and outcropping-bedrock areas that may be contributing gold in the Nome nearshore area (U.S. Bureau of Mines, 1967; Tagg and Greene, 1973). Bedrock intersects the sea floor near the western limb of the Snake River valley trough (fig. 3) and in the Sledge Island area (fig. 1), where coarse-grained gold is found on the sea floor (Nelson and Hopkins, 1972). End moraines were delineated about $5 \mathrm{~km}$ beyond the coast at Nome and west of Nome beyond the mouth of the Sinuk River (Nelson and Hopkins, 1972; Tagg and Greene, 1973). However, unlike their broad, voluminous onshore counterparts, these moraines are not raised topographic features that characterize glacial-terrestrial ice-marginal deposits. Coarsegrained gold found in surface samples beyond the inferred moraines (Nelson and Hopkins, 1972) indicates that mass transport of gold-bearing sediments extended beyond these limits. Whether these coarse-grained particles were derived in situ from source material or rafted in by sea ice is not known. The presently mapped limit of till may represent a former glacier grounding line. If the glacial advance took place at a time of high relative sea level, submarine debris flows would have discharged from this position, depositing digitate lobes of poorly sorted sediment, including coarse-grained gold, many kilometers seaward. Icebergs calving from the glacier terminus would have dispersed gold-bearing debris into
Norton Sound, where the sediment would have accumulated on sea-floor rises that trapped the icebergs.

Within the area sampled by the USGS-USBM boreholes-a narrow tract roughly coinciding with the inferred limits of till-there is apparently no seaward decline in gold concentration within the upper $20 \mathrm{~m}$ of sediment (fig. 10). The vertical distribution of gold, however, is less regular (fig. 13) and is apparently correlated with sediment grain size (fig. 7). Overall, the greatest enrichments are found within the uppermost $2 \mathrm{~m}$ of sediment. When only the richest 50 percent of the intervals are considered, the greatest concentrations occur 2-4 m below the sea-floor surface; a secondary enrichment is found at approximately $18 \mathrm{~m}$ depth. These subsurface horizons, marked by enrichments of heavy minerals, may represent buried erosional surfaces analogous to the present sea floor. With additional amino acid analyses of molluscan shells, it will be possible to test this hypothesis by identifying the position of disconformities that may record periods of sediment reworking. Gold enrichments are expected along surfaces between adjacent, perhaps lithologically identical, units containing mollusks with dissimilar amino acid ratios.

Although the bulk of the gold recovered in the USGS-USBM boreholes is contained within the upper 20

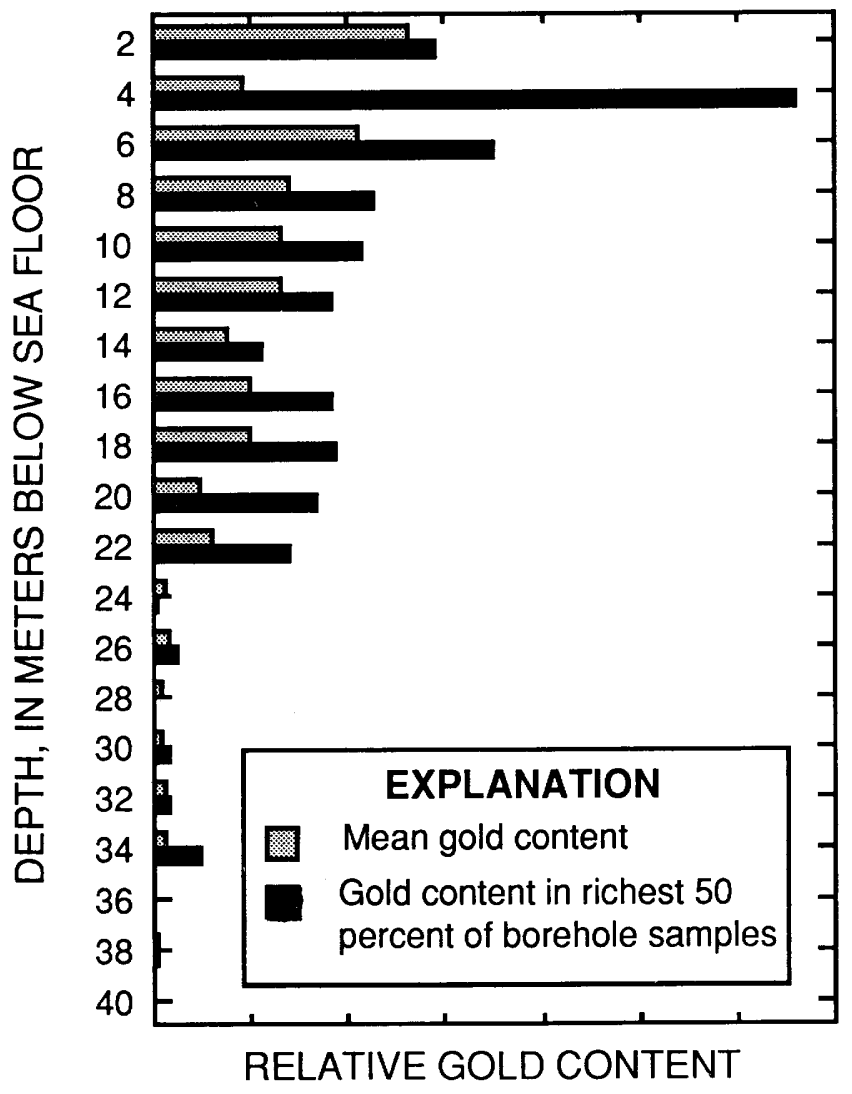

Figure 13. Relation between gold content and depth in U.S. Geological Survey and U.S. Bureau of Mines boreholes (from U.S. Geological Survey and U.S. Bureau of Mines, unpub. data, 1967). 
$\mathrm{m}$ of section, particulate gold is present in minor concentrations at depths up to $30 \mathrm{~m}$ below this level. Molluscan shells from these depths yield amino acid ratios that are much higher $(>1.0)$ than the Beringian ratios, and fossil pollen from this level records a nearby coniferous forest with spruce, pine, and fir represented (D.M. Hopkins, University of Alaska, unpub. data, 1968). These preBeringian sediments predate the oldest emergent glacial deposits on Seward Peninsula. The gold found within the lower marine section was most likely derived from streams that carried gold to the sea and from the direct release of gold from submarine sources including mineralized bedrock and the thick in situ regolith developed during the postulated interval of prolonged subaerial Tertiary weathering. This possible source is now insulated from the sea-floor surface by a seaward-thickening wedge of late Cenozoic marine and continental deposits.

\section{CONCLUSIONS}

A multitude of late Cenozoic geologic processes are reflected in the stratigraphic complexity and sedimentologic diversity of deposits recovered in the 1967 USGS-USBM boreholes and depicted in seismic profiles of the Nome nearshore area. The extent of amino acid diagenesis in fossil molluscan shells indicates that the Nome nearshore area received continuous marine sedimentation during the late Tertiary. A dramatic sedimentologic change is recorded at about $20 \mathrm{~m}$ depth in the boreholes. This level apparently coincides with the time of the Beringian marine transgression, when continuous deposition was replaced by intensive sediment reworking. Following the Beringian transgression, fluctuating sea levels, migrating river channels, advancing glacier ice, and jostling crustal blocks have repeatedly replenished, reworked, and deformed the sediments. These interacting processes governed the distribution of particulategold concentrations in the upper $20 \mathrm{~m}$ of offshore sediment and on bedrock or in beach sediments onshore.

Data from the USGS-USBM 1967 boreholes indicate that, within the area extending approximately $5 \mathrm{~km}$ seaward of Nome, gold values in the top $20 \mathrm{~m}$ of sediment do not decrease seaward. The greatest concentrations are found within the uppermost $4 \mathrm{~m}$ of the sea-floor deposits. Erosional surfaces, marked by goldenriched lag-gravel deposits analogous to those blanketing the present sea floor, may be buried within the sequence of Quaternary deposits. Because the distribution of gold concentrations and glacial deposits are strongly related, the extent of former glaciers is fundamental to the resource potential of offshore sediments. The presently mapped limit of till in the Nome nearshore area may represent a glacier grounding line from which submarine debris flows and icebergs where discharged carrying gold-bearing debris into northern Norton Sound.
Beginning with the turn of this century, geologic studies of the Nome coastal plain have furnished information on the major late Cenozoic geologic events of the region. However, the stratigraphy and placer-gold content of sediments mantling the adjacent continental shelf remain largely unknown, and at present, can only be inferred from theoretical considerations and past investigations concentrated in the Nome nearshore area. The geology and resource potential outside of this area are even more speculative. An accurate appraisal of the placer-gold resources in the offshore sediments awaits further exploration. Sedimentologic studies aimed at determining more precisely the mechanisms by which the auriferous sediments have been transported, deposited, and reworked will greatly improve our predictive models of gold distribution.

\section{ACKNOWLEDGMENTS}

Gifford H. Miller (University of Colorado) provided the direction and laboratory facilities at the Institute of Arctic and Alpine Research to complete the amino acid analyses. Primary funding for this study was provided by the U.S. Minerals Management Service through contract 1412-0001-30460 to Kaufman.

\section{REFERENCES CITED}

Boulton, G.S., and Deynoux, M., 1981, Sedimentation in glacial environments and the identification of tills and tillites in ancient sedimentary sequences: Precambrian Research, v. 215 , p. $397-421$.

Boyle, R.M., 1987, Gold-History and genesis of deposits: New York, Van Nostrand Reinhold, 676 p.

Brigham, J.K., 1985, Marine stratigraphy and amino acid geochronology of the Gubik Formation, western Arctic Coastal Plain, Alaska: Boulder, University of Colorado, Ph.D. dissertation, $316 \mathrm{p}$.

Brigham-Grette, J., and Hopkins, D.M., 1988, Stratigraphy of glacially tectonized marine sediment and diamicton on Baldwin Peninsula, Kotzebue Sound, western Alaska [abs.]: American Quaternary Association, program and abstracts of the tenth biennial meeting, p. 111.

Brooks, A.H., 1908, The gold placers of parts of Seward Peninsula, Alaska: U.S. Geological Survey Bulletin 328.

Carter, L.D., Brigham-Grette, J., and Hopkins, D.M., 1986, late Cenozoic marine transgressions of the Alaskan Arctic Coastal Plain, in Heginbottom, J.A. and Vincent, J.S., eds., Correlation of Quaternary deposits and events around the margin of Beaufort Sea: Geological Survey of Canada Open-File Report 1237, p. 21-26.

Cobb, E.H., 1968, Metallic mineral resources map of the Nome quadrangle, Alaska: U.S. Geological Survey Open-File Report, $12 \mathrm{p}$.

Creager, J.S., and McManus, D.A., 1967, Geology of the floor of the Bering and Chukchi Seas-American studies, in Hopkins, D.M., ed., The Bering land bridge: Stanford, Calif., Stanford University Press, p. 7-31. 
Dupre, W.R., 1978, Yukon delta coastal processes study: NOAA, U.S. Department of Commerce, environmental assessment of the Alaskan Continental Shelf, annual report of principal investigators for the year ending March 1978, v. 11, p. 384-446.

Emery-Moore, M., Barrie, J.V., and Solomon, S., 1988, Modelling of two heavy mineral placer deposits on the Canadian continental shelf: Geological Society of Canada Annual Meeting, Program with Abstracts, v. 13, p. A37.

Fisher, W.A., Patton, W.W., Jr., and Holmes, M.L., 1982, Geology of Norton Basin and continental shelf beneath northwestern Bering Sea, Alaska: American Association of Petroleum Geologists Bulletin, v. 66, p. 255-285.

Greene, H.G., 1970, A portable refraction seismograph survey of gold placer areas near Nome, Alaska: U.S. Geological Survey Bulletin 1312-B, 29 p.

Grim, M., and McManus, D.A., 1970, A shallow seismicprofiling survey of the northern Bering Sea: Marine Geology, v. 8, p. 293-320.

Hein, F.J., and Syvitski, J.P.M., 1988, Evolution of Sept Iles delta complexes and shallow marine placer, north shore of Gulf of St. Lawrence, Quebec: Geological Society of Canada Annual Meeting Program with Abstracts, v. 13, p. A54.

Herman, Y., and Hopkins, D.M., 1980, Arctic oceanic climate in late Cenozoic time: Science, v. 209, p. 557-562.

Hess, R.G., 1985, Quaternary stratigraphy and sedimentationNorthern Bering Sea, Alaska: Stanford, Calif., Stanford University, Ph.D. thesis, 89 p.

Hopkins, D.M., 1959, Cenozoic history of the Bering land bridge: Science, v. 129 , p. 1519-1528.

1963, Geology of the Imuruk Lake area, Seward Peninsula, Alaska: U.S. Geological Survey Bulletin 1141-C, p. C1-C101.

1967a, Quaternary marine transgressions in Alaska, in Hopkins, D.M., ed., The Bering land bridge: Stanford, Calif., Stanford University Press, p. 47-90.

1967b, The Cenozoic history of Beringia-A synthesis, in Hopkins, D.M., ed., The Bering land bridge: Stanford, Calif., Stanford University Press, p. 451-484.

1968, Placer prospects in northern Bering Sea [abs.]: Mining Engineering, v. 20, p. 92.

1972, The paleogeography and climatic history of Beringia during late Cenozoic time: International Journal of Arctic and Nordic Studies, no. 12, p. 121-150.

-1973 , Sea level history in Beringia during the past 250,000 years: Quaternary Research, v. 3, p. 520-540.

1982, Aspects of the paleogeography of Beringia during the late Pleistocene, in Hopkins, D.M., ed., Paleoecology of Beringia: New York, Academic Press, p. 3-28.

Hopkins, D.M., Brigham-Grette, J., and Kaufman, D.S., 1989, Age and significance of the Anaktuvuk/Nome River glaciation, north-central Beringia: Abstracts of the 18th annual Arctic Workshop, Lethbridge, Canada, April 13-15, 1989, p. 27.

Hopkins, D.M., MacNeil, F.S., and Leopold, E.B., 1960, The coastal plain at Nome, Alaska-A type section for the Bering Strait region, in Chronology and climatology of the Quaternary: 21st International Geological Congress, Copenhagen, 1960, part 4, p. 46-57.
Hopkins, D.M., Matthews, J.V., Wolfe, J.A., and Silberman, M.L., 1971, A Pliocene flora and insect fauna from the Bering Strait region: Palaeogeography, Palaeoclimatology, Palaeoecology, v. 9, p. 211-231.

Hopkins, D.M., Nelson, C.N., Perry, R.B., and Alpha, Tau Rho, 1976, Physiographic subdivisions of the Chirikov Basin, northern Bering Sea: U.S. Geological Survey Professional Paper 759-B, p. B1-B7.

Hopkins, D.M., Rowland, R.W., and Patton, W.W., 1972, Middle Pleistocene mollusks from St. Lawrence Island and their significance for the paleo-oceanography of the Bering Sea: Quaternary Research, v. 2, p. 119-134.

Hummel, C.H., 1962, Preliminary geologic map of the Nome C-1 quadrangle, Seward Peninsula, Alaska: U.S. Geological Survey Mineral Investigations Field Studies Map MF-247, scale 1:63,360.

Huston, M.M., Brigham-Grette, J., and Hopkins, D.M., 1989, Marine and glacial stratigraphy and geochronology of a middle Pleistocene glacio-tectonized moraine complex, Kotzebue Sound, Alaska: Abstracts of the 18th annual Arctic Workshop, Lethbridge, Canada, April 13-15, 1989, p. 28-30.

Jenkins, R.L., and Lense, A.H., 1967, Marine heavy metals project offshore Nome, Alaska July-August, 1967: Bureau of Mines Technical Progress Report, $11 \mathrm{p}$.

Johnson, J.L., and Holmes, M.L., 1980, Surface and subsurface faulting in Norton Sound and Chirikov Basin, Alaska, in Larsen, M.C., Nelson, C.H., and Thor, D.R., eds., Geological, geochemical, and geotechnical observations on the Bering shelf, Alaska: U.S. Geological Survey OpenFile Report 80- 979, 25 p.

Jones, H.A., and Davies, P.J., 1979, Preliminary studies of offshore placer deposits, eastern Australia: Marine Geology, v. 30 , p. $243-268$

Kaufman, D.S., and Calkin, P.E., 1988, Morphometric analysis of Pleistocene glacial deposits in the Kigluaik Mountains, northwestern Alaska: Arctic and Alpine Research, v. 20, p. 273-284.

Kaufman, D.S., and Hopkins, D.M., 1986, Glacial history of the Seward Peninsula, in Hamilton, T.D., Reed, K.M., and Thorson, R.M., eds., Glaciation in Alaska-The geologic record: Anchorage, Alaska Geological Society, p. 51-78.

Kaufman, D.S., Hopkins, D.M., and Calkin, P.E., 1988, Glacial geologic history of the Salmon Lake area, Seward Peninsula, in Galloway, J.P., and Hamilton T.D., eds., Geologic studies in Alaska by the U.S. Geological Survey during 1987: U.S. Geological Survey Circular 1016, p. 91-94.

Khoreva, I.M., 1974, Stratigraphy and foraminifera of the marine Quaternary deposits of the west shore of the Bering Sea: Akademy Nauk USSR Geologic Institute, v. 225, $152 \mathrm{p}$.

Knebel, H.J., Creager, J.S., and Echols, R.J., 1974, Holocene sedimentary framework, east-central Bering Sea continental shelf, in Herman, Y., ed., Marine geology and oceanography of the Arctic seas: New York, SpringerVerlag, p. 157-172.

Komar, P.D., and Wang, C., 1984, Processes of selective grain transport and the formation of placers on beaches: Journal of Geology, v. 92, p. 637-655.

Larsen, M.C., Nelson, C.H., and Thor, D.R., 1981, Sedimentary 
processes and potential geologic hazards on the sea floor of the northern Bering Sea, in Hood, D.W., and Celder, J.A., eds., The eastern Bering Sea shelf-Oceanography and resources, volume 1: National Oceanographic and Atmospheric Administration, p. 247-262.

Lu, F.C., Heiner, L.E., and Harris, D.P., 1968, Known and potential mineral resources, Seward Peninsula, Alaska: Fairbanks, University of Alaska, Mineral Industry Research Laboratory Report No. 18, 107 p.

MacNeil, F.S., Mertie, J.B., and Pilsbry, H.A., 1943, Marine invertebrate faunas of the buried beaches near Nome, Alaska: Journal of Paleontology, v. 17, p. 69-96.

McCulloch, D.S., 1967, Quaternary geology of the Alaskan shore of Chukchi Sea, in Hopkins, D.M., ed., The Bering land bridge: Stanford, Calif., Stanford University Press, p. $91-120$.

McManus, D.A., and Creager, J.S., 1984, Sea level data for parts of the Bering-Chukchi shelves of Beringia from 19,000 to 10,00014 C years B.P.: Quaternary Research, v. 21, p. $317-325$.

McManus, D.A., Venkatarathnam, K., Hopkins, D.M., and Nelson, C.H., 1974, Yukon River sediment on the northernmost Bering Sea Shelf: Journal of Sedimentary Petrology, v. 44, p. 1052-1060.

McManus, D.A., Venkatarathnam, K., Hopkins, D.M., and Nelson, C.H., 1977, Distribution of bottom sediments on the continental shelf, northern Bering Sea: U.S. Geological Survey Professional Paper 759-C, p. C1-C31.

Miller, G.H., 1985, Aminostratigraphy of Baffin Island shellbearing deposits, in Andrews, J.T., ed., Quaternary environments-Baffin Island, Baffin Bay and West Greenland: Londoon, George Allen and Unwin, p. 394-427.

Moffitt, F.H., 1913, Geology of the Nome and Grand Central quadrangles, Alaska: U.S. Geological Survey Bulletin $533,140 \mathrm{p}$.

Nelson, C.H., 1971, Northern Bering Sea, a model for depositional history of Arctic shelf placers--Ecological impact of placer development: First International Conference on Port and Ocean Engineering under Arctic Conditions, v. 1, p. 246-254.

1978, Faulting, sediment instability, erosion, and depositional hazards of the Norton Basin sea floor, in Environmental assessment of the Alaskan Continental Shelf, annual reports of the principal investigators for the year ending March, 1978, Volume XII, Hazards, p. 187-307. 1982, Late Pleistocene-Holocene transgressive sedimentation in deltaic and non-deltaic areas of northeastern Bering epicontinental shelf: Geologie en Mijnbouw, v. 61, p. 5-18.

Nelson, C.H., and Creager, J.S., 1977, Displacement of Yukonderived sediment from Bering Sea to Chukchi Sea during Holocene time: Geology, v. 5, p. 141-146.

Nelson, C.H., Dupre, W., Field, M., and Howard, J.D., 1982, Variation in sand body types on the eastern Bering Sea epicontinental shelf: Geologie en Mijnbouw, v. 61, p. 37-48.

Nelson, C.H., and Hopkins, D.M., 1972, Sedimentary processes and distribution of particulate gold in the northern Bering Sea: U.S. Geological Survey Professional Paper $689,27 \mathrm{p}$.
Nelson, C.H., and Nio, S.D., 1982, The northeastern Bering shelf-New perspective of epicontinental shelf processes and depositional products, an introduction: Geologie en Mijnbouw, v. 61, p. 2-4.

Nelson, C.H., Pierce, D.E., Leong, K.W., and Wang, F.H., 1972, Mercury distribution in ancient and modern sediment of northeastern Bering Sea: U.S. Geological Survey OpenFile Report 72-533, 29 p.

Petrov, O.M., 1967, Paleogeography of Chukotka during Late Neogene and Quaternary time, in Hopkins, D.M., ed., The Bering land bridge: Stanford, Calif., Stanford University Press, p. 144-171.

Reid, I., and Frostick, L.E., 1985, Role of settling, entrainment and dispersive equivalence and of interstice trapping in placer formation: Journal of Geological Society of London, v. 142, p. 739-746.

Sainsbury, C.L., 1967a, Quaternary geology of western Seward Peninsula, Alaska, in Hopkins, D.M., ed., The Bering land bridge: Stanford, Calif., Stanford University Press, p.121-143.

1967b, Upper Pleistocene features in the Bering Strait area, in Geological Survey research 1967: U.S. Geological Survey Professional Paper 575-D, p. D203-D213.

Sainsbury, C.L., Hummel, C.L., and Hudson, Travis, 1972, Reconnaissance geologic map of the Nome quadrangle, Seward Peninsula, Alaska: U.S. Geological Survey Open-File Report 72-326, 28 p.

Scholl, D.W., and Hopkins, D.M., 1969, Newly discovered Cenozoic basins, Bering Sea shelf, Alaska: American Association of Petroleum Geologists Bulletin, v. 53, p. 2067-2078.

Shackleton, H.J., and Opdyke, N.D., 1976, Oxygen-isotope and paleomagnetic stratigraphy of Pacific core V28-239-Late Pliocene to latest Pleistocene: Geological Society of America Memoir 145, p. 449-464.

Sharma, G.D., 1974, Geological oceanography near Nome, in Hood, D.W., ed., Environmental study of the marine environment near Nome, Alaska: Fairbanks, University of Alaska, Institute of Marine Science Report 74-3, p. 111-141.

Sheth, M., 1971, A heavy mineral study of Pleistocene and Holocene sediments near Nome, Alaska: U.S. Geological Survey Open-File Report 71-464, 83 p.

Silberman, M.L., 1969, Preliminary report on electron microscopic examination of surface texture of quartz sand grains from the Bering shelf: U.S. Geological Survey Professional Paper 650-C, p. C33-C37.

Sutherland, D.G., 1985, Geomorphological controls on the distribution of placer deposits: Journal of Geological Society of London, v. 142, p. 727-737.

1987, Placer deposits of the nearshore and coastal zones-The role of littoral processes and sea-level changes in their formation, in Devoy, R.J.N., ed., Sea surface studies: New York, Croom Helm, p. 569-588.

Tagg, A.R., and Greene, H.G., 1973, High-resolution seismic survey of an offshore area near Nome, Alaska: U.S. Geological Survey Professional Paper 759-A, p. A1-A23.

Thor, D.R., and Nelson, C.H., 1980, A summary of interacting, surficial geologic processes and potential geological hazards in the Norton Basin, northern Bering Sea: Offshore Technology Conference Paper No. 3400, p. 377-381. 
Till, A.B., Dumoulin, J.A., Gamble, B.M., Kaufman, D.S., and Carroll, P.I., 1986, Preliminary geologic map and fossil data from Solomon, Bendeleben, and southern Kotzebue quadrangles, Alaska: U.S. Geological Survey Open-File Report 86-276.

Tuck, Ralph, 1968, Origin of the bedrock values of placer deposits: Economic Geology, v. 63, no. 2, p. 191-193.

Turner, R.F., ed., 1986, Geologic report for the Norton Basin Planning Area, Bering Sea, Alaska: Minerals Management Service Outer Continental Shelf Report 86-0033, $179 \mathrm{p}$.

U.S. Bureau of Mines, Marine Minerals Technology Center, 1967, Sample drilling sea floor heavy metals placer deposits off Alaska's Nome beach-The Bureau of Mines 1967 offshore campaign: Torbin, Calif., Final draft report, 207 p., 21 plates.

U.S. Minerals Management Service, 1988, Proposed Norton Sound lease sale: Draft Environmental Impact Statement: Anchorage, Alaska, Outer Continental Shelf Report 88-0082.

U.S. Office of Technology Assessment, 1987, Marine minerals-Exploring our new ocean frontier: Washington, D.C., OTA-O-342, p. 199-204.

Venkatarathnam, K., 1971, Clastic sediments on the continental shelf of the northern Bering Sea: Seattle, University of Seattle, Department of Oceanography Special Report 41, p. $40-61$.

Wehmiller, J.F., 1982, A review of amino acid racemization studies in Quaternary mollusks-Stratigraphic and chronologic applications in coastal and interglacial sites, Pacific and Atlantic coasts, United States, United Kingdom, Baffin Island, and Tropical Islands: Quaternary Science Reviews, v. 1, p. 83-120.

Yeend, W., 1984, Gold in Tertiary(?) rocks, Circle quadrangle, Alaska, in Coonard, W.L., ed., The United States Geological Survey in Alaska-Accomplishments during 1981: U.S. Geological Survey Circular 868, p. 65-66.

Yeend, W., Kaufman, D.S., and Till, A.B., 1988, Map showing placer gold in the Solomon, Bendeleben, and southern part of the Kotzebue quadrangles, western Alaska: U.S. Geological Survey Miscellaneous Field Studies Map MF-1838-C, scale 1:250,000.

\section{Reviewers:}

Gifford Miller

Warren Yeend 


\title{
Nature of the Basal Contact of the Tozitna Terrane along the Dalton Highway, Northeast Tanana Quadrangle, Alaska
}

\author{
By Thomas E. Moore and John M. Murphy
}

\begin{abstract}
Geologic mapping in the Fort Hamlin Hills in central Alaska shows that the basal contact of the Tozitna terrane is exposed in roadcuts between mileposts 65 and 72 of the Dalton Highway. Although elsewhere poorly exposed, many workers have proposed that this contact is a low-angle fault of regional significance. Our mapping shows that a structural stratigraphy is present along the contact and consists of, from structural base to top, (1) undeformed to strongly folded sedimentary rocks associated with the Ruby terrane; (2) flaggy phyllite with sedimentary structures transposed by foliation; (3) tectonic melange consisting of volcanogenic rocks, quartzose sandstone, and chert-pebble conglomerate in a scaly argillite matrix, and (4) fault slivers of volcanic rocks, diabase, bedded chert, argillite, and lithic sandstone of the Tozitna terrane. We interpret the structural stratigraphy and other field data as evidence that, at least at this locality, the basal contact of the Tozitna terrane is a shallow, southward-dipping zone of distributed shear as much as 2 $\mathrm{km}$ thick.
\end{abstract}

\section{INTRODUCTION}

The Tozitna terrane (Jones and others, 1987) consists of a structurally complex assemblage of mafic igneous rocks of probable oceanic affinity with lesser amounts of tuff, chert, argillite, graywacke, and limestone (Jones and others, 1986, 1987; Patton and Box, in press). This terrane forms part of a northeast-trending belt along the east flank of the Ruby geanticline in central Alaska and extends into the northeastern end of the Brooks Range (fig. 1). Together with the Angayucham and Innoko terranes (Jones and others, 1987), Jones and others (1986) and Patton and Box (in press) proposed that the Tozitna terrane represents parts of enormous thrust sheets of mafic and ultramafic rocks emplaced during Early Cretaceous time onto the regionally metamorphosed rocks of the continental Arctic Alaska and Ruby terranes (Jones and others, 1987). Although tectonic contacts are exposed at the base of the Angayucham terrane in the Brooks Range (Nelson and Nelson, 1982; Dillon and others, 1986; Ellersieck and others, 1984), the basal contact of the Tozitna terrane on the
Ruby terrane is mostly concealed or poorly exposed. During the 1988 field season of the Trans-Alaska Crustal Transect (TACT) geologic studies project, we examined and mapped this contact in several places where it is reasonably well exposed in cuts along the Dalton Highway and nearby Trans-Alaska pipeline, about $15 \mathrm{~km}$ northwest of the Yukon Crossing (figs. 1, 2). Our observations indicate that the base of the Tozitna terrane is a gently dipping tectonized zone at least $2 \mathrm{~km}$ thick and consists of a vertical succession of mappable structural units. This paper describes the structural stratigraphy of this tectonized zone and our preliminary ideas of its origin.

\section{GEOLOGIC SETTING}

Regional mapping (Patton and Miller, 1973; Brosgé and others, 1973) has shown that the preCretaceous rocks of central Alaska north of the Yukon River consist of four primary lithologic belts. Units composed of quartz-mica schist with rare marble, quartzite, and orthogneiss form the core of the northeasttrending Ruby geanticline. Flanking these metamorphic rocks are parallel belts of phyllite and metagraywacke, mafic volcanogenic rocks, and gabbroic and ultramafic rocks. The sedimentary protolith of the phyllite and metagraywacke belt consists of quartz and chert-rich detritus of Devonian age (Murphy and Patton, 1988) and was originally included with the quartz-rich metamorphic rocks in the Ruby terrane by Jones and others (1986, 1987). On the other hand, the upper Paleozoic and lower Mesozoic volcanic, gabbroic, and ultramafic rocks were assigned to the Tozitna and Angayucham terranes. The Tozitna and Angayucham terranes are distinguished on the basis of varying proportions of key lithologies and their respective structural positions on opposite sides of the Ruby geanticline. Recently, Patton and Box (in press) have revised this nomenclature and refer to the phyllitemetagraywacke, volcanogenic, and gabbroic and ultramafic belts as the Slate Creek, Narvak, and Kanuti thrust panels, respectively, of their composite AngayuchamTozitna terrane, whereas the Ruby terrane is restricted to 
the quartz-mica schists in the core of the Ruby geanticline. This scheme emphasizes the close structural association of the three belts flanking the Ruby geanticline throughout central Alaska. It also notes that both the Tozitna and Angayucham terranes consist of similar successions of flat- to moderate-dipping thrust sheets which are arranged in a consistent stacking order (in ascending order, Slate Creek, Narvak, and Kanuti thrust panels). Although we use the nomenclatural system of Patton and Box (in press), we believe that the striking contrast between the quartzose composition and probable continental provenance of strata in the Slate Creek thrust panel and the dominantly mafic igneous rocks of probable oceanic affinity in the Narvak thrust panel

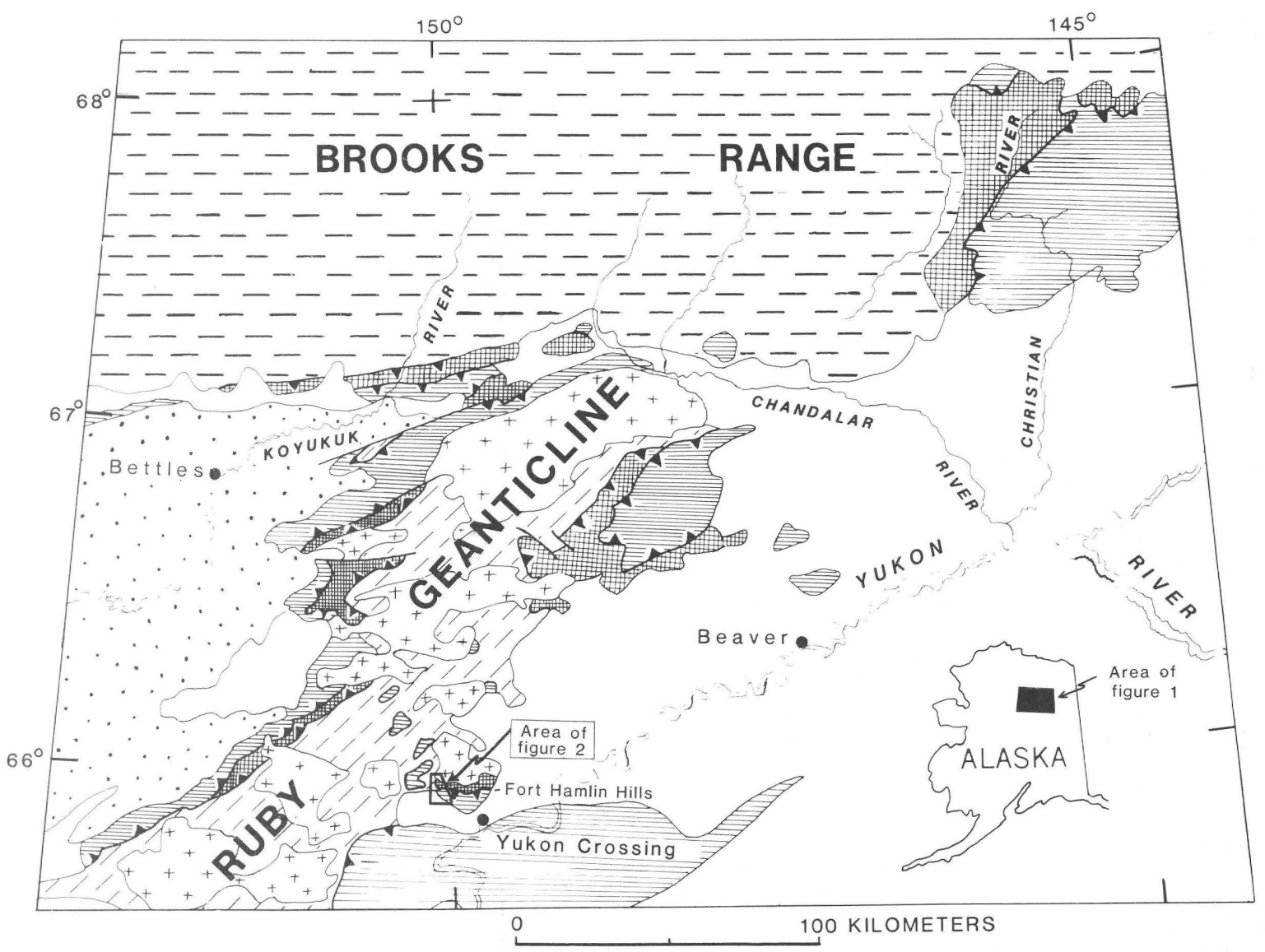

EXPLANATION

Overlap Assemblages

Volcanic and unconsolidated deposits (Cenozoic)

$t_{+}^{+}$Granitic rocks (Cretaceous)

$\therefore \because$ Terrigenous sedimentary rocks (Cretaceous)

\section{Contact--Depositional or intrusive}

\section{- High-angle fault}

\section{$\checkmark$ Thrust fault--Sawteeth on upper plate}

\section{Terranes}

Angayucham-Tozitna composite terrane Kanuti and Narvak thrust panels (Jurassic to Devonian)

Slate Creek thrust panel (Devonian)

- - A Arctic Alaska terrane (Paleozoic and Precambrian?)

$\measuredangle, /$ Ruby terrane (Paleozoic and Precambrian?)

Figure 1. Simplified geologic map showing major tectonostratigraphic units in central Alaska and study area (fig. 2). Modified from Murphy and Patton (1988). 


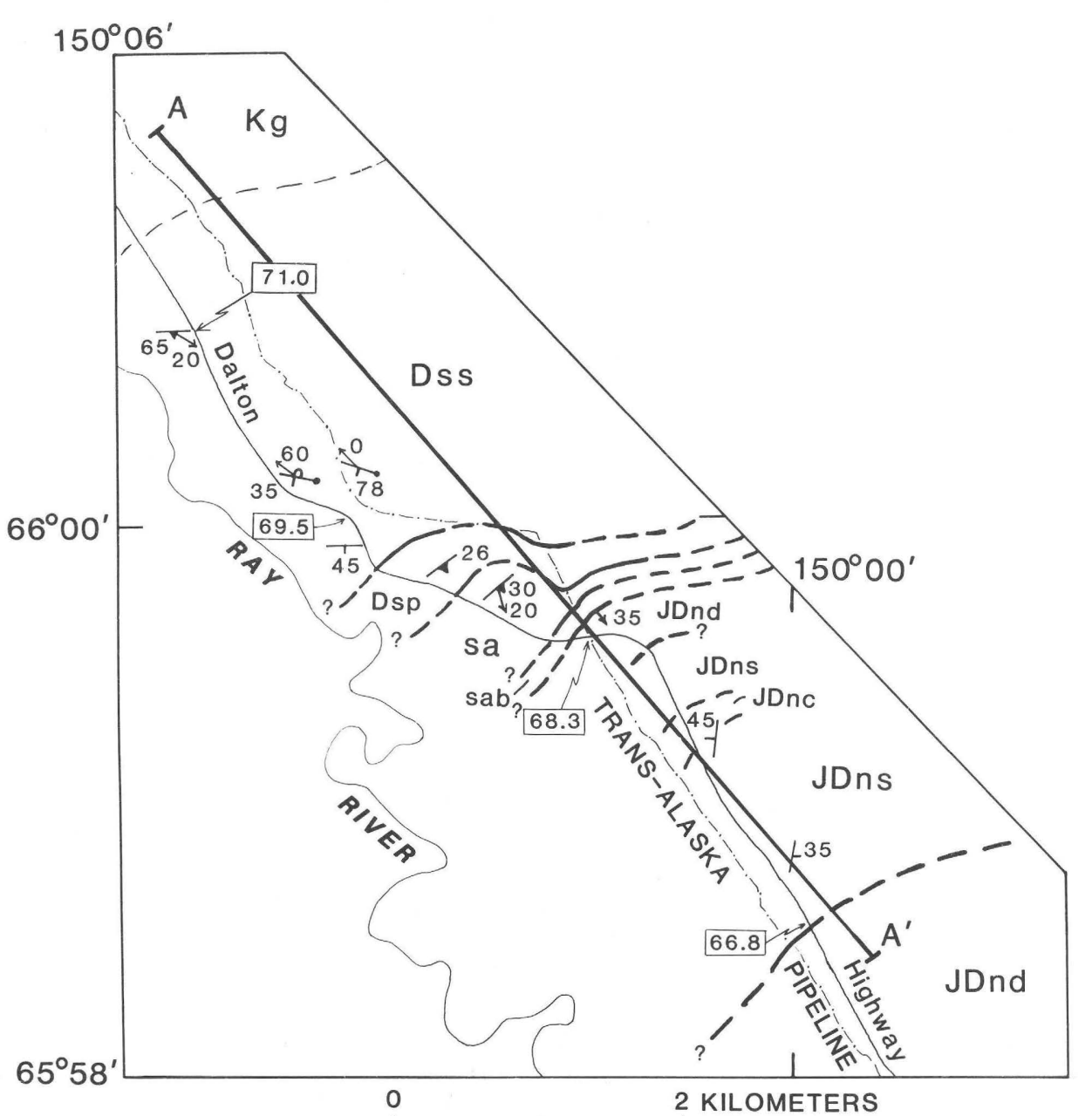

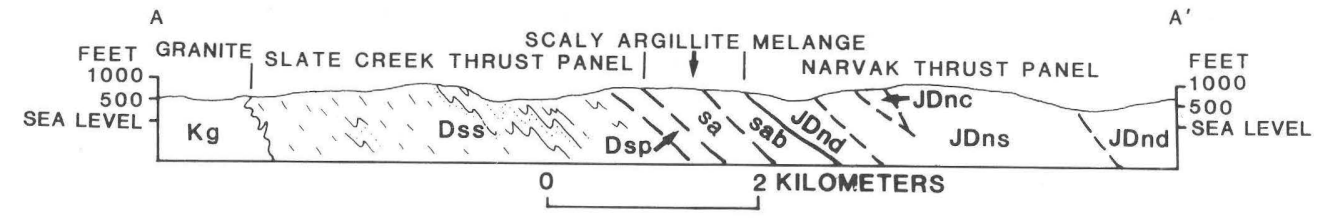

$\mathrm{Kg}$

JDnd

JDns

JDnc

Dsp

Dss

sab

sa

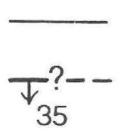

$\varpi_{35}^{?-}$

\section{EXPLANATION}

Granite (Cretaceous)--Medium grained, porphyritic

Narvak thrust panel (Jurassic to Devonian) Diabase, volcanic rocks, rare argillite, and chert

Lithic sandstone

Chert

Slate Creek thrust panel (Devonian)

Phyllite--Planar foliated, flaggy

Quartzose turbidites

\section{Scaly argillite melange}

Scaly argillite--Black, commonly with outsized blocks

Scaly argillite and pencil-cleaved scaly argillite

Contact--Approximately located

Fault--Showing dip. Dashed where approximately located, queried where uncertain

Strike and dip of beds

Inclined--Ball indicates top of beds known from sedimentary structures

$L_{\text {. }}^{35}$ Overturned--Top of beds known

${ }^{0}{ }^{30}$ Strike and dip of foliation and plunge of lineation

60 Minor fold axis showing plunge--Combined with planar symbols

68.3 Dalton Highway milepost

Figure 2. Geologic map and cross section of area between mile 65 and 72 of Dalton Highway, about 15 km northwest of Yukon Crossing (fig. 1). 
indicates that this contact is one of the most fundamental tectonostratigraphic boundaries in central Alaska.

\section{GEOLOGY OF THE FORT HAMLIN HILLS}

Three important east-trending and south-dipping units can be distinguished locally in the Fort Hamlin Hills, about $15 \mathrm{~km}$ northwest of the Yukon Crossing (figs. 1, 2). These units are best exposed in roadcuts between mileposts 65 and 72 of the Dalton Highway. The southernmost and structurally highest unit consists of diabasic intrusive and mafic volcanic rocks assigned to the Narvak thrust panel, whereas the northernmost and structurally lowest unit consists of thin-bedded sandstone, argillite, and phyllite assigned to the Slate Creek thrust panel. The intervening, lithologically mixed and structurally complex unit consists of broken formation, imbricate fault slices, and tectonic melange. These three units extend eastward for a strike distance of at least 15 $\mathrm{km}$.

A granite pluton intrudes the Slate Creek thrust panel where exposed along Dalton Highway. This pluton extends eastward along the northern flank of the Fort Hamlin Hills where it intrudes schist of the Ruby terrane (figs. 1, 2). On the eastern flank of the Fort Hamlin Hills, we observed a thin zone of multiply deformed schist of the Ruby terrrane along the southern margin of the pluton. Although we could only approximately locate the contact of these schists with the metasedimentary rocks of the Slate Creek unit in this area, these regional relationships indicate that the rocks of the Ruby terrane lie to the north, and beneath the Slate Creek thrust panel. Neither the pluton nor its weakly developed biotite and andalusite contact-metamorphic aureole were observed to crosscut the tectonized unit between the Narvak and Slate Creek thrust panels. Although undated, the pluton is lithologically similar to the widespread granitic batholiths of the Ruby geanticline dated by K-Ar and U-Pb methods at 104 to $112 \mathrm{Ma}$ (Patton and others, 1987). Regionally, some of these batholiths intrude across the Ruby-Tozitna terrane boundary, suggesting that the pluton in the Fort Hamlin Hills postdates the deformational structures contained in the Slate Creek thrust panel (Patton and Miller, 1973; S.E. Box, U.S. Geological Survey, written commun., 1988).

\section{STRUCTURAL STRATIGRAPHY ALONG DALTON HIGHWAY}

In roadcuts between mileposts 65 and 72 of the Dalton Highway at the eastern end of the Fort Hamlin Hills, the three map units are characterized by a succession of deformational structures as well as lithological changes. From base to top, this structural stratigraphy consists of (1) sedimentary and metasedimentary rocks of the Slate Creek thrust panel which display increasingly smaller scale structures upward, (2) a mixed zone consisting of scaly argillite and melange, and (3) apparently coherent mafic volcanogenic rocks and lithic sandstone of the Narvak thrust panel (fig. 3).

Slate Creek thrust panel.-In the study area, the Slate Creek thrust panel consists of mildly foliated metasedimentary rocks that largely retain their sedimentary character. Dominant lithologies in the unit are argillite, graphitic phyllite, and thin-bedded, fine-grained and very fine grained sandstone (quartz and chert arenite). Sandstone-to-shale ratios in the unit are less than 1 to 10 , and most sandstone beds are less than $5 \mathrm{~cm}$ thick, although some are as thick as $20 \mathrm{~cm}$. The sandstone beds are commonly graded and locally display flute casts, groove marks, parallel lamination, convolute lamination, bioturbation, current ripple markings, ball-and-pillow structures, and intraformational folding. Bouma Tde sequences (Walker, 1984) characterize the unit, but rare

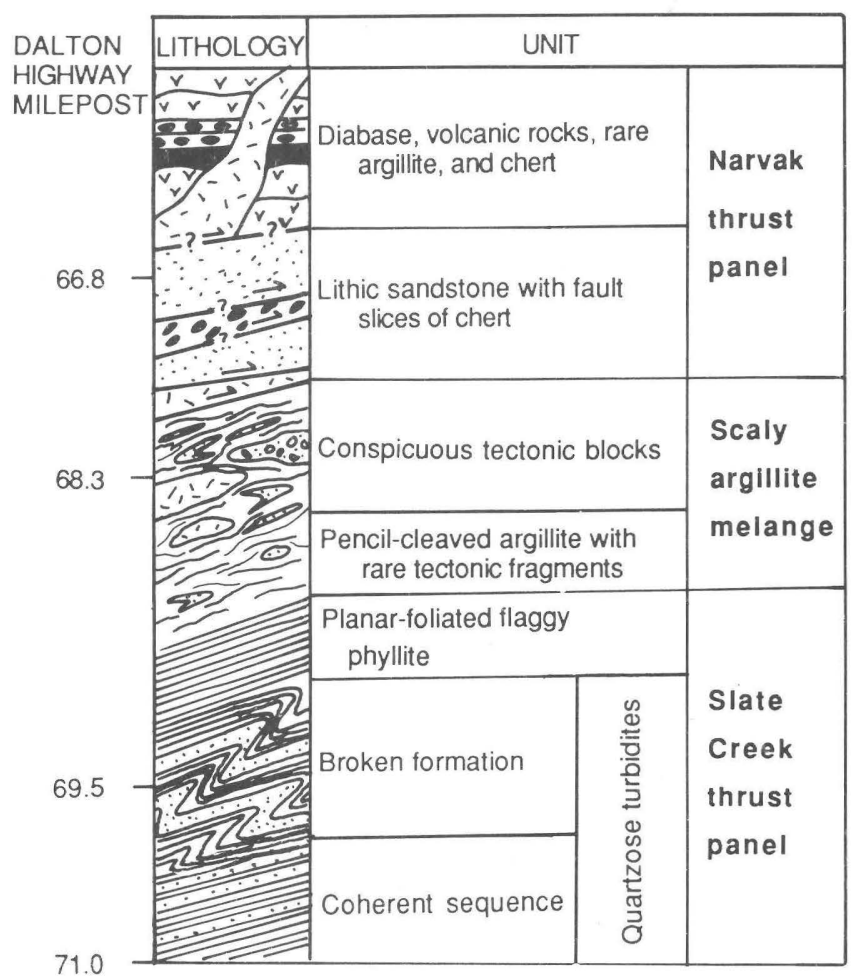

\section{EXPLANATION}

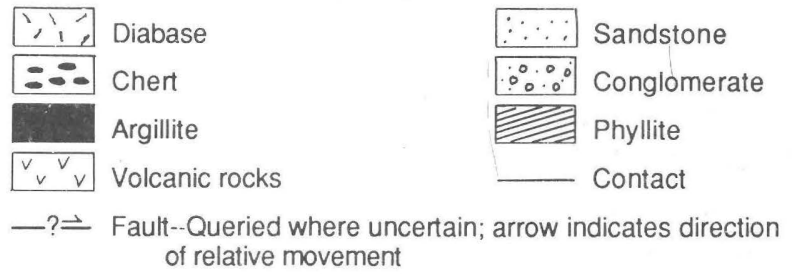

Figure 3. Generalized structural stratigraphic section between mile 66 and 71 of Dalton Highway (fig. 2). Thicknesses are approximate. 
Ta-d sequences, coupled with the other sedimentary structures, indicate deposition of the unit by turbidity currents. Bedding in the unit appears to be nonchannelized and laterally continuous, suggesting deposition in a basin-plain or interchannel environment on a submarine fan or a prodelta environment. In most places, the unit exhibits the lower greenschist facies metamorphic assemblage: quartz + albite + white mica + chlorite + rutile + pyrite (S.E. Box, U.S. Geological Survey, written commun., 1984). Relict textures and minerals indicate that the sedimentary protolith consisted largely of quartz grains with abundant muscovite and possibly recrystallized chert grains.

Along the Dalton Highway, the Slate Creek thrust panel has a structural thickness in excess of $3 \mathrm{~km}$ and displays an upward variation in structural characteristics. The structurally lowest unit (figs. 2, 3, roadcut at mile 71.0 ) of the thrust panel is generally coherent with a slaty cleavage parallel to bedding, although local changes of facing direction indicate the presence of outcrop- to map-scale folds. The structurally overlying unit of the thrust panel (figs. 2, 3, roadcut at mile 69.5) is highly disrupted and consists of broken formation. Sedimentary bedding in this unit displays abundant tight to isoclinal, asymmetric folds with fold amplitudes commonly less than $100 \mathrm{~cm}$. The folds have an associated axial-planar cleavage marked by a finely streaked crenulation lineation that plunges gently to the southeast and parallel to fold axes. This unit grades upward into flaggy phyllite with planar foliation which forms the structurally highest part of the Slate Creek thrust panel. Sedimentary structures are absent in this zone and are completely transposed by a strongly developed schistosity. The absence of sandstone and siltstone, the metamorphic texture, and the presence of S-C fabrics suggest that the uppermost unit may be mylonitic.

Scaly argillite melange unit.-The transitional zone intervening between the Slate Creek and Narvak thrust panels (fig. 3) is a zone of mixed lithologies about $1 \mathrm{~km}$ thick. This unit is characterized by black scaly argillite and pencil-cleaved argillite which is in gradational contact with the flaggy phyllite below. Throughout the unit, the argillite matrix has an anastamosing cleavage that approximately parallels the long dimensions of the enclosed blocks and clasts. Locally, the scaly cleavage is strongly crenulated and is cut at high angle by a spaced cleavage. At the base of the unit, the scaly argillite contains rare boudins of quartzose sandstone as much as $20 \mathrm{~cm}$ in length, but sedimentary structures are otherwise absent in the unit. Structurally higher in the scaly argillite melange unit, boudins of sandstone are more common and are increasingly large. Near the top of the unit (figs. 2,3 , road and pipeline cuts at mile 68.3) the scaly argillite forms a matrix that encloses phacoidal blocks of quartzose sandstone, diabase, and stretched chert-pebble conglomerate that are as much as $50 \mathrm{~m}$ in length. Rare blocks of crossbedded quartzite were also observed in this unit near the crest of the Fort Hamlin Hills to the east. Some of the sandstone phacoids in the road and pipeline cuts are dismembered isoclinal fold hinges that float in the scaly argillite. The scaly argillite matrix in this area displays a streaky appearance probably as a result of extensive attenuation of sandstone laminae and contains rare, angular grains and pebble-sized fragments of diabase and quartzose sandstone. Petrographic examination of one sandstone block shows that it contains an incipient pressure solution cleavage, but the clastic texture and composition of the grains are otherwise identical to samples from the Slate Creek thrust panel (Sarah Roeske, University of Miami (Ohio), written commun., 1988).

Narvak thrust panel.--Rocks of the Narvak thrust panel along the Dalton Highway are deeply weathered and relatively poorly exposed, but can be divided into units composed principally of (1) lithic sandstone and (2) mafic volcanic and hypabyssal rocks. The lithic sandstone unit (fig. 3) appears to be a local, $2 \mathrm{~km}$-thick unit caught between the scaly argillite melange unit and the more widespread volcanogenic rock unit. The lithic sandstone unit consists largely of massive fine-grained sandstone and minor interbedded dark-gray phyllite. Sandstoneto-shale ratios in this unit are much greater than 1 , and bedding thicknesses are typically greater than $50 \mathrm{~cm}$. Rare graded bedding, Bouma Ta-d sequences, and internal erosional contacts suggest that the unit consists of facies B and C turbidites. Sandstone in the unit consists of roughly equal amounts of quartz, plagioclase, chert, and argillite fragments with a small but significant component of potassium feldspar. In one roadcut, a narrow zone of recrystallized chert occurs within the unit (fig. 2, unit JDnc), suggesting that the unit is either interbedded or structurally interleaved with bedded chert. The composition and turbiditic character of the lithic sandstone unit resemble those of the Slate Creek thrust panel, raising the possibility that the lithic sandstone unit is a fault sliver of sandstone from the Slate Creek thrust panel caught along the margin of the scaly argillite melange unit. However, we provisionally assign the lithic sandstone unit to the Narvak thrust panel because (1) these sandstones contain a significantly larger proportion of feldspar and argillite grains than those reported for the Slate Creek thrust panel by Murphy and Patton (1988), (2) they display greater bedding thicknesses and represent a different sedimentary facies than the Slate Creek sandstones, (3) they are associated with probable fault slivers of diabase and chert and occur in a position adjacent to the Narvak thrust panel, and (4) they are less completely metamorphosed than the sandstone of the Slate Creek thrust panel.

Although poorly exposed, exposures in a few roadcuts and quarries suggest that the volcanogenic rock unit composes a greater proportion of the Narvak thrust 
panel than the lithic sandstone unit. The volcanogenic unit consists of diabasic bodies with thick, local units of interstratified red and brown argillite, maroon radiolarian chert, and thin beds of plagioclase crystal tuff. It is unclear whether the diabasic rocks represent holocrystalline volcanic flows interstratified with the sedimentary rocks or hypabyssal units intrusive into the sedimentary rocks. In one place in the Fort Hamlin Hills, the diabasic rocks display well-developed columnar jointing. Similar rocks of the Narvak thrust panel exposed along the Yukon River west of Yukon Crossing (fig. 1) consist of pillowed volcanic rocks with interpillow limestone and chert and intercalated debris flows composed of mafic volcanic debris. These volcanic and sedimentary rocks are intruded by extensive units of microgabbro which regionally are the best exposed rocks in the Narvak thrust panel. Only features indicative of brittle deformation were observed to deform this unit, both along the Yukon River and the Dalton Highway.

\section{STRUCTURAL DATA}

Most published interpretations suggest that the mafic igneous rocks of the Narvak thrust panel of the Angayucham-Tozitna terrane were structurally emplaced onto the Ruby terrane (for example, Gemuts and others, 1983; Jones and others, 1986; Patton and Box, in press), but vary on the direction and amount of structural transport. Gemuts and others (1983) proposed that the rocks assigned to the Angayucham and Tozitna terranes by Jones and others (1987) were formed in parallel southwest-trending basins and were emplaced onto the Ruby terrane of Jones and others (1987) along southeast-vergent thrust faults. Patton and Box (in press) suggest that the composite Angayucham -Tozitna terrane was rooted in the Koyukuk basin and was emplaced southeastward over the entire Ruby terrane during Early Cretaceous time. Jones and others (1986), on the other hand, suggested that the mafic igneous rocks of the Angayucham and Tozitna terranes together form a continuous sheet which overrode the continental crystalline rocks of the Ruby, Yukon-Tanana, and Arctic-Alaska terranes from the south. Dover and Miyaoka (1985) and Miyaoka and Dover (1985) also suggested northwestward emplacement for the Rampart Group (Tozitna terrane) over the Ruby terrane based on preliminary fabric analysis of structures in rocks assigned to the Ruby terrane by Jones and others (1987), but, like Gemuts and others (1983), did not correlate the Angayucham and Tozitna terranes.

Our structural data from deformed rocks in the Slate Creek thrust panel and the scaly argillite melange unit along the Dalton Highway define two structural domains (fig. 4). Domain 1 consists of structures in rocks of the Slate Creek thrust panel displaying bedding and other sedimentary features. This domain includes both upright and overturned beds with attitudes that roughly parallel the axial planes of gently west-northwestwardplunging fold axes. A few observations of fold asymmetry of domain 1 folds suggest clockwise, southwest-overnortheast fold asymmetry. These data, together with the presence of beds overturned toward the north, suggest a north-northeast structural vergence for this structural domain. A weak crenulation cleavage is developed across the axial plane cleavage, but apparently is not associated with large-scale folds.

Structural domain 2 consists of structures in the flaggy phyllitic rocks at the top of the Slate Creek thrust panel and in the scaly argillite melange unit. In this domain, poles to foliation form a diffuse partial girdle that originates at an orientation similar to the average orientation of the poles to bedding and axial planes of domain 1 . In general, the foliations in domain 2 dip south and southeast and display crenulation and other lineations that plunge down-dip toward the southeast. The dispersion of foliation is about the axis of crenulation lineations, suggesting that this foliation resulted from larger scale folding accompanying the development of the crenulation cleavage. This dispersion may alternatively reflect the splaying and merging of matrix foliation around structural blocks.

\section{CONCLUSION}

Our field data suggest that the contact between the Slate Creek and Narvak thrust panels of the Angayucham-Tozitna terrane represents an important zone of tectonic dislocation. The presence of a structural stratigraphy in the tectonized zone, coupled with its $2-\mathrm{km}$ thickness, suggests that the contact is a zone of distributed shear. The finer grain size, metamorphic texture, complete transposition of sedimentary structures, and possible mylonitic character suggest that the major locus of displacement is represented by the flaggy phyllite unit at the top of the Slate Creek thrust panel. Our structural observations indicate that the amount of strain increases upward from the mostly undeformed rocks of the Slate Creek thrust panel (domain 1) into the flaggy phyllite unit at the top of the Slate Creek thrust panel and the structurally higher scaly argillite melange unit (domain 2). The presence of a structural contact between the Narvak and Slate Creek thrust panels over a distance of at least $15 \mathrm{~km}$ supports the hypothesis of Jones and others (1986) and Patton and Box (in press) that the Narvak represents a widespread allochthonous assemblage that was emplaced structurally onto the quartzose metasedimentary rocks of the Slate Creek thrust panel and the Ruby terrane, but can also be accommodated in the model of Gemuts and others (1983). Although we found some evidence for northeastward structural trans- 


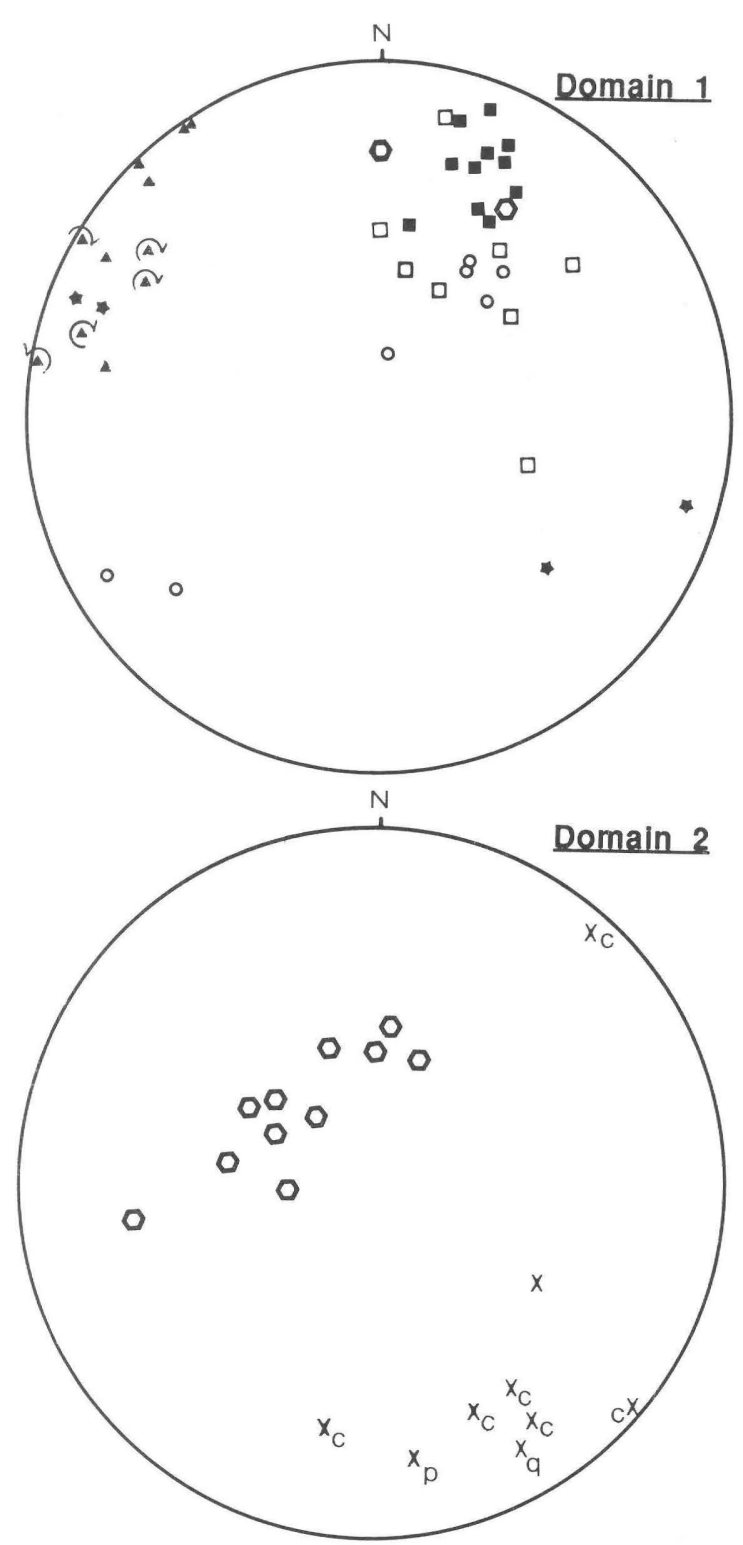

Domain 1

Bedding, upright

- Bedding, overturned

- Axial plane of fold

- Fold axis, rotation uncertain

(1. Fold axis, clockwise asymmetry viewed down dip

(A Fold axis, counterclockwise asymmetry viewed down dip

- Foliation

- Crenulation lineation, intersection of foliation and crenulation cleavage

\section{Domain 2}

- Foliation

$x$ Lineation; $c$, crenulation; $q$, quartz rod; $p$, pencil cleavage (intersection of foliation and cleavage) port, because of the reconnaisance nature of this paper, we are uncertain of the kinematic history in the tectonized zone. Because of this uncertainty and current inability to discern whether the structures represent pure or simple shear, we suggest that they may have been formed by either compressional or extensional structural processes. We note that the foliation and lineation data of domain 2 are similar to data reported by Dover and Miyaoka (1985) for phyllonite of the Ruby terrane and Slate Creek thrust panel about $75 \mathrm{~km}$ west of Yukon Crossing, which they interpret as evidence for updip convergence along a west-northwest-east-southeast axis. Both domains 1 and 2 display a late crenulation cleavage, but differ in that the crenulation cleavage of domain 2 is apparently associated with larger scale folds, whereas larger scale folds are not observed in domain 1. This difference in associated folds may indicate that the basal contact of the Narvak thrust panel was the site of two or more episodes or, alternatively, one complex episode of structural displacement.

\section{REFERENCES CITED}

Brosgé, W.P., Reiser, H.N., and Yeend, Warren, 1973, Reconnaissance geologic map of the Beaver quadrangle, Alaska: U.S. Geological Survey Miscellaneous Field Studies Map MF-525, scale 1:250,000.

Dillon, J.T., Brosgé, W.P., and Dutro, J.T., Jr., 1986, Generalized geologic map of the Wiseman quadrangle, Alaska: U.S. Geological Survey Open-File Report 86-219, scale $1: 250,000$.

Dover, J.H., and Miyaoka, R. T., 1985, Metamorphic rocks of the Ray Mountains-Preliminary structural analysis and regional tectonic implications, in Bartsch-Winkler, Susan, and Reed, K.M., eds., The United States Geological Survey in Alaska: Accomplishments during 1983: U.S. Geological Survey Circular 945, p. 36-38.

Ellersieck, Inyo, Curtis, S.M., Mayfield, C.F., and Tailleur, I.L., 1984, Reconnaissance geologic map of south-central Misheguk Mountain quadrangle: U.S. Geological Survey Miscellaneous Investigations Series Map I-1504, scale $1: 63,360$.

Gemuts, I., Puchner, C.C., and Steffel, C.I., 1983, Regional geology and tectonic history of western Alaska: Journal of the Alaska Geological Society, v. 3., p. 67-83.

Jones, D.L., Silberling, N.J., and Coney, P.J., 1986, Collision tectonics in the cordillera of western North America:

Figure 4. Lower hemisphere projections showing structural data collected between mile 68 and 71 of Dalton Highway. Domain 1 consists of structures found in deformed quartzose sedimentary rocks of lower part of Slate Creek thrust panel; domain 2 consists of structures observed in scaly argillite melange unit and the planar-foliated flaggy phyllite unit in upper part of Slate Creek thrust panel. 
Examples from Alaska, in Coward, M.P., and Ries, A.C., eds., Collision tectonics: Geological Society of London Special Publication 19, p. 367-387.

Jones, D.L., Silberling, N.J., Coney, P.J., and Plafker, George, 1987, Lithotectonic terrane map of Alaska: U.S. Geological Survey Miscellaneous Field Studies Map MF-1874A, scale $1: 2,500,000$.

Miyaoka, R.T., and Dover, J.H., 1985, Preliminary study of shear sense in mylonites, eastern Ray Mountains, Tanana quadrangle, in Bartsch-Winkler, Susan, ed., The United States Geologic Survey in Alaska: Accomplishments during 1984: U.S. Geological Survey Circular 967, p. 29-32.

Murphy, J.M., and Patton, W.W., Jr., 1988, Geologic setting and petrography of the phyllite and metagraywacke thrust panel, north-central Alaska, in Galloway, J.P., and Hamilton, T.D., eds., Geologic studies in Alaska by the U.S. Geological Survey during 1987: U.S. Geological Survey Circular 1016, p. 104-108.

Nelson, S.W., and Nelson, W.H., 1982, Geology of the Siniktanneyak Mountain ophiolite, Howard Pass quadrangle, Alaska: U.S. Geological Survey Miscellaneous Field
Studies Map MF-1441, scale 1:63,360.

Patton, W.W., Jr., and Box, S. E., in press, Tectonic setting of the Yukon-Koyukuk basin and its borderlands, western Alaska: Journal of Geophysical Research.

Patton, W.W., Jr., and Miller, T.P., 1973, Bedrock geologic map of Bettles and southern part of Wiseman quadrangles, Alaska: U.S. Geological Miscellaneous Geologic Investigations Map I-1071, scale 1:250,000.

Patton, W.W., Jr., Stern, T.W., Arth, J.G., and Carlson, Christine, 1987, New U-Pb ages from granite and granite gneiss in the Ruby geanticline and southern Brooks Range, Alaska: Journal of Geology, v. 95, p. 118-126.

Walker, R.G., 1984, Turbidites and associate coarse clastic deposits, in Walker, R.G., ed., Facies models: Geological Association of Canada, Geoscience Canada, reprint series 1, p.171-188.

\section{Reviewers:}

Steve Box

Warren Nokleberg 


\title{
Molybdenite in the Huron Creek Pluton, Western Livengood Quadrangle, Alaska
}

\author{
By Thomas D. Light and C. Dean Rinehart
}

\begin{abstract}
Six felsic plutons in the western Livengood quadrangle range in composition from monzonite to quartz monzonite. We infer a genetic relationship for the plutons, based on similar chemical compositions, alkalic affinities, modal plots, and ages. The Huron Creek, Wolverine Mountain, and East Wolverine quartz monzonitic plutons are more siliceous than the Sawtooth Mountain, Elephant Mountain, and West Wolverine plutons, which are predominantly monzonite. Samples from the Huron Creek and Wolverine plutons contained molybdenite, not previously reported from this area. The poorly exposed Huron Creek pluton contains molybdenite as discrete crystals in small quartz stringer veins. Field evidence indicates that the Huron Creek pluton is a cupola of a larger intrusive body. The lack of widespread chemical alteration associated with the intrusion indicates that it was relatively dry and that hydrothermal circulation was not well developed. The geochemical data from reconnaissance streamsediment and heavy-mineral-concentrate samples, the molybdenum-bearing veinlets, and the high level of exposure for the Huron Creek pluton all suggest that a reasonable possibility exists for the occurrence of porphyry Cu-Mo or polymetallic vein deposits associated with the pluton or for skarn deposits in the adjacent Amy Creek(?) unit. This reconnaissance investigation suggests, however, that mineral deposits, if any, associated with the plutons of the western Livengood quadrangle are probably of limited extent.
\end{abstract}

\section{INTRODUCTION}

The U.S. Geological Survey conducted multidisciplinary reconnaissance studies in the Livengood 1:250,000-scale quadrangle, Alaska, from 1986 to 1988 , to define the mineral resource potential of the area as part of the Alaska Mineral Resource Assessment Program (AMRAP). The Livengood quadrangle lies between $65^{\circ}$ and $66^{\circ}$ north latitude and between $147^{\circ}$ and $150^{\circ}$ west longitude. Six monzonitic to quartz monzonitic plutons intrude the metamorphic terrane of the western Livengood quadrangle (fig. 1); they are the Elephant Mountain, Wolverine Mountain, West Wolverine, East Wolverine, Sawtooth Mountain, and Huron Creek plutons. In 1987 previously unreported occurrences of molybdenite were discovered in the Huron Creek and Wolverine Mountain plutons. This report focuses on the petrography of the Huron Creek pluton and on the character and style of the molybdenite occurrence.

\section{REGIONAL SETTING}

The Livengood quadrangle lies mostly within the Yukon-Tanana Upland (Wahrhaftig, 1965), primarily a metamorphic terrane of quartzitic, pelitic, calcareous, and volcaniclastic metasedimentary rocks with some metamorphosed mafic and felsic igneous plutons, all of which have been intruded by Mesozoic and Cenozoic granitic rocks and minor amounts of intermediate and mafic rocks (Chapman and others, 1971). The major faults in the area are strike-slip splays of the Tintina fault zone and thrust faults (F.R. Weber, U.S. Geological Survey, written commun., 1988).

\section{GRANITOID ROCKS IN THE WESTERN LIVENGOOD QUADRANGLE}

The six plutons in the western part of the Livengood quadrangle lie within an irregular area $30 \mathrm{~km}$ long and $10 \mathrm{~km}$ wide (fig. 1). Five of the six plutons form topographic highs: Elephant Mountain, Wolverine Mountain, Sawtooth Mountain, and two unnamed hills northwest and southeast of Wolverine Mountain. The plutons composing these last two unnamed hills are informally referred to as the West Wolverine and East Wolverine plutons, respectively. The sixth and smallest pluton, the Huron Creek pluton, is poorly exposed on the flank and rounded crest of a small ridge alongside the creek for which it is named, about $6 \mathrm{~km}(4 \mathrm{mi})$ north of Sawtooth Mountain. Each of the plutons is surrounded by a zone of strongly hornfelsed sedimentary rocks. All have modal compositions in the quartz monzonite to monzonite fields of Streckeisen (1973; fig. $2 A$, this report). Samples from the Elephant Mountain, Sawtooth Mountain, and West Wolverine plutons fall dominantly within or close to the monzonite field, whereas those 
from the Huron Creek, Wolverine, and East Wolverine plutons are all within the quartz monzonite field (fig. $2 B$.)

We believe a genetic relationship among the six granitic plutons of the western Livengood quadrangle is indicated by several lines of evidence: (1) a generally narrow range in chemical composition is shown by the entire group, exclusive of a mafic but minor phase of the Sawtooth Mountain pluton. (2) Strong alkalinity for

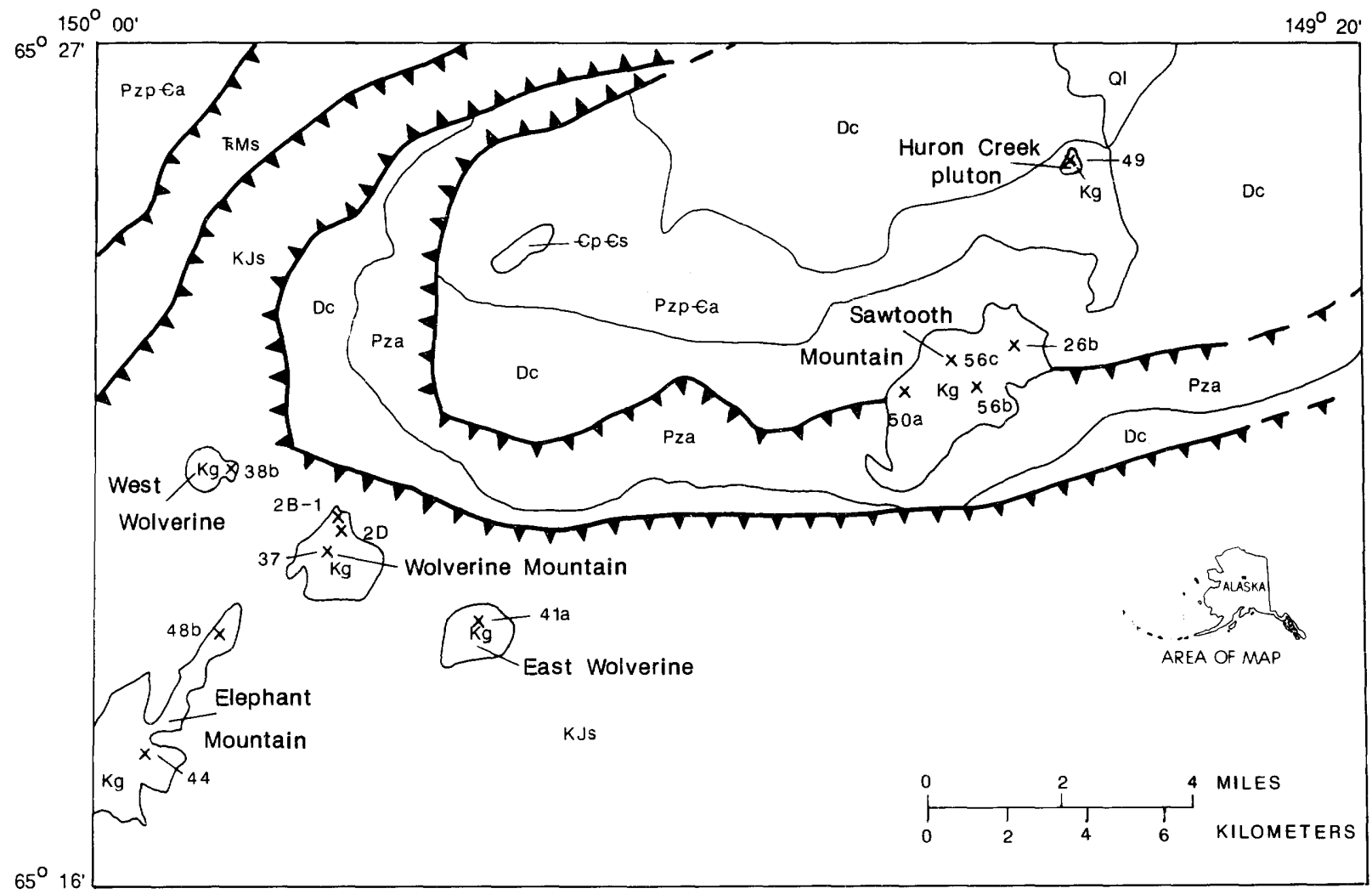

EXPLANATION

QI Loess and colluvium (Quaternary)

$\mathrm{Kg}$ Granitic rocks (Cretaceous)--Includes quartz monzonite and monzonite

KJs Shale, graywacke, and quartzite (Cretaceous and Jurassic)

TMs Sedimentary rocks (Triassic to Mississippian)--Includes argillite, chert, graywacke, shale, and limestone

Pza Argillite, chert, and mafic intrusive and extrusive rocks (upper? Paleozoic)

Dc Cascaden Ridge unit (Devonian)--Includes shale, graywacke, and conglomerate

Pzpea Amy Creek(?) unit (Paleozoic and Precambrian)--Includes dolomite, chert, greenstone, pelitic hornfels, and black slate

Epes Serpentinite, gabbro, diorite, and greenstone (Cambrian and Precambrian)

Contact

$\pi^{\top}$

Thrust fault--Dashed where inferred; sawteeth on upper plate

x 49 Sample locality--Numbers refer to table 1

Figure 1. Generalized geologic map of western part of Livengood 1:250,000-scale quadrangle showing location of granitoid plutons. Geology from F.R. Weber (U.S. Geological Survey, Fairbanks, Alaska, written commun., 1989). 
the entire suite is well expressed by the alkali-lime index of Peacock (1931; fig. 3) and is corroborated by several alternate techniques used to evaluate igneous rock chemistry (Irvine and Baragar, 1971; Le Bas and others, 1986; Peccerillo and Taylor, 1976). (3) The fairly compact field occupied by modal plots of samples from the entire suite (fig. 2) supports consanguinity. (4) Preliminary K-Ar biotite ages of $89 \pm 3 \mathrm{Ma}$ (Nora Shew, U.S. Geological Survey, Anchorage, Alaska, written commun., 1988; calculations using 1976 constants of Dalrymple, 1979) from the Elephant and Wolverine Mountain plutons are very similar to the $91 \pm 3 \mathrm{Ma}$ age (originally reported by Chapman and others, 1971 , as $88.8 \pm 3 \mathrm{Ma}$, based on formerly accepted constants) of the Sawtooth Mountain pluton, further suggesting a genetic link.

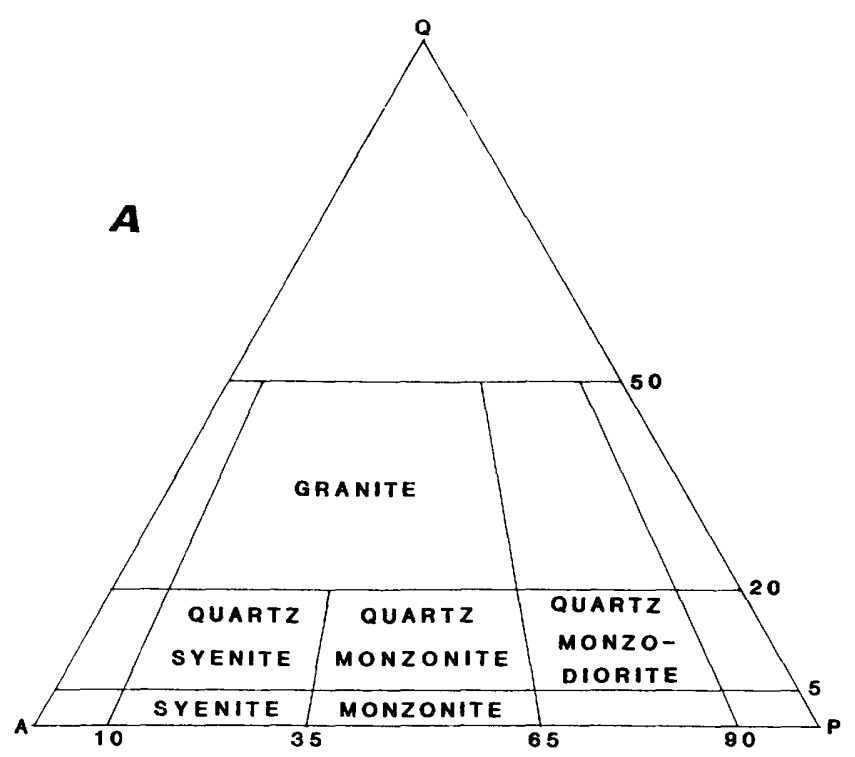

$\boldsymbol{B}$
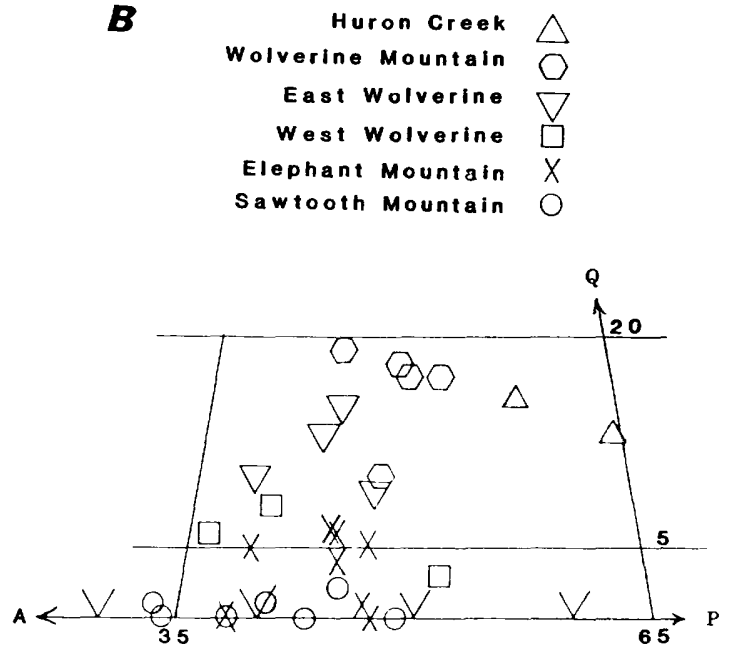

Figure 2. Modal plots of granitoid rocks, $A$, Modal classification from Streckeisen (1973). B, Plots of granitoid rocks from western part of Livengood 1:250,000-scale quadrangle.
Modal and chemical data for samples from the six plutons (table 1), along with the summary petrographic description of the composition, texture, and structure of samples from the six plutons (table 2), show that the Huron Creek pluton demonstrates greater chemical and petrographic affinity with the Wolverine and East Wolverine plutons than with the others, although the differences are not great. Perhaps the most unifying characteristics of each group, and those that show the greatest contrasts between them, are: femic oxides (oxides of $\mathrm{Fe}, \mathrm{Mg}$, and $\mathrm{Ca}$ ), $\mathrm{SiO}_{2}$, normative color index (CI), and differentiation index (DI). The latter two are related to the femic oxides and $\mathrm{SiO}_{2}$, respectively.

\section{HURON CREEK PLUTON}

The Huron Creek pluton consists of quartz monzonite that forms a small pluton emplaced in mainly northeast-trending contact-metamorphosed sedimentary rocks. The best exposure of the generally poorly exposed pluton is fresh unmineralized quartz monzonite rubble that caps a gentle ridgecrest (latitude $65^{\circ} 25^{\prime} 24^{\prime \prime} \mathrm{N}$.; longitude $149^{\circ} 28^{\prime} 38^{\prime \prime}$ W.) at an altitude of $800 \mathrm{~m}(2,650$ $\mathrm{ft}$ ) in the Livengood B5 1:63,360 quadrangle (fig. 4). In the same vicinity a roof remnant of metachert(?) occupies an area of several hundred square meters. Elsewhere, the adjacent country rock consists of dolomite, greenstone, pelitic hornfels, and black slate. The stratigraphic unit with which these metamorphic rocks correlate is uncertain, but is probably either the Amy Creek unit (Precambrian and Paleozoic) or the Livengood Dome Chert (Ordovician). Correlation with the Amy Creek unit is considered most likely (F.R. Weber, U.S. Geological Survey, Fairbanks, Alaska, written commun., 1989) and is the interpretation used on figure 1. Examination of the metamorphic rocks in rubbly exposure or in float reveals evidence of only minor local alteration, suggesting that the intrusion was relatively dry or that fluids emanating from or mobilized by the intrusion were channeled along restricted pathways.

Another exposure of the quartz monzonite was found on the ridgecrest about $780 \mathrm{~m}(2,500 \mathrm{ft})$ farther north with no outcrop in between. There, the rocks are locally bleached and altered and enclose fragments of fine-grained siliceous metasedimentary rocks. The only other outcrop seen, also on the ridgecrest, but $360 \mathrm{~m}$ $(1,200 \mathrm{ft})$ farther north, is a dikelike exposure of feldspar porphyry with a fine-grained matrix, suggesting a more hypabyssal origin. There, the microcrystalline matrix constitutes nearly 80 percent of the rock, and the Kfeldspar phenocrysts are smaller and less abundant than in rocks from the two outcrop areas to the south.

Modes of slabbed samples (fig. 2) from the main exposure on the ridgecrest and from similar rock composing the talus apron on the west show the rock to be a 
massive porphyritic quartz monzonite. Blocky euhedral $\mathrm{K}$-feldspar phenocrysts as much as $2 \mathrm{~cm}$ across but averaging less than $1 \mathrm{~cm}$ constitute 15-20 percent of the rock. The rest is divided equally between subangular to rounded broad plagioclase laths $2 \mathrm{~mm}$ long and a microcrystalline matrix. Quartz occurs as sparse rounded phenocrysts and also constitutes one-third of the fine-grained matrix. The remainder of the matrix is divided equally between mafic minerals and K-feldspar. Color index averages 13 .

In thin sections, milled off corners of phenocrysts and mosaic-textured matrix that locally resembles recrystallized mortar show that the quartz monzonite of the Huron Creek pluton has been mildly to moderately cataclastically deformed. K-feldspar phenocrysts are somewhat perthitic and sparsely poikilitic. Plagioclase is twinned and zoned oligoclase and andesine; much of the zoning is oscillatory. Broad, subequant, ragged crystals of biotite and hornblende are the principal mafic minerals and are about equal in abundance. The biotite has red-brown to black pleochroism with locally pleochroic haloes around monazite(?). A few subhedral allanite crystals, comparable in size to biotite and hornblende, are present. Alteration consists of moderate sericitization of plagioclase cores and minor to moderate replacement of biotite by chlorite. Accessory minerals, in addition to monazite, include apatite and opaque minerals, mainly magnetite raggedly exsolved in biotite.

Chemically, as well as petrographically, the Huron Creek pluton is a quartz monzonite and compares favorably with averages (adamellite) of both Nockolds (1954) and Le Maitre (1976) and by the chemical QAPF system of Streckeisen and Le Maitre (1979). Analyses for both major elements (table 1) and minor elements (not shown here) do not indicate any anomalously high concentrations of alteration- or ore-related minerals. The pluton is peraluminous, containing corundum in the norm, and contrasts with its nearest neighbor, the Sawtooth Mountain pluton, which is a fairly coarse grained, highly varied quartz-poor and quartz-free monzonite.

Based on the nature of the ridgecrest exposures, relative abundance of roof remnants, and the hypabyssal character of the rock itself, the Huron Creek pluton appears to be the exposed top of a larger pluton. Present exposures may represent cupolas, and as such, the rocks may differ somewhat in composition from a parent body

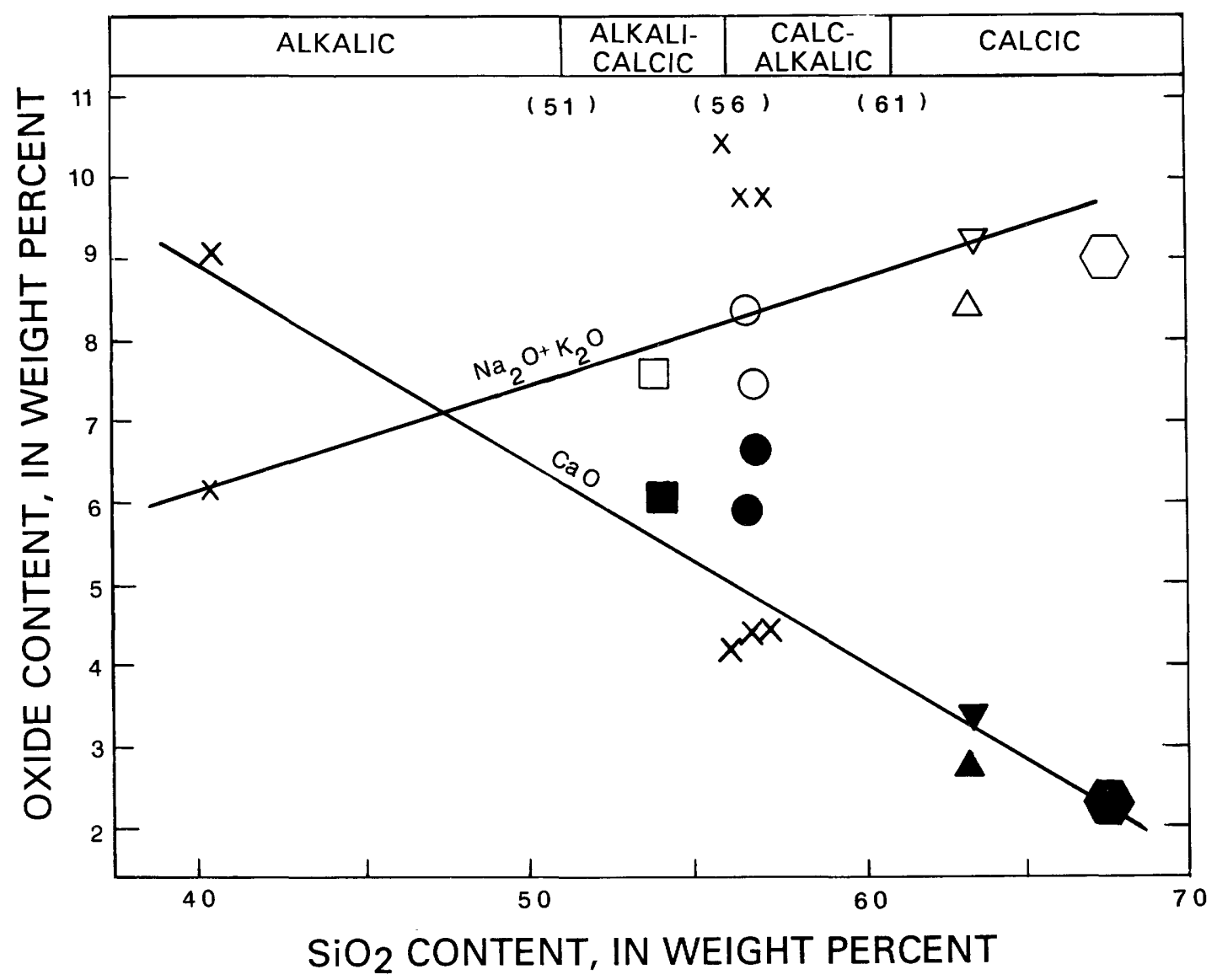

Figure 3. Silica variation diagram of granitoid rocks in western part of Livengood 1:250,000-scale quadrangle showing alkali-lime index of Peacock (1931), which is percent silica where $\mathrm{CaO}$ equals $\mathrm{Na}_{2} \mathrm{O}+\mathrm{K}_{2} \mathrm{O}$. See figure 2 for symbol explanation; solid or bold symbols represent $\mathrm{CaO}$. 
Table 1. Chemical analyses, in weight percent, of major elements, and CIPW norms of representative samples of some granitoid rocks in western Livengood quadrangle

[Elements determined by X-ray fluorescence; DI, differentiation index of Thornton and Tuttle (1960): NRM CI, normative color index; -, no data; LOI, loss on ignition. All field numbers prefixed 87ARi-, except ${ }^{*}$, which are prefixed 88ARi-]

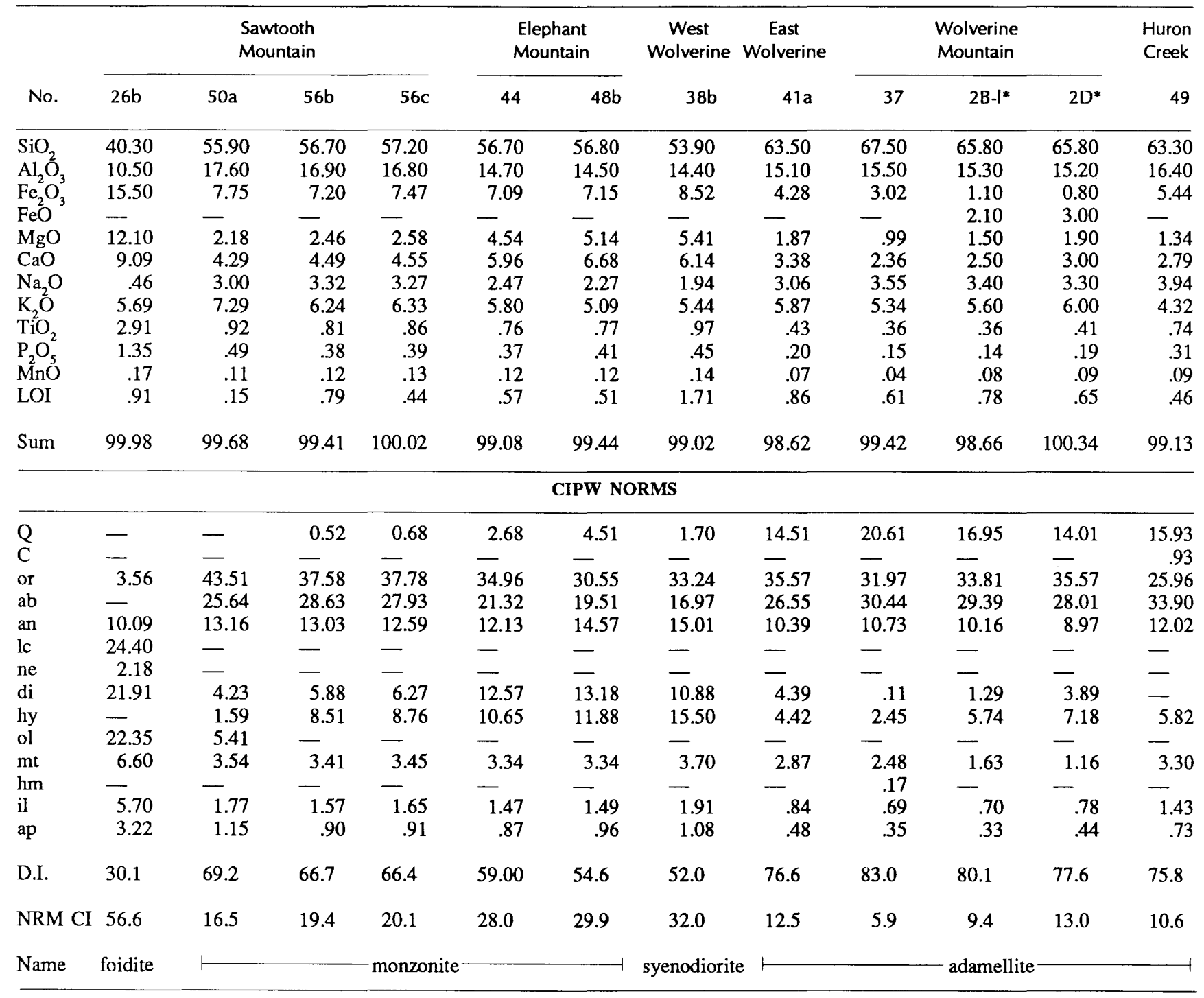

at depth, owing to the greater likelihood of wallrock assimilation as well as deuteric modification at this level. From the evidence of the relict mortar structure, emplacement of the pluton apparently was not entirely passive. Although absence of, or poor exposures of, wallrock preclude obtaining structural evidence bearing on the manner of emplacement for any of the six plutons, several features indicate that they were intruded nearly vertically rather than at a shallow angle, that is, controlled by the dip of thrust faults. These features include: (1) except for Elephant Mountain, generally equant or subequant map pattern of each pluton, with each at the top of a similarly equant or subequant steep topographic high; (2) no mappable planar or linear primary structures, but abundant local planar primary structures, all with steep or vertical attitude-this is especially notable in the Elephant Mountain and Sawtooth Mountain plutons; (3) relatively symmetrical hornfels envelopes; and (4) striking discordancy of the Sawtooth Mountain pluton.

\section{ECONOMIC GEOLOGY}

The only previously reported mineral deposit in the Cretaceous plutons of the western Livengood quadrangle is a stibnite deposit near the summit of Sawtooth Mountain that yielded a small amount of antimony ore (Joesting, 1943; Cobb, 1972). A minor amount of stibnite was reported from a mafic dike near Wolverine Mountain (Berg and Cobb, 1967), but we were unable to locate this 


\begin{tabular}{|c|c|c|}
\hline Pluton & Composition & Texture and structure \\
\hline $\begin{array}{l}\text { Sawtooth } \\
\text { Mountain }\end{array}$ & $\begin{array}{l}\text { Mainly monzonite and syenite, but } \\
\text { with variation to quantitatively } \\
\text { lesser dioritic and gabbroic rocks, } \\
\text { many with lamprophyric compo- } \\
\text { sitions. Quartz free to quartz poor; } \\
\text { locally olivine and orthopyroxene } \\
\text { bearing. }\end{array}$ & $\begin{array}{l}\text { Dramatically developed coarse trachytoid texture, } \\
\text { K-feldspar tablets locally several centimeters } \\
\text { across, parallel to each other, imparting a } \\
\text { local gneissic structure. Conspicuous 1-cm } \\
\text { biotite oikocrysts, randomly oriented, in } \\
\text { otherwise fine-grained phase, occur widely. }\end{array}$ \\
\hline $\begin{array}{l}\text { Elephant } \\
\text { Mountain }\end{array}$ & $\begin{array}{l}\text { Mainly monzonite, quartz poor. } \\
\text { Locally contains orthopyroxene as } \\
\text { well as clinopyroxene. Marked } \\
\text { variation in composition but less } \\
\text { extreme than Sawtooth Mountain. } \\
\text { Color index approximately } 30 \\
\text { (clinopyroxene and biotite; lesser } \\
\text { hornblende). }\end{array}$ & $\begin{array}{l}\text { Trachytoid texture present but not as strongly } \\
\text { developed as in Sawtooth Mountain pluton, } \\
\text { and not as coarse grained. Biotite oikocrysts } \\
\text { in fine-grained phases similar to Sawtooth } \\
\text { Mountain pluton. }\end{array}$ \\
\hline $\begin{array}{l}\text { West } \\
\text { Wolverine }\end{array}$ & $\begin{array}{l}\text { Monzonite and quartz monzonite; } \\
\text { quartz, } 2-6 \text { percent; color index, } \\
25-40 \text { (hornblende and biotite } 1: 1 \text {, } \\
\text { to clinopyroxene and biotite } 3: 1 \text { ). }\end{array}$ & $\begin{array}{l}\text { Massive, varied textures. Fairly fine trachytoid } \\
\text { with } \mathrm{K} \text {-feldspar tablets } \leq 12 \mathrm{~mm} \text { by } 1 \mathrm{~mm} \text {, in } \\
\text { a matrix containing hornblende and clino- } \\
\text { pyroxene }(1: 1) \text {, with variation to a porphyritic } \\
\text { rock consisting of equant } \leq 8 \mathrm{~mm} \text { phenocrysts } \\
\text { of biotite and clinopyroxene in a feldspar matrix; } \\
\text { some finer equigranular, fairly dark phases, locally, } \\
\text { within short distances of wallrock contacts. }\end{array}$ \\
\hline $\begin{array}{l}\text { Wolverine } \\
\text { Mountain }\end{array}$ & $\begin{array}{l}\text { Quartz monzonite; homogeneous; } \\
15-17 \text { percent quartz; color index, } \\
12 \pm 2 \text { (biotite and hornblende). }\end{array}$ & $\begin{array}{l}\text { Homogeneous porphyritic texture; massive; } 30-35 \\
\text { percent euhedral, blocky K-feldspar phenocrysts } \\
\text { average } \leq 1 \mathrm{~cm} \text {. A minor amount of K-feldspar } \\
\text { is late interstitial in matrix. }\end{array}$ \\
\hline $\begin{array}{l}\text { East } \\
\text { Wolverine }\end{array}$ & $\begin{array}{l}\text { Quartz monzonite; homogeneous. } \\
\text { Quartz, 8-12 percent; color index, } \\
5 \pm 3 \text { (biotite, hornblende, clino- } \\
\text { pyroxene, varied ratios); fine- } \\
\text { grained mafic enclaves; minor } \\
\text { fine-grained felsic(?) phases. }\end{array}$ & $\begin{array}{l}\text { Massive, seriate porphyritic, phenocrysts consisting } \\
\text { of thick tablets of euhedral K-feldspar } \leq 1 \mathrm{~cm} \text { about } \\
35 \text { percent. Trachytoid texture varied weak to } \\
\text { strong, commonly weakly to moderately gneissose. } \\
\text { On stained slabs, equally abundant broad prisms } \\
\text { of plagioclase also seriate but half the size of the } \\
\text { K-feldspar phenocrysts. }\end{array}$ \\
\hline Huron Creek & $\begin{array}{l}\text { Quartz monzonite (peraluminous); } \\
\text { quartz, 3-13 percent; color } \\
\text { index approximately } 13 \text { (bio- } \\
\text { tite and homblende } 1: 1 \text { ). }\end{array}$ & $\begin{array}{l}\text { Massive, porphyritic; euhedral blocky K-feldspar } \\
\text { phenocrysts average } 1 \mathrm{~cm} \text { across, } 15-20 \text { percent. } \\
\text { Stained slabs show plagioclase crystals that } \\
\text { average } 2 \mathrm{~mm} \text { long, } 50-60 \text { percent. Remaining } \\
\text { fine-grained matrix composed of late interstitial } \\
\text { quartz, late K-feldspar, and biotite+hornblende }(1: 1) \text {, } \\
\text { in about equal amounts. }\end{array}$ \\
\hline
\end{tabular}

occurrence. Berg and Cobb (1967) also report elevated values for antimony in geochemical samples from near Elephant Mountain. In addition, Mertie (1934) and Waters (1934) reported $\mathrm{Au}, \mathrm{Hg}, \mathrm{Sn}$, and $\mathrm{W}$ in a placer deposit about $6 \mathrm{~km}(4 \mathrm{mi})$ northeast of Wolverine Mountain. At the southern outcrop area of the Huron Creek pluton, molybdenite occurs as discrete crystals in small quartz stringers within the pluton and along the contacts between the pluton and the metamorphic rocks. The mineral identifications were verified by X-ray diffraction (E.A. Bailey, U.S. Geological Survey, written commun., 1988). The mineralized rock was found near the base of a broad talus apron $250 \mathrm{~m}$ west of the ridgecrest and was observed over a north-south distance of $100-120 \mathrm{~m}$. The molybdenite is present in severalmillimeter-diameter aggregates and as scattered grains as long as 1 millimeter in irregular, thin (1 mm wide) quartz veinlets. On surfaces where the rock has broken along one of the molybdenite-bearing veinlets, the molybdenite has a disseminated appearance. Molybdenite was not observed to occur as disseminated grains, and it is not known whether or not it is restricted to the quartz veinlets. The molybdenite-bearing quartz veinlets may represent the uppermost part of a buried mineralized 
stockwork vein system. Molybdenite also occurs near the crest of the ridge in an outcrop of the pluton along its southern contact with the metamorphic rocks.

Abundant scheelite and barite, minor cerussite, and visible gold were observed in heavy mineral concentrate samples from the vicinity of the Huron Creek pluton (R.B. Tripp, U.S. Geological Survey, written commun., 1988). Mineralogy and selected analytical data from semiquantitative spectrographic analysis of the heavy-mineral concentrate samples and rock samples from the Huron Creek pluton are given on table 3; sample localities are shown on figure 4. Arsenic, boron, copper, lead, molybdenum, tin, and tungsten were found to be anomalously high in several of the samples. These metal associations suggest a potential for ore-related mineralization associated with the pluton.

The higher silica content of the Wolverine, East Wolverine, and Huron Creek plutons suggests that they would be the most likely of the plutons in the western

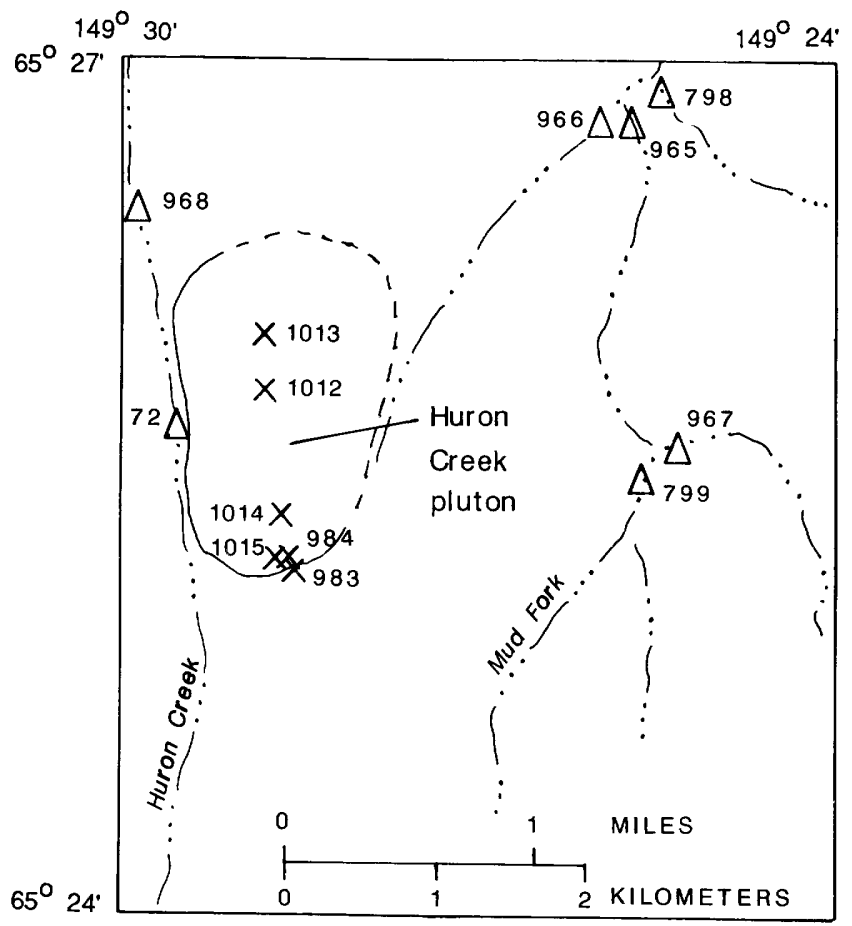

EXPLANATION

Contact--Dashed where approximately located

Sample locality--Numbers refer to table 3

$\times 983 \quad$ Rock

$\triangle 799 \quad$ Heavy mineral concentrate

Figure 3. Sample localities from Huron Creek pluton and adjacent area in Livengood B5 1:63,360-scale quadrangle.
Table 3. Mineralogy and selected analytical data for samples from the Huron Creek pluton and vicinity

[All data in parts per million except where indicated as percent (pct); - indicates no anomalous values; mineralogy by R.B. Tripp (U.S. Geological Survey, Denver, Co., written commun., 1988)]

\begin{tabular}{|c|c|}
\hline Locality & Anomalous samples \\
\hline & Rock samples (Quartz monzonite) \\
\hline 983 & $\mathrm{~B}, 50$ \\
\hline 984 & $\mathrm{~B}, 100 ; \mathrm{Cu}, 100 ; \mathrm{Mo}, 30 ; \mathrm{Sn}, 500$ \\
\hline 1012 & As, 2,$000 ; \mathrm{Pb}, 100 ; \mathrm{Sn}, 30$ \\
\hline 1013 & $\mathrm{Sn}, 30$ \\
\hline 1014 & $\mathrm{Cu}, 100 ; \mathrm{Mo}, 5$ \\
\hline $1015 \mathrm{~A}$ & Mo, 10 \\
\hline 1015B & Mo, 5 \\
\hline \multirow[t]{2}{*}{$1015 \mathrm{D}$} & As, >10,000; W, 700 \\
\hline & Heavy-mineral concentrate samples \\
\hline 72 & Mo, 50, W, 5000; scheelite, 40 pct \\
\hline 798 & $\mathrm{~Pb}, 10,000$ \\
\hline 799 & $\begin{array}{l}\mathrm{Ag}, 70 ; \mathrm{Ba},>10,000 ; \mathrm{Pb}, 10,000 ; \text { barite, } \\
\quad 80 \text { pct; minor scheelite; minor cerussite }\end{array}$ \\
\hline 965 & - \\
\hline 966 & - \\
\hline 968 & $\begin{array}{l}\mathrm{Ag}, 2 ; \mathrm{Au}, 50 ; \mathrm{B}, 50 ; \mathrm{Ba}, 5,000 ; \mathrm{Mo}, 50 \\
\mathrm{~Pb}, 70 ; \mathrm{W}, 10,000 ; \text { scheelite, } 30 \mathrm{pct} \\
\text { pyrite, } 20 \text { pct; minor gold }\end{array}$ \\
\hline
\end{tabular}

Livengood quadrangle to host porphyry-type mineralization. Although the extent of compositional variance in the plutons due to the assimilation of the host rocks they intruded is not known, the major-element data (table 1) indicate that the plutons have too little $\mathrm{SiO}_{2}$ and too much $\mathrm{CaO}$ for a porphyry-Mo-type deposit. Therefore, any porphyry-type mineralization would most likely be of the $\mathrm{Cu}$-Mo type. Although we saw no evidence to suggest the presence of polymetallic veins, there is a possibility that veins containing base and precious metals developed where hydrothermal fluids were confined to restricted channels. In addition, there is a possibility for the occurrence of skarn deposits where calcareous rocks within the Amy Creek(?) unit have been intruded by the Huron Creek pluton.

\section{CONCLUSIONS}

The geochemical signature expressed by regional reconnaissance samples, the small mineral-bearing veinlets, possibly indicative of stockwork mineralization, and the likelihood that the Huron Creek pluton represents a high-level cupola in a larger plutonic complex, all suggest a potential for porphyry-type mineralization at depth, possibly accompanied by base- and preciousmetal-bearing veins and by skarn mineralization around the periphery of the pluton. The most likely mineral 
deposit types expected to occur in this geologic environment would be porphyry copper-molybdenum or polymetallic veins. However, the Huron Creek pluton appears to have been a fairly dry intrusion, and the lack of extensive hydrothermal alteration suggests that the mineralizing system was not well developed. More detailed geochemical sampling and petrographic examination of the other plutons in the western Livengood quadrangle are needed to define the character and extent of mineralization more clearly.

\section{REFERENCES CITED}

Berg, H.C., and Cobb, E.H., 1967, Metalliferous lode deposits of Alaska: U.S. Geological Survey Bulletin 1246, 254 p.

Chapman, R.M., Weber, F.R., and Tabor, Bond, 1971, Preliminary geologic map of the Livengood quadrangle, Alaska: U.S. Geological Survey Open-File Report 71-66, scale 1:250,000.

Cobb, E.H., 1972, Metallic mineral resource map of the Livengood quadrangle, Alaska: U.S. Geological Survey Miscellaneous Field Studies Map MF-413, scale $1: 250,000$.

Dalrymple, G.B., 1979, Critical tables for conversion of K-Ar ages from old to new constants: Geology, v. 7, p. 558-560.

Irvine, T.N., and Baragar, W.R.A., 1971, A guide to the chemical classification of the common volcanic rocks: Canadian Journal of Earth Sciences, v. 8, p. 523-548.

Joesting, H.R., 1943, Supplement to Pamphlet No. 1-Strategic mineral occurrences in interior Alaska: Alaska Department of Mines Pamphlet 2, 28 p.

Le Bas, M.J., Le Maitre, R.W., Streckeisen, A., and Zanettin, B., 1986, A chemical classification for volcanic rocks based on the total alkali-silica diagram: Journal of Petrology, v. 27 , p. $745-750$.
Le Maitre, R.W., 1976, The chemical variability of some common igneous rocks: Journal of Petrology, v. 17, p. $589-637$.

Mertie, J.B., Jr., 1934, Mineral deposits of the Rampart and Hot Springs districts, Alaska: U.S. Geological Survey Bulletin 844-D, p. 163-226.

Nockolds, S.R., 1954, Average chemical compositions of some igneous rocks: Geological Society of America Bulletin, v. 65 , no. 10 , p.1007-1032.

Peacock, M.A., 1931, Classification of igneous rocks series: Journal of Geology, v. 39, no. 1, p. 54-67.

Peccerillo, A., and Taylor, S.R., 1976, Geochemistry of Eocene calc-alkaline volcanic rocks from the Kastamonn area northern Turkey: Contributions to Mineralogy and Petrology, v. 58, p. 63-81.

Streckeisen, A.L., 1973, Plutonic rocks-Classification and nomenclature recommended by the IUGS Subcommission on the systematics of igneous rocks: Geotimes, v. 18, no. 10 , p. $26-30$.

Streckeisen, A.L., and Le Maitre, R.W., 1979, A chemical approximation to the modal QAPF classification of the igneous rocks: Neues Jahrbuch für Mineralogie, v. 136, p. 169-206.

Thornton, C.P., and Tuttle, O.P., 1960, Chemistry of igneous rocks I.Differentiation Index: American Journal of Science, v. 258,p. 664-684.

Wahrhaftig, Clyde, 1965, Physiographic divisions of Alaska: U.S. Geological Survey Professional Paper 482, 52 p.

Waters, A.E., Jr, 1934, Placer concentrates of the Rampart and Hot Springs districts: U.S. Geological Survey Bulletin 844-D, p. 227-246.

\section{Reviewers:}

W.J. Keith

W.H. White 


\title{
Stratigraphy and Palynology of an Upper Tertiary Terrace Deposit of the Ancestral Yukon River Near Circle, Alaska
}

\author{
By Warren Yeend, Thomas A. Ager, and J.T. Kline
}

\begin{abstract}
Terrace deposits of the ancestral Yukon River are exposed in roadcuts and borrow pits along the Steese Highway southwest of Circle, Alaska. As much as 21 meters of unconsolidated sand, gravel, and silt makes up the Birch Creek bridge section, formerly the best of these exposures but now covered. Well-sorted and well-rounded gravel in the lower part of the section has types and abundances of resistant clasts and heavy minerals resembling gravel being transported by the Yukon River today and may represent reworked lower Tertiary materials. The upper part of the sequence is characterized by the presence of a coarse Pleistocene alluvial gravel capped with sand and silt. Pollen and spore assemblages recovered from samples from organic-rich fine-grained sediment lenses suggest a probable Pliocene age for the lower gravels in the deposits. Pollen types in the samples include Pinus, Picea, Abies, Tsuga, Larix, Betula, Alnus, and Diervilla. The pollen data suggest that the regional vegetation was dominated by a diverse conifer assemblage that includes several taxa that no longer grow in the interior. The presence of taxa such as Abies, Tsuga, and Diervilla suggests that a less continental climate prevailed at the time the gravels were deposited than exists today in the interior. The elevation, map distribution, and age of the terrace deposits indicate that the ancestral Yukon River flowed in much the same position it does today, but that at least $150 \mathrm{~m}$ of downcutting has occurred since Pliocene time.
\end{abstract}

\section{INTRODUCTION}

A study of the gold placers in the adjacent Circle mining district led to the investigation of the borrow pit exposures described in this report. It was hoped that clues useful in ascertaining the Cenozoic history and origin of the placers might be obtained from examining all nearby exposures of unconsolidated deposits. The pit possessing the most complete stratigraphy, and here called the Birch Creek bridge section, is $240 \mathrm{~km}$ northeast of Fairbanks on the Steese Highway about $3 \mathrm{~km}$ east of where the road crosses Birch Creek (fig. 1). Previous workers had alluded to the presence of possible Tertiary age sediments in the area. Mertie (1942) suggested that Pliocene sediments might be found "on the tops of the high terraces overlooking the Yukon." Likewise, Williams (1962) described high-level alluvium, commonly mantled with eolian sediments, in the upland margins of the Yukon Flats, which includes the Birch Creek bridge section. He visited this site in 1949, when it was also a borrow pit, and included a photograph of part of the exposure in his report. Williams also noted the more youthful characteristics of these deposits in comparison to the older Tertiary sedimentary rocks in the area, as described by Mertie (1937), and he thought the highlevel alluvium was probably of late Tertiary or early Quaternary age. The exposures along the Steese Highway described in this report were studied with the idea of dating the deposits and relating them in time to the present position of the Yukon River.

\section{DESCRIPTION OF TERRACE DEPOSITS}

\section{Form and Distribution}

A prominent loess-covered terrace near Circle, Alaska, extends for at least $150 \mathrm{~km}$ and along much of its length forms a barrier separating the courses of lower Birch Creek and the Yukon River (fig. 1). The part of the terrace described in this report forms a generally flattopped arcuate topographic ridge $180 \mathrm{~m}$ high that is crossed by the Steese Highway and is 3 to $17 \mathrm{~km}$ southwest of Circle. Terrace materials are periodically exposed in temporary roadcuts and borrow pits along the Steese Highway. In 1986 and 1987, the best exposure was about $3 \mathrm{~km}$ east of where the highway crosses Birch Creek, informally called the Birch Creek bridge section (figs. 1-3), but this exposure has since been destroyed by bulldozing. Two other borrow pits, which previously exposed the terraces, were also examined (fig. 1).

\section{Stratigraphy of the Birch Creek Bridge Section}

The Birch Creek bridge section was described, measured, and sampled in 1986 and 1987 (figs. 2, 3). It represents the most complete, but not the thickest, 
section of the terrace deposit known. Three units, informally labeled units 1 to 3 , are recognized in the Birch Creek bridge section. The lowermost (unit 1) consists of $12.6 \mathrm{~m}$ of unconsolidated, crossbedded, interlayered, well-sorted beds of pebble gravel, sand, and silt. At least two silt horizons contain organic material such as worn wood fragments, pollen, pine cones, and cone fragments. The pebble gravel is predominantly composed of subrounded to well-rounded granules and pebbles less than $1 \mathrm{~cm}$ in diameter. Pebbles rarely occur up to $2 \mathrm{~cm}$ in diameter. This unit possesses an overall faint to moderate limonitic staining with unstained zones resulting from local concentrations of organic material. Weak cementation has developed in zones near the base of the exposed section, especially in crossbedded medium sand. Textures and bedforms suggest a braided stream environment with channel cut and fill and moderate amplitude fluctuations in flow. Clast lithologies suggest that the material originated primarily in the sedimentary and volcanic terranes to the east, with little or none from the crystalline rocks of the Yukon-Tanana Upland. The unit appears to be widespread, judging from observations of extensive high-level gravel terrace deposits in the vicinity of the Yukon River, which exhibit similar clast compositions, bedforms, and textures. This implies that their source was the ancestral Yukon River. The overlying beds (unit 2) consist of $7 \mathrm{~m}$ of poorly sorted coarse gravel containing well-rounded pebbles, cobbles, and boulders up to $30 \mathrm{~cm}$ across in poorly sorted silt and sand matrix. This unit resembles alluvial gravel exposed elsewhere in the Circle 1:250,000-scale quadrangle, which is presumed to be Pleistocene in age based on its topographic position as terraces bordering active creeks. The section is capped by $0.3 \mathrm{~m}$ of medium- to coarse-grained saltand-pepper sand and $2 \mathrm{~m}$ of brown eolian sand and silt, which exists as a widespread blanket-type deposit bordering the south side of the Yukon River throughout interior Alaska. Pebble counts and heavy-mineral content of pan concentrates for units 1 and 2 are summarized and compared with similar data for the modern Yukon River in table 1. The pebble counts were made on randomly selected clasts ranging in size from 0.5 to $20 \mathrm{~cm}$ in diameter. Over 100 clasts were identified from each sample site. Heavy minerals were collected by hand panning and then identification, and percentages of mineral types were estimated by using a 25 -power binocular microscope.

\section{Other Sections}

A gravel pit about $1.5 \mathrm{~km}$ east of the Birch Creek bridge section (fig. 1, loc. A) was examined in 1980. It contained about $35 \mathrm{~m}$ of sandy pebble gravel similar to that of unit 1 in the Birch Creek bridge section. The gravel is overlain by about $7 \mathrm{~m}$ of coarse gravel and silt

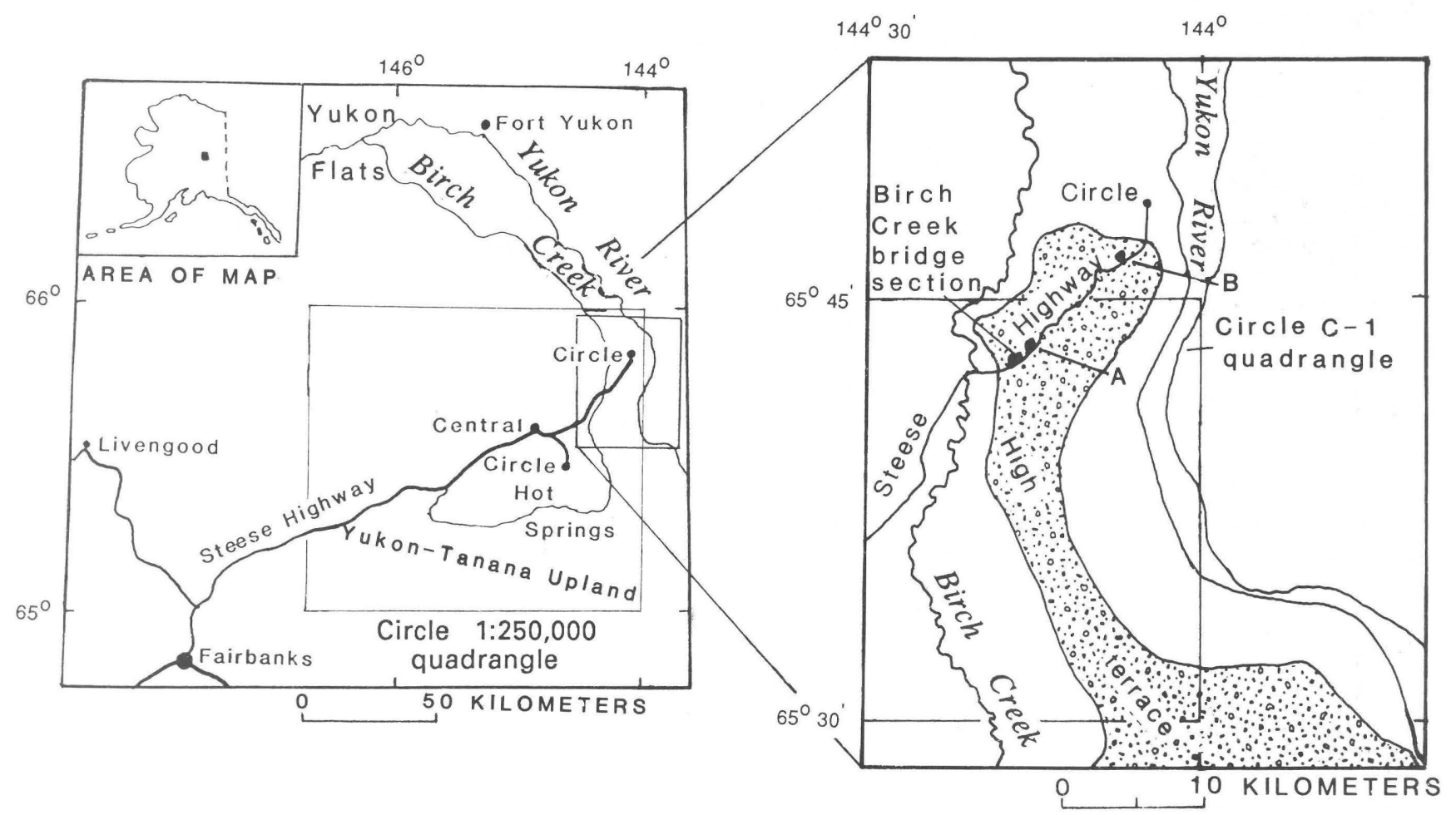

Figure 1. Location of Birch Creek bridge section in Circle C-1 1:63,360-scale quadrangle and map showing arcuate distribution of high terrace along Yukon River and locations of other study localities (A and B). 
similar to units 2 and 3 of the Birch Creek bridge section. Colluvial cover obscured the stratigraphic detail in this pit; consequently, it was not studied as closely as was the Birch Creek bridge section.

A third pit, $15 \mathrm{~km}$ northeast of the Birch Creek bridge section (fig. 1, loc. B), contains $28 \mathrm{~m}$ of unconsolidated sand, gravel, and silt. It was measured, described, and sampled in 1987. The breakdown of the stratigraphy into three units, as was done for the Birch Creek section, would seem to apply to this exposure as well. Twenty-one meters of sandy pebbly gravel is believed to correlate with unit 1 of the Birch Creek bridge section. Pollen collected from a silty-clay bed $3 \mathrm{~m}$ below the upper boundary of the gravel was similar to that collected at the Birch Creek bridge section from unit 1. The pebbly gravel is overlain by $5 \mathrm{~m}$ of boulder gravel correlating with unit 2 at the Birch Creek bridge section, and the exposure is capped by $2 \mathrm{~m}$ of silt correlating with unit 3 .

\section{PALEOBOTANY}

Paleobotanical data from the lower part of the gravel unit provide some insights into the nature of the

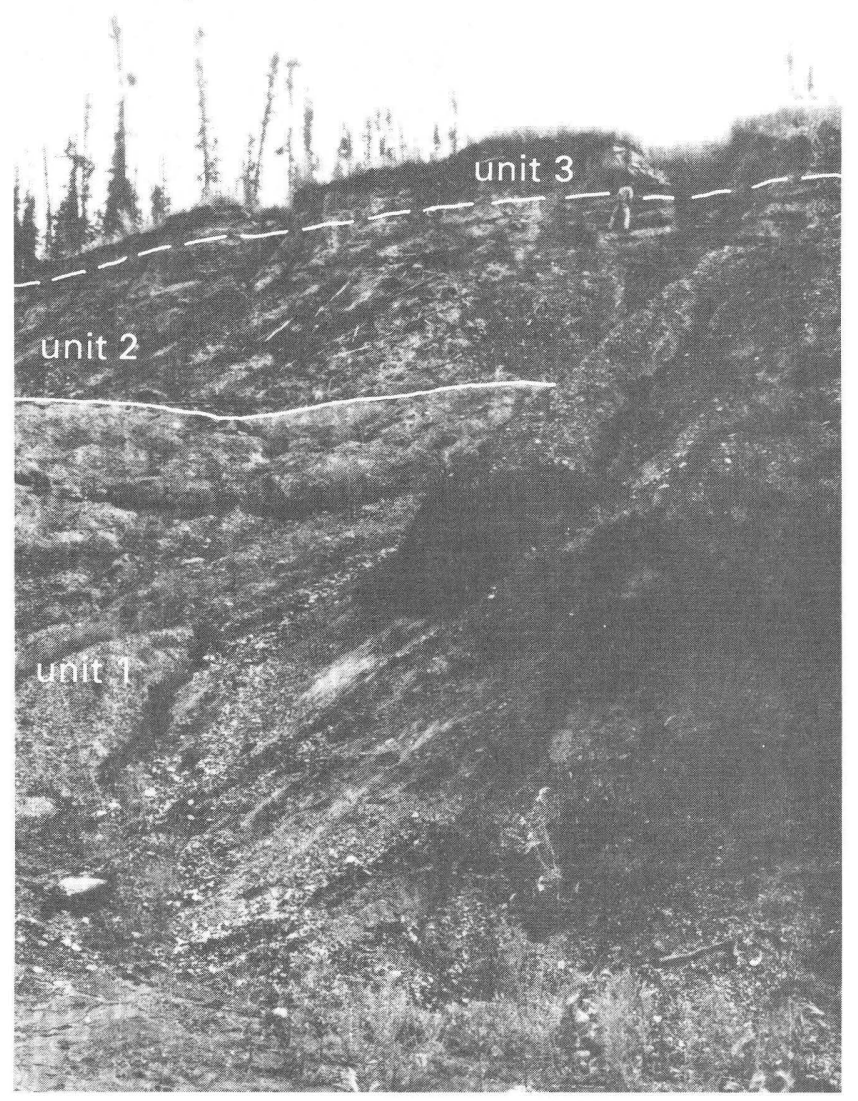

Figure 2. Birch Creek bridge section showing units 1, 2, and 3 discussed in text. regional vegetation during the time of deposition of the gravel. Well-preserved cones were recovered from within layers of iron oxide-stained pebbly sand and silt in the Birch Creek section (figs. 1, 3). Nine cones were identified as Picea and three cones as Larix by Charles Miller, University of Montana (written commun., 1986). Picea and Larix are long-ranging in the geologic record, so their presence conveys no useful age information for the associated deposits. Both taxa grow in the interior of Alaska today, but Larix is now rare in the upper Yukon River area (Hulten, 1968).

\section{PALYNOLOGY}

Twelve samples of fine-grained sediments were collected from two exposures of the gravel unit 1 (fig. 1, Birch Creek bridge section and loc. B; fig. 3). Of these samples, five contained enough fossil pollen and spores to permit analysis of the flora. The palynological evidence suggests a late Neogene, probably early Pliocene, age for the lower gravel unit. No pollen or spores were recovered from the upper gravel unit (unit 2), so its age is uncertain.

The floristic history of the Alaskan flora during the Neogene is best known in southern Alaska, where a sequence of floristic stages has been defined by Wolfe and others (1966) and modified by Wolfe and Tanai (1980). Wolfe's floristic stages for southern Alaska can be applied to sites in interior Alaska, but interpretations and correlations are complicated by differences in regional vegetation resulting from latitudinal and topographical influences. Thus, the Neogene vegetation of interior Alaska was much more conifer-dominated than age-equivalent lowland floras of the Cook Inlet region (Wolfe and Tanai, 1980; Ager, unpub. data).

Pollen and spore types identified from samples at the two exposures are summarized in table 2. Conifer pollen types dominate the pollen samples, and the most abundant conifers represented are Pinus and Picea. Abies, Tsuga, and Larix are consistently represented in the samples, but in small amounts. Only Picea and Larix grow in interior Alaska today (Hulten, 1968). Other pollen types consistently represented in the samples include broadleaf tree and shrub taxa such as Betula, Alnus, Salix, Diervilla, and Ericaceae, all of which occur in the interior today except Diervilla. Diervilla (bush honeysuckle) is a low shrub that no longer grows in Alaska and is found today only as far north as southern British Columbia. Trace amounts of pollen of the broadleaf deciduous tree Pterocarya occur in some of the samples. This temperate-climate tree is known to have persisted in Alaska at least until the late Miocene Homerian Stage of Wolfe (Wolfe and Tanai, 1980). The occurrence of small amounts of Pterocarya pollen in the gravel deposits may be the result of reworking of fossil pollen from older Tertiary deposits in the drainage basin. 
Herbaceous taxa include Gramineae, Cyperaceae, Caryophyllaceae, Onagraceae, and Polemonium. Many herbaceous taxa evolved during the Neogene and are therefore sometimes useful for determining the minimum ages of deposits in which their fossils occur (Muller, 1981). Current evidence suggests that the family Polemoniaceae, which includes the genus Polemonium, first appeared during the Pliocene (Muller, 1981).

The palynological assemblages from the gravel deposits, when compared with other Neogene floras from Alaska, are most similar to those from the Nenana Gravel in the central Alaska Range (Ager, unpub. data). On the basis of limited plant macrofossil evidence, the Nenana Gravel is assigned to the Clamgulchian Stage described for Cook Inlet (Wolfe and others, 1966), now thought to be of latest Miocene to Pliocene age (Wolfe and Tanai, 1980).

The palynological evidence, therefore, suggests that the lower gravel unit (unit 1) exposed along the Steese Highway is equivalent in age to Clamgulchian Stage floras of southern Alaska and the Alaska Range (latest Miocene to Pliocene). However, the occurrence of Polemonium in several samples from the Steese Highway exposures suggests that the deposits are most likely of late Clamgulchian Stage (Pliocene).

\section{DISCUSSION}

The presence of Pliocene gravels here is of interest for several reasons. They record the presence of the ancestral Yukon River in much the same position as it is today, indicating no great change in the locations of the drainage at this locality since the Pliocene. Also, the present elevation of the gravels compared with the present elevation of the Yukon River indicates a minimum of $150 \mathrm{~m}$ of downcutting along this stretch of the Yukon River since Pliocene time. Older Tertiary rocks are present both in the Circle 1:250,000-scale quadrangle (Foster and others, 1983; Mertie, 1937) and the adjacent Charley River 1:250,000-scale quadrangle (Brabb and Churkin, 1969). These rocks, in large part, seem to be

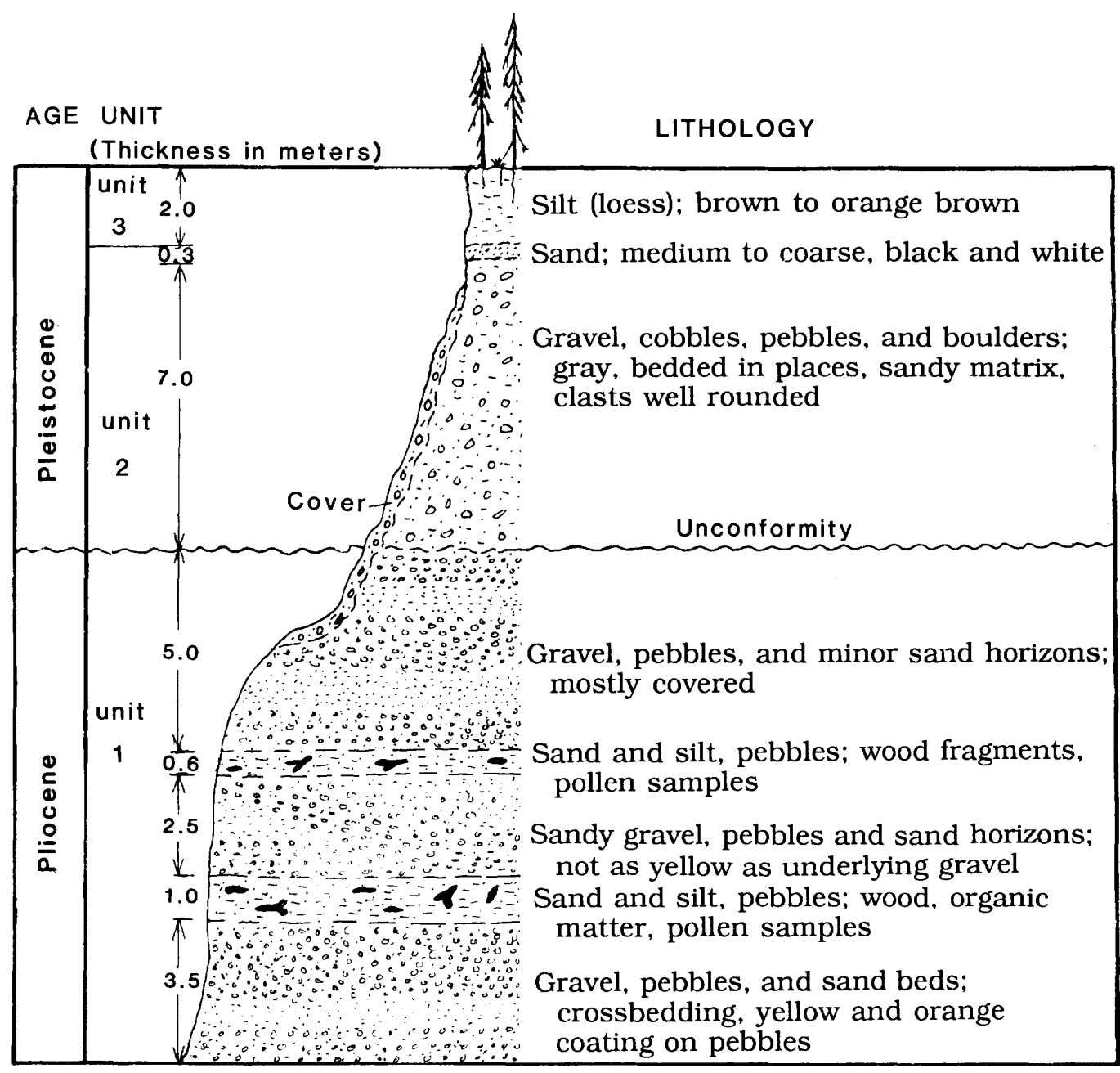

Figure 3. Diagrammatic cross section of Birch Creek bridge section exposed in borrow pit on Steese Highway about $3 \mathrm{~km}$ east of Birch Creek bridge. 
Table 1. Pebble count and heavy mineral percentages from units 1 and 2 of the Birch Creek bridge section and modern Yukon River gravels

[Tr, 2 percent or less]

\begin{tabular}{|c|c|c|c|}
\hline \multirow[b]{2}{*}{ Rock type } & \multicolumn{3}{|c|}{ Pebble count } \\
\hline & $\begin{array}{c}\text { Unit } 1 \\
\text { (161 clasts) }\end{array}$ & $\begin{array}{c}\text { Unit } 2 \\
\text { (114 clasts) }\end{array}$ & $\begin{array}{c}\text { Yukon River } \\
\text { gravel } \\
\text { (148 clasts) }\end{array}$ \\
\hline Argillite & 43 & 25 & 24 \\
\hline Quartzite & 14 & 24 & 20 \\
\hline Chert & 16 & 6 & 12 \\
\hline Sandstone & 4 & 18 & 15 \\
\hline Quartz & 9 & 4 & 7 \\
\hline Greenstone & 2 & 6 & 2 \\
\hline Hypabyssal & 2 & 4 & 1 \\
\hline Orthogneiss & - & 4 & - \\
\hline Tan siltstone & 6 & - & - \\
\hline Granite & - & 3 & 9 \\
\hline Quartz-eye grit & - & 5 & - \\
\hline $\begin{array}{l}\text { Chert pebble } \\
\text { conglomerate }\end{array}$ & 2 & 1 & 3 \\
\hline Graywacke & - & - & 5 \\
\hline Other & 2 & - & 2 \\
\hline $\begin{array}{c}\text { Mineral } \\
\text { (several } \\
\text { samples) }\end{array}$ & \multicolumn{3}{|c|}{ Heavy minerals (percent) } \\
\hline Magnetite & - & 5 & 50 \\
\hline Gamet & 35 to 70 & 20 & 10 \\
\hline Amphibole & 20 to 30 & 5 & 15 \\
\hline Ilmenite & 10 to 40 & 50 & 15 \\
\hline Zircon & $\operatorname{Tr}$ & 10 & $\operatorname{Tr}$ \\
\hline Tourmaline & $\operatorname{Tr}$ & $\mathrm{Tr}$ & - \\
\hline Epidote & $\mathrm{Tr}$ & $\mathrm{Tr}$ & $\mathrm{Tr}$ \\
\hline Chlorite & $\mathrm{Tr}$ & - & $\mathrm{Tr}$ \\
\hline Rock fragments & $\mathrm{Tr}$ & 5 & $\mathrm{Tr}$ \\
\hline Gold & $\mathrm{Tr}$ & - & $\mathrm{Tr}$ \\
\hline
\end{tabular}

localized along the Tintina fault trench and may be genetically related to the trench. In the Circle quadrangle most of these rocks are interpreted as alluvial fan deposits eroded from adjacent highlands (Yeend, 1989). They are clearly older than those gravels of unit 1 in the Birch Creek bridge section, are more indurated, generally contain lignite beds, and commonly are tilted, probably as a result of faulting (Mertie, 1942; Weber and Foster, 1982; Yeend, 1984). These older Tertiary rocks may have provided detritus that was reworked by the ancestral Yukon River into the Pliocene terrace gravels, as both deposits possess similar resistant rock types such as multicolored chert, quartz, and quartzite (Mertie, 1942; Barker, 1986).

\section{CONCLUSIONS}

This study has produced the following conclusions: (1) Fossil pollen data permit assigning a Pliocene age to
Table 2. Fossil pollen and spore assemblages from Birch Creek bridge section and locality $B$

[Analyses by T.A. Ager]

\begin{tabular}{|c|c|c|}
\hline Taxon & $\begin{array}{l}\text { nile Creek } \\
\text { oc. B) }\end{array}$ & $\begin{array}{l}\text { Birch Creek } \\
\text { bridge section }\end{array}$ \\
\hline \multicolumn{3}{|c|}{ Pollen types } \\
\hline Picea (spruce) & $\mathrm{X}$ & $\mathrm{X}$ \\
\hline Pinus (pine) & $\mathrm{X}$ & $\mathbf{X}$ \\
\hline Larix (larch) & $\mathrm{X}$ & $\mathrm{X}$ \\
\hline Abies (fir) & $\mathrm{X}$ & $\mathrm{X}$ \\
\hline Tsuga (hemlock) & $\mathrm{X}$ & $\mathrm{X}$ \\
\hline Betula (birch) & $\mathrm{X}$ & $\mathrm{X}$ \\
\hline Alnus (alder) & $\mathrm{X}$ & $\mathrm{X}$ \\
\hline Pterocarya (wing-nut) & $\mathrm{X}$ & $\mathrm{X}$ \\
\hline Salix (willow) & $\mathrm{X}$ & - \\
\hline $\begin{array}{l}\text { Myrica-Comptonia (sweet } \\
\text { gale-sweetfern) }\end{array}$ & $\mathrm{X}$ & $\mathrm{X}$ \\
\hline Ericaceae (heath family) & $\mathrm{X}$ & $\mathrm{X}$ \\
\hline Diervilla (bush honeysuckle) & $\mathrm{X}$ & $\mathrm{X}$ \\
\hline Caprifoliaceae (honeysuckle family) & $\mathrm{X}$ & $\mathrm{X}$ \\
\hline $\begin{array}{l}\text { Onagraceae (evening primrose } \\
\text { family) }\end{array}$ & $\mathrm{X}$ & - \\
\hline Polemonium (Jacob's ladder) & $\mathrm{X}$ & $\mathrm{X}$ \\
\hline Caryophyllaceae (pink family) & $\mathrm{X}$ & $\mathrm{X}$ \\
\hline Gramineae (grass family) & $\mathrm{X}$ & $\mathrm{X}$ \\
\hline
\end{tabular}

\begin{tabular}{|c|c|c|}
\hline \multicolumn{3}{|c|}{ Spore types } \\
\hline Monolete fern spore types & $\mathbf{X}$ & $\mathrm{X}$ \\
\hline Trilete fern spores & $\mathrm{X}$ & - \\
\hline Lycopodium spp. (club moss) & $\mathrm{X}$ & $\mathrm{X}$ \\
\hline $\begin{array}{l}\text { Selaginella selaginoides } \\
\text { (spike moss) }\end{array}$ & 一 & $\mathrm{X}$ \\
\hline Sphagnum (sphagnum moss) & $X$ & $\mathrm{X}$ \\
\hline
\end{tabular}

the unit 1 gravels of the Birch Creek bridge section, (2) the flora assemblages indicated by the fossil pollen suggest that summer climates here may have been several degrees warmer and somewhat wetter during the growing season than at present, (3) the map distribution and age of the terrace deposits indicate that the ancestral Yukon River flowed in much the same position it does today, and (4) the elevation of the terrace deposits indicates that at least 150 meters of downcutting has occurred since Pliocene time.

\section{REFERENCES CITED}

Barker, J.C. 1986, Placer gold deposits of the Eagle trough, upper Yukon River region, Alaska: U.S. Bureau of Mines Information Circular 9123, $23 \mathrm{p}$.

Brabb, E.E., and Churkin, Michael, Jr., 1969, Geologic map of the Charley River quadrangle, east-central Alaska: U.S. Geological Survey Miscellaneous Geological Investigations Map I-573, scale 1:250,000.

Foster, H.L., Laird, Jo, Keith, T.E.C., Cushing, G.W., and Menzie, W.D., 1983, Preliminary geologic map of the Circle quadrangle, Alaska: U.S. Geological Survey 
Open-File Report 83-0170-A, 32 p., 1 oversize sheet, scale 1:250,000.

Hulten, Eric, 1968, Flora of Alaska and neighboring territories: Stanford, Calif., Stanford University Press, 1008 p.

Mertie, J.B., Jr., 1937, The Yukon-Tanana region, Alaska: U.S. Geological Survey Bulletin 872, 276 p.

1942, Tertiary deposits of the Eagle-Circle District, Alaska: U.S. Geological Survey Bulletin 917-D, p. 221.

Muller, Jan, 1981, Fossil pollen records of extant angiosperms: Botanical Review, v. 47, 142 p.

Weber, F.R., and Foster, H.L., 1982, Tertiary(?) conglomerate and Quaternary faulting in the Circle quadrangle, Alaska, in Coonrad, W.L., ed., The United States Geological Survey in Alaska: Accomplishments during 1980: U.S. Geological Survey Circular 844, p. 58-61.

Williams, J.R., 1962, Geologic reconnaissance of the Yukon Flats district, Alaska: U.S. Geological Survey Bulletin 1111-H, p. 289-331.

Wolfe, J.A., Hopkins, D.M., and Leopold, E.B. , 1966, Tertiary stratigraphy and paleobotany of the Cook Inlet region,
Alaska: U.S..Geological Survey Professional Paper 398A, 29 p.

Wolfe, J.A., and Tanai, T., 1980, The Miocene Seldovia Point flora from the Kenai Group, Alaska: U.S. Geological Survey Professional Paper 1105, 52 p.

Yeend, W.E., 1984, Gold in Tertiary(?) rocks, Circle quadrangle, Alaska, in Coonrad, W.L., and Elliott, R.L., eds., The United States Geological Survey in Alaska-Accomplishments during 1981: U.S. Geological Survey Circular 868, p. 65-66.

1989, Late Cenozoic sedimentary history along major fault zones, Alaska, in Carter, L.D., Hamilton, T.D., and Galloway, J.P., eds., Late Cenozoic interior basins of Alaska and the Yukon: U.S. Geological Survey Circular 1026.

\section{Reviewers:}

R.M. Chapman

H.L. Foster 


\title{
In Search of the Provenance and Paleogeographic Location of the White Mountains Terrane: Evidence from U-Pb Data of Granite Boulders in the Fossil Creek Volcanics
}

\author{
By John N. Aleinikoff and George Plafker
}

\begin{abstract}
The White Mountains terrane of east-central Alaska is mainly composed of the Fossil Creek Volcanics (Ordovician) and the Tolovana Limestone (Silurian). We have attempted to date three boulders of a unique pink granite from conglomerate in the Fossil Creek Volcanics in order to provide evidence for its provenance. U-Pb data from coarse zircons plot as a scatter pattern, possibly due to inherited radiogenic lead. Fine-grained zircon populations form a crude linear array with an upper intercept age of $560 \pm 82 \mathrm{Ma}$, which we interpret as the age of crystallization of the granite. Although lithologic correlation and palinspastic reconstruction suggest that the White Mountains terrane was displaced from the Selwyn basin region of British Columbia by dextral offset along the Tintina fault, no Late Proterozoic to Early Cambrian igneous rocks are known from that area. It is possible that basement rocks of this age are now buried beneath the thick Paleozoic section in the Selwyn basin, or that they were completely eroded or were never there. The provenance of the granite boulders remains an enigma.
\end{abstract}

\section{INTRODUCTION}

The White Mountains terrane of Jones and others (1981) and Churkin and others (1982) is one of a series of small, elongate terranes that extend southwestward from the Tintina fault in central Alaska (fig. 1). The terrane consists predominantly of the Ordovician Fossil Creek Volcanics and the Silurian Tolovana Limestone that crop out mainly in two areas north and south of the Manley and Livengood terranes (fig. 1). The White Mountains terrane is interpreted by Jones and others (1984; 1986; 1987) and Churkin and others (1982) as having an accreted or "suspect" origin. In contrast, Tempelman-Kluit (1984), Wheeler and others (1987), Weber and others $(1987,1988)$, and Pessel and others (1987) interpreted the White Mountains terrane and the adjacent Wickersham terrane (fig. 1) as a continuous stratigraphic sequence of North American cratonal origin. Tempelman-Kluit (1984), Dover (1985), and Wheeler and others (1987) suggest that the two terranes have been offset from lithologically similar strata in the Selwyn basin and Cassiar platform regions of the Yukon by about $450 \mathrm{~km}$ of dextral displacement of the Tintina fault. In this study, we use the lithology and U-Pb ages of unique pink granite clasts that occur locally in conglomerate of the Fossil Creek Volcanics as a possible additional constraint in evaluating displacement histories for the White Mountains terrane.

\section{STRATIGRAPHY AND SAMPLE DESCRIPTION}

The oldest unit of the White Mountains in eastcentral Alaska (fig. 2) is the (informal)Wickersham grit unit, a Late Proterozoic to Cambrian formation, based on the presence of the trace fossil Oldhamia (Weber and others,1985). This unit comprises the Wickersham terrane of Jones and others (1987). The Wickersham grit unit is believed to unconformably underlie the Fossil Creek Volcanics (Wheeler and others, 1987). In most places, the contact is either concealed or faulted; recent mapping indicates that it locally is depositional (Weber and others, 1988). As originally defined by Mertie (1937), the Fossil Creek Volcanics is composed of more than 600 meters of mafic volcanic rocks, agglomerate, conglomerate, and calcareous sandstone (fig. 3). Chapman and others (1971) divided the Fossil Creek Volcanics into a lower sequence consisting mostly of sedimentary rocks (including slate, siltstone, and limestone, with minor mafic volcanic and intrusive rocks) and an upper sequence composed primarily of mafic volcanic rocks. These include alkali basalt, mafic tuff, and agglomerate, which are capped by volcaniclastic sedimentary rocks (Wheeler and others, 1987). Although Churkin and others (1982) ascribed an oceanic (volcanic arc or seamount) origin for basalt of the Fossil Creek Volcanics, the alkalic composition makes an ocean-ridge or islandarc setting unlikely. Wheeler and others (1987, p. 72) concluded that the Fossil Creek Volcanics formed in a "continental margin or shallow marine (shelf) environment." Near the base of the Fossil Creek Volcanics, 
Early Ordovician trilobites and conodonts occur in calcareous slate (Wheeler and others, 1987). Late Ordovician (Ashgillian) brachiopods, corals, and conodonts occur in the uppermost beds (both siliciclastic and calcareous) of the Fossil Creek Volcanics (Blodgett and others, 1987). Disconformably overlying these units is the Silurian Tolovana Limestone (fig. 3; Blodgett and others, 1987; Wheeler and others, 1987).

Conglomeratic layers occur within the upper part of the Fossil Creek Volcanics (fig. 3). In one such layer, the matrix and at least 90 percent of the clasts are reworked mafic volcanic rocks derived locally from the volcanic and volcaniclastic part of the Fossil Creek Volcanics. Other clasts are quartzite, limestone, grit, and pink granite, ranging in diameter from less than 1 centimeter up to about 20 centimeters. The boulders of granite are moderately to well rounded. Other clasts are rounded to angular. Textures within the conglomerate suggest a debris-flow origin. The poor sorting, very coarse maximum size, and occurrence in debris-flow deposits indicate that the clasts were deposited close to their sources. We collected seven of the largest granite clasts for petrologic study and three of these were dated by U-Pb zircon geochronology.

The granite is pink and medium grained, with hypidiomorphic granular texture. It is composed of quartz ( 28 to 41 percent), K-feldspar (30 to 43 percent), plagioclase (16 to 42 percent), minor chlorite (after biotite), and opaque minerals, with trace zircon, apatite, and sphene. K-feldspar mostly occurs in myrmekitic intergrowth with quartz. The plagioclase is almost entirely altered to albite \pm sericite, with polysynthetic twinning only rarely visible. The granite was metamorphosed to greenschist facies after deposition of the conglomerate because both granite clasts and volcanic matrix are now at a similar metamorphic grade. At other localities of the Fossil Creek Volcanics in the study area, Late Ordovician to Silurian conodonts have color alteration indices indicative of heating to at least $300-400{ }^{\circ} \mathrm{C}$ (Blodgett and others, 1987), supporting the petrographic evidence of postdeposition metamorphism.

\section{U-PB GEOCHRONOLOGY}

Individual zircon separates were prepared from three boulders which weighed about 7 kilograms each (table 1). Although the boulders have very similar compositions, subtle differences in grain size and color suggest the remote possibility that the boulders were not from the same source pluton. Therefore, the three boulder samples were not combined into a single bulk sample for isotopic analysis. Because the samples were relatively small and the yield of zircon from each sample was less than about $50 \mathrm{mg}$, we were somewhat limited in our choice of appropriate splits to analyze.

Zircons from the three analyzed samples are subhedral to euhedral, with length-to-width ratios of about 1 to 4. About 50 percent of the crystals lack pyramidal terminations and have jagged, broken ends. All grains are light tan. In the coarser fractions, many zircons contain dark, round (resorbed?) cores (fig. 4). Cores are mostly absent in the finer fractions. The outer areas of cored zircons are finely zoned, indicating an igneous origin. This morphology suggests the growth of igneous rims over inherited xenocrystic zircon, implying the potential for complicated U-Pb systematics.

Extraction of uranium and lead from zircons utilized a slightly modified version of the method of Krogh (1973). Lead was loaded on a single rhenium filament

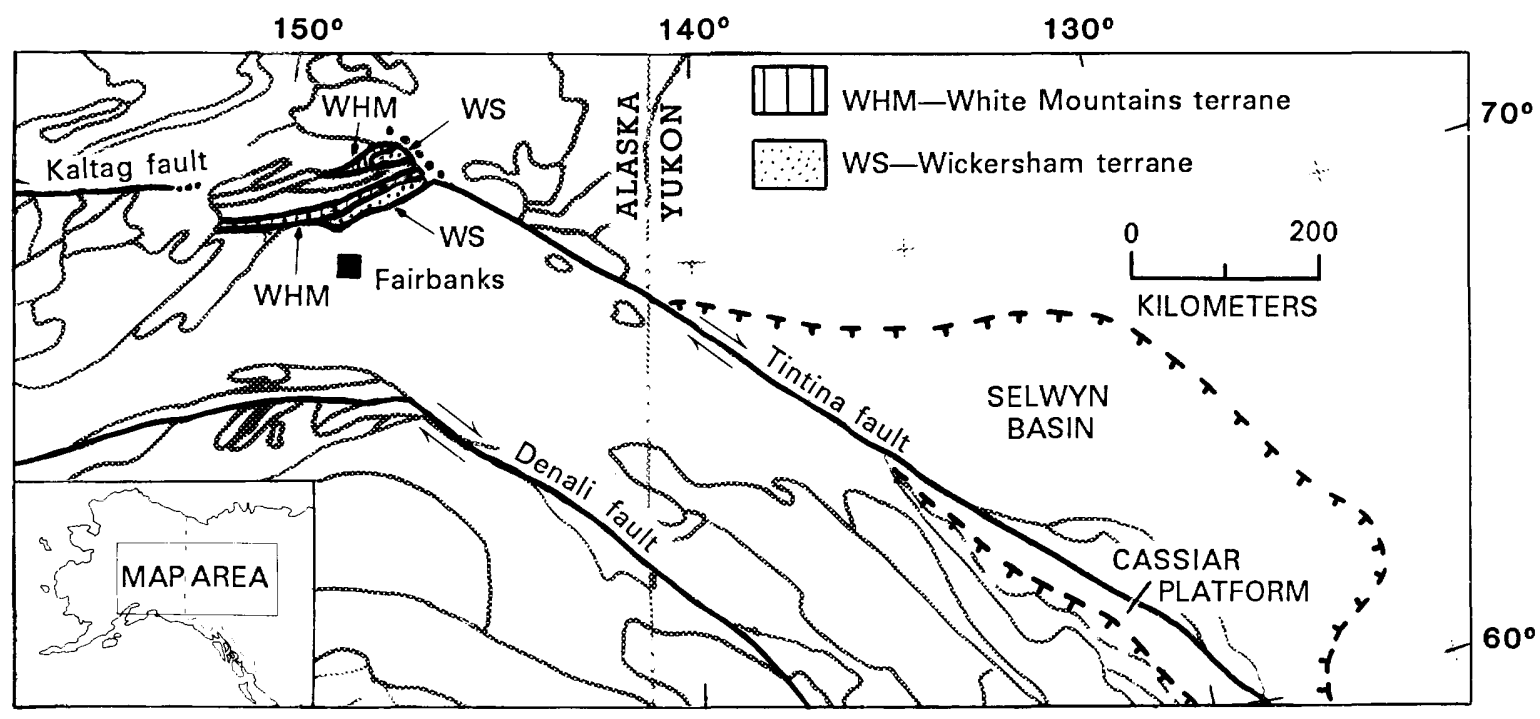

Figure 1. Locations of White Mountains and Wickersham terranes of east-central Alaska (from Jones and others, 1984 ; 1987) and adjacent areas of Canada. 
assembly with $0.15 \mathrm{~N}_{3} \mathrm{PO}_{4}$ and silica gel; uranium was loaded with $0.5 \mathrm{~N} \mathrm{HNO}_{3}$ on a triple rhenium filament assembly. All isotopic ratios were measured on an automated VG 54E mass spectrometer with Daly multiplier. Uncertainties in measured ${ }^{206} \mathrm{~Pb} /{ }^{207} \mathrm{~Pb}$ and ${ }^{206} \mathrm{~Pb} /{ }^{208} \mathrm{~Pb}$ are less than 0.08 percent and mostly in the range 0.02 to 0.05 percent. Uncertainties in measured ${ }^{206} \mathrm{~Pb} /{ }^{204} \mathrm{~Pb}$ are less than 0.2 percent. Calculated uncertainties in ${ }^{206} \mathrm{~Pb} /{ }^{238} \mathrm{U}$ and ${ }^{207} \mathrm{~Pb} /{ }^{235} \mathrm{U}$ (table 1) are 0.56 to 0.60 percent; calculated uncertainties in ${ }^{207} \mathrm{~Pb} /{ }^{206} \mathrm{~Pb}$ (table 1) are 0.07 to 0.14 percent. Data were reduced and plotted using programs of Ludwig $(1980,1987)$.

Uranium concentrations for all 10 fractions from the three boulders are relatively low, ranging from about 174 to $379 \mathrm{ppm}$. The isotopic systematics (fig. 5) and uranium contents of these splits are similar and indicate that the three boulders come from the same granite source. ${ }^{207} \mathrm{~Pb} /{ }^{206} \mathrm{~Pb}$ ages range from 485 to $813 \mathrm{Ma}$. However, the data do not form a linear array. After our initial analyses of four different size fractions from sample 87APr 122E (table 1), it was apparent that the dark material in the cores of some coarser zircons contained inherited radiogenic lead. Because the data formed a scatter pattern on the concordia plot, little information was obtained initially for either the upper or lower intercept. Additional splits, from two other boulders, involved only the finest zircons in an effort to avoid inheritance present in the coarser fractions. The relative degree of discordance of individual splits is directly correlative with uranium content.

A best-fit line calculated through five relatively colinear fractions of fine-grained zircon has concordia intercept ages of $560 \pm 82$ and $180 \pm 140 \mathrm{Ma}$. The large uncertainty in the upper intercept is probably due to a combination of factors, including minor inheritance of radiogenic lead and a large amount of lead loss, despite the relatively low concentrations of uranium in the zircons. To minimize the contribution of inherited lead, we analyzed rim (igneous) material by collecting dust removed from zircon grains by abrasion in a ceramic mill. Unfortunately, some of the abraded zircons were broken and therefore, some core material was also removed. The resulting isotopic data (including a ${ }^{207} \mathrm{~Pb} /{ }^{206} \mathrm{~Pb}$ age of $606 \mathrm{Ma}$ ) represent a mixture of core and rim ages. We

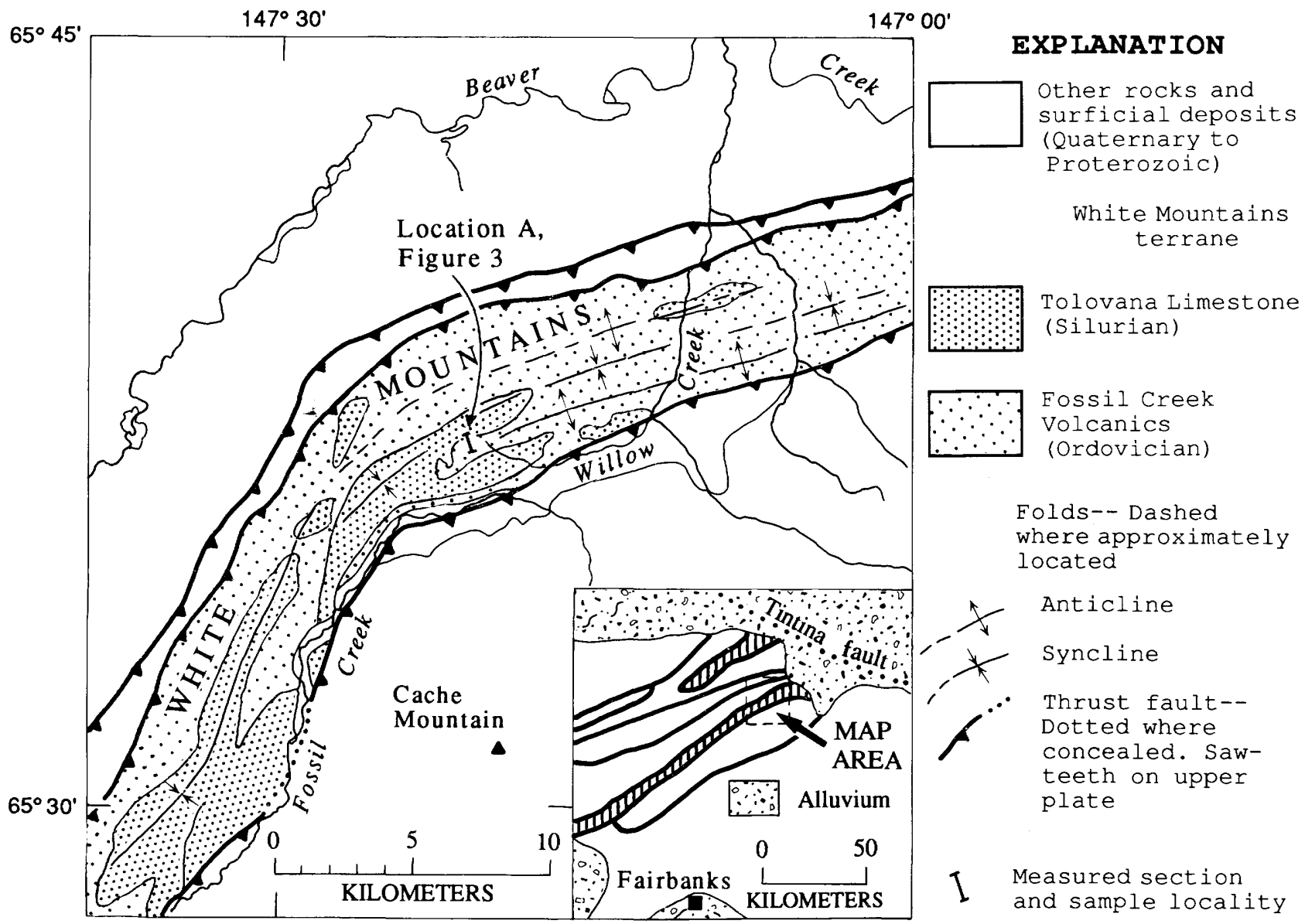

Figure 2. Generalized geologic map of study area in White Mountains in Livengood C-1 and C-2 quadrangles, showing location of measured section and samples (fig. 3). Modified from Wheeler and others (1987). See figure 1 for location of study area. 
interpret the concordia intercept ages to indicate a crystallization age for the granite of $560 \pm 82 \mathrm{Ma}$. However, a clustering of ${ }^{207} \mathrm{~Pb} /{ }^{206} \mathrm{~Pb}$ ages in the finest zircons near about 500 Ma suggests that this may be a closer approximation of the age of the granite provenance. The lower intercept age may represent the time of postdepositional metamorphism, previously described, although the large uncertainty does not firmly constrain when this metamorphism occurred. The systematic decrease in ${ }^{207} \mathrm{~Pb} /{ }^{206} \mathrm{~Pb}$ age with increasing degree of discordance suggests that episodic lead loss occurred in the past, and that the discordant data array is not due to modern lead loss alone. This non-zero age for the lower intercept may be the time at which metamorphism modified the conodont color alteration index.

\section{DISCUSSION}

The goal of this study is to describe and date boulders of granite that occur in a conglomerate whose age is independently well constrained, in order to find the boulder provenance, and thereby a possible source area, for the White Mountains terrane. Inherent in this effort is the hope that the geochronologic results will be both definitive and unique so that no ambiguity exists in the correlation of units. Unfortunately, the age data are complicated by a large degree of discordance, perhaps induced by Mesozoic metamorphism, and scatter probably due to inheritance of radiogenic lead. Although we are able to estimate the crystallization age, the additional information of the age of inheritance (the age of the source of the granite boulders) is not obtainable from our scattered data. The only constraint is that the age of the source rock for the granite is at least $813 \mathrm{Ma}$ (based on the oldest ${ }^{207} \mathrm{~Pb} /{ }^{206} \mathrm{~Pb}$, table 1 ), and it is of continental affinity (based on composition and on associated quartzite clasts and alkalic volcanic rocks). However, it is likely that the source is significantly older. An additional hindrance is that the age of the granite is too unique; no granites of comparable age are known anywhere in the North American Cordillera.

Palinspastic reconstructions suggest that terranes south of the northern part of the Tintina fault system underwent about $450 \mathrm{~km}$ of right-lateral displacement, based on dextral offsets of Paleozoic facies boundaries

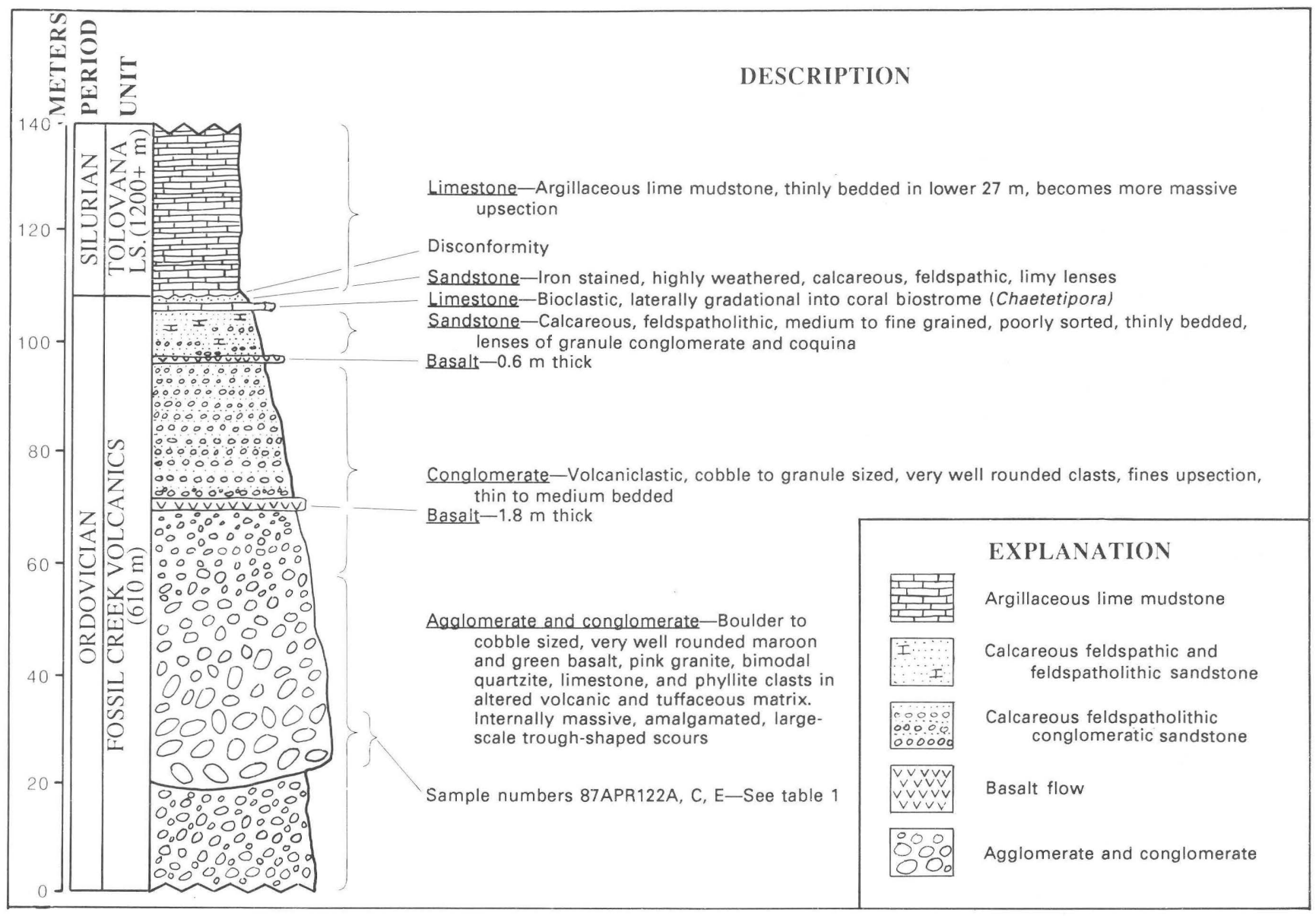

Figure 3. Measured stratigraphic section in upper part of the Fossil Creek Volcanics and lower part of the Tolovana Limestone showing location of granite boulder samples. Modified from Wheeler and others (1987). 
Table 1. Uranium-lead concentration and composition data from zircon from granite boulders in a conglomerate layer within the Fossil Creek Volcanics, White Mountains terrane, east-central Alaska

[Location of boulders A, C and E: $65^{\circ} 37.2^{\prime} \mathrm{N}, 147^{\circ} 21.2^{\prime} \mathrm{W}$. Constants: ${ }^{235} \lambda=9.8485 \times 10^{-10} \mathrm{yr}^{-1} ;{ }^{298} \lambda=1.55125 \times 10^{-10} \mathrm{yr}^{-1} ;{ }^{238} \mathrm{U} /{ }^{235} \mathrm{U}=137.88$ (Steiger and Jäger, 1977)]

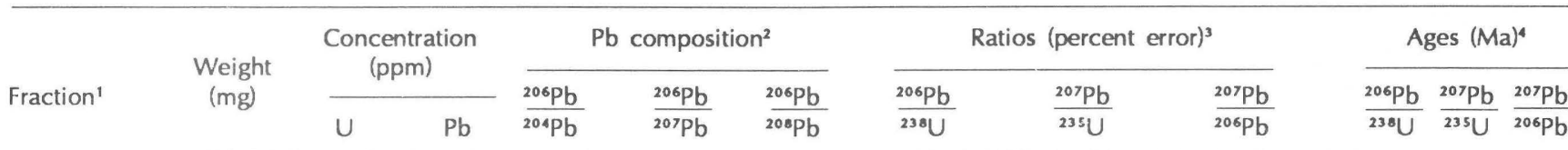

87APr 122A

\begin{tabular}{|c|c|c|c|c|c|c|c|c|c|c|c|}
\hline$(-325+400) \mathrm{NMD}$ & 0.99 & 183.9 & 13.61 & 6118.5 & 16.631 & 6.4669 & $.07087(.59)$ & $.56434(.60)$ & $.05775(.14)$ & 441 & 454 \\
\hline$(-400) N M$ & 1.22 & 230.9 & 16.75 & 1038.2 & 14.033 & 5.6482 & $.06632(.57)$ & $.52342(.60)$ & $.05724(.19)$ & 414 & 427 \\
\hline$(-400) \mathrm{Mag}$ & 1.38 & 296.5 & 20.33 & 4310.1 & 16.456 & 6.6950 & $.06559(.56)$ & $.51904(.57)$ & $.05739(.09)$ & 410 & 425 \\
\hline \multicolumn{12}{|c|}{ 87APr 122C } \\
\hline$(-400) N M$ & 1.30 & 369.9 & 23.76 & 28750 . & 17.437 & 6.7619 & $.06189(.56)$ & $.48503(.56)$ & $.05684(.08)$ & 387 & 401 \\
\hline$(-400) \mathrm{Mag}$ & 1.59 & 294.5 & 21.25 & 664.27 & 12.441 & 4.8238 & $.06327(.56)$ & $.51026(.57)$ & $.05849(.13)$ & 395 & 419 \\
\hline
\end{tabular}

\begin{tabular}{|c|c|c|c|c|c|c|c|c|c|c|c|c|}
\hline$(-1$ & 2.49 & 177.7 & 13.69 & & 13.468 & 5.2151 & & & $.06622(.10)$ & 436 & 502 & 813 \\
\hline & & & & & & & & & & 4 & 482 & 609 \\
\hline & 6.2 & & & & & & & & & 428 & 444 & 52 \\
\hline$(-325) \mathrm{NM}$ & 5.19 & 203.4 & 15.07 & 2919.2 & 16.060 & 5.6111 & $.06897(.57)$ & $.54470(.58)$ & $.05728(.07)$ & 430 & 442 & 502 \\
\hline
\end{tabular}

87APr 122E + C

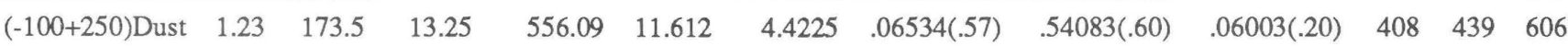

${ }^{1}$ Abbreviations: NM (non-magnetic), D (diamagnetic), Mag (magnetic), Dust (abraded rims collected as dust exhausted from ceramic abrasion mill).

${ }^{2}$ Corrected for $1 \mathrm{ng}$ blank and mass fractionation of $0.14 \pm .05$ percent/atomic mass unit.

${ }^{3} 2 \sigma$ errors.

${ }^{4}$ Common lead corrected for using appropriate values from Stacey and Kramers (1975).

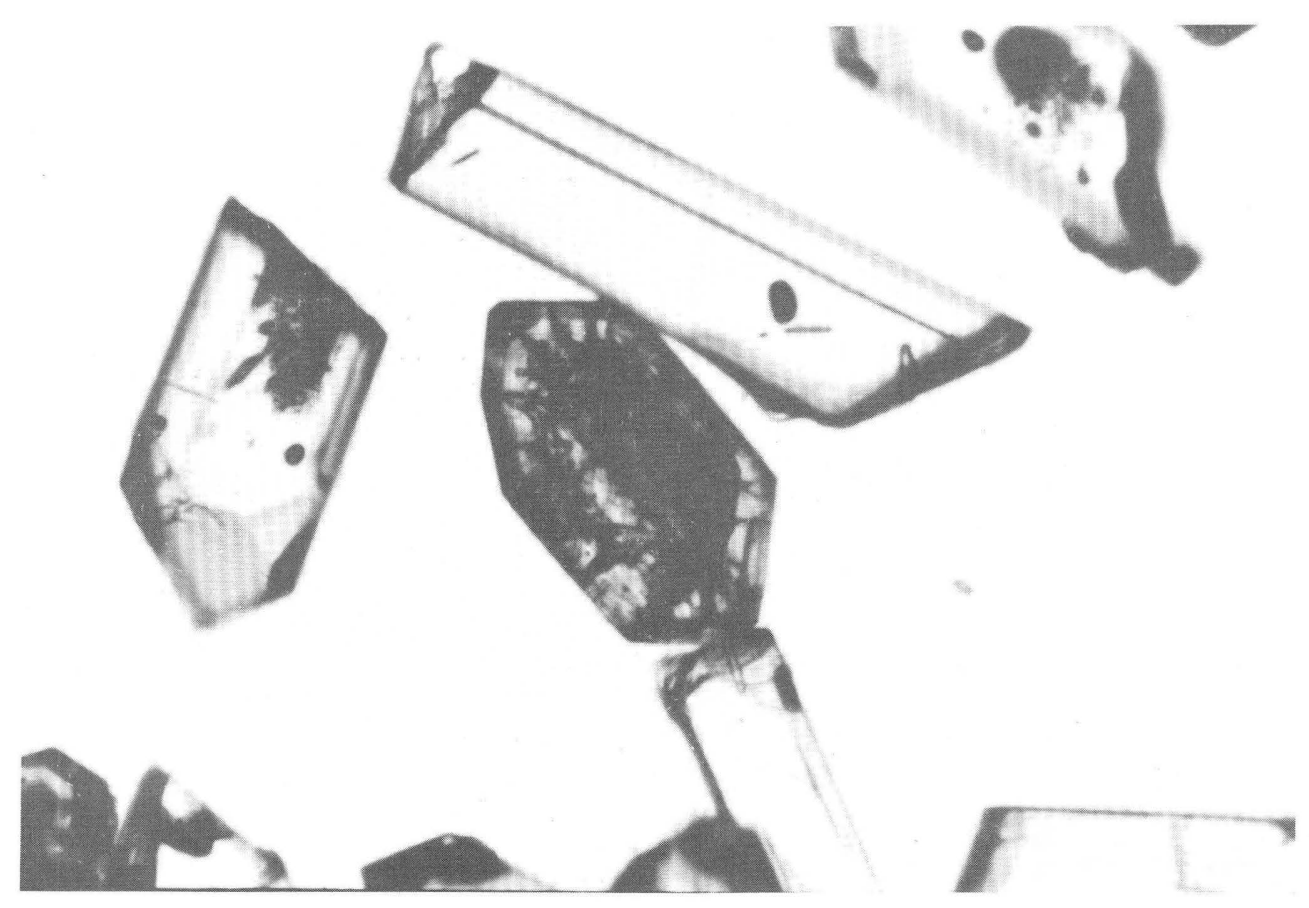

Figure 4. Photomicrograph of zircons from $-200+250$ mesh size fraction from sample $87 \mathrm{APr}$ $122 \mathrm{E}$. Note dark, rounded cores and euhedral, finely zoned rims of grains. 
mainly during the Cretaceous and early Tertiary (Tempelman-Kluit, 1976; Dover, 1985; Gabrielse, 1985). Thus, the most likely source for the Fossil Creek Volcanics may be to the southeast, in or near the Selwyn basin of the Yukon (including the Cassiar and MacKenzie platforms) where strata of similar lithology and age occur (Thompson and Roots, 1982; Tempelman-Kluit, 1984).

The combined Ordovician faunal assemblages, sedimentary facies, and alkalic composition of the basalts in the Fossil Creek Volcanics suggested to Wheeler and others (1987) a shallow-marine depositional environment along a continental margin. A possible model for the deposition of the alkalic basalt and its associated sedimentary rocks of the Fossil Creek Volcanics is in an extensional environment. Although various scenarios are possible, we favor a tectonic setting involving filling of a submarine channel or graben with mafic flows and volcaniclastic debris from volcanic edifices together with minor clasts derived from underlying basement rocks including granite and quartzite. Our presumption, based on the coarse size, clast composition, and stratigraphic occurrence, is that Late Proterozoic to Cambrian granite was eroded from a very local source during deposition of the Fossil Creek Volcanics and that the site of deposition of the Fossil Creek Volcanics was probably within the continent or near its margin. Unfortunately, the likely source area across the Tintina fault in the Yukon is now occupied by a thick Paleozoic platform-basin transitional section. As yet, no Late Proterozoic to Early Cambrian granite basement, or clasts derived from such a granite, are known beneath the Selwyn basin or in adjacent platformal areas such as the Cassiar and MacKenzie platforms. The granite basement is either buried under Paleozoic cover, is completely eroded, or was located elsewhere. In the absence of evidence from elsewhere, the Selwyn basin sequence is still considered to be the most likely correlative to the strata in the White Mountains terrane, based on stratigraphic correlations of Tempelman-Kluit (1984) and Wheeler and others (1987). Gehrels and others (1987) and Gehrels (in press) reported Cambrian U-Pb zircon ages on orthogneisses from the southern end of Gravina, Dall, and Long Islands in the Alexander terrane of southeasternmost Alaska. The possible relationship between these orthogneisses with the granite samples we dated from the White Mountains terrane is unknown. However, the two suites

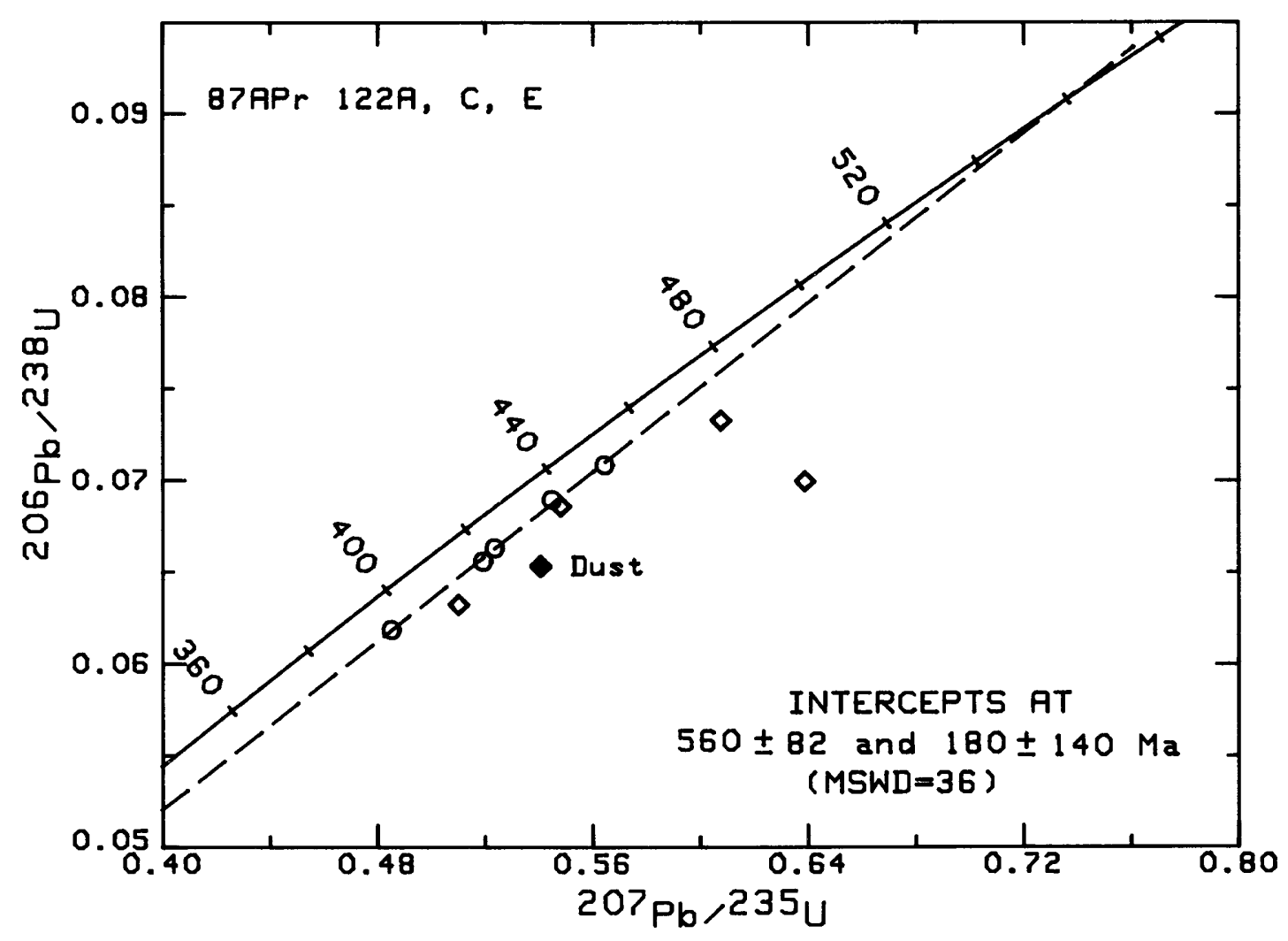

Figure 5. Concordia plot of lead-uranium data in zircons from boulder samples 87APr 122A, C, and E collected from conglomerate layer within the Fossil Creek Volcanics (fig. 3). Regression is calculated through five data points from fine-grained size fractions, shown as circles. Coarse-grained fractions (plotted as diamonds) are not included in regression because these zircons likely contain inherited radiogenic lead. Filled diamond, labeled Dust, is material collected from abrasion of coarse grains. Sample data listed in table 1. 
are the only known Cambrian metaplutonic rocks in Alaska. The location of the provenance for the pink granite boulders with the Fossil Creek Volcanics described in this paper remains an enigma.

\section{ACKNOWLEDGMENTS}

We thank Florence Weber and Karen Wheeler for bringing to the attention of Plafker the granite clasts in conglomerate of the Fossil Creek Volcanics. Mineral separations and elemental extractions were carefully carried out by Marianne Walter.

\section{REFERENCES CITED}

Blodgett, R.B., Wheeler, K.L., Rohr, D.M., Harris, A.G., and Weber, F.R., 1987, A Late Ordovician age reappraisal for the Upper Fossil Creek Volcanics, and possible significance for glacio-eustasy: in Hamilton, T.D. and Galloway, J.P., eds., Geologic studies in Alaska by the U. S. Geological Survey during 1986: U. S. Geological Survey Circular 998, p. 54-58.

Chapman, R.M., Weber, F.R., and Taber, Bond, 1971, Preliminary geologic map of the Livengood quadrangle, Alaska: U. S. Geological Survey Open-File Report 71-66, scale 1:250,000, 2 sheets.

Churkin, Michael, Foster, H.L., Chapman, R.M., and Weber, F.R., 1982, Terranes and suture zones in east central Alaska: Journal of Geophysical Research, v. 87, p. 3718-3730.

Dover, J.H., 1985, Dispersion of Tintina fault displacement in interior Alaska: Geological Society of America Abstracts with Programs, v. 17, p. 352.

Gabrielse, H., 1985, Major dextral transcurrent displacements along the Northern Rocky Mountain Trench and related lineaments in north-central British Columbia: Geological Society of America Bulletin, v. 96, p. 1-14.

Gehrels, G.E., Saleeby, J.B., and Berg, H.C., 1987, Geology of Annette, Gravina, and Duke islands, southeastern Alaska: Canadian Journal of Earth Sciences, v. 24, p. 866-881.

Jones, D.L., Silberling, N.J., Berg, H.C., and Plafker, George, 1981, Preliminary terrane map of Alaska: U. S. Geological Survey Open-File Map 81-792.

Jones, D.L., Silberling, N.J., and Coney, P.J., 1986, Collision tectonics in the Cordillera of western North America: Examples from Alaska, in Coward, M.P., and Ries, A.C., eds., Collision tectonics: Geological Society of London Special Publication 19, p. 367-387.

Jones, D.L., Silberling, N.J., Coney, P.J., and Plafker, George, 1984, Lithotectonic terrane map of Alaska (west of the 141st meridian), in Silberling, N.J., and Jones, D.L., eds., Lithotectonic terrane maps of the North American cordillera: U. S. Geological Survey Open-File Report 84-523.
1987, Lithotectonic terrane map of Alaska (west of 141st meridian): U.S. Geological Survey Miscellaneous Field Studies Map MF-1874-A, scale 1:2,500,000.

Krogh, T.E., 1973, A low-contamination method for hydrothermal decomposition of zircon and extraction of $\mathrm{U}$ and $\mathrm{Pb}$ for isotopic age determinations: Geochimica et Cosmochimica Acta, v. 37, p. 485-494.

Ludwig, K.R., 1980, Calculation of uncertainties of U-Pb isotopic data: Earth and Planetary Science Letters, v. 46, p. 212-220.

1987, ISOPLOT VERSION 2-A plotting and regression program for isotope geochemists, for use with HP Series 200/300 computers: U.S. Geological Survey OpenFile Report 87-601, 59 p.

Mertie, J.B., 1937, The Yukon-Tanana Region, Alaska: U.S. Geological Survey Bulletin 872, 276 p.

Pessel, G.H., Reifenstuhl, R.R., and Albanese, M.D., 1987, Regional Geology, in Smith, T.E., Pessel, G.H., and Wiltse, M.A., eds., Mineral assessment of the Lime Peak-Mt. Prindle area, Alaska: Fairbanks, Alaska, Department of Natural Resources, Division of Geological and Geophysical Surveys, p. 2-1 to 2-26.

Stacey, J.S., and Kramers, J.D., 1975 Approximation of terrestrial lead isotope evolution by a two-stage model: Earth and Planetary Science Letters, v. 26, p. 207-226.

Steiger, R.H., and Jäger, E., 1977, Subcommission on geochronology, convention on the use of decay constants in geoand cosmochronology: Earth and Planetary Science Letters, v. 36 , p. 359-362.

Tempelman-Kluit, D.J., 1976, The Yukon crystalline terrane: Enigma in the Canadian Cordillera: Geological Society of America Bulletin, v. 87, p. 1343-1357.

1984, Counterparts of Alaska's terranes in Yukon, in Symposium of Cordilleran geology and mineral exploration; Status and future trends: Vancouver, Geological Association of Canada, p. 41-44.

Thompson, R.I., and Roots, C.F., 1982, Ogilvie Mountains Project, Yukon, Part A: A new regional mapping program: Geological Survey of Canada, Current Research, Part A, Paper 82-1A, p. 403-411.

Weber, F.R., McCammon, R.B., Rinehart, C.D., and Light, T.D., 1988, Mineral resources of the White Mountains National Recreation Area, east-central Alaska: U.S. Geological Survey Open-File Report 88-284, 187 p.

Weber, F.R., Smith, T.E., Hall, M.C., and Forbes, R.B., 1985, Geologic guide to the Fairbanks-Livengood area, eastcentral Alaska: Anchorage, Alaska Geological Society, $44 \mathrm{p}$.

Wheeler, K.L., Forbes, R.B., Weber, F.R., and Rinehart, C.D., 1987, Lithostratigraphy, petrology, and geochemistry of the Ordovician Fossil Creek Volcanics, east-central Alaska: in Hamilton, T.D. and Galloway, J.P., eds., Geologic studies in Alaska by the U. S. Geological Survey during 1986: U. S. Geological Survey Circular 998 , p. $70-73$.

\section{Reviewers:}

Marvin A. Lanphere

Warren J. Nokleberg 


\title{
Age of Deposition and Provenance of the Cleary Sequence of the Fairbanks Schist Unit, Yukon-Tanana Terrane, East-Central Alaska
}

\author{
By John N. Aleinikoff and Warren J. Nokleberg
}

\begin{abstract}
The Cleary sequence, composed of metasedimentary and felsic metavolcanic rocks, is a member of the informally named Fairbanks schist unit. Prior to this study, the age of the Fairbanks schist unit was thought by some workers to be Late Proterozoic to early Paleozoic, based on interpretations that the Upper Proterozoic to Lower Cambrian informally named Wickersham unit (of the Wickersham terrane) conformably overlies the Fairbanks schist unit. U-Pb geochronology of medium- and fine-grained fractions of euhedral zircon from metarhyolite interpreted as a flow or tuff from the Cleary sequence yields an age of $369 \pm 3 \mathrm{Ma}$. Data from coarse zircons indicate that they contain a small amount of inherited material. Two populations of detrital zircon obtained from metasiltstone from the Cleary sequence have isotopic systematics that indicate an Early Proterozoic provenance (about 2.1 to 2.3 Ga). The Late Devonian age of volcanism in the Fairbanks area is comparable to other dated metavolcanic rocks in the Yukon-Tanana terrane, and the Early Proterozoic provenance age of the detrital zircons agrees with ages of other detrital suites from the Yukon-Tanana terrane.
\end{abstract}

\section{INTRODUCTION}

The Cleary sequence occurs within the informally named Fairbanks schist unit, which forms a major part of the northern Yukon-Tanana terrane in east-central Alaska (fig. 1; Foster and others, 1987). Terrane names in this study are after Jones and others (1987). In and adjacent to Fairbanks, the Cleary sequence consists mainly of a 120- to 240-m-thick sequence of felsic schist, laminated white micaceous quartzite, chlorite-actinolite greenstone, graphitic schist, minor metavolcanic rocks, mainly metarhyolite tuff and flows, calc-schist, and marble (Bundtzen, 1982; Metz, 1982; Robinson, 1982). The Cleary sequence is intensely deformed. A geologic map (fig. 2) shows the sequence occurring in a series of major folds with axial planes that strike east-northeast and dip gently north-northwest or south-southeast (Buntzen, 1982; Metz, 1982; Robinson, 1982). In outcrop and in thin section, the Cleary sequence exhibits a strong schis- tosity and parallel compositional layering which are refolded into minor folds that parallel the major folds. The Cleary sequence occurs within the Fairbanks schist unit, which consists mainly of quartzite and muscovite-quartz schist (Bundtzen, 1982; Metz, 1982; Robinson, 1982). Both the Cleary sequence and Fairbanks schist unit exhibit greenschist-facies metamorphism. The diagnostic metamorphic minerals are chlorite, white mica, biotite, actinolite, albite, and garnet. The Cleary sequence hosts most of the lode $\mathrm{Cu}, \mathrm{Au}$, and $\mathrm{W}$ deposits in the Fairbanks mining district and occurs upstream from the major placer gold deposits in the district (Smith and others, 1981; Nokleberg and others, 1988).

Prior to this study, the age of the Fairbanks schist unit was interpreted as Late Proterozoic or Early Cambrian because, along its northern margin, the Fairbanks schist unit is overlain by the Upper Proterozoic or Lower Cambrian informally named Wickersham unit. This contact is gently north-dipping, and it is interpreted as a depositional contact (Chapman and others, 1971; Weber and others, 1985, 1988). The Wickersham unit is a small unit of continental affinity of which the lower part consists primarily of slate, quartzose sandstone, and granule to pebble conglomerate (Chapman and others, 1971; Weber and others, 1985; Moore and Nokleberg, 1988). The age of the Wickersham unit is based on sparse occurrences of the trace fossil Oldhamia near the top of the lower part of the unit (Chapman and others, 1971). The Wickersham unit was interpreted as the Beaver terrane by Churkin and others (1982) and was renamed as the Wickersham terrane by Jones and others (1987).

Previous workers have interpreted the nature of the contact between the Fairbanks schist unit and the Wickersham unit as either a depositional contact or a fault. A cleavage that intensifies to the south in the Wickersham unit and general similarity in composition between the two units led Chapman and others (1971), Weber and others (1985, 1988), Pessel and others (1987), and Smith and others (1981) to conclude that the Wickersham unit stratigraphically overlies the Fairbanks schist unit. In contrast, Churkin and others (1982), Laird 
and Foster (1984), and Foster and others $(1983,1987)$ interpret the contact as a thrust fault along which the Fairbanks schist unit was emplaced against the Wickersham terrane. Because of these divergent interpretations, we collected samples for isotopic studies of the Cleary sequence during the 1987 field season of the TransAlaskan Crustal Transect (TACT) geologic studies project. The purpose of the sampling was to determine the age of the interlayered and presumably coeval metasedimentary rocks of the Fairbanks schist unit. Such age information is important for interpreting the regional geology and deep crustal structure and is also important for regional metallogenetic studies.

\section{SAMPLE DESCRIPTIONS AND U-Pb GEOCHRONOLOGY}

Two samples of leucocratic, fine-grained, strongly schistose rocks were collected from the Cleary sequence for $\mathrm{U}-\mathrm{Pb}$ geochronology (table 1 ), in conjunction with geologic investigations by T.E. Smith and R.B. Forbes (Alaska Division of Geological and Geophysical Surveys). Field observations, including composition and texture, suggested a volcanic protolith (T.E. Smith, oral commun., 1987). However, thin section examination revealed that only one sample, $87 \mathrm{ANK} 081 \mathrm{~A}$, is a metarhyolite; sample 87ANK078R is a metasiltstone. Zircons were extracted from both samples to determine the igneous age of the metarhyolite sample and the provenance age of the sediments in the metasiltstone sample.

The metarhyolite was collected north of Fairbanks (fig. 2) on a residential road leading north from Farmers Loop Road in the Fairbanks D-2 15-minute quadrangle. The sample is a strongly foliated, medium- to finegrained white metavolcanic schist that forms a small outcrop about $1 \mathrm{~m}$ thick and is surrounded by extensive and thick glacial loess. Detailed mapping and interpretation by Bundtzen (1982) shows this outcrop to consist mainly of metarhyolite, muscovite-quartz schist, and muscovite-quartz-feldspar schist (map units $r$, mqs, and $\mathrm{mrt}$ ) derived from rhyolite flows or tuff, pelitic sediments, and siliceous exhalite, respectively. Schistosity and compositional layering strike northeast and dip moderately northwest. In thin section, the sample is composed primarily of K-feldspar and muscovite, subordinate plagioclase, and accessory zircon and opaque minerals, mostly hematite. Laminae of medium-grained strained quartz and feldspar are separated by very fine grained

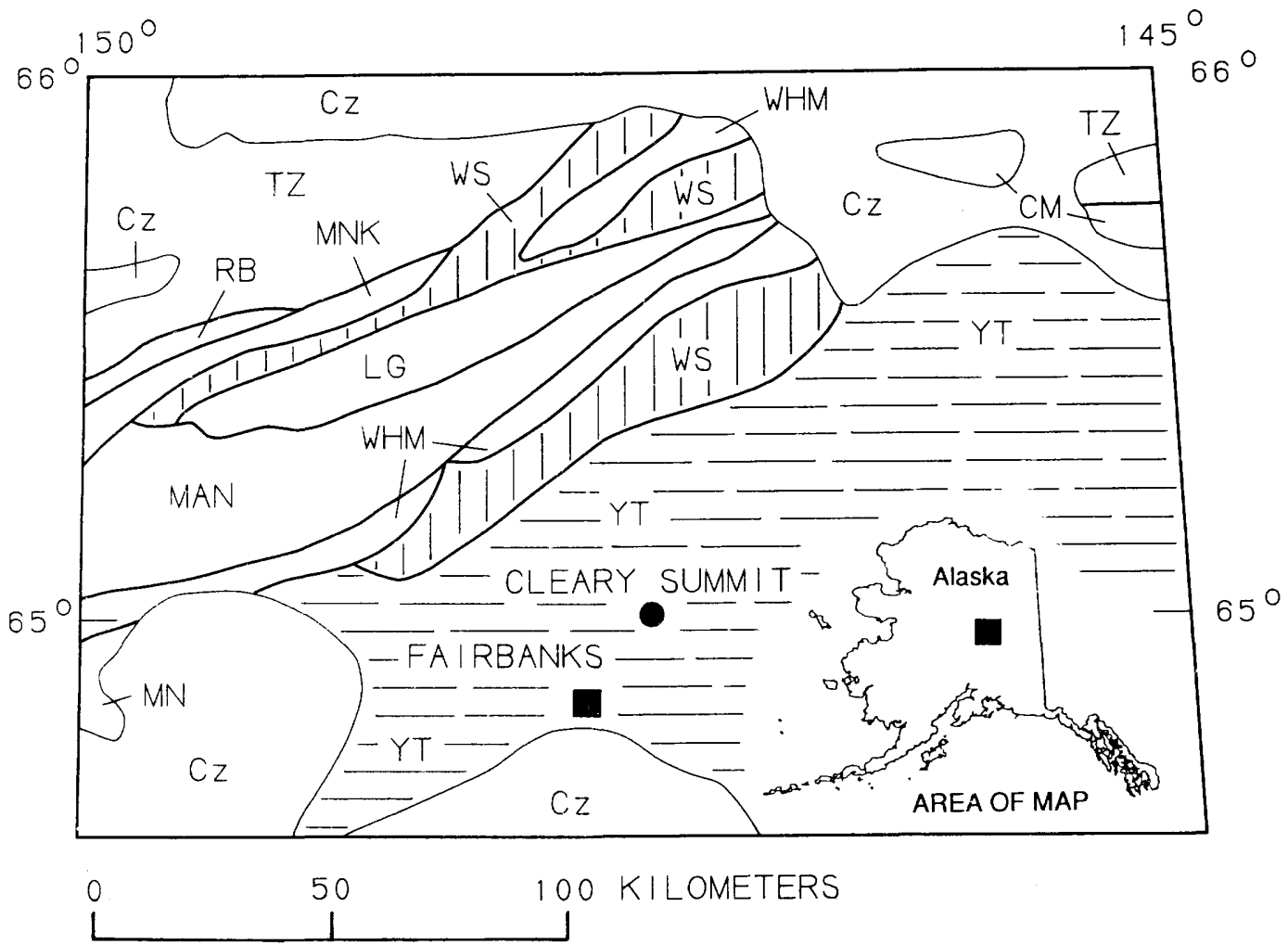

Figure 1. Lithotectonic terranes of east-central Alaska. Abbreviations: $\mathrm{CM}$, Crazy Mountains terrane; LG, Livengood terrane; MAN, Manley terrane; MN, Minchumina(?) terrane; MNK, Minook terrane; RB, Ruby terrane; TZ, Tozitna terrane; WHM, White Mountains terrane; WS, Wickersham terrane; YT, Yukon-Tanana terrane; $\mathrm{Cz}$, Cenozoic basin deposits. Adapted from Jones and others (1987) and Moore and Nokleberg (1988). 
strongly schistose layers of quartz and white mica. The coarser quartz and feldspar grains exhibit suture boundaries and undulatory extinction. Highly altered quartz and feldspar megacrysts, up to $2 \mathrm{~mm}$ long, deflect the schistosity and are interpreted as relict microphenocrysts. The rock is highly fractured and pervasively stained with hematite, which caused difficulty in obtaining a fresh sample. The composition and relict igneous texture sug- gest a rhyolite protolith, either a flow, tuff, or sill. The conformable nature of the Cleary with the Fairbanks schist unit indicates that the Cleary sequence represents a former stratigraphic sequence of pelitic sedimentary rocks, quartzite, rhyolite flows or tuffs, and siliceous exhalite interlayered and deposited with the sedimentary rocks of the Fairbanks schist unit (Bundtzen, 1982; Nokleberg and others, 1988).
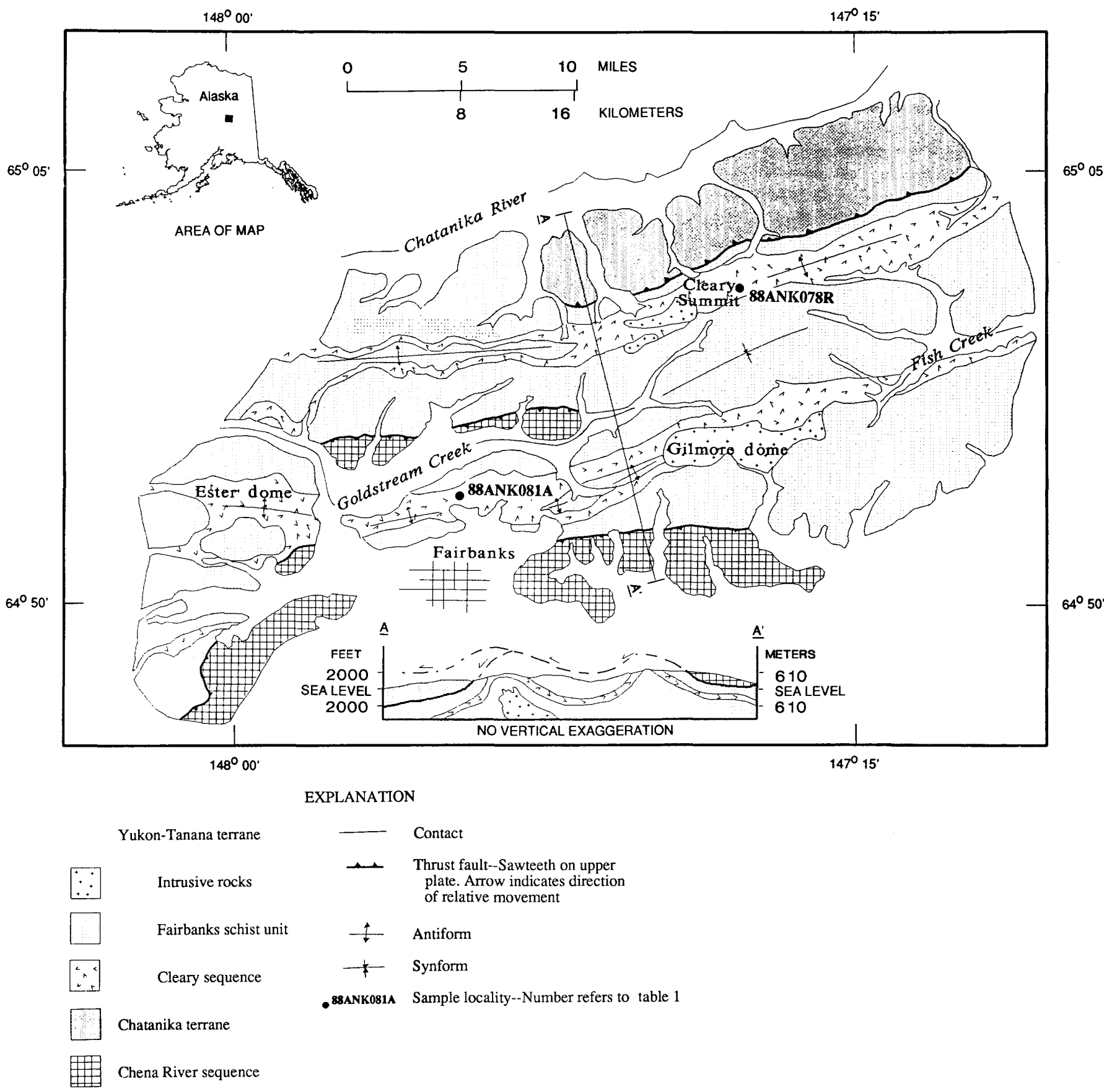

Figure 2. Generalized geologic map of Fairbanks region, northern Yukon-Tanana terrane,southeast Livengood and northeast Fairbanks 1:250,000-scale quadrangles, east-central Alaska. Map shows distribution of the Cleary sequence in isoclinal folds that are refolded along anticlinal ridge crests. Chatanika terrane and Chena River sequence (medium-grade metasedimentary rocks) locally structurally overlie the Fairbanks schist unit (informal usage). Adapted from Bundtzen (1982), Metz (1982), Robinson (1982), and Nokleberg and others (1988). 
Table 1. U-Pb composition and concentration data for zircon from the Cleary sequence of the Fairbanks schist unit, Alaska

\begin{tabular}{|c|c|c|c|c|c|c|c|c|c|c|c|c|}
\hline \multirow{3}{*}{ Fraction' } & \multirow{3}{*}{$\begin{array}{c}\text { Weight } \\
\text { (mg) }\end{array}$} & \multirow{2}{*}{\multicolumn{2}{|c|}{$\begin{array}{c}\text { Concentration } \\
\text { (ppm) }\end{array}$}} & \multicolumn{3}{|c|}{$\mathrm{Pb}$ composition ${ }^{2}$} & \multicolumn{3}{|c|}{ Ratios (percent error) ${ }^{3}$} & \multicolumn{3}{|c|}{ Ages $(\mathrm{Ma})^{4}$} \\
\hline & & & & ${ }^{206} \mathrm{~Pb}$ & ${ }^{206} \mathrm{~Pb}$ & ${ }^{206} \mathrm{~Pb}$ & ${ }^{206} \mathrm{~Pb}$ & ${ }^{207} \mathrm{~Pb}$ & ${ }^{207} \mathrm{~Pb}$ & ${ }^{206} \mathrm{~Pb}$ & ${ }^{207} \mathrm{~Pb}$ & ${ }^{207} \mathrm{~Pb}$ \\
\hline & & $U$ & $\mathrm{~Pb}$ & $\overline{204 \mathrm{~Pb}}$ & $\overline{207 \mathrm{~Pb}}$ & $\overline{208 \mathrm{~Pb}}$ & $\overline{238 \mathrm{U}}$ & $\overline{235 \mathrm{U}}$ & $\overline{206 \mathrm{~Pb}}$ & ${ }^{238} \mathrm{U}$ & $\overline{235 \mathrm{U}}$ & ${ }^{206} \mathrm{~Pb}$ \\
\hline
\end{tabular}

87ANK 081A (metarhyolite-64'54'40", 147'46'33")

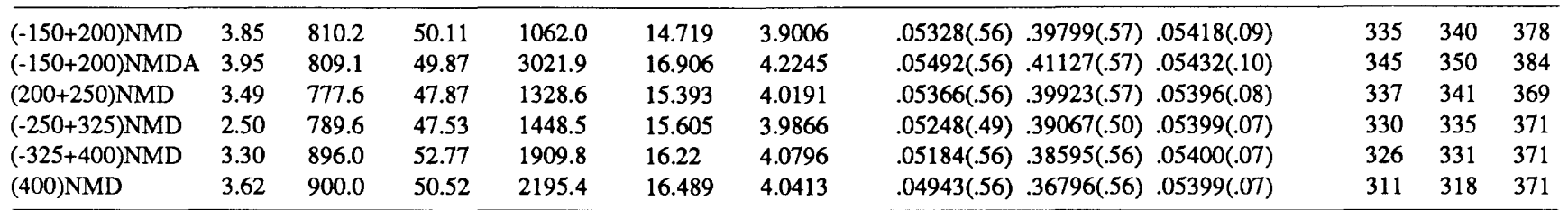

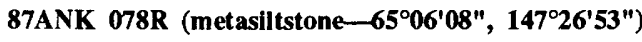

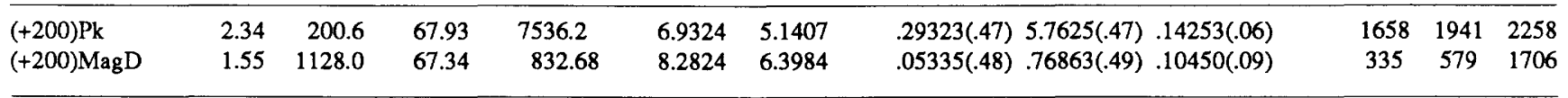

${ }^{1}$ Abbreviations: NM (non-magnetic), D (diamagnetic), A (abraded), Pk (light pink), Mag (magnetic).

${ }^{2}$ Corrected for $1 \mathrm{ng}$ blank and mass fractionation of $0.14 \pm .05$ percent/atomic mass unit.

$32 \sigma$ errors.

${ }^{4}$ Common lead corrected for using appropriate values from Stacey and Kramers (1975). Constants: ${ }^{235} \lambda=9.8485 \mathrm{E}-10 / \mathrm{yr} ;{ }^{238} \lambda=1.55125 \mathrm{E}-10 /$ $\mathrm{yr},{ }^{238} \mathrm{U} /{ }^{235} \mathrm{U}=137.88$ (Steiger and Jäger, 1977).

Previous workers (Bundtzen, 1982; Metz, 1982; Robinson, 1982; Nokleberg and others, 1988) have mapped and interpreted the metaigneous rocks of the Cleary sequence as metamorphosed flows and tuffs. Although poorly exposed and surrounded by extensive loess, we also interpret the metarhyolite sample as a flow or tuff for several reasons: (1) The outcrop occurs within the center of the Cleary sequence, which is mapped and interpreted by Bundtzen (1982) as being derived from rhyolite flows or tuff, pelitic sedimentary rocks, and siliceous exhalite. (2) Metamorphosed sills and dikes are not observed in the adjacent Fairbanks schist unit (Bundtzen, 1982; Metz, 1982; Robinson, 1982). (3) Metarhyolite, pelitic and quartz schist, and metamorphosed exhalite occur only in the Cleary sequence and not in adjacent quartz-rich metasedimentary rocks that compose the bulk of the Fairbanks subterrane. Although less likely, the metarhyolite may be a metamorphosed sill that was the igneous source for flows or tuffs.

The metasiltstone sample was collected northeast of Fairbanks a few hundred meters north of Cleary Summit on the west side of the Steese Highway in the Livengood A-1 15-minute quadrangle (fig. 2). The sample is a strongly foliated, medium-grained, iron-stained metasedimentary schist that was collected from a steep hillside in a layer up to a few meters thick within the Fairbanks schist unit. Detailed mapping and interpretation by Metz (1982) show this outcrop to consist mainly of quartzite, muscovite-quartz schist, greenstone, and muscovite-quartz-feldspar schist (map units q, mqs, ca, and $\mathrm{mrt}$ ) derived from quartzite, pelitic sediments, mafic tuff, and siliceous exhalite, respectively. Schistosity and compositional layering strike north-northeast and dip gently east-southeast. In thin section, the sample is composed primarily of quartz, with thin layers of white mica. The quartz grains are fairly equigranular and exhibit a mosaic texture. The white mica grains are strongly aligned parallel to a strong schistosity. The sample also contains flattened fragments of fine-grained quartz cemented by hematite. Zircon occurs in the white mica-rich layers. This sample is also strongly ironstained, although a reasonably fresh sample was obtained. The quartz-rich composition and fine-grained texture suggest a siliceous siltstone protolith.

Zircons from the metarhyolite are light brown to clear and most are euhedral (about half are doubly terminated). The length/width ratio $(\mathrm{l} / \mathrm{w})$ ranges from $1 / 1$ to $3 / 1$. The grains exhibit fine euhedral zoning, and many contain opaque inclusions. In the coarser populations, some zircons contain dark, rounded, partially resorbed (inherited?) cores (fig. 3). The finer populations are generally core-free. This zircon morphology suggests an igneous origin. All crystal faces are somewhat pitted, suggesting postcrystallization (metamorphic) damage. No grains were observed that had obvious detrital characteristics, such as rounding, pitting, or frosting. Thus, dating these zircons should determine the age of the igneous protolith of the metarhyolite. However, as discussed below, cores in coarser grains complicate the isotopic systematics.

The zircons from the metasiltstone form two populations based on color (very dark brown and shades of pink) and they range in shape from round to oblong ( $1 / \mathrm{w}$ of $1 / 1$ to $3 / 1$ ). All grains are frosted and abraded, 
indicating a detrital origin for the rock. Dating these zircons should provide information about the provenance age of the sediments, but will not date the age of sedimentation.

Six size fractions of zircon from metarhyolite were analyzed for $\mathrm{Pb}$ isotopic compositions and $\mathrm{U}$ and $\mathrm{Pb}$ concentrations (table 1). Analytical procedures are slightly modified from the methods of Krogh (1973), as outlined in Aleinikoff and others (1986). Isotopic ratios were measured on a VG 54E automated mass spectrometer. Uncertainties in $\mathrm{Pb} / \mathrm{U}$ ratios range from 0.47 to 0.56 percent $(2 \sigma)$; uncertainties in ${ }^{207} \mathrm{~Pb} /{ }^{206} \mathrm{~Pb}$ range from 0.06 to 0.10 percent $(2 \sigma)$ (table 1$)$. Age calculations and concordia plots use programs of Ludwig $(1980,1987)$.

Uranium concentrations are moderate (about 775 to $900 \mathrm{ppm})$. The four fine fractions ( $<150 \mathrm{mesh})$ have ${ }^{207} \mathrm{~Pb} /{ }^{206} \mathrm{~Pb}$ ages of $369-371 \mathrm{Ma}$ and $\mathrm{Pb} / \mathrm{U}$ ages of

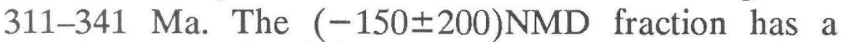
slightly older ${ }^{207} \mathrm{~Pb} /{ }^{206} \mathrm{~Pb}$ age of $378 \mathrm{Ma}$. We attribute this older age to the presence of inherited cores in the coarsest zircons, as seen in immersion mount microscopic examination (fig. 3). Additional evidence for inherited radiogenic lead is that a split composed of cores (fraction ( $-150 \pm 200)$ NMDA, table 1), derived from abrasion of the coarse fraction, has a slightly older ${ }^{207} \mathrm{~Pb} /{ }^{206} \mathrm{~Pb}$ age of $384 \mathrm{Ma}$. Because the coarsest zircons contain inherited radiogenic lead, a best-fit line is calculated through only the four finer fractions that are core-free. This regression has concordia intercept ages of $369 \pm 3$ and $-10 \pm 27 \mathrm{Ma}$ (fig. 4). We interpret the data as indicating a Late Devonian age of crystallization for the metarhyolite protolith. Although the coarse zircons contain inheritance, the measured systematics do not permit calculation of the age of inheritance. However, based on other studies in the Yukon-Tanana terrane (Aleinikoff and others, 1986), a likely age for the older core material is about 2.1-2.3 Ga. The calculated discordia has a present-day lower intercept age, suggesting that postcrystallization events, such as Cretaceous metamorphism and Tertiary granite intrusion (Wilson and others, 1985; Nokleberg and others, 1986, Hansen and others, 1988), did not significantly disturb the U-Pb systematics in these zircons.

Two splits of zircons were hand-picked from the heterogeneous population extracted from the metasiltstone. These fractions are composed of zircons that are (1) relatively nonmagnetic, light pink, and round and (2) zircons that are magnetic, dark brown, and round. The ${ }^{207} \mathrm{~Pb} /{ }^{206} \mathrm{~Pb}$ ages for these fractions are 2,258 and 1,706 $\mathrm{Ma}$, respectively (table 1). $\mathrm{Pb} / \mathrm{U}$ ages of 1,658 and 1,941 $\mathrm{Ma}$ (pink zircons) and 335 and $579 \mathrm{Ma}$ (dark-brown zircons), representing discordance of 25 percent and 80 percent, respectively, are directly related to uranium content. The somewhat discordant pink zircons contain $201 \mathrm{ppm} \mathrm{U}$, whereas the very discordant dark-brown zircons contain $1,128 \mathrm{ppm}$ U. Thus, greater metamicti-

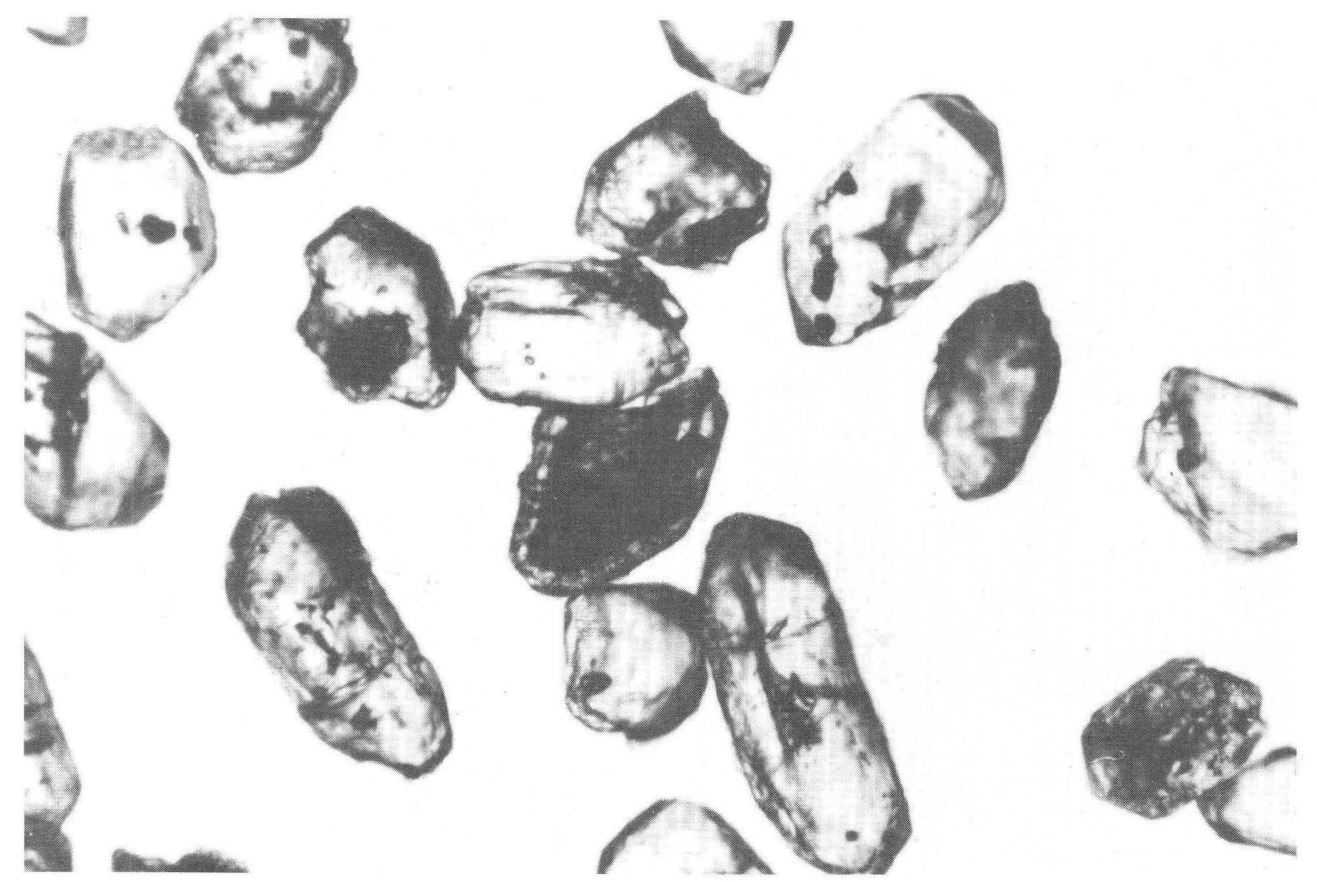

Figure 3. Photomicrograph of zircons from sample 87ANK 081A, fraction $(-150 \pm 200) \mathrm{NMD}$ (table 1). Largest grains are about $150 \mu \mathrm{m}$ in length. Note distinct, rounded, dark cores and clear overgrowths on grains. 
zation in the dark-brown zircons, due to about six times higher uranium concentration, allowed significantly more lead loss than in the pink zircons.

Concordia plots of detrital zircon data generally are not useful because the selected populations may be neither cogenetic nor contemporaneous. However, data compiled from five other metasedimentary rocks ( 10 data points) from the Yukon-Tanana terrane (Mount Hayes, Big Delta, and Circle 1:250,000-scale quadrangles; Aleinikoff and others, 1984; 1986) reveal that the two new data points from the metasiltstone plot within a band of previously determined results (fig. 5). A sample of dark magnetic zircon from a quartzite in the Big Delta quadrangle (Aleinikoff and others, 1986) has uranium contents and U-Pb systematics very similar to the magnetic fraction from the metasiltstone. Other fractions of lighter colored, relatively nonmagnetic zircons with much lower uranium contents, including the pink fraction from the metasiltstone, form a colinear band on a concordia plot (fig. 5). Because of scatter and because these are widely separated metasedimentary samples with heterogeneous populations of zircon, a reference chord (applicable to the nonmagnetic, lower uranium fractions), rather than a calculated best-fit regression with intercepts of about 370 and 2,250 Ma, is plotted. Scatter about this chord may be due to a number of causes, such as variation in the ages of the protolith and multiple periods of lead loss, including both thermal/ metamorphic events and modern dilatancy during erosion and uplift.

\section{DISCUSSION AND INTERPRETATIONS}

The above isotopic data are significant for several reasons. First, the isotopic data show that at least a part of the Cleary sequence and the enclosing Fairbanks schist unit of the northern Yukon-Tanana terrane is Late Devonian. The hypothesis that the Fairbanks schist unit is Precambrian because it formed the lowest structural level in the region is clearly untenable. Second, the Late Devonian age is compatible with the interpretation (Churkin and others, 1982; Foster and others, 1983, 1987) that the northern Yukon-Tanana terrane is thrust against the Wickersham terrane to the north (fig. 1), rather than being depositionally overlain by the Wickersham terrane. And third, the Late Devonian igneous age of the metarhyolite of the Cleary sequence and the Early Proterozoic age of the provenance of zircons in the Cleary sequence provide absolute ages for interpreting

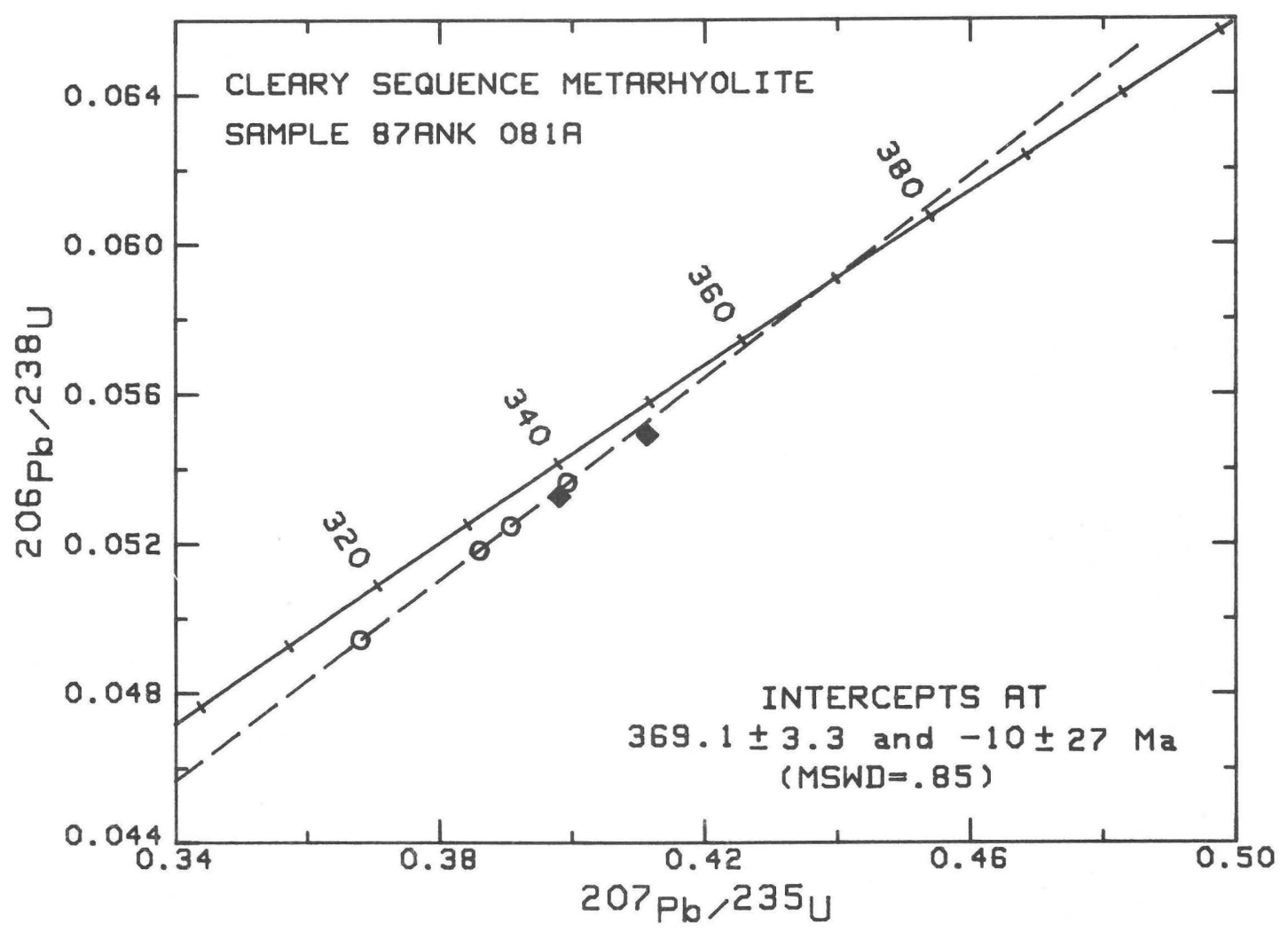

Figure 4. Concordia plot of lead-uranium data from metarhyolite sample 87ANK 081A from the Cleary sequence. Regression of best-fit line is through data from fine-grained size fractions (circles) only. Coarse-grained fractions (solid diamonds) are excluded from regression because those zircons contain small amounts of inherited radiogenic lead. Sample data listed in table 1. 
the regional geology and deep crustal structure of the Yukon-Tanana terrane and for interpreting regional metallogenesis.

The age of the metarhyolite in the Cleary sequence is similar to ages of metavolcanic rocks that occur in thrust sheets in the central and southern parts of the Yukon-Tanana terrane in the Big Delta and Mount Hayes quadrangles (Aleinikoff and Nokleberg, 1985; Aleinikoff and others, 1986; Foster and others, 1987). Additional support for a Devonian age for the Cleary sequence and the surrounding Fairbanks schist unit results from identification of rocks correlated with the Cleary sequence in the Salcha River area about $90 \mathrm{~km}$ to the southeast of Fairbanks in the Big Delta quadrangle. In this area, a thin sequence of metatuff and quartz-mica schist is correlated with the Cleary sequence (J.R. Mitchell, oral commun., 1989). This sequence occurs in the pelitic schist unit that overlies the sillimanite gneiss dome (Dusel-Bacon and Foster, 1983) in the Yukon-Tanana terrane. Two other silicic metavolcanic rocks to the east in the Yukon-Tanana terrane also have Devonian U-Pb zircon ages (Aleinikoff and others, 1986). A sample of white gneiss in the southwestern corner of the Big Delta quadrangle, interpreted as a metatuff, is similar in composition, mineralogy, and texture and has a U-Pb zircon age of $362 \pm 14 \mathrm{Ma}$ (Aleinikoff and others, 1986).
Several felsic metavolcanic rocks in the Jarvis Creek Glacier subterrane of the southern Yukon-Tanana terrane in the northern Mount Hayes quadrangle have $\mathrm{U}-\mathrm{Pb}$ ages of about $375 \mathrm{Ma}$ (Aleinikoff and Nokleberg, 1985; Nokleberg and Aleinikoff, 1985). The metavolcanic and metasedimentary rocks of the Jarvis Creek Glacier subterrane in the upper structural levels of the southern Yukon-Tanana terrane (Nokleberg and Aleinikoff, 1985; Nokleberg and others, 1986) are quite similar in composition, texture, structure, isotopic age, and protolith to those of the Fairbanks schist unit and the Cleary sequence. These similarities suggest that rocks of the Jarvis Creek Glacier subterrane and Fairbanks schist unit may be correlative units. These data also indicate that middle Paleozoic (Devonian to Mississippian) magmatism occurred throughout the Yukon-Tanana terrane.

The source area for detrital zircons in the sedimentary rocks in the Yukon-Tanana terrane, indicating provenance ages of about 2.1-2.3 Ga, remains enigmatic. Detrital zircons from metasedimentary rocks with similar ages have been reported from rocks of the Windermere Supergroup in the Cassiar terrane of southern Yukon and northern British Columbia (Evenchick and others, 1984; Erdmer and Baadsgaard, 1987), on strike with the Yukon-Tanana terrane about $1,100 \mathrm{~km}$ to the southeast. Other evidence for the age of the parent rocks is 2.1- to

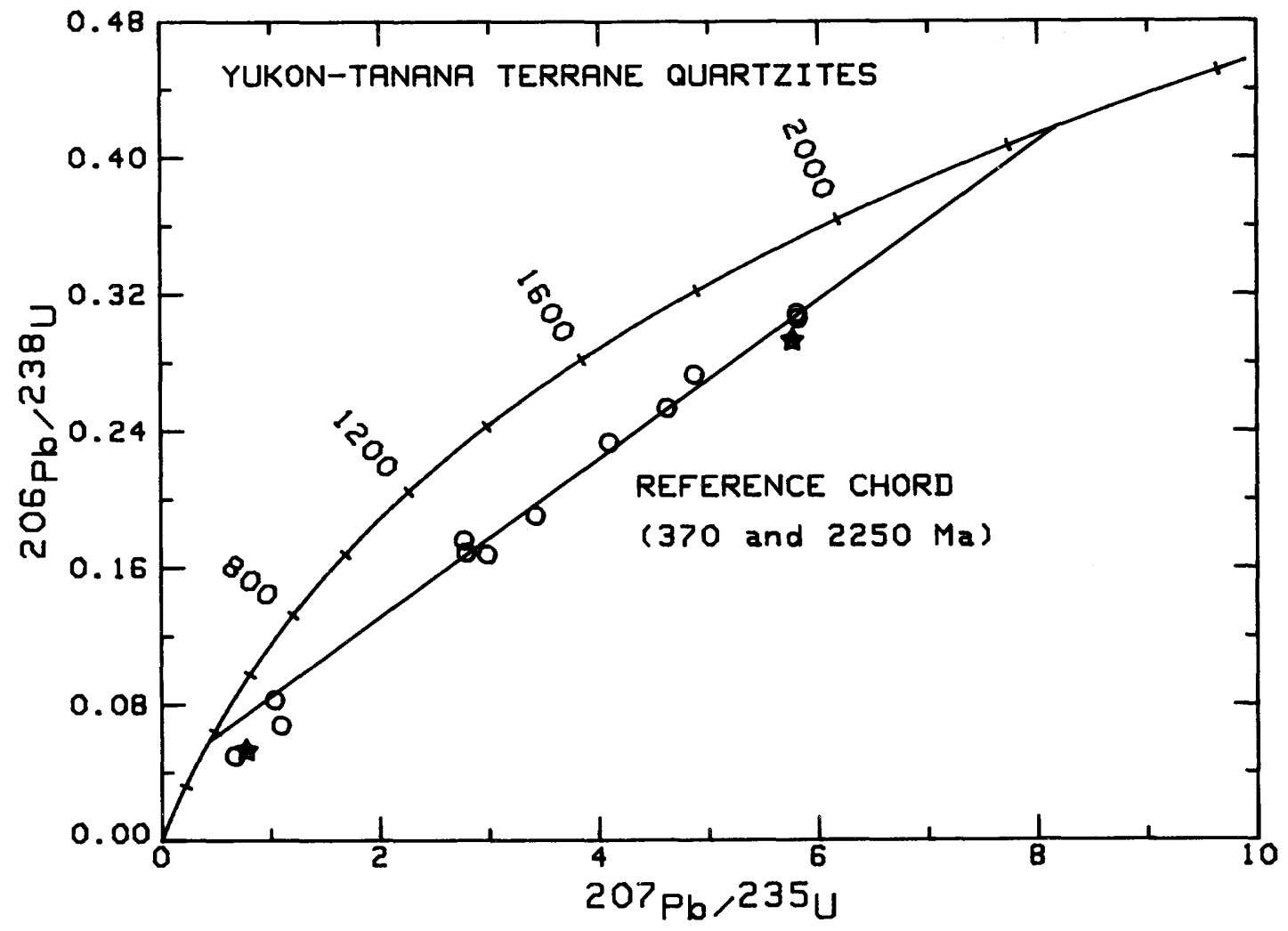

Figure 5. Concordia plot of lead-uranium data from detrital zircons from five quartzite samples in Yukon-Tanana terrane. Data from sample 87ANK 078R plotted as stars. Other samples are Aleinikoff and others $(1984,1986)$. Sample data listed in table 1. 
2.3-Ga U-Pb upper intercept ages (Mortenson and Jilson, 1985; Aleinikoff and others, 1986) and Sm-Nd model ages (Aleinikoff and others, 1981; Bennett and Hansen, 1988) from Devonian to Mississippian orthogneisses of the Yukon-Tanana terrane in Alaska and the Yukon. Although rocks of nearly appropriate age crop out in the Bear-Slave structural province about $1,400 \mathrm{~km}$ to the east-southeast (Frith and others, 1977), a geographically viable source for the detrital zircons in the Yukon-Tanana terrane is still unknown.

\section{ACKNOWLEDGMENTS}

We thank Marianne Walter for careful mineral separations and $\mathrm{U}-\mathrm{Pb}$ chemistry.

\section{REFERENCES CITED}

Aleinikoff, J.N., Dusel-Bacon, Cynthia, and Foster, H.L., 1986, Geochronology of augen gneiss and related rocks, Yukon-Tanana terrane, east-central Alaska: Geological Society of America Bulletin, v. 97, p. 626-637.

Aleinikoff, J.N., Dusel-Bacon, Cynthia, Foster, H.L., and Futa, Kiyoto, 1981, Proterozoic zircon from augen gneiss, Yukon-Tanana Upland, east-central Alaska: Geology, v. 9, p. 469-473.

Aleinikoff, J.N., Dusel-Bacon, Cynthia, Foster, H.L., and Nokleberg, W.J., 1984, Isotopic evidence from detrital zircons for Early Proterozoic crustal material, east-central Alaska, in Coonrad, W.L., and Elliott, R.L., eds., The U.S. Geological Survey in Alaska: Accomplishments during 1981, U.S. Geological Survey Circular 868, p. 43-45.

Aleinikoff, J.N., and Nokleberg, W.J., 1985, Age of Devonian igneous-arc terranes in the northern Mount Hayes quadrangle, eastern Alaska Range, in Bartsch-Winkler, Susan, ed., The U.S. Geological Survey in Alaska: Accomplishments during 1984: v. 20, p. A111.

Bundtzen, T.K., 1982, Bedrock geology of the Fairbanks mining district, western sector: Alaska Division of Geological and Geophysical Surveys Open-File Report AOF-155, 2 sheets, scale 1:24,000.

Chapman, R.M., Weber, F.R., and Taber, Bond, 1971, Preliminary geologic map of the Livengood quadrangle, Alaska: U.S. Geological Survey Open-File Report 483, 2 sheets, scale 1:250,000.

Churkin, Michael, Jr., Foster, H.L., Chapman, R.M., and Weber, F.R., 1982, Terranes and suture zones in eastcentral Alaska: Journal of Geophysical Research, v. 87, p. 3718-3730.

Dusel-Bacon, Cynthia, and Foster, H.L., 1983, A sillimanite gneiss dome in the Yukon-Crystalline terrane, eastcentral Alaska: U.S. Geological Survey Professional Paper 1170-E, $24 \mathrm{p}$.

Erdmer, Philippe, and Baadsgaard, Hafdan, 1987, 2.2 Ga age of zircons in three occurrences of Upper Proterozoic clastic rocks of the northern Cassiar terrane, Yukon and British
Columbia: Canadian Journal of Earth Sciences, v. 24, p. 1919-1924.

Evenchick, C.A, Parrish, R.R., and Gabrielse, Hugh, 1984, Precambrian gneiss and Late Proterozoic sedimentation in north-central British Columbia: Geology, v. 12, p. 233-237.

Foster, H.L., Keith, T.E.C., and Menzie, W.D., 1987, Geology of east-central Alaska: U.S. Geological Survey Open-File Report 87-188, 59 p.

Foster, H.L., Laird, Jo, Keith, T.E.C., Cushing, G.W., and Menzie, W.D., 1983, Preliminary geologic map of the Circle quadrangle, Alaska: U.S. Geological Survey Open-File Report 83-170-A, 29 p., scale 1:250,000.

Frith, Rosaline, Frith, R.A., and Doig, Ronald, 1977, The geochronology of the granitic rocks along the Bear-Slave Structural Province boundary, northwest Canadian Shield: Canadian Journal of Earth Sciences, v. 14, p. 1356-1373.

Hansen, V.L., Heizler, M.T., and Harrison, T.M., 1988, Mesozoic thermal evolution of the Yukon-Tanana terrane, Yukon and Alaska: New evidence from ${ }^{40} \mathrm{Ar} /{ }^{39} \mathrm{Ar}$ data: Geological Society of America Abstracts with Programs, v. 20, p. A111-A112.

Jones, D.L., Silberling, N.J., Coney, P.J., and Plafker, George, 1987, Lithotectonic terrane map of Alaska: U. S. Geological Survey Map MF-1874-A, 1 sheet, scale $1: 2,500,000$.

Krogh, T.E., 1973, A low-contamination method for hydrothermal decomposition of zircon and extraction of $\mathrm{U}$ and $\mathrm{Pb}$ for isotopic age determinations: Geochimica et Cosmochimica Acta, v. 37, p. 485-494.

Laird, Jo, and Foster, H.L., 1984, Description and interpretation of a mylonitic foliated quartzite unit and feldspathic quartz wacke (grit) unit in the Circle quadrangle, Alaska, in Reed, K.M., and Bartsch-Winkler, Susan, eds., The U.S. Geological Survey in Alaska: Accomplishments during 1982: U.S. Geological Survey Circular 939, p. 29-33.

Ludwig, K.R., 1980, Calculation of uncertainties of U-Pb data: Earth and Planetary Science Letters, v. 47, p. 212-220. -1987, ISOPLOT VERSION 2 - A plotting and regression program for isotope geochemists, for use with HP Series 200/300 computers: U.S. Geological Survey OpenFile Report 87-601, 59 p.

Metz, P.A., 1982, Bedrock geology of the Fairbanks mining district, northeast sector: Alaska Division of Geological and Geophysical Surveys Open-File Report AOF-154, 1 sheet, scale 1:24,000.

Moore, T.E., and Nokleberg, W.J., 1988, Stratigraphy, sedimentology, and structure of the Wickersham terrane in the Cache Mountain area, east-central Alaska, in Galloway, J.P., and Hamilton, T.D., eds., Geologic Studies in Alaska by the U.S. Geological Survey during 1987: U.S. Geological Survey Circular 1016, p. 75-80.

Mortensen, J.K., and Jilson, G.A., 1985, Evolution of the Yukon-Tanana terrane: Evidence from southeastern Yukon Territory: Geology, v. 13, p. 806-810.

Nokleberg, W.J., and Aleinikoff, J.N., 1985, Summary of stratigraphy, structure, and metamorphism of Devonian igneous-arc terranes, northeastern Mount Hayes quadrangle, eastern Alaska Range, in Bartsch-Winkler, 
Susan, ed., The U.S. Geological Survey in Alaska: Accomplishments during 1984: U. S. Geological Survey Circular 967, p. 66-71.

Nokleberg, W.J., Aleinikoff, J.N., and Lange, I.M., 1986, Cretaceous deformation and metamorphism in the northeastern Mount Hayes quadrangle, eastern Alaskan Range, in Bartsch-Winkler, Susan, and Reed, K.M., eds., Geologic studies in Alaska by the U.S. Geological Survey during 1985: U.S. Geological Survey Circular 978, p. 64-69.

Nokleberg, W.J., Bundtzen, T.K., Berg, H.C., Brew, D.A., Grybeck, Donald, Robinson, M.S., Smith, T.E., Yeend, Warren, 1988, Metallogeny and major mineral deposits of Alaska: U.S. Geological Survey Open-File Report 88-73, 87 p., 2 sheets, scale 1:5,000,000.

Pessel, G.H., Reifenstuhl, R.R., and Albanese, M.D., 1987, Region geology, in Smith, T.E., Pessel, G.H., and Wiltse, M.A., eds., Mineral assessment of the Lime Peak-Mt. Prindle area, Alaska: Fairbanks, Alaska Department of Natural Resources, Division of Geological and Geophysical Surveys, p. 2-1 to 2-26.

Robinson, M.S., 1982, Bedrock geology of the Fairbanks mining district, southeast sector: Alaska Division of Geological and Geophysical Surveys Open-File Report AOF146, 1 sheet, scale 1:24,000.

Smith, T.E., and Pessel, G.H., 1987, Bedrock geology map of the Lime Peak-Mt. Prindle area, east-central Alaska:
Alaska Division of Geological and Geophysical Surveys, Report of Investigations 87-4, plate 2-1a, scale 1:63,360.

Smith, T.E., Robinson, M.S., Bundtzen, T.K., and Metz, P.A. 1981, Fairbanks mining district in 1981: New look at an old mineral province [abs.]: Alaska Miners Association Convention Program with Abstracts, p. 12.

Steiger, R.H., and Jäger, E., 1977, Subcommission on Geochronology, convention on the use of decay constants in geoand cosmochronology: Earth and Planetary Science Letters, v. 36 , p. $359-362$

Weber, F.R., McCammon, R.B., Rinehart, C.D., Light, T.D., and Wheeler, K.L., 1988, Geology and mineral resources of the White Mountains National Recreation Area, east-central Alaska: U.S. Geological Survey Open-File Report 88-282.

Weber, F.R., Smith, T.E., Hall, M.H., and Forbes, R.B., 1985, Geologic guide to the Fairbanks-Livengood area, eastcentral Alaska: Anchorage, Alaska Geological Society, $44 \mathrm{p}$.

Wilson, F.H., Smith, J.G., and Shew, Nora, 1985, Review of radiometric data from the Yukon Crystalline Terrane, Alaska and Yukon Territory: Canadian Journal of Earth Sciences, v. 22, p. 525-537.

\section{Reviewers:}

Cynthia Dusel-Bacon

Joseph L. Wooden 


\title{
Geologic Setting, Petrology, and Age of Pliocene to Holocene Volcanoes of the Stepovak Bay Area, Western Alaska Peninsula
}

\author{
By Frederic H. Wilson
}

\begin{abstract}
Five volcanoes are situated north of Stepovak Bay on the western Alaska Peninsula; only one of these, Kupreanof volcano, had been reported prior to USGS reconnaissance geologic mapping of the area between 1982 and 1986. The volcanoes overlie sedimentary rocks of Eocene to late Miocene age and welded(?) tuff deposits of uncertain, but presumably late Tertiary, age. All five of the volcanoes are aligned northeast-southwest at the southeast end of the welldefined Chignik segment of the Aleutian arc. The group shows evidence of eruptive activity beginning approximately 4.7 $\mathrm{Ma}$ and continuing into Holocene time and represents one of the longest lived active volcanic centers on the Alaska Peninsula. Associated rocks are generally tholeiitic andesite in composition and have a limited range of mineralogy and texture. Extensive upper Tertiary and Quaternary andesite lava flows cap ridges and fill valleys in the vicinity of the volcanoes and, in some cases, extend to near sea level. Holocene eruptive activity, which occurred on four of the five Stepovak Bay group volcanoes, resulted in three small debris flows, two short lava flows, and a small cinder cone. Active fumaroles exist today on two of the volcanoes.
\end{abstract}

\section{INTRODUCTION}

The Stepovak Bay volcanoes consist of a chain of five relatively closely spaced Quaternary eruptive centers located along the Aleutian arc on the western Alaska Peninsula (figs. 1, 2). Kupreanof volcano, a stratovolcano nearly $1,900 \mathrm{~m}$ high, is the largest and best known of the group (Coats, 1950) and the only volcano of the group that has been formally named (fig. 2). The three southernmost volcanoes were located during reconnaissance geologic mapping in 1982 (Yount and others, 1985). Later work, through 1986, more completely defined these three volcanoes, and an additional center was discovered between these and Kupreanof volcano. For easy reference, the newly discovered centers are informally referred to by number (1-4), starting from the southwest (figs. 1, 2 and table 1).

The volcanoes, other than Kupreanof, were previously undiscovered chiefly because poor weather and limited access tend to prevent close examination of the area. A party from the Harriman Expedition of 1899 (Palache, 1904) stopped in Chichagof Bay southwest of the volcanoes but was limited to short excursions in the vicinity of the bay. Maddren (1919) and Eakins (1970) reported sulfur deposits and a fumarole that has since been determined to be on volcano 4 , but neither author reported the volcanoes as eruptive centers. Burk's (1965) regional map of the Alaska Peninsula shows volcanic rocks in the area, but he did not recognize that these rocks include Quaternary volcanic centers that have had Holocene activity. All of these studies were handicapped by poor access and, until recently, an extremely poor quality topographic base map of the area. The area is remote enough that most rivers, streams, and peaks don't have names, even in local usage. The geologic information presented here is reconnaissance in nature; limited field time and, in particular, difficult access and poor weather continue to handicap studies in the area.

The discovery of these volcanoes is an outgrowth of geologic mapping in support of the Alaska Mineral Resource Assessment Program (AMRAP) studies in the Port Moller, Stepovak Bay, and Simeonof Island 1:250,000-scale quadrangles. M.E. Yount, R.L. Detterman, and J.W. Miller assisted in the mapping of the volcanoes and in discussions on the interpretation of the data; their help is gratefully acknowledged.

\section{GEOLOGIC SETTING}

The Stepovak Bay volcanoes occur at and define the southwest end of a N. $40^{\circ}$ E. oriented linear segment of the generally northeast trending Aleutian volcanic arc, about $280 \mathrm{~km}$ northwest of the Aleutian trench. Here, this segment is informally referred to as the Chignik volcanic arc segment (fig. 1). This segment includes the better known and much larger Mount Veniaminof and Aniakchak Crater volcanoes (Coats, 1950). The Chignik segment is defined by major right-lateral transverse offsets of the Aleutian arc. The offset at the northeast 
end of the Chignik segment lies between Aniakchak and Yantarni volcanoes (Riehle and others, 1987). The southwest end of the Chignik segment lies between volcano 1 of the Stepovak Bay volcanoes and Mount Dana, the next Holocene volcanic center, which is located to the southwest. The intervening region contains small areas of Pleistocene volcanic flows and a Pleistocene dome (fig. 1, U1 and U2).

Three kinds of geologic transitions occur in the vicinity of the Stepovak Bay volcanoes. (1) Aeromagnetic and gravity data from the central Alaska Peninsula suggest that the underlying crust is transitional between oceanic crust of the Aleutian Islands and continental crust of the northeast end of the Alaska Peninsula (Case and others, 1981, 1987). (2) The southwest end of the Chignik segment closely corresponds to the northeastern end of the Shumagin seismic gap (fig. 1; Davies and others, 1981). (3) The southwest end of the Chignik segment also marks a transition in structural style of the Mesozoic and early Tertiary rocks of the Alaska Peninsula. The volcanoes rest in part on northeast-trending folds with generally gentle dips that are locally overturned and overthrust from the northwest (Detterman and others, 1981, 1987). Southwest of the volcanoes, the structural style is fault dominated rather than fold dominated, and thrusting was from the southeast rather than the northwest.

The Stepovak Bay volcanoes overlie sedimentary rocks of Eocene to Pliocene age. All but the southernmost of the volcanoes are built on rocks of the middle and upper Miocene Bear Lake Formation and the Pliocene Milky River Formation. The Bear Lake Formation is a shallow marine sandstone and conglomerate distinctive among Tertiary stratigraphic units on the Alaska
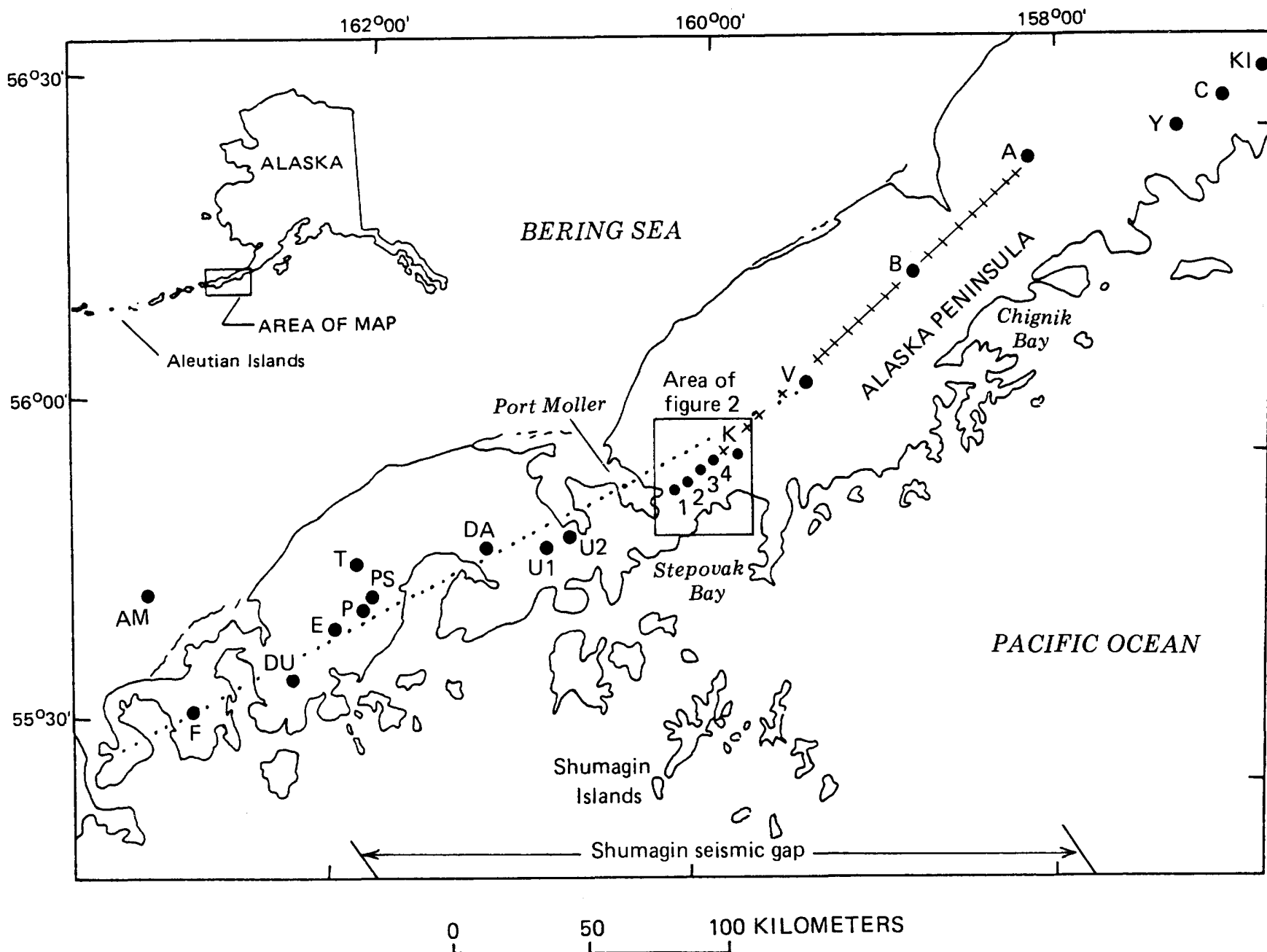

Figure 1. Locations of Quaternary volcanic centers of Aleutian arc on western Alaska Peninsula. Abbreviations: KI, Mount Kialagvik; C, Mount Chiginagak; Y, Yantarni volcano; A, Aniakchak Crater; B, Black Peak; V, Mount Veniaminof; K, Kupreanof volcano; 1-4, unnamed Stepovak Bay volcanoes; U1 and U2, unnamed Quaternary volcanic centers; DA, Mount Dana; T, Trader Mountain; PS, Pavlof Sister; P, Pavlof volcano; E, Emmons Lake; DU, Mount Dutton; F, Frosty Peak; AM, Amak volcano. Dotted line indicates Cold Bay volcanic arc segment of Kay and others (1982), hatched line indicates Chignik volcanic arc segment (see text). 


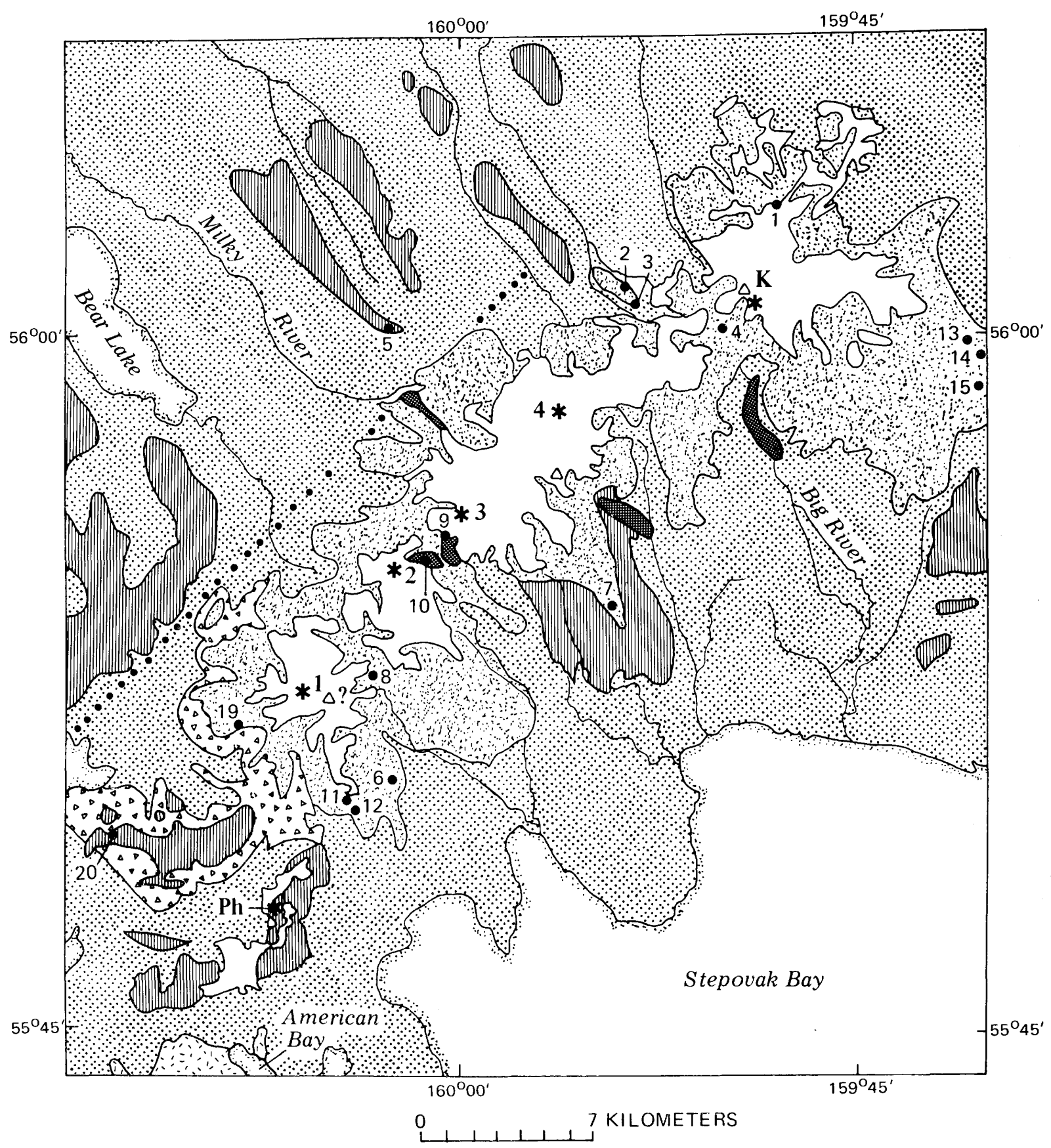

EXPLANATION

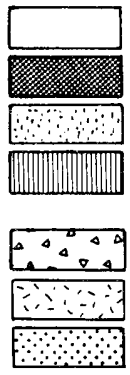

Glaciers

Holocene volcanic flows

Pleistocene volcanic flows

Quaternary (?) and upper Tertiary (?) volcanic flows
* 4 Volcanic center

- 1 Sample locality -- Number refers to table 2

$\triangle \quad$ Fumarole --Queried where uncertain

Upper Tertiary (?) welded (?) tuff

Pliocene quartz diorite

Pliocene and older sedimentary and igneous

rocks and Quaternary surficial deposits

Figure 2. Simplified geologic map showing locations of Stepovak Bay volcanoes. Base map from Port Moller (1953), Stepovak Bay (1963), and Chignik (1963) 1:250,000-scale quadrangles. Volcanic centers shown by asterisks and identified by numbers except $\mathrm{K}$, for Kupreanof volcano and $\mathrm{Ph}$, for Pliocene(?) hypabyssal center. 
Table 1. Location and summit elevation of the Stepovak Bay volcanoes; base elevation increases northeastward from 600 to $900 \mathrm{~m}$

\begin{tabular}{lllc}
\hline $\begin{array}{c}\text { Volcano } \\
\text { or center }\end{array}$ & Latitude & Longitude & $\begin{array}{c}\text { Elevation } \\
(\mathrm{m})\end{array}$ \\
\hline Volcano 1 & $55.87^{\circ} \mathrm{N}$ & $160.09^{\circ} \mathrm{W}$ & 1,320 \\
Volcano 2 & $55.91^{\circ} \mathrm{N}$ & $160.04^{\circ} \mathrm{W}$ & 1,325 \\
Volcano 3 & $55.93^{\circ} \mathrm{N}$ & $160.00^{\circ} \mathrm{W}$ & 1,400 \\
Volcano 4 & $55.95^{\circ} \mathrm{N}$ & $159.96^{\circ} \mathrm{W}$ & 1,555 \\
Kupreanof & $56.01^{\circ} \mathrm{N}$ & $159.79^{\circ} \mathrm{W}$ & 1,895 \\
\hline
\end{tabular}

Peninsula because plutonic and chert clasts dominate over volcanic debris. The Milky River Formation crops out northwest of the volcanoes and consists of volcanic flows and agglomerate and sedimentary rocks composed mainly of volcanic detritus. At the type locality, located just northwest of Kupreanof volcano, the proportion of volcanic to sedimentary rocks increases upward (Detterman and others, 1981). The volcanic components of the Milky River are the earliest products of the Stepovak Bay volcanic centers. In the area immediately northwest of the volcanic centers, volcanic rocks dominate the Milky River Formation. Farther north, where the Milky River Formation is known only from drill core, sedimentary rocks composed of volcanic detritus dominate (Detterman and others, in press). In the Stepovak Bay region, the top of the Milky River Formation has not been defined, but it appears to be gradational with Pliocene and Pleistocene flows. On the southeast flank of the volcanic centers, the Eocene Tolstoi Formation crops out in a homoclinally southeast dipping section. In this area, the Tolstoi consists of fluvial siltstone, sandstone, and conglomerate. Thick welded(?) tuff deposits of uncertain but presumably late Tertiary age underlie volcano 1 , the southernmost of the volcanoes.

South of the volcanoes, undated but presumably Oligocene, propylitically altered volcanic rocks crop out in a large area. A dacite dike intruding these has been potassium-argon dated at $8.27 \pm 0.24 \mathrm{Ma}$ (DuBois and others, 1987). These altered volcanic rocks are probably part of the Meshik arc (Wilson, 1985), an Eocene to early Miocene precursor of the Aleutian arc. Overlying these 7 to $12 \mathrm{~km}$ south-southwest of volcano 1 is an area of Pliocene(?) flows. These Pliocene(?) flows are possibly related to a deeply eroded center (fig. 2, Ph); outcrops of hypabyssal rocks in a snowfield among these flows may be the root of this center.

At American Bay (fig. 2), the Oligocene volcanic rocks are intruded by a multiphase quartz diorite pluton of early Pliocene age (3.6 $\pm 0.10 \mathrm{Ma}$, K-Ar, Nora Shew and F.H. Wilson, unpub. data, 1988). This pluton is 12 to $15 \mathrm{~km}$ south of volcano 1 and only $8 \mathrm{~km}$ south of essentially coeval flows from the volcanoes.
Flows, agglomerates, and clastic rocks that are early products of the volcanoes occur north of a valley northwest of the line of volcanoes. These older flows and clastic rocks, in part included in the Milky River Formation, and in part overlying the Milky River Formation, dip gently away from the volcanic centers. We infer that a concealed fault (fig. 2) projects through this valley, primarily because use of the dip to project the flows back to the area of the eruptive centers indicates significant vertical offset. This fault is aligned parallel to the line of volcanoes and is upthrown to the northwest. The inferred fault is poorly defined in the vicinity of Kupreanof volcano.

\section{PETROGRAPHY}

Our rock samples from the Stepovak Bay volcanoes have a limited range of mineralogy and texture. All are porphyritic and have approximately 10 to 40 percent phenocrysts. Phenocrysts of clinopyroxene and plagioclase are common to all, and hornblende is conspicuously absent. Plagioclase compositions determined from Carlsbad-albite extinction angles (Kerr, 1977, p. 295-298) range between An 55 and An 90, but no compositions between An 70 and An 80 were observed. The only identified clinopyroxene is augite, which is usually twinned. Olivine phenocrysts occur in more than half the samples, whereas orthopyroxene is uncommon. In only 2 of 17 samples do both orthopyroxene and olivine occur. Orthopyroxene, where it occurs, generally has a reaction rim of clinopyroxene. Olivine is most common in rocks having plagioclase compositions of An 55 to 70, whereas orthopyroxene occurs in rocks of all plagioclase compositions. The groundmass ranges from glass to fine-grained holocrystalline mixtures of plagioclase, clinopyroxene, and opaque oxides.

Hyalopilitic or pilotaxitic textures dominate in the samples examined, but some rocks have hyalophitic to subophitic texture. In some samples, angular phenocrysts with sharp boundaries in a glassy groundmass suggest that the rock was quenched. Other samples are subophitic rocks composed of partly resorbed phenocrysts in a partially crystalline groundmass. In a few samples, polysynthetically twinned, weakly zoned plagioclase phenocrysts coexist with untwinned or albite-twinned and strongly zoned plagioclase phenocrysts. Optical determination of the composition for both types of plagioclase phenocrysts was not possible in these rocks. Wilson and others (1983) found that the albite-twinned plagioclase phenocrysts typically were of much lower An content than coexisting polysynthetically twinned phenocrysts in the area to the north of the volcanoes. Discrete grains of opaque oxides are a significant minor component in all samples. 


\section{CHEMISTRY}

The silica content of the lavas from Stepovak Bay volcanoes ranges from 50.3 to 62.7 percent (50.24 to 62.67 percent anhydrous, see table 2); using the IUGS chemical classification of volcanic rocks (Streckeisen, 1979) all samples are andesite, except for one, which is a leucobasalt. Using Gill's (1981) classification system for orogenic andesites, the rocks of the Stepovak Bay volcanoes that have anhydrous $\mathrm{SiO}_{2}$ contents greater than 53 percent are medium- $K$ orogenic andesite trending toward high-K orogenic andesite (fig. 3); samples that have less than 53 percent $\mathrm{SiO}_{2}$ are basalt. Rocks containing less than 54 percent $\mathrm{SiO}_{2}$ (anhydrous) are island arc tholeiites on the basis of a $\mathrm{MnO}-\mathrm{TiO}_{2}-\mathrm{P}_{2} \mathrm{O}_{5}$ ternary plot (fig. 4; Mullen, 1983). Chemical analyses (table 2) display slightly greater than normal iron-enrichment (fig. 5) for volcanic rocks of the Alaska Peninsula (see Wilson and others, 1983). There is no correlation with respect to age for assignment of a particular sample to either the tholeiitic or calc-alkaline classes.

\section{DISTRIBUTION, AGE, AND ERUPTIVE HISTORY}

\section{Pliocene and Pleistocene Products}

All the volcanoes contribute to extensive upper Tertiary and Quaternary lava flows that cap ridges and fill valleys in the vicinity of the volcanoes. In some cases, these flows extend to near sea level. The flows are particularly extensive northwest of volcano 1 and southeast of Kupreanof, however, remnants of the flows are distributed around all of the centers. The oldest ages typically come from rocks most distant from the present volcanic centers; however, this may largely reflect to outcrop patterns. Closer to the present eruptive centers, older rocks are covered by younger flows.

Potassium-argon dating (table 3 ) indicates that the area has been the locus of volcanic activity for approximately the last 4.7 million years. A $4.65-\mathrm{Ma}$ age was determined on an andesite flow (fig. 2 and table 3, locality 20) capping a ridge $9 \mathrm{~km}$ southwest of volcano 1 . In this area, the volcanic rocks are erosional remnants of flows that filled valleys. Clearly defined lobes from flows and gross structures indicating that lavas that poured from ridges into valleys are well preserved. Much of the area overlain by these flows and by nearby volcano 1 is composed of hydrothermally altered welded(?) tuff of unknown but presumably late Tertiary age (fig. 2).

Outcrops of hypabyssal rocks (fig. $2, \mathrm{Ph}$ ) in a snowfield 7 to $12 \mathrm{~km}$ south-southwest of volcano 1 among Pliocene(?) flows may indicate yet another eruptive center related to the Stepovak Bay volcanoes.
An age of $3.35 \mathrm{Ma}$ (locality 17, table 3 ) has been determined on an andesite flow $24 \mathrm{~km}$ west-northwest of volcano 1 . A $3.87 \mathrm{Ma}$ age (locality 16 , table 3 ) has also been determined on a nearby stratigraphically lower andesite flow. These flows cap ridges underlain by rocks of the Milky River and Bear Lake Formations on the east side of Port Moller bay. Seventeen kilometers north of volcano 1, a sample of an andesite flow has yielded an age of $1.70 \mathrm{Ma}$ (locality 21 , table 3 ). The flows, which are presumably related to the Stepovak Bay volcanoes, form an areally extensive cap on rocks of the Milky River and Bear Lake Formations. They must have been highly fluid on eruption because they extend up to $25 \mathrm{~km}$ from the volcanic centers, and dip gently northward toward the Bering Sea. Although these flows overlie the Milky River Formation in this locality, in the adjacent Chignik quadrangle to the north, an andesite flow of similar age (3.53 Ma, locality 5, table 3) is included in the upper part of the Milky River Formation (Detterman and others, 1981).

Two mafic andesite flows from Kupreanof volcano yield ages of $0.57 \mathrm{Ma}$ (locality 15 , table 3 ) and approximately $2.1 \mathrm{Ma}$ (Nora Shew and F.H. Wilson, unpub. data, 1988). Although these two flows are virtually identical chemically, the younger of the two flows is orthopyroxene, clinopyroxene, and olivine bearing whereas the older contains only clinopyroxene as a mafic phase. A clinopyroxene bearing leucobasalt flow from volcano 3 similar to the above flows from Kupreanof yielded a 1.48-Ma age (locality 7, table 3 ).

Remnants of late-glacial flows are found in the glaciated fault(?) valley northwest of the volcanoes and are further evidence of late Pleistocene volcanic activity.

Age determinations were attempted on three young andesite flows from volcano 1 . An age of $0.53 \mathrm{Ma}$ (locality 6, table 3) was obtained on a sample from volcano 1 . A second sample has yielded a preliminary age of $0.4 \mathrm{Ma}$ (Nora Shew and F.H. Wilson, unpub. data, 1988). Finally, we were unsuccessful in obtaining an age on the third sample; there was insufficient argon to calculate a reliable age (Nora Shew and F.H. Wilson, unpub. data, 1988). An estimated maximum age of approximately $0.05 \mathrm{Ma}$ can be calculated for this sample, based on the lower limit of argon concentration that our system can generally measure and the potassium content of the sample.

\section{Holocene Products}

All of the Stepovak Bay volcanoes except volcano 1 have clearly had Holocene eruptions. These eruptions produced three small debris flows from Kupreanof and volcano 4 into late Pleistocene glacial valleys, a short lava flow from volcano 3, and a small cinder cone and lava flow from volcano 2 (fig. 2). 
Table 2. Major element chemical analyses of rock samples from the Stepovak Bay volcanoes

[Localities 16, 17, 18, and 21 are west of the area shown on figure 2 . These locality numbers are the same numbers used on figures 3 through 5 . Volcanoes identified by volcano number or $\mathrm{K}$ for Kupreanof volcano]

\begin{tabular}{|c|c|c|c|c|c|c|c|}
\hline Locality & 1 & 2 & 3 & 4 & 5 & 6 & 7 \\
\hline Volcano & $\mathrm{K}$ & $\mathrm{K}$ & $\mathrm{K}$ & $\mathrm{K}$ & .- & 1 & 3 \\
\hline $\mathrm{SiO}_{2}$ & 55.50 & 56.10 & 50.70 & 58.60 & 55.34 & 57.50 & 50.30 \\
\hline $\mathrm{Al}_{2} \mathrm{O}_{3}$ & 19.20 & 18.70 & 18.90 & 16.60 & 15.94 & 16.70 & 18.00 \\
\hline $\mathrm{Fe}_{2} \mathrm{O}_{3}$ & 2.83 & 3.34 & 5.26 & 4.56 & 2.51 & 2.91 & 2.91 \\
\hline $\mathrm{FeO}$ & 5.23 & 5.03 & 3.90 & 3.51 & 5.41 & 5.22 & 6.83 \\
\hline MgO & 3.30 & 2.80 & 3.00 & 2.40 & 5.78 & 3.26 & 6.70 \\
\hline $\mathrm{CaO}$ & 8.09 & 8.27 & 9.70 & 6.17 & 8.35 & 7.08 & 11.30 \\
\hline $\mathrm{Na}_{2} \mathrm{O}$ & 3.40 & 3.10 & 2.80 & 3.90 & 2.90 & 3.39 & 2.21 \\
\hline $\mathrm{K}_{2} \mathrm{O}$ & 1.20 & 1.47 & 1.09 & 1.35 & 1.52 & 1.90 & .71 \\
\hline $\mathrm{TiO}_{2}$ & .86 & .97 & 1.12 & 1.12 & .94 & .94 & .80 \\
\hline $\mathrm{P}_{2} \mathrm{O}_{5}$ & .20 & .20 & .20 & .30 & .15 & .26 & .17 \\
\hline $\mathrm{MnO}$ & .16 & .15 & .13 & .19 & .14 & .17 & .18 \\
\hline $\mathrm{CO}_{2}$ & .08 & .41 & .27 & .32 & .18 & .09 & .11 \\
\hline $\mathrm{H}_{2} \mathrm{O}+$ & .31 & .45 & 1.12 & .12 & .64 & .25 & .40 \\
\hline $\mathrm{H}_{2} \mathrm{O}-$ & .11 & .21 & 1.87 & .22 & .59 & .24 & .17 \\
\hline Total & 100.47 & 101.2 & 100.06 & 99.36 & 100.39 & 99.91 & 100.79 \\
\hline $\mathrm{FeO}^{*}$ & 7.78 & 8.04 & 8.63 & 7.61 & 7.67 & 7.84 & 9.45 \\
\hline $\mathrm{FeO}^{*} / \mathrm{MgO}$ & 2.36 & 2.87 & 2.88 & 3.17 & 1.33 & 2.40 & 1.41 \\
\hline Latitude & 56.05 & 56.01 & 56.02 & 56.01 & 56.00 & 55.84 & 55.90 \\
\hline Longitude & 159.79 & 159.89 & 159.89 & 159.85 & 160.04 & 160.03 & 159.90 \\
\hline Field number & 78ARh 52 & 78ARh 55 & 78ARh 55A & 78ARh 56 & $78 \mathrm{AYb} 90$ & 82AWs 45 & 83AWs 97 \\
\hline
\end{tabular}

\begin{tabular}{|c|c|c|c|c|c|c|c|}
\hline Locality & 8 & 9 & 10 & 11 & 12 & 13 & 14 \\
\hline Volcano & 2 & 1 & 2 & 1 & 1 & $\mathbf{K}$ & $\mathbf{K}$ \\
\hline $\mathrm{SiO}_{2}$ & 62.70 & 59.90 & 58.40 & 54.40 & 53.20 & 55.80 & 51.20 \\
\hline $\mathrm{Al}_{2} \mathrm{O}_{3}$ & 16.30 & 16.50 & 16.80 & 16.90 & 16.30 & 16.40 & 17.20 \\
\hline $\mathrm{Fe}_{2} \mathrm{O}_{3}$ & 2.72 & 2.63 & 2.66 & 3.10 & 3.46 & 5.00 & 4.49 \\
\hline $\mathrm{FeO}$ & 3.41 & 4.28 & 4.44 & 6.02 & 5.26 & 4.07 & 4.72 \\
\hline $\mathrm{MgO}$ & 2.41 & 3.50 & 3.43 & 4.13 & 5.48 & 3.30 & 5.20 \\
\hline $\mathrm{CaO}$ & 5.29 & 6.39 & 7.22 & 8.02 & 8.92 & 7.13 & 9.26 \\
\hline $\mathrm{Na}_{2} \mathrm{O}$ & 3.79 & 3.40 & 3.26 & 3.21 & 2.87 & 3.00 & 2.40 \\
\hline $\mathrm{K}_{2} \mathrm{O}$ & 2.45 & 1.98 & 1.82 & 1.53 & 1.57 & 1.62 & 1.07 \\
\hline $\mathrm{TiO}_{2}$ & .70 & .78 & .77 & 1.04 & .93 & .93 & .88 \\
\hline $\mathrm{P}_{2} \mathrm{O}_{5}$ & .16 & .17 & .16 & .26 & .23 & .17 & .17 \\
\hline $\mathrm{MnO}$ & .12 & .14 & .14 & .17 & .15 & .17 & .15 \\
\hline $\mathrm{CO}_{2}$ & .09 & .02 & .02 & .02 & .02 & .73 & .87 \\
\hline $\mathrm{H}_{2} \mathrm{O}+$ & .30 & .33 & .57 & .31 & .41 & 1.32 & 1.79 \\
\hline $\mathrm{H}_{2} \mathrm{O}-$ & .07 & .12 & .14 & .45 & .96 & .14 & .26 \\
\hline Total & 100.51 & 100.14 & 99.83 & 99.56 & 99.76 & 99.78 & 99.66 \\
\hline $\mathrm{FeO}^{*}$ & 5.86 & 6.65 & 6.83 & 8.81 & 8.37 & 8.57 & 8.76 \\
\hline $\mathrm{FeO}^{*} / \mathrm{MgO}$ & 2.43 & 1.90 & 1.99 & 2.13 & 1.53 & 2.60 & 1.68 \\
\hline Latitude & 55.88 & 55.92 & 55.91 & 55.82 & 55.82 & 56.00 & 55.98 \\
\hline Longitude & 160.06 & 160.02 & 160.02 & 160.06 & 160.06 & 159.66 & 159.65 \\
\hline Field number & $83 A W s 108 a$ & $83 \mathrm{AYb} 522$ & 83AYb 523 & 83AYb 537 & $83 \mathrm{AYb} 538$ & $84 \mathrm{ADt} 192$ & 84AWs 176 \\
\hline
\end{tabular}

The easternmost of the debris or block-and-ash flows originates from Kupreanof volcano. It consists of well-compacted, chaotically mixed volcanic-lithic fragments and possibly juvenile material ranging from pebble size to nearly $10 \mathrm{~m}$ in diameter set in a mud and volcanic ash(?) matrix. The tongue-shaped flow is strongly iron- stained on weathered surfaces, and individual fragments are rich in disseminated pyrite. Similar debris flows originate from volcano 4 and flow in opposite directions from its summit. The northernmost of these traveled over, and came to rest on, an alpine glacier. The southernmost flowed down a valley toward the Pacific Ocean 
Table 2. Major element chemical analyses of rock samples from the Stepovak Bay volcanoes-Continued

\begin{tabular}{|c|c|c|c|c|c|c|c|c|}
\hline Locality & 15 & 16 & 17 & 18 & 19 & 20 & 21 & 22 \\
\hline Volcano & $\mathbf{K}$ & -- & -- & -- & 1 & -- & -- & 3 \\
\hline $\mathrm{SiO}_{2}$ & 51.40 & 55.10 & 55.70 & 54.00 & 54.20 & 59.00 & 55.80 & 56.60 \\
\hline $\mathrm{Al}_{2} \mathrm{O}_{3}$ & 18.10 & 17.50 & 16.90 & 16.20 & 17.70 & 16.10 & 17.00 & 17.30 \\
\hline $\mathrm{Fe}_{2} \mathrm{O}_{3}$ & 1.40 & 3.91 & 4.44 & 4.49 & $9.61^{1}$ & 3.84 & 2.39 & 4.04 \\
\hline $\mathrm{FeO}$ & 8.10 & 4.02 & 4.01 & 4.96 & -- & 3.26 & 5.42 & 4.23 \\
\hline $\mathrm{MgO}$ & 5.40 & 3.40 & 3.10 & 3.30 & 4.44 & 2.30 & 4.40 & 3.07 \\
\hline $\mathrm{CaO}$ & 10.10 & 8.08 & 6.80 & 7.64 & 8.60 & 5.62 & 8.58 & 7.32 \\
\hline $\mathrm{Na}_{2} \mathrm{O}$ & 2.40 & 3.20 & 3.40 & 3.60 & 3.03 & 3.90 & 2.90 & 3.50 \\
\hline $\mathrm{K}_{2} \mathrm{O}$ & .78 & 1.75 & 1.78 & 1.14 & 1.37 & 2.30 & 1.52 & 1.66 \\
\hline $\mathrm{TiO}_{2}$ & .85 & 1.03 & 1.12 & 1.42 & .94 & .94 & .82 & .96 \\
\hline $\mathrm{P}_{2} \mathrm{O}_{5}$ & .13 & .21 & .30 & .22 & .19 & .30 & .16 & .26 \\
\hline $\mathrm{MnO}$ & .17 & .13 & .13 & .18 & .16 & .14 & .15 & .16 \\
\hline $\mathrm{CO}_{2}$ & .22 & .28 & .48 & .74 & $-\infty$ & .43 & .06 & .38 \\
\hline $\mathrm{H}_{2} \mathrm{O}+$ & .05 & .65 & .57 & .96 & -- & .74 & .10 & .47 \\
\hline $\mathrm{H}_{2} \mathrm{O}-$ & .33 & .03 & .08 & .81 & -- & .14 & .07 & .30 \\
\hline Total & 99.43 & 99.29 & 98.81 & 99.66 & 100.24 & 99.01 & 99.37 & 100.24 \\
\hline $\mathrm{FeO}^{*}$ & 9.35 & 7.53 & 8.01 & 9.00 & 8.65 & 6.72 & 7.57 & 7.86 \\
\hline $\mathrm{FeO}^{*} / \mathrm{MgO}$ & 1.73 & 2.21 & 2.58 & 2.73 & 1.95 & 2.92 & 1.72 & 2.56 \\
\hline $\begin{array}{l}\text { Latitude } \\
\text {. }\end{array}$ & 55.98 & 55.92 & 55.95 & 55.89 & 55.86 & 55.82 & 55.96 & 55.96 \\
\hline Longitude & 159.66 & 160.47 & 160.45 & 160.31 & 160.15 & 160.23 & 160.28 & 160.05 \\
\hline Field number & 84AWs 177 & 84AWs 197 & 84AWs 199 & 84AWs 200 & 84AWs 204 & 84 AYb 633 & $85 \mathrm{AYb} 708$ & 86AWs 398 \\
\hline
\end{tabular}

1 All $\mathrm{Fe}$ reported as $\mathrm{Fe}_{2} \mathrm{O}_{3}, \mathrm{FeO}$ not measured.

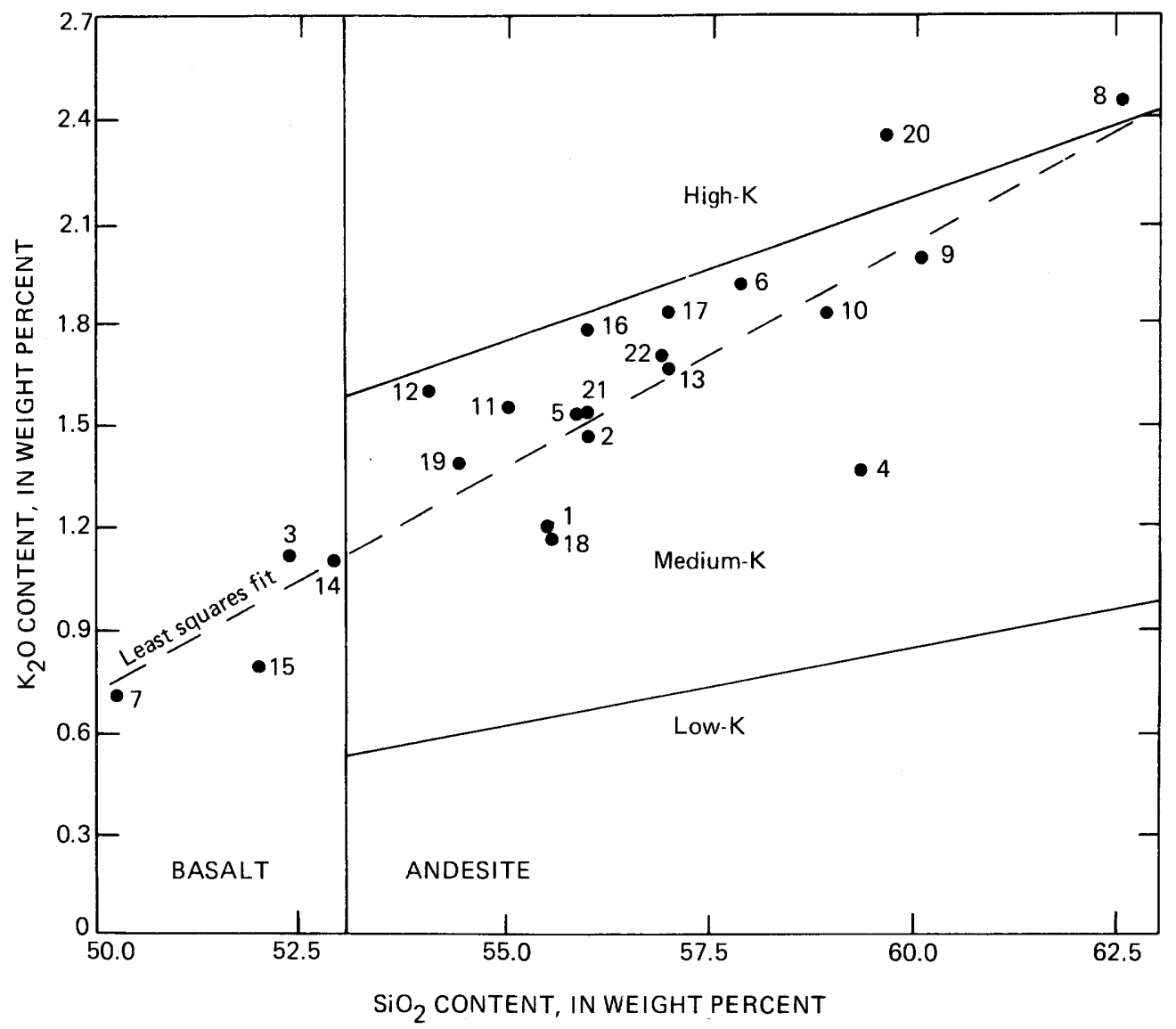

Figure 3. $\mathrm{K}_{2} \mathrm{O}$ versus $\mathrm{SiO}_{2}$ variation diagram for volcanic rocks of Stepovak Bay volcanoes showing boundaries between types of orogenic andesite and basalt as defined by Gill (1981). Sample numbers correspond to localities listed in table 2. 
and was localized by the moraine of a glacier occupying an adjacent valley. All three debris flows have been incised 30 to $40 \mathrm{~m}$ by modern streams. The summit of volcano 2 is a $200-\mathrm{m}$-high cinder cone. An andesite lava flow extends from this cone a kilometer or more down slope along an arcuate path northeast then southeast into a stream valley; additional material cascaded down the north flank of the volcano. Volcano 3 has a thick andesite flow originating from an ill-defined ice-filled summit crater $300 \mathrm{~m}$ in diameter. This flow traveled approximately $1 \mathrm{~km}$ southwest from the crater into the same stream valley as the flow from volcano 2 . Volcano 1 does not show unequivocal evidence of Holocene eruptive activity; however, it has an ice-filled summit crater of 500 $\mathrm{m}$ diameter that may be late Pleistocene in age. Holocene pyroclastic deposits are not conspicuous at any of the centers.

Maddren (1919) and Eakins (1970) reported an area of fumaroles north of Stepovak Bay. T.P. Miller (oral commun., 1982) reported of an area of fumaroles at Kupreanof volcano and it was commonly assumed that these were the same fumaroles. However, T.P. Miller (oral commun., 1988) later found that both Kupreanof volcano and volcano 4 had fumaroles (fig. 2). Aerial photographs from 1962 also suggest the presence of a fumarole on the southernmost of the centers, volcano 1 (fig. 2); however, U-2 aerial photographs taken in 1983 and our fieldwork did not further document this possible fumarole.

\section{DISCUSSION}

The Stepovak Bay volcanoes conform to some of the mineralogical, chemical, and textural characteristics of tholeiitic volcanic centers in the Aleutian arc as described by Kay and others (1982). The common characteristics include the absence of amphibole and the fact that most samples are tholeiitic on the basis of an $\mathrm{FeO}^{*} / \mathrm{MgO}$ versus $\mathrm{SiO}_{2}$ plot (fig. 6; Miyashiro, 1974). The Peacock alkali-lime index for these centers is 62 , which is typical of Alaska Peninsula volcanic rocks in general (Wilson and Shew, in press). This index is somewhat higher than the 57 to 59 considered normal by Kay and others (1982) for tholeiitic volcanic centers. Kay

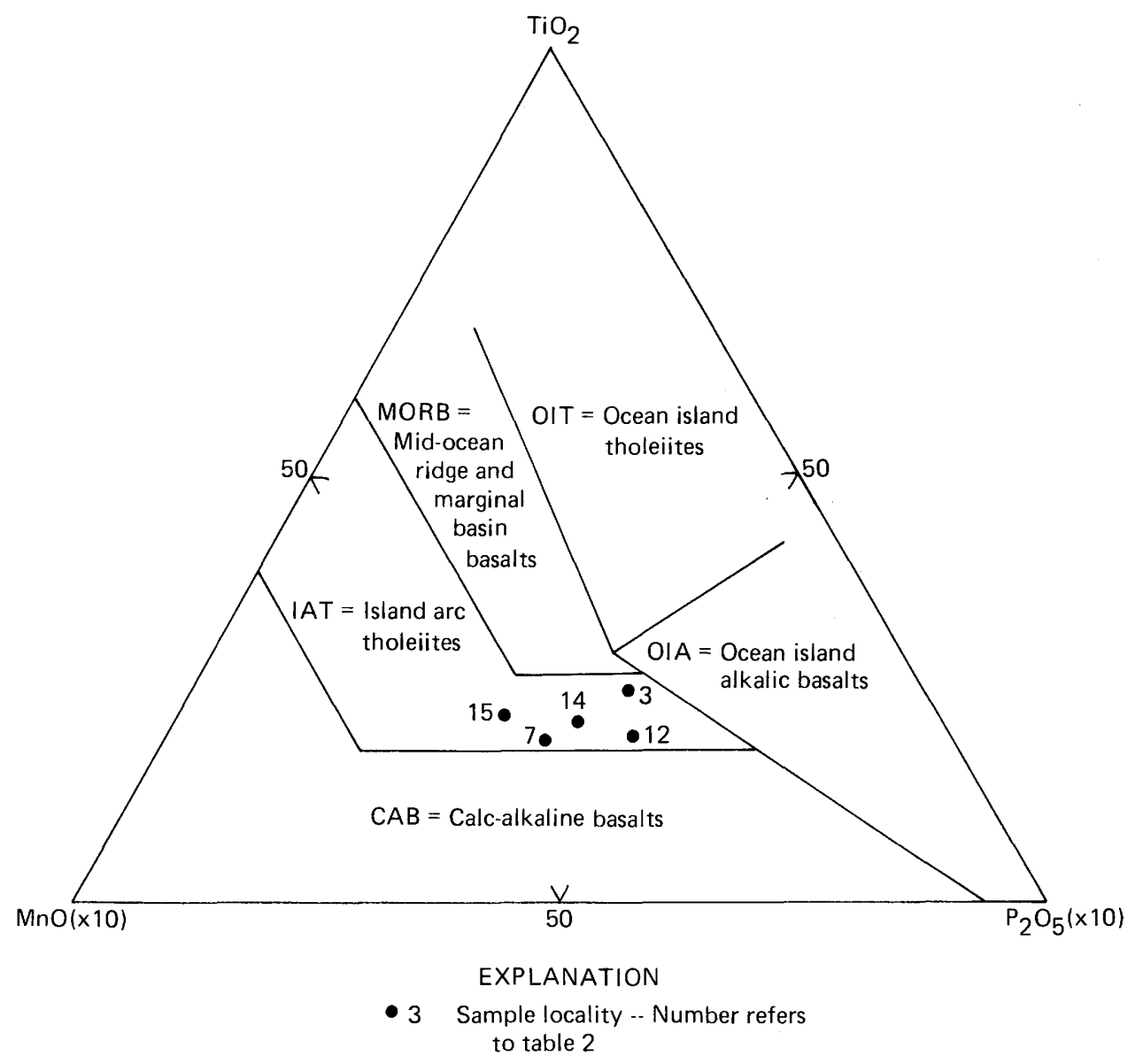

Figure 4. $\mathrm{MnO}(\times 10)-\mathrm{TiO}_{2}-\mathrm{P}_{2} \mathrm{O}_{5}(\times 10)$ ternary plot of volcanic rocks of Stepovak Bay volcanoes that have less than 54 percent $\mathrm{SiO}_{2}$ (anhydrous) showing these rocks are island arc tholeiites (after Mullen, 1983). 
and others (1982) suggested that andesite and dacite vitrophyres are restricted to the tholeiitic series in the Aleutian arc. However, though glass is common in the groundmass of about two-thirds of the samples from the Stepovak Bay volcanoes, this is not unusual for calcalkaline and tholeiitic rocks on the Alaska Peninsula (Wilson and others, 1983, Riehle and others, 1987). Chemical data and standard discrimination diagrams suggest that the Stepovak Bay volcanoes should be considered fundamentally tholeiitic volcanic centers, though some calc-alkaline lavas have erupted. However, there are insufficient data to determine if the centers show evolution or systematic variation of magma chemistry with time.

Kay and others (1982) suggested there are tectonic controls on arc magmatism, and they proposed that tholeiitic volcanic centers occur at the ends of and between segments of the volcanic arc, whereas calcalkaline centers occur within volcanic arc segments. They considered Mount Veniaminof, immediately to the northeast of the Stepovak Bay volcanoes, a tholeiitic volcanic center and used it to define the eastern end of their Cold Bay volcanic arc segment. By implication then, as within-segment volcanoes, the Stepovak Bay volcanoes should be calc-alkaline. However, the chemical and petrographic data for the Stepovak Bay volcanoes suggest they are best defined as tholeiitic volcanic centers though they exhibit some characteristics transitional to calcalkaline rocks. On the basis of the Kay and others (1982) arc segment definition, it appears incorrect to terminate the Cold Bay arc segment at Mount Veniaminof. Possibly, the $65-\mathrm{km}$-long section of the Aleutian arc defined by the Stepovak Bay volcanoes and Mount Veniaminof represents a tholeiitic between-segment portion of the arc, as defined by Kay and others (1982). This would require the Cold Bay arc segment to end somewhere west of the Stepovak Bay volcanoes. Alternatively, by inclusion of the Stepovak Bay volcanoes to Mount Veniaminof

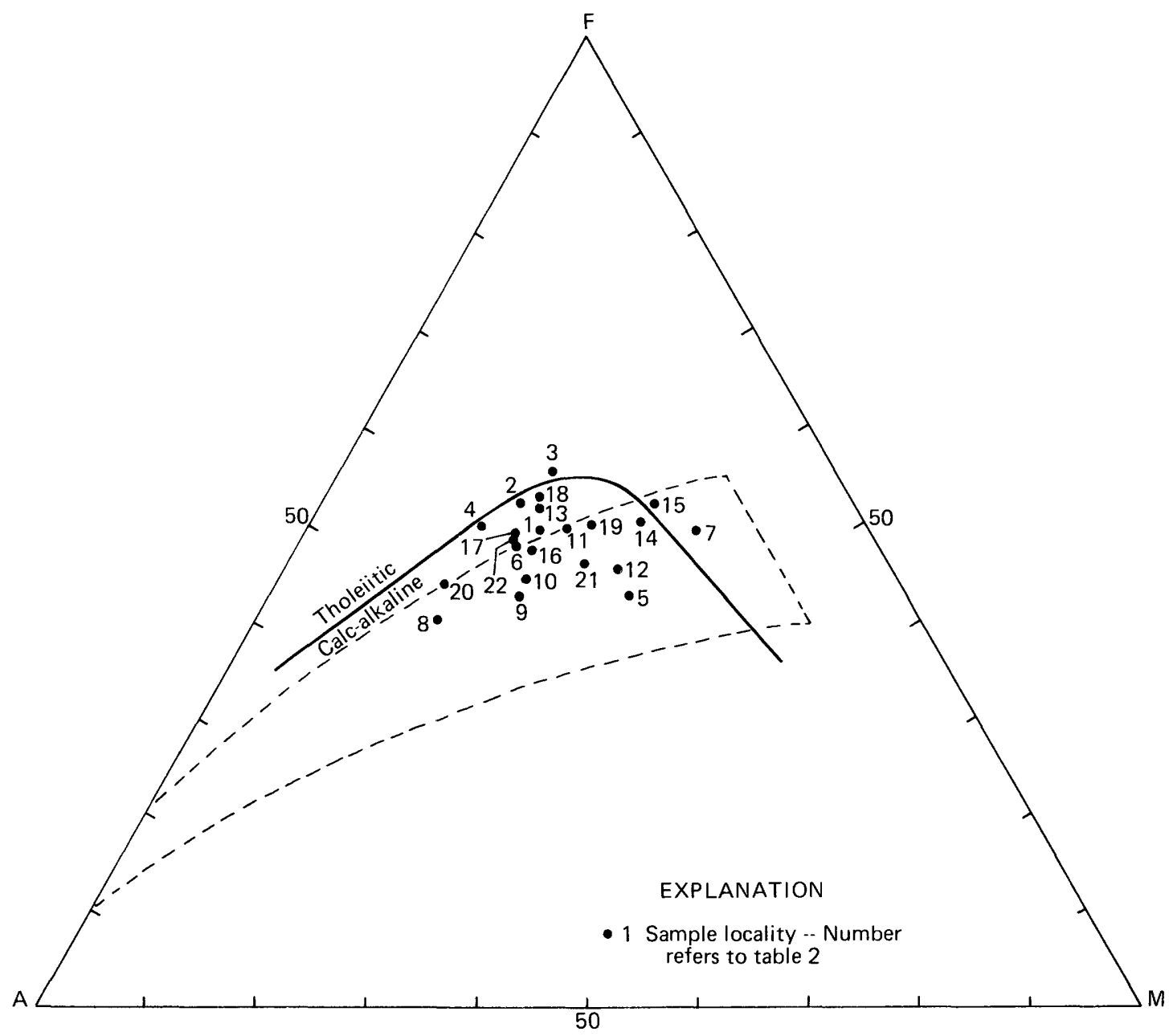

Figure 5. AFM ternary diagram of volcanic rocks of Stepovak Bay volcanoes showing slightly greater than normal iron enrichment. Dashed line indicates field for calc-alkaline rocks of Ringwood (1977) and solid line indicates division between tholeiitic and calc-alkaline rocks of Irvine and Baragar (1971). $A$ is $\mathrm{Na}_{2} \mathrm{O} \pm \mathrm{K}_{2} \mathrm{O}$, $\mathrm{F}$ is total iron, calculated as $\mathrm{FeO}$, and $\mathrm{M}$ is $\mathrm{MgO}$. 


\section{Table 3. K-Ar age determinations of rocks forming the Stepovak Bay volcanoes}

[Age determinations calculated using the following constants: $\lambda_{\epsilon}=5.72 \times 10^{-10} \mathrm{year}^{-1}, \lambda_{\varepsilon^{\prime}}=8.78 \times 10^{-18}$ year $^{-1}, \lambda_{\beta}=4.962 \times 10^{-10} \mathrm{year}^{-1}{ }^{40} \mathrm{~K} / \mathrm{K}$ $=1.167 \times 10^{-4}$ atom percent. Argon analysis and age calculation by Nora Shew and F.H. Wilson, potassium analysis by Sarah Neil, Stuart McPherson, Byron Lai, Terry Fries, and Larry Espos, U.S. Geological Survey. Potassium was determined using lithium metaborate fusion and flame photometry, generally following the methods of Engels and Ingamells (1970). Argon extraction and measurement were done using techniques of isotope-dilution mass spectrometry as generally described by Dalrymple and Lanphere (1969), with modification presented by Wilson (1980). The error assigned to each age is an estimate of the standard deviation of analytical precision using the method of Cox and Dalrymple (1967), together with an estimate of precision based on evaluation of the uncertainties in the concentration of the argon tracer and potassium measurements. All potassium and argon analyses were done in duplicate]

\begin{tabular}{|c|c|c|c|c|c|c|c|c|}
\hline $\begin{array}{l}\text { Locality } \\
\text { and field } \\
\text { number }\end{array}$ & $\begin{array}{l}\text { Rock type } \\
\text { and mineral } \\
\text { dated }\end{array}$ & Latitude & Longitude & $\begin{array}{l}\mathrm{K}_{2} \mathrm{O} \\
\text { average } \\
\text { percent }\end{array}$ & $\begin{array}{l}{ }^{40} \mathrm{Ar}_{\mathrm{rad}} \\
\times 10^{-12}\end{array}$ & $\begin{array}{l}\mathrm{Ar}_{\text {rad }} \\
\text { percent }\end{array}$ & $\begin{array}{l}\text { Age } \\
\text { (Ma) }\end{array}$ & $\begin{array}{l}\text { Error } \\
\text { m.y. }\end{array}$ \\
\hline 5 & Andesite & $56.00^{\circ} \mathrm{N}$ & $160.04^{\circ} \mathrm{W}$ & 1.382 & 7.346 & 32.15 & & \\
\hline 78AYb 90 & & & & & 6.701 & 36.72 & 3.53 & 0.27 \\
\hline 6 & Andesite & $55.84^{\circ} \mathrm{N}$ & $160.03^{\circ} \mathrm{W}$ & .356 & .322 & 7.07 & & \\
\hline 82AWs 45 & & & & & .225 & 5.01 & .53 & .14 \\
\hline 7 & Leuco- & $55.90^{\circ} \mathrm{N}$ & $159.90^{\circ} \mathrm{W}$ & .094 & 1.4949 & 2.39 & & \\
\hline \multirow[t]{3}{*}{ 83AWs 97} & basalt, & & & & 2.5347 & 4.41 & & \\
\hline & plagioclase & & & & 2.0167 & 3.27 & & \\
\hline & & & & & 1.9497 & 3.81 & 1.48 & .36 \\
\hline 15 & Andesite, & $55.98^{\circ} \mathrm{N}$ & $159.66^{\circ} \mathrm{W}$ & .104 & .0891 & 1.58 & & \\
\hline 84AWs 177 & plagioclase & & & & .0808 & 1.62 & .57 & .06 \\
\hline 16 & Andesite, & $55.92^{\circ} \mathrm{N}$ & $160.47^{\circ} \mathrm{W}$ & 1.562 & 8.6887 & 75.9 & & \\
\hline 84AWs 197 & plagioclase & & & & 8.7360 & 56.5 & 3.87 & .06 \\
\hline 17 & Andesite, & $55.95^{\circ} \mathrm{N}$ & $160.45^{\circ} \mathrm{W}$ & .376 & 1.7686 & 35.6 & & \\
\hline 84AWs 199 & plagioclase & & & & 1.8507 & 35.5 & 3.35 & .12 \\
\hline 20 & Andesite, & $55.82^{\circ} \mathrm{N}$ & $160.23^{\circ} \mathrm{W}$ & .416 & 2.7809 & 45.1 & & \\
\hline $84 \mathrm{AYb} 633$ & plagioclase & & & & 2.7861 & 39.1 & 4.65 & .07 \\
\hline 21 & Andesite, & $55.96^{\circ} \mathrm{N}$ & $160.29^{\circ} \mathrm{W}$ & .906 & 2.1982 & 47.2 & & \\
\hline $85 \mathrm{AYb} 708$ & plagioclase & & & & 2.2447 & 53.3 & 1.70 & .03 \\
\hline
\end{tabular}

section of the arc in the spatially well-defined Chignik arc segment, tholeiitic centers may only indicate the position of areas of rapid magma transport to the upper crust.

The available data suggest major tilting and differential uplift from the southeast along the axis of the Alaska Peninsula. This tilting and differential uplift has combined with glaciation to result in the best preservation of the Milky River Formation and the Stepovak Bay volcanoes on the northwest side of the Alaska Peninsula. The evidence in support of tilting and differential uplift includes the exposure of the pluton at American Bay, which is similar to plutons associated with porphyry copper systems. A depth of emplacement of 1.5 to $3 \mathrm{~km}$ or more is typically suggested for the porphyritic plutons in models of copper porphyry systems (Sillitoe, 1973; Sutherland Brown, 1976). This is also a reasonable estimate of the depth of emplacement for the quartz diorite pluton of early Pliocene age at American Bay only $8 \mathrm{~km}$ south of essentially coeval flows from the Stepovak Bay volcanoes. Erosion of approximately $2 \mathrm{~km}$ of cover was probably required to expose this pluton and indicates tremendous differential erosion compared to the nearby volcanic flows. No major fault systems have been mapped between the exposures of plutonic and volcanic rocks, hence tilting and differential uplift are good explanations for the observed effect. Additionally, raised terraces, uplifted sea caves on the Pacific Ocean coast, drowned moraines on the Bering Sea coast, and other field evidence (R.L. Detterman, F.R. Weber, and F.H. Wilson, unpub. data, 1988) support the suggestion of differential uplift on the Alaska Peninsula. Quaternary glaciers flowed from the south and southwest and were 


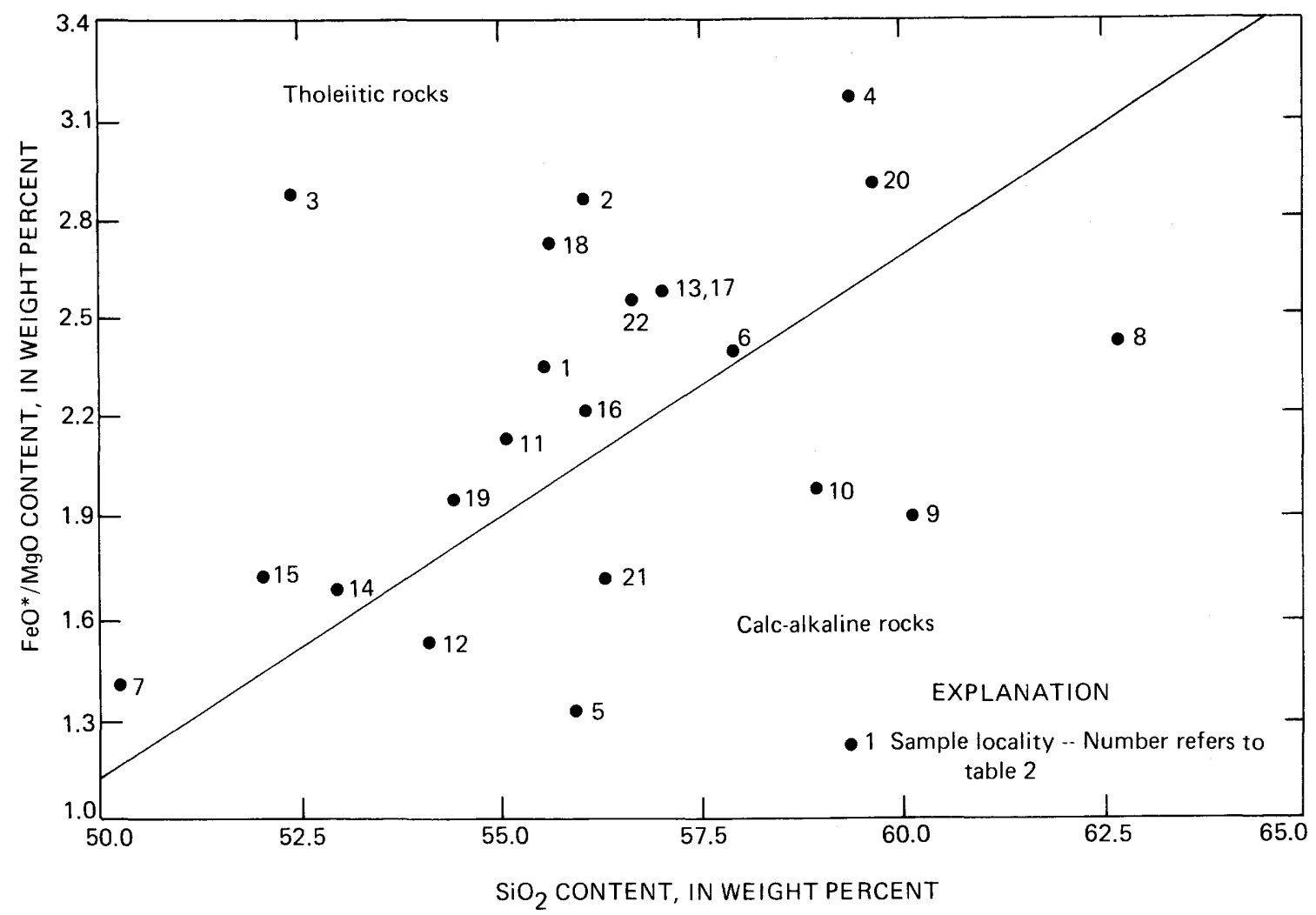

Figure 6. $\mathrm{FeO} * / \mathrm{MgO}$ versus $\mathrm{SiO}_{2}$ variation diagram for volcanic rocks of Stepovak Bay volcanoes showing that most rocks are tholeiitic. $\mathrm{FeO}^{\star}$ is total iron, calculated as FeO. Boundary between tholeiitic and calc-alkaline fields after Miyashiro (1974).

largest on the southeast side of the Alaska Peninsula in this area (Weber, 1985); this glaciation caused the preferential removal of rocks on the southeast.

\section{SUMMARY OF CONCLUSIONS}

Three of the five Stepovak Bay volcanoes were first recognized as Quaternary volcanic centers in 1982, and an additional one was recognized in later field work. The five volcanoes represent the latest phase of more than 4.65 million years of eruptive activity north of Stepovak Bay. As such, they represent one of the longest lived active volcanic centers on the Alaska Peninsula. The oldest products of the volcanoes were voluminous andesite flows. These flows, in part mapped in the Milky River Formation, are now exposed capping most of the ridges in the vicinity of the volcanoes. Holocene eruptive activity has consisted of a number of debris and lava flows from at least four of the volcanoes, and at present there are active fumaroles on two of the volcanoes. Volcanic eruptions have occurred along the entire of the chain of volcanic centers throughout their history.

Rocks erupted throughout the history of the volcanoes have a limited range of mineralogy and texture. Plagioclase compositions range widely, and the presence of olivine is correlated with the lowest An-content plagi- oclase. The Stepovak Bay volcanoes are generally tholeiitic and occur at the southeast end of the herein defined Chignik segment of the Aleutian arc.

Data from the volcanoes and nearby plutonic rocks agree with other data that suggest major tilting and differential uplift from the southeast along the axis of the Alaska Peninsula. In combination with glaciation, this has resulted in the best preservation of the volcanoes on the northwest side of the Alaska Peninsula.

\section{REFERENCES CITED}

Burk, C.A., 1965, Geology of the Alaska Peninsula - Island arc and continental margin: Geological Society of America Memoir 99, 250 p., scales 1:250,000 and 1:500,000, 3 sheets.

Case, J.E., Cox, D.P., Detra, D.E., Detterman, R.L., and Wilson, F.H., 1981, Maps showing aeromagnetic study and geologic interpretation of the Chignik and Sutwik (Island) quadrangles, Alaska: U.S. Geological Survey Miscellaneous Field Studies Map MF-1053B, 8 p., 2 maps, scale 1:250,000.

Case, J.E., Detterman, R.L., Wilson, F.H., Chuchel, B.A., and Yount, M.E., 1987, Maps showing aeromagnetic study and geologic interpretation of parts of the Ugashik and Karluk quadrangles, Alaska: U.S. Geological Survey 
Miscellaneous Field Studies Map MF-1539D, 12 p., 2 maps, scale 1:250,000.

Coats, R.R., 1950, Volcanic activity in the Aleutian arc: U.S. Geological Survey Bulletin 974-B, p. 35-49.

Cox, Allan, and Dalrymple, G.B., 1967, Statistical analysis of geomagnetic reversal data and the precision of potassium-argon dating: Journal of Geophysical Research, v. 72, p. 2603-2614.

Dalrymple, G.B., and Lanphere, M.A., 1969, Potassium-argon dating, principles, techniques, and applications to geochronology: San Francisco, W.H. Freeman, 258 p.

Davies, J.N., Sykes, L.R., House, Leigh, and Jacob, Klaus, 1981, Shumagin seismic gap, Alaska Peninsula: History of great earthquakes, tectonic setting, and evidence for high seismic potential: Journal of Geophysical Research, v. 86, no. 5, p. 3821-3855.

Detterman, R.L., Miller, T.P., Yount, M.E., and Wilson, F.H., 1981, Geologic map of the Chignik and Sutwik Island quadrangles, Alaska: U.S. Geological Survey Miscellaneous Investigations Series Map I-1229, scale 1:250,000.

Detterman, R.L., Case, J.E., Wilson, F.H., and Yount, M.E., 1987, Geologic map of the Ugashik, Bristol Bay, and western part of Karluk quadrangle, Alaska: U.S. Geological Survey Miscellaneous Investigations Series Map I-1685, scale 1:250,000.

Detterman, R.L., Case, J.E., Miller, J.W., Wilson, F.H., and Yount, M.E., in press, Stratigraphic framework of the Alaska Peninsula: U.S. Geological Survey Bulletin.

DuBois, G.D., Wilson, F.H., and Shew, N.B., 1987, Potassiumargon age determinations from the Port Moller and Stepovak Bay quadrangles, Alaska Peninsula: U.S. Geological Survey Open-File Report 87-191, 1 map, scale $1: 250,000$.

Eakins, G.R., 1970, Mineralization near Stepovak Bay, Alaska Peninsula, Alaska: Alaska Division of Mines and Geology Special Report 4, 12 p.

Engels, J.C., and Ingamells, C.O., 1970, Effect of sample inhomogeneity in $\mathrm{K}-\mathrm{Ar}$ dating: Geochimica et Cosmochimica Acta, v. 34, p. 1007-1017.

Gill, J.B., 1981, Orogenic andesites and plate tectonics: Berlin, Springer-Verlag, $390 \mathrm{p}$.

Irvine, T.N., and Baragar, W.R., 1971, A guide to the chemical classification of the common igneous rocks: Canadian Journal of Earth Sciences, v. 8, p. 523-548.

Kay, S.M., Kay, R.W., and Citron, G.P., 1982, Tectonic controls on tholeitic and calc-alkaline magmatism in the Aleutian arc: Journal of Geophysical Research, v. 87, no. B5, p. 4051-4072.

Kerr, P.F., 1977, Optical mineralogy, 4th edition: New York, McGraw-Hill, 492 p.

Maddren, A.G., 1919, Sulphur on Unalaska and Akun Islands and near Stepovak Bay: U.S. Geological Survey Bulletin 692E, p. 283-298.

Miyashiro, A., 1974, Volcanic rock series in island arcs and active continental margins: American Journal of Science, v. 274, p. 321-355.

Mullen, E.D., 1983, $\mathrm{MnO} / \mathrm{TiO}_{2} / \mathrm{P}_{2} \mathrm{O}_{5}$ : A minor element discriminant for basaltic rocks of oceanic environment and its implications for petrogenesis: Earth and Planetary Science Letters, v. 62, p. 53-62.

Palache, Charles, 1904, Geology about Chichagof Cove, Stepovak Bay; with notes on Popof and Unga Islands (Alaska): Harriman Alaska Expedition, v. 4, p. 69-88.

Riehle, J.R., Yount, M.E., and Miller, T.P., 1987, Petrography, chemistry, and geologic history of Yantarni volcano, Aleutian volcanic arc, Alaska: U.S. Geological Survey Bulletin 1761, 27 p., 1 plate, scale 1:63,360.

Ringwood, A.E., 1977, Petrogenesis in island arc systems, in Talwani, Manik, and Pitman, W.C., III, eds., Island arcs, deep sea trenches and back-arc basins: American Geophysical Union, Maurice Ewing Series, v. 1, p. 311-324.

Sillitoe, R.H., 1973, The tops and bottoms of porphyry copper deposits: Economic Geology, v. 67, p. 799-815.

Streckeisen, Albert, 1979, Classification and nomenclature of volcanic rocks, lamprophyres, carbonatites, and melilitic rocks: Recommendations and suggestions of the IUGS Subcommission on the Systematics of Igneous Rocks: Geology, v. 7, p. 331-335.

Sutherland Brown, A., 1976, Morphology and classification, in Sutherland Brown, A., ed., Porphyry copper deposits of the Canadian Cordillera: Canadian Institute of Mining and Metallurgy, Special Volume 15, p. 44-51.

Weber, F.R., 1985, Late Quaternary glaciation of the Pavlof Bay and Port Moller areas, Alaska Peninsula, in BartschWinkler, ed., The United States Geological Survey in Alaska: Accomplishments during 1984: U.S. Geological Survey Circular 967, p. 42-44.

Wilson, F.H., 1980, Late Mesozoic and Cenozoic tectonics and the age of porphyry copper prospects; Chignik and Sutwik Island quadrangles, Alaska Peninsula: U.S. Geological Survey Open-File Report 80-543, 94 p., 5 plates.

Wilson, F.H., 1985, The Meshik arc-An Eocene to earliest Miocene magmatic arc on the Alaska Peninsula: Alaska Division of Geological and Geophysical Surveys Professional Report 88, 14 p.

Wilson, F.H., Gaum, W.C., and Herzon, P.L., 1983, Map and tables showing geochronology and whole-rock geochemistry of the Chignik and Sutwik Island quadrangles, Alaska: U.S. Geological Survey Miscellaneous Field Studies Map MF-1053 M, 3 sheets, scale 1:250,000.

Wilson, F.H., and Shew, Nora, in press, Map and tables showing geochronology and whole-rock geochemistry of selected samples, Ugashik and part of Karluk quadrangles, Alaska: U.S. Geological Survey Miscellaneous Field Studies Map MF-1539-E, 44 p., scale 1:250,000.

Yount, M.E., Wilson, F.H., and Miller, J.W., 1985, Newly discovered Holocene volcanic vents, Port Moller and Stepovak Bay quadrangles, Alaska Peninsula, in BartschWinkler, Susan, and Reed, K. M., eds., The United States Geological Survey in Alaska: Accomplishments in 1983: U.S. Geological Survey Circular 945, p. 60-62.

\section{Reviewers:}
R.G. McGimsey
D.H. Richter 


\title{
Creation of a Full Color Geologic Map by Computer: A Case History from the Port Moller Project Resource Assessment, Alaska Peninsula
}

\author{
By Frederic $\mathrm{H}$. Wilson
}

\begin{abstract}
Graphics programs on computers can facilitate the compilation and production of geologic maps, including full color maps of publication quality. This paper describes the application of two different programs, GSMAP and ARC/INFO, to the production of a geologic map of the Port Moller and adjacent 1:250,000-scale quadrangles on the Alaska Peninsula. GSMAP was used at first because of easy digitizing on inexpensive computer hardware. Limitations in its editing capability led to transfer of the digital data to ARC/INFO, a Geographic Information System, which has better editing and also added data analysis capability. Although these improved capabilities are accompanied by increased complexity, the availability of ARC/INFO's data analysis capability provides unanticipated advantages. It allows digital map data to be processed as one of multiple data layers for mineral resource assessment. As a result of development of both software packages, it is now easier to apply both software packages to geologic map production. Both systems accelerate the drafting and revision of maps and enhance the compilation process. Additionally, ARC/ INFO's analysis capability enhances the geologist's ability to develop answers to questions of interest that were previously difficult or impossible to obtain.
\end{abstract}

\section{INTRODUCTION}

Graphics programs on computers, and in particular microcomputers, can facilitate the compilation and production of geologic maps in the same way that word processing software facilitates the production of text. This paper describes an attempt to apply this graphics technology to a mapping and mineral resource assessment project. The initial goal was to be able to rapidly prepare a geologic map ready for publication as a full color 1:250,000-scale map from field data. As the project developed, enhanced capabilities resulted from rapidly advancing computer and graphics technology and from program modifications using that new technology. These greater capabilities allowed modification of the scope of our project goals. The digital format of the map data was found to be useful in computer processing for other phases of the mineral resource assessment process; it also enhanced the assessment by allowing evaluation of the data in new ways.

Geologic mapping and resource assessment of the Port Moller, Stepovak Bay, and Simeonof Island 1:250,000-scale quadrangles on the Alaska Peninsula (fig. 1) is part of the Alaska Mineral Resource Assessment Program (AMRAP). A multidisciplinary team including F.H. Wilson, R.L. Detterman, J.W. Miller, J.E. Case, M.E. Yount, and L.M. Angeloni conducted field mapping during the 1982 through 1986 field seasons. Previous mapping by Atwood (1911), Burk (1965), Kennedy and Waldron (1955), and Moore (1974) provided an excellent framework for the AMRAP mapping; however, extensive changes to most of the existing maps were required. These changes were due, in part, to reinterpretation of the regional stratigraphic framework and the availability of better topographic maps. Data collected for the geologic map were obtained from traverses, helicopter spot landings, aerial photography, and Landsat imagery.

Field data were plotted on 1:63,360-scale stable base maps. These maps were then digitized directly to take advantage of computer scale conversion because in the case of the Port Moller quadrangle, their topography is more accurate than the existing 1:250,000-scale topographic map produced as part of the Alaska Reconnaissance Series. For the Stepovak Bay and Simeonof Island quadrangles, the 1:250,000-scale topographic maps are adequate publication bases.

\section{COMPUTER-AIDED MAP PREPARATION SOFTWARE}

Advances in computer hardware and software have made possible the computer production of geologic maps. This capability theoretically allows rapid production and editing of maps that are of equivalent or higher quality than traditional hand-drafted maps. It also allows 
selection of specific types of features from a single map data file to produce maps of many different kinds, tailored to specific uses or audiences. However, use of these computer capabilities requires a conceptual rethinking of what defines a geologic map. A field station, strike and dip measurement, or a fossil collection locality is a point on the map with particular characteristics, not limited to the measurement or collection, but including the location in space. Faults, stratigraphic contacts, and fold axes can be thought of as types of lines that have other characteristics, which are referenced through a coding scheme or an attribute, attached to define these characteristics. Areas of particular geologic units become polygons with attributes to define their characteristics. Depending on the software in use, this may be a single number code referencing a list on paper, or it may be a link to a data base with fields for a variety of characteristics of that geologic unit and polygon. Some software will establish topology, defined as a mathematical procedure for explicitly defining spatial relations (Environmental Systems Research Institute, 1987, volume 1, p.
3-7). The field stations, faults, and outcrop areas we are familiar with, mathematically are dealt with as points, lines, and polygons with associated attributes. With the creation of topological structure, characteristics defined for polygons include area and bounding lines, in addition to geologic unit. For a line, characteristics defined include the polygons that it bounds, the points or nodes that it connects, and the starting and ending locations (hence, the direction).

Computer software for mapping use tends to be of two basic types, automated mapping (AM) software or Geographic Information Systems (GIS). A fundamental difference is that $A M$ software is unlikely to establish topology, whereas GIS software generally will. A third type of software, computer-aided drafting (CAD) software, is similar to AM software, except that it usually does not allow the cartographic projection of a map to be changed. GSMAP is an example of automated mapping (AM) software, whereas ARC/INFO (Environmental Systems Research Institute, 1987) is an example of GIS software. Any particular program, or group of programs,
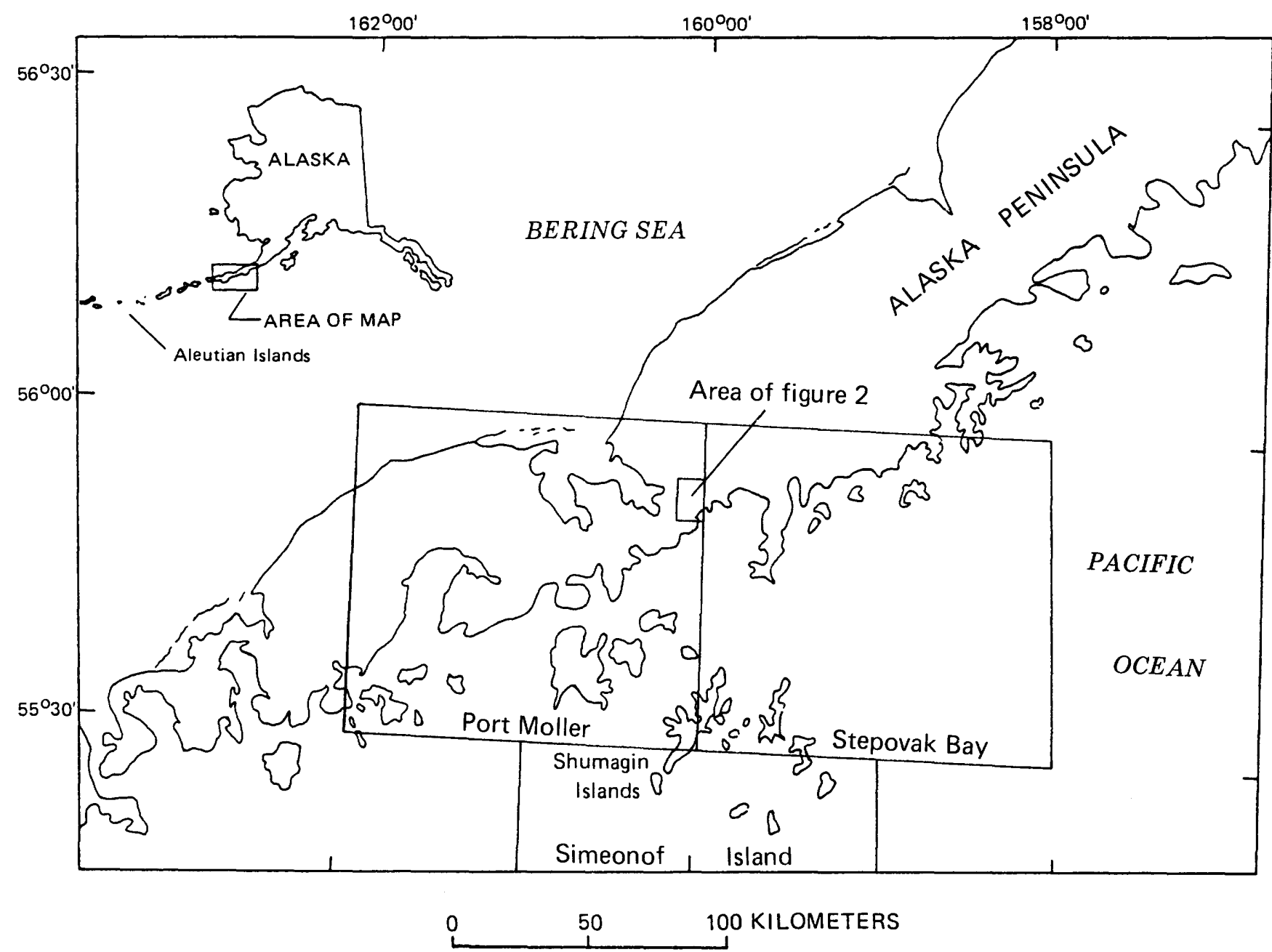

Figure 1. Location of Port Moller project area shown by 1:250,000-scale quadrangles. 
may actually have features of more than one of these categories.

When the Port Moller project was started, none of the project personnel were aware of the distinctions between computer mapping systems; only Wilson was moderately computer literate. We would have been unable to clearly define the desirable characteristics for software to produce a geologic map (table 1). When we were confronted with the problem of compiling our field data, the first versions of GSMAP (Selner and others, 1986a, 1986b), an AM program developed for IBMcompatible microcomputers, had just became available. It had characteristics that appeared valuable for computer-based map compilation. Demonstration by G.I. Selner (oral and written commun., 1986) of its ability to produce high-quality output led us to select it for the production of the Port Moller AMRAP geologic map. It was important that any system selected be readily understandable by project personnel. GSMAP appeared to meet that criterion, ran on previously acquired and readily available hardware, and was free of cost. At the time, we were unaware of ARC/INFO and did not have ready access to it.

\section{INITIAL COMPILATION: USE OF GSMAP}

\section{Digital Compilation}

Initially, maps were digitized after the extrapolation of geologic contacts and interpretation of geologic relations between units for each 1:63,360 map sheet was made by hand. Digitizing was performed with version 2 of GSMAP (G.I. Selner, R.B. Taylor, and B.R. Johnson, U.S. Geological Survey, unpub. program, 1986), a slightly modified and compiled edition of the published version 1 (Selner and others, 1986a). As digitizing proceeded, it was found that this extrapolation and interpretation was not required prior to digitizing. The synthesis of the field data was postponed until the data was input to GSMAP, as our skill and familiarity with GSMAP developed. We discovered that GSMAP and similar programs not only served as useful tools to help with the production of geologic maps, they were also useful in the synthesis of field data.

GSMAP is written in the BASIC computer language, which allows relatively novice users to modify the program. As the Port Moller project proceeded, I made a number of modifications to GSMAP to simplify use or to add capabilities necessary or desired (see table 1). Halfway though the digitizing of the Port Moller project map, version 3.0 of GSMAP (Selner and others, 1986b) was released. This version changed the data file format and necessitated the development of a conversion program (Selner, unpub. program, 1986) to convert map data files from earlier versions of GSMAP. Whereas earlier versions of GSMAP stored data in rectangular coordinates, in version 3.0 they were stored in geographic coordinates (degrees). G.I. Selner also made available a program (GSM2ARC.BAS, unpub. program, 1986) to convert GSMAP data files to a format readable by ARC/INFO. Upon the development of GSM2ARC, I incorporated my modifications of version 2 of GSMAP into version 3.0, and transferred our existing data files.

A draft geologic map for technical review (see fig. 2) was produced with GSMAP, and the gross editing resulting from the technical reviews was completed prior to transfer to ARC/INFO. The map shown in figure 2 is an incomplete draft; a completed geologic map produced with GSMAP was published as map MF-1922 (du Bray and others, 1987). At the time for technical review of the Port Moller map, it was clear that GSMAP had significant limitations. It had proved to be adequate to enter and do gross editing of the map, but fine editing, such as the shift of a portion of a line, was prone to error (see table 1). Some of these limitations can be shown on figure 2. At arrow 1, on the figure, is an example showing a solid line that was digitized slightly too long and overshot the end of the joining dashed line. To correct this in GSMAP, the entire line must be redigitized; in ARC/INFO the excess can be quickly clipped off. At arrows 2 and 3, lines end without enclosing areas. The line at arrow 2 is a contact, dividing different geologic units and therefore must be continued to a boundary to define the extent of both geologic units. Locating this type of small error is difficult onscreen in GSMAP, and many were found by hand coloring a plot of the map. In ARC/INFO, because of the creation of topology, the errors in closure and labeling for the entire map, or sections, are quickly shown onscreen by a single command. The line at arrow 3 is a fault; the rock unit on either side is the same and the map is correct in this case. As the geologic unit on each is the same, in ARC/INFO no label error would be generated, assuming the unit was only labeled once. Upon merging with the adjoining map sheet, it may be discovered that the contact at arrow 4 is not correctly continued across the boundary. Correction requires redigitizing on the individual map sheets and merging the maps again or plotting the new joined map and using it as a new digitizing base to redigitize the line(s). The Port Moller project required the merging of more than 40 individual map sheets, and error correction was tedious. Transfer of the digitized data to ARC/INFO simplified this process greatly because of its ability to edit line coordinates and move lines.

\section{Strengths and Limitations of GSMAP}

GSMAP was a major aid in the production of review copies of the Port Moller geologic map. The program's ability to allow easy digitizing of geologic data 
Table 1. Characteristics and comparison of geologic map production programs, GSMAP and ARC/INFO

\begin{tabular}{|c|c|c|}
\hline Characteristic & GSMAP' & ARC/INFO \\
\hline $\begin{array}{l}\text { DATA ENTRY FORM: } \\
\text {-Digitizer }\end{array}$ & Yes, with easy coding. & $\begin{array}{l}\text { Yes, though simultaneous entry of coding } \\
\text { is complex. }\end{array}$ \\
\hline $\begin{array}{l}\text {-File with coordinates } \\
\text {-On screen } \\
\text {-From keyboard }\end{array}$ & $\begin{array}{l}\text { Yes, indirectly. } \\
\text { No. } \\
\text { No. }\end{array}$ & $\begin{array}{l}\text { Yes. } \\
\text { Yes. } \\
\text { Yes. }\end{array}$ \\
\hline
\end{tabular}

\section{EDITING:}

-General ease of editing

$$
\begin{aligned}
& \text {-Moving features: } \\
& \text {-Lines } \\
& \text {-Points and labels } \\
& \text {-Polygons (areas) }
\end{aligned}
$$
-Easy identification of features to
edit

- Changing coding of features

- Changing unit symbols or colors

-Area calculations

-Map projection changes

LEARNING EASE:

-Manuals

-Flexibility

APPLICABILITY TO GEOLOGIC MAPS:
Inconvenient, often only through convoluted path that includes redigitizing.

Only through redigitizing.

Only through redigitizing.

Only through redigitizing of associated lines and polygon boundaries.

Through plotter output or through hit-ormiss search.

Yes, once a single feature is identified, then it or all features with that "line" code can be changed.

Text labels can be changed in text editor on separate file, colors changed in another text file. Colors are limited to 16 colors on-screen, dependent on display, no available patterns.

Only in coded polygons and only for all polygons of that code.

At plot time, all data stored in degrees.

Good, though not always intuitive, hours of effort involved.

Marginal, lacks examples and organization.

Moderate.

Excellent, tailored to them.
Fast and interactive, generally intuitive.

Yes, interactively.

Yes, interactively.

Yes, automatic as bounding line is moved.

Picked on screen with cursor, through search of data base for matching characteristics, or through plotter output.

Yes, multiple means to change single or group coding interactively on-screen through data base, or with batch processing.

Text labels can be changed in text editor on separate file, colors changed in another text file. Colors are dependent on output device, up to 256 choices, many choices of patterns can be created in pattern editor.

All polygons, inherent in creation of topology.

At anytime, data stored in units of projection (degrees, meters, and so on).

Poor, software is complex though experienced users can create a simple interface for others. Days to weeks of learning effort with training.

Good, though many volumes and hundreds of pages.

Overly so at times.

Good to excellent, needs tailoring.

${ }^{1}$ Modifications made by author to the program GSMAP to facilitate its use and reflected in above include: global search and replacement of the coding for lines, combination of the "delete line" and "recover line" routines into a single routine, support for onscreen color and higher resolution graphics display adapters, various other enhancements to the graphical interface of the program, simplified procedures to start the program, control of the scrolling of listings so that the computer pauses upon filling the screen, elimination of the need for map projection files for most uses, simplification of the plotting process, changes to the file merging procedures, and file indexing. A number of these changes were incorporated in GSMAP, version 4 (Selner and Taylor, 1987). 
on inexpensive computer hardware is an advantage. Once over a few learning hurdles, it is easy to learn to use and to be productive with the program. Its ability to change map projection and scale is extremely useful when compiling data from multiple sources at different scales and map projections. Finally, the availability of the source code in a simple and common programming language is a strength as it allows easy modification of the program by relatively inexperienced programmer users.

GSMAP's strengths only partially offset its weaknesses. The inability to do onscreen editing, as discussed, and to display lettering or other symbology onscreen proved to be a real detriment to map composition. GSMAP's editing capability is limited to changing the parameters associated with a line, or deleting the entire line and redigitizing. Adjusting the coordinates for a line is not possible, which makes correction of digitizing errors, or evaluation of "what if" scenarios, difficult.

Though GSMAP has the capability to do pattern and solid fills (coloring) of areas on a map, the procedure is awkward on a complex map. It was found to be quicker and more accurate to plot draft copies of maps and color

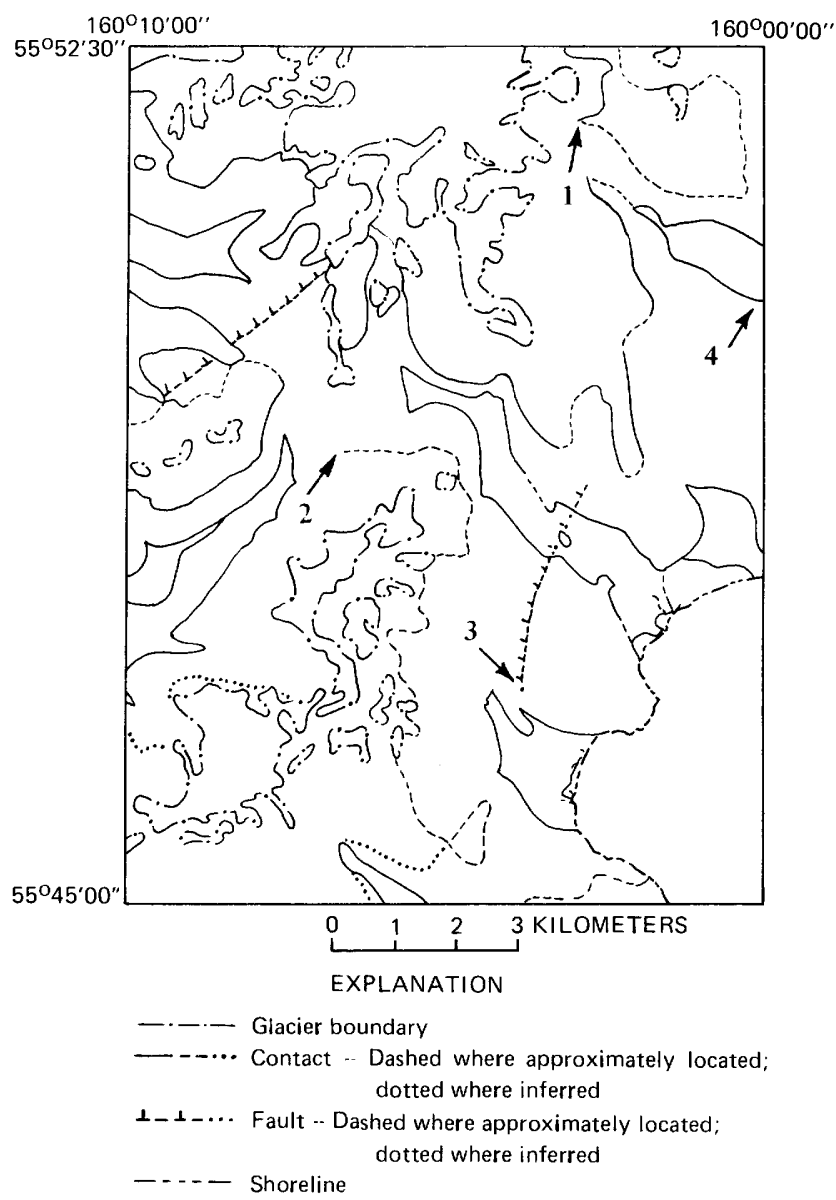

Figure 2. Portion of draft geologic map produced in GSMAP. Copy was hand colored for technical review. Arrows show types of digitizing errors discussed in text. See figure 1 for location of map area. these by hand. Color or pattern fills in GSMAP require the complete redigitizing of boundaries of the areas to be filled. During the redigitizing process when the already digitized boundary of an area is not exactly followed, a sliver (fig. 3) is produced by mistaken inclusion or exclusion of an area to be colored. The potential for producing slivers or the undesired filling of nested areas is significant. The correction of these problems is compounded by the inability to edit the line coordinates. Thus, redigitizing lines does not lessen the potential to suffer the same or similar problems again. The probability for these types of errors increases with the complexity of area boundaries, such as irregular coastlines. If polygons had been digitized for color fill, the boundaries of these closed polygons will overlie the boundaries of the polygons created from standard lines in GSMAP. If transferred to ARC/INFO, the overlap may create sliver polygons during creation of topology and will create duplicate lines.

A third limitation of GSMAP is its inability to produce quality output to any device other than a Hewlett-Packard-compatible pen plotter. Plotting of an uncolored copy of the Port Moller AMRAP geologic map for editing required two and a half to three hours, far too long for the production of a quick draft for editing. By design, GSMAP makes it easiest to identify a feature for editing by plotting the map first in hard copy in a draft mode, which also plots the identifying numbers for features. This is a tedious process on a complex map. The same map requires only 15 to 30 seconds to display on a CRT screen, hence our desire to be able to do as much editing onscreen as possible. The Hewlett-Packard plotter is capable of producing inked output on mylar, which is adequate for the publication of black and white maps. For maps that are to be published in color, however, GSMAP cannot easily produce data files that include color coding for direct transfer to other computer-based production processes.

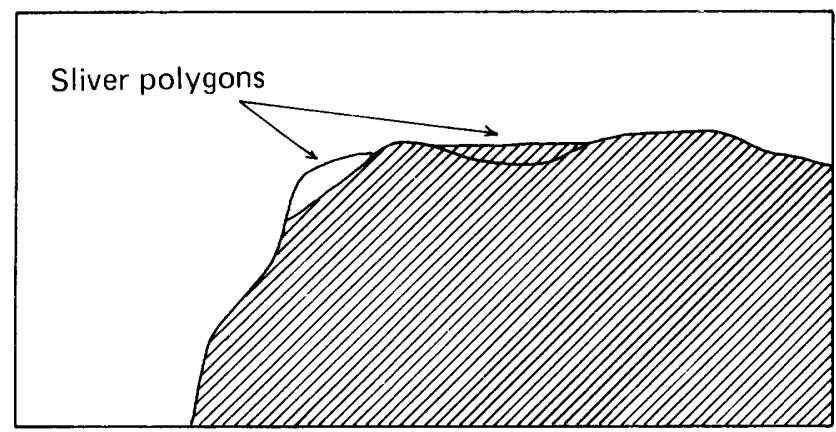

Figure 3. Sliver polygons produced by digitizing errors. Small uncolored polygon created if second digitizing to fill polygon misses part of boundary. Small filled polygon created if digitizing to fill polygon overshoots boundary. 


\section{TRANSFER TO ARC/INFO}

The Port Moller geologic data were transferred from GSMAP to ARC/INFO as individual 1:63,360 map sheets. This kept the editing task to a manageable size for each section and maintained the data resolution necessary to allow publication of selected sheets at this scale. A program (G.I. Selner, unpub. program, 1987; modified by F.H. Wilson) was used to convert GSMAP files to a format for ARC/INFO. The data are transferred in geographic coordinates (decimal seconds). An alternative program (Green and Selner, 1988) can be used on GSMAP version 5 data. Because ARC/INFO uses the distance between entities to determine the action of a number of functions, the coordinates must be changed to a rectangular system. For example, the number units defining the distance between two points varies with direction if geographic coordinates are used; it is a constant in a rectangular coordinate system. Upon transfer, the geographic coordinates were converted to UTM meters, an initial topology established, and data bases that describe each arc and polygon created. These data bases contain information on the length of lines and the area of polygons, derived from the establishment of topology. Also added to these data bases is the geologic unit a polygon represents and whether a line is a fault, fold axis, or stratigraphic contact.

Topology is important to establish because it joins line segments into polygons and therefore facilitates not only the coloring or shading of polygons but also the spatial analysis of data. Establishment of topology also facilitates nearest neighbor spatial analysis (F.H. Wilson, E.F. Binnian, and W.H. White, unpub. data, 1988).

The newest version of GSMAP (version 5.0, Selner and Taylor, 1988) has modified the data file structure by addition of node files to facilitate the establishment of topology in programs like ARC/INFO. However, the changes to GSMAP result in loss of efficiency and speed in running GSMAP. Also, if significant editing of the map file or if multiple maps have been merged in GSMAP, the node files are of little value.

\section{USE OF ARC/INFO}

\section{Editing and Conversion}

Once the Port Moller data were in ARC/INFO, editing was necessary to assist in the correct establishment of topology. GSMAP does not require that lines (arcs to ARC/INFO) meet exactly or that areas of uniform geology be closed polygons. As a result, upon transfer to ARC/INFO, a number of lines did not close polygons as they should. The editing process for the maps required the addition of polygon labels and the moving of nodes to be certain that all polygons closed. This was done in an iterative process until all topologic errors were resolved. Polygon labels can be digitized and transferred from GSMAP. Alternatively, ARC/INFO can automatically create the labels, however, the topology must be correctly established, with no sliver polygons and unclosed polygons. The choice to add labels interactively was a primitive, but effective solution that caught errors resulting from sliver and unclosed polygons.

After all maps were topologically structured and all arc and polygon attributes added, merging of the digital 1:63,360 map sheets into a single map was started. A series of arcs bounding each map sheet, equivalent to a neat line, had a unique arc attribute and was easily removed after joining sheets. Simple manual editing removed extra polygon labels and joined continuous arcs across the quadrangle boundaries. A few boundary problems, commonly known as quadrangle faults, were discovered in the process and were resolved at this time. A more subtle type of error occurred where an arc attribute changed across a quadrangle boundary, for example from a fault to a stratigraphic contact. Some of these problems resulted from digitizing errors, some were compilation errors, and others reflected the geologic uncertainty inherent in a regional mapping project. ARC/INFO has an automated procedure to aid in the process of joining adjacent maps; however, to function correctly, it requires that polygon and arc coordinates and attributes match across the boundaries. This was not possible with our data.

\section{Digitizing in ARC/INFO}

Following the Port Moller project, we used ARC/INFO to digitize the Mount Katmai AMRAP geologic map (Riehle and others, 1987). Several important differences between GSMAP and ARC/INFO were noted, and we found GSMAP to be preferable for the initial digitizing of geologic maps. The most important difference was that the type of line being digitized is required input during digitizing using GSMAP, whereas this information is added after digitizing and creation of topology in ARC/INFO. Thus, a boundary, such as a coastline, digitized in GSMAP as a single line, can yield multiple lines in ARC/INFO. During the creation of topology, ARC/INFO splits arcs at each intersection, each having a unique identifier and needing individual attribute coding. It is a daunting task to locate and code all of these arcs on a complex map. However, once initial digitizing is complete, transfer of the data to ARC/INFO facilitates editing. A collection of programs to facilitate the digitizing and coding process in ARC/INFO is being developed by T.T. Fitzgibbon (USGS, oral commun., 1989). 


\section{Strengths and Limitations of ARC/INFO for Geologic Maps}

Comparison of GSMAP and ARC/INFO (table 1) showed that for many purposes, ARC/INFO has a stronger AM capability than GSMAP. It was this stronger AM capability, in combination with ARC/INFO's analysis capability, that led us to change to it for the production and compilation of the Port Moller geologic map. In addition, ARC/INFO's analysis capability strongly enhances the analysis of spatial data and, in particular, facilitates the "what if" investigation of scenarios with spatially located data. The analytical capability of ARC/INFO allows the combination of multiple and varied types of data, which is desirable in a multidisciplinary project.

Among the improved AM features of ARC/INFO (see table 1) are onscreen display and editing of lines, points, areas (polygons), and lettering. Selection of the area of the map to be viewed, or window, is much more flexible, and a plotter is not as necessary to use or edit data. ARC/INFO also has the ability to produce output on Scitex-compatible tapes for publication. Alternatively, it can produce color separations for photographic systems of publication. Finally, ARC/INFO, longestablished and well-tested software with a large support staff, is more stable than the rapidly evolving and changing GSMAP.

Cartographic aspects of map composition can be easily controlled in the ARCPLOT module of ARC/INFO. Selection of typeface, placement, and size for lettering is interactive and visible on screen. Map legends can be created automatically, though changes of type font, such as the use of italics for fossil names within running text, is difficult. Colors and patterns are limited only by the output or display device, of which many types are supported. Selection of the window to edit, view, or plot of a map is simple, and zooming in on portions of the selected window for detailed editing is extremely rapid. It is expected that each of these features will be of significant help in the final production of the Port Moller map.

The lack of a prepared symbology for geologic maps is one weakness of ARC/INFO. The user must develop the patterns to be used for particular specialized line types, such as thrust faults, fold axes, and attitude symbols. A standard set of patterns for special geologic symbology are being created (S.J. Moll, written commun., USGS EROS Data Center, 1988). In addition to developing geologic line symbology, techniques to digitize and plot correctly rotated attitudes must be developed by the user. A technique is under development by R.W. Lietzow (oral commun., USGS EROS Data Center, 1988) to allow digitizing the end points of an attitude symbol and then calculate the strike and add it to the map data base; this technique will also allow input of the dip at the same time. Attitude data for the Port Moller area already existed in a data base with location and strike and dip, and therefore the digitizing phase did not present a problem; adding these data to the map data base was simple. It should be noted that the problem of digitizing attitudes exists for GSMAP; however, that program has very simple and effective procedures for plotting the attitudes once digitized.

In comparison to GSMAP, a significant consideration is that ARC/INFO is a commercial package and has an acquisition cost. ARC/INFO is primarily a minicomputer program but also has been released in a microcomputer version.

\section{CONCLUSIONS: THINGS LEARNED FROM THE PROCESS}

ARC/INFO makes available a rich variety of editing and analysis capabilities compared to GSMAP. Unfortunately, these capabilities add a level of complexity that make it difficult for the part-time user to even realize the range of choices available. Whereas GSMAP was developed strictly for the digitizing and publication of geologic maps, ARC/INFO is a multipurpose GIS system with extended map editing functions, an attached data base, and powerful analytical tools. GSMAP can be used with a few hours training, and any particular version can be mastered in a short time. Mastery of ARC/INFO is long-term process; ARC/INFO can be overwhelming to the novice without training and technical support for custom programming. Yet despite this, ARC/INFO is so potentially useful in map editing, compilation, and analysis that some effort is warranted to learn its use. A preliminary version of more user-supportive interface for ARC/INFO that greatly simplifies its use has been developed by T.T. Fitzgibbon and C.M. Wentworth (oral and written commun., 1988, 1989).

Meeting our goal of rapidly preparing a geologic map for review and publication was more complex than anticipated because we were one of the first to use the described systems for this purpose. GSMAP was a new and untried tool, and ARC/INFO was an unfamiliar tool. However, because of the development that has been done on both, this goal can now be met by the systems used in the Port Moller project. Both systems accelerate the drafting and revision part of map preparation. They also enhance the compilation phase with simple scale change capabilities and onscreen display. These systems do not, however, eliminate the need for critical examination of the data, nor do they shorten the time it takes for authors, reviewers, and editors to critically examine the product to create a quality geologic map.

Possibly the most important long-term gain from the transfer of our geologic data from GSMAP to ARC/INFO is the analytical capability gained by having information in a spatial data base. Fossil locality data, 
geochemical analyses, geophysical data, and other types of spatially coded data transferred into ARC/INFO allow rapid comparison and combination of disparate data types. Fossil determinations can be compared with geologic map units to point out areas of conflict, either from incorrect fossil locations, suspect determinations, or errors in the geologic map. Geochemical data can be retroactively coded for geologic unit and data selected for statistical analyses from single or related units. Drainage basins can be analyzed to yield the proportion of each geologic unit in the basin, and using statistical data on background concentrations of elements, the contribution of each rock unit can be estimated. Each of these, and other possibilities, enhance the geological scientist's ability to develop answers to questions of interest that were previously difficult or impossible to obtain.

It is reasonable to ask the question, was the process worthwhile? Was all the effort expended digitizing the Port Moller map a savings over a traditional, manually drafted and produced map? Those questions are answered on two levels. If the goal is to simply produce a geologic map, the answer must be a qualified yes. The easy scale change capability and the elimination of some types of errors with the onscreen editing that is possible, even that available with GSMAP, greatly facilitate map compilation. However, it is not certain that once the above part of the map production process is complete, that hand redrafting of computer-produced copy might not be a faster route to a finished map. If the goal, however, is to produce a publishable map and also use and analyze the digital geologic data in other ways, then the answer is an unqualified yes.

\section{REFERENCES CITED}

Atwood, W.W., 1911, Geology and mineral resources of parts of the Alaska Peninsula: U.S. Geological Survey Bulletin 467, 137p.

Burk, C.A., 1965, Geology of the Alaska Peninsula - island arc and continental margin: Geological Society of America Memoir 99, 250 p., scales 1:250,000 and 1:500,000, 3 sheets.

du Bray, E.A., Hurtubise, D.O., and Bannister, C.A., 1987, Geologic map of the Weepah Spring Wilderness study area, Lincoln and Nye counties, Nevada: U.S. Geological Survey Miscellaneous Field Studies Map MF-1922, 1 sheet, scale 1:50,000.
Environmental System Research Institute, 1987, Users Guide, ARC/INFO, The Geographic Information System Software: Redlands, Calif., Environmental System Research Institute, not consecutively paginated. (Proprietary software manual)

Green, G.N., and Selner, G.I., 1988, GSMARC: A program and procedure to convert GSMAP databases into ARC/INFO coverages, GSDARC: A counterpart program for GSDRAW data bases and an ARC/INFO procedure to topologically structure resultant data: U.S. Geological Survey Open-File Report 88-430, 16 p., 1 (5 1/4") floppy disk.

Kennedy, G.C., and Waldron, H.H., 1955, Geology of Pavlof Volcano and vicinity, Alaska: U.S. Geological Survey Bulletin 1028-A, 19 p., scale 1:100,000.

Moore, J.C., 1974, Geologic and structural map of part of the Outer Shumagin Islands, southwestern Alaska: U.S. Geological Survey Miscellaneous Investigations Series Map I-815, scale 1:63,360.

Riehle, J.R., Detterman, R.L., Yount, M.E., and Miller, J.W., 1987, Preliminary geologic map of the Mt. Katmai quadrangle and portions of the Afognak and Naknek quadrangles, Alaska: U.S. Geological Survey Open-File Report 87-593, 1 sheet, scale 1:250,000.

Selner, G.I., and Taylor, R.B., 1987, GSDRAW and GSMAP version 4.0: Prototype programs for the IBM PC or compatible microcomputers to assist compilation and publication of geologic maps and illustrations: U.S. Geological Survey Open-File Report 87-496a, 90 p.

1988, GSDRAW and GSMAP version 5.0: Prototype programs, level 5, for the IBM PC and compatible microcomputers, to assist compilation and publication of geologic maps and illustrations: U.S. Geological Survey Open-File Report 88-295a, 130 p.

Selner, G.I., Taylor, R.B., and Johnson, B.R., 1986a, GSDRAW and GSMAP: Prototype programs for the IBM PC or compatible microcomputers to assist compilation and publication of geologic maps and illustrations: U.S. Geological Survey Open-File Report 86-42, 40 p. and 1 (5 1/4") disk.

1986b, GSDRAW and GSMAP version 3.0: Prototype programs for the IBM PC or compatible microcomputers to assist compilation and publication of geologic maps and illustrations: U.S. Geological Survey Open-File Report $86-447,53 \mathrm{p}$. and 1 (5 1/4") disk.

\section{Reviewers:}

Richard Koch Donald Richter 


\title{
Petrographic and Chemical Description of the Variably Deformed Speel River Pluton, South of Juneau, Southeastern Alaska
}

\author{
By James L. Drinkwater, David A. Brew, and Arthur B. Ford
}

\begin{abstract}
The Speel River pluton, south of Juneau, Alaska, is a synkinematically emplaced sill of Paleocene age. It is part of the tonalite sill belt of Late Cretaceous to early Tertiary age that extends more than $700 \mathrm{~km}$ in the western part of the Coast plutonic-metamorphic complex of southeastern Alas$\mathrm{ka}$. The main part of the pluton is medium- to coarsegrained, well-foliated, sphene-bearing biotite-hornblende tonalite. Composition and texture vary, particularly toward the lower margin, which consists of more highly foliated and sphene-rich hornblende-biotite quartz diorite, and toward the upper margin of sphene-biotite-hornblende quartz monzodiorite and quartz diorite.

The calc-alkaline pluton is chemically similar to other plutons in the sill belt, although silica-variation diagrams show some contrast. Decreasing $\mathrm{MgO}$ and $\mathrm{FeO}^{*}$ with increasing $\mathrm{SiO}_{2}$ are the most distinctive variations over the 59 to 66 percent $\mathrm{SiO}_{2}$ range of the pluton. Rare-earth-element (REE) patterns show light-REE enrichment and increased light/heavy $\mathrm{REE}$ fractionation with $\mathrm{SiO}_{2}$ content and are generally similar to other sill belt plutons. Tightly grouped REE patterns and the generally homogeneous modal, mineralogic, and major-element compositions indicate that the pluton crystallized as a single cooling unit from an evolved magma of restricted compositional range. This pattern appears to be typical of the plutons in the sill belt.
\end{abstract}

\section{INTRODUCTION}

The Speel River pluton is a 6- to 7-kilometer-wide tonalitic sill that extends from just south of Taku Inlet southward to beyond Endicott Arm (fig. 1). The pluton was mapped and informally named the Speel River pluton by Brew and Ford (1986), who correlated it with plutons in the Coast complex sill belt (Brew and Morrell, 1983) that are now collectively known as the great tonalite sill (Brew, 1988). Miller (1962) examined part of the pluton around Crater and Long lakes and referred to it as a quartz diorite intrusion. Brew and Grybeck (1984) referred to Miller's localities and those farther to the south as the Speel River-Fords Terror pluton.
The great tonalite sill (fig. 1) is a long and narrow northwest-southeast-trending belt of eastward dipping orthogneiss sheets of Late Cretaceous to early Tertiary age. The belt forms the western part of the central zone of the informally named Coast plutonic-metamorphic complex (Brew and Ford, 1984a and b) for over 700 kilometers in southeastern Alaska (Brew, 1988; Brew and Ford, 1981, 1984b; Brew and Grybeck, 1984; Brew and Morrell, 1983). Foliation in these concordant plutons parallels the northwest trend of the regional metamorphic fabric of their country rocks, as well as the intrusive contacts. The sill belt represents intrusion either near a major suture between tectonostratigraphic terranes (Brew and Ford, 1981; Monger and others, 1982) or between the two sides of a closed-up within-plate rift (Brew and Ford, 1983). The Coast Range megalineament (Brew and Ford, 1978) is generally within a few kilometers of the southwest side of the great tonalite sill. The megalineament is a large, regional structuraltopographic feature that, at depth, probably is the boundary between the dominant granitic terrane to the east and the metamorphic terrane to the west.

This report describes the petrographic and chemical characteristics of the northern part of the Speel River pluton, as far south as Whiting River (fig. 2). The data bear on the petrogenesis and emplacement history of the pluton, and to a lesser extent, on the metamorphic character of the pluton and its country rocks. The Speel River pluton is representative of other bodies in the sill belt in composition, chemistry, and age and in recording varying degrees of deformation and metamorphism. Because of this, the data also bear on the character and origin of the tonalite sill as a whole.

\section{DESCRIPTION OF THE SPEEL RIVER PLUTON}

The Speel River pluton separates greenschist- and amphibolite-grade schist of Mesozoic to early Tertiary metamorphic age, on the west, from migmatitic and nonmigmatitic gneiss of similar age and granitic rocks of 
Eocene age to the east (fig. 2). It has fairly sharp contacts with some small apophyses and digitations. The foliation in the pluton is defined by aligned mafic-mineral grains and by local crude compositional layering; the folia parallel that in the northwest-striking and northeastdipping metamorphic country rock. The hornblende is typically aligned within folia marked by abundant hornblende and biotite. The lineations in the pluton are defined by poorly to well aligned hornblende grains that parallel mineral lineations in the adjacent country rock.
The origin of the strong directional fabric of the Speel River and other plutons of the sill belt is attributed by Brew and Ford (1981) and Brew and others (1989) to synkinematic emplacement during a later phase of a major deformational-metamorphic event. This strong fabric is absent in some central parts of the pluton. In those parts, a conspicuous magmatic flow foliation varies locally in strike but is generally consistent with the attitude of the strong deformational fabric. These same parts contain synplutonic dikes that show varying degrees

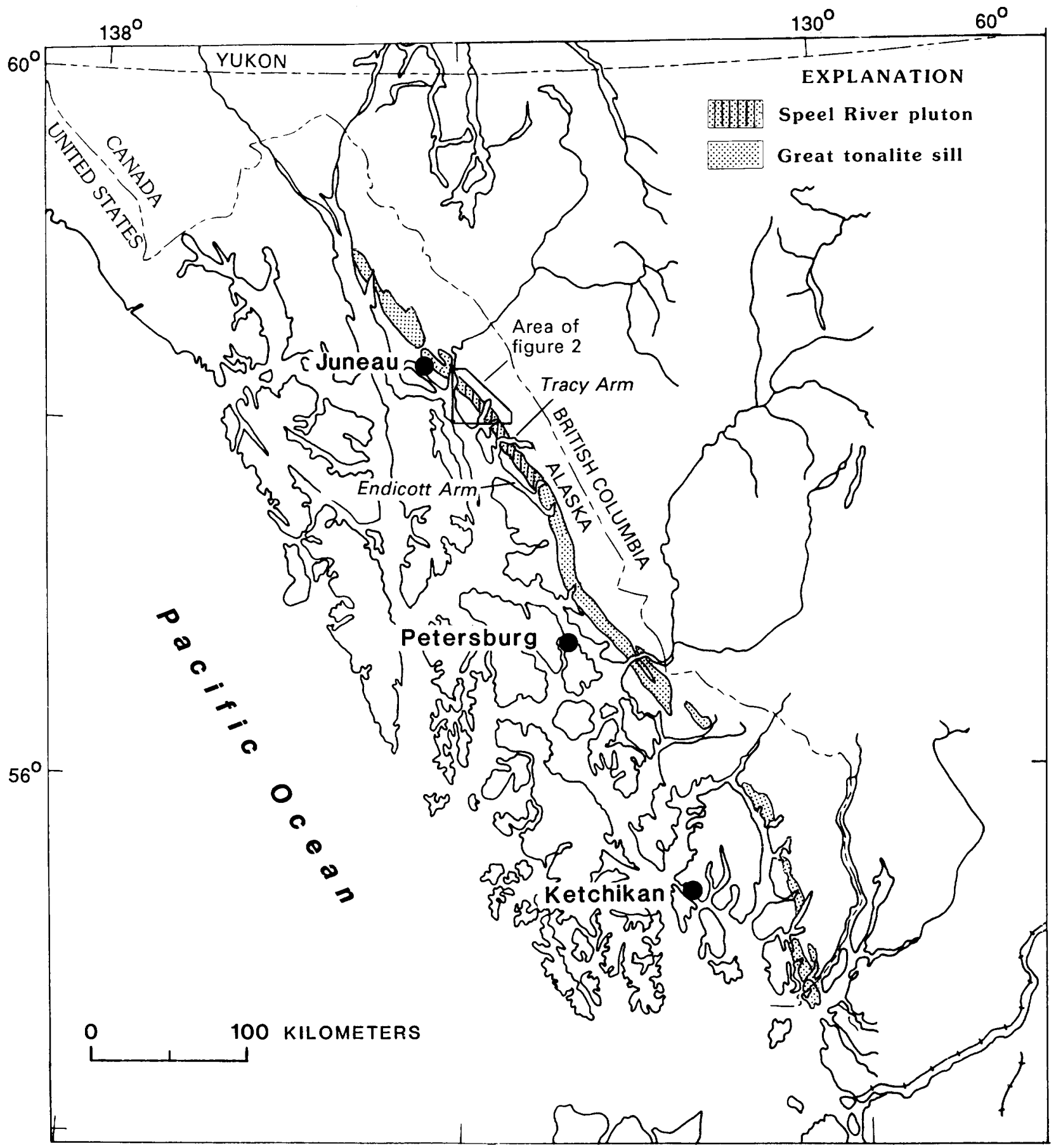

Figure 1. Index map showing locations of Speel River pluton and great tonalite sill in relation to southeastern Alaska. 
of disruption, separation, and attenuation ranging from coherent bodies to separated inclusions. A few undeformed pockets of rounded mafic inclusions are also present. These original magmatic features indicate that the strong fabric was not imposed everywhere during emplacement of the pluton.

The main body of the Speel River pluton is medium- to coarse-grained equigranular tonalite (fig. 3) in which hornblende is generally more abundant than biotite. Modes of 20 samples distributed widely through the pluton were determined by point-counting rock slabs stained for K-feldspar and plagioclase using the method of Norman (1974). Color index ranges from 10 to 36 and averages 22 .

Composition and texture vary locally in the pluton, especially near its intrusive margins, where quartzfeldspar ratios generally decrease (fig. 3). Mafic-mineral content in main-phase rocks increases across the pluton from 10 to 22 percent in the northeastern half to 22 to 36 percent in the southwestern half. Border-phase rocks are generally finer grained and contain more sphene than main-phase tonalite. Rocks of the more intensely deformed and metamorphosed lower border zone are strongly foliated to gneissic, locally porphyroblastic,

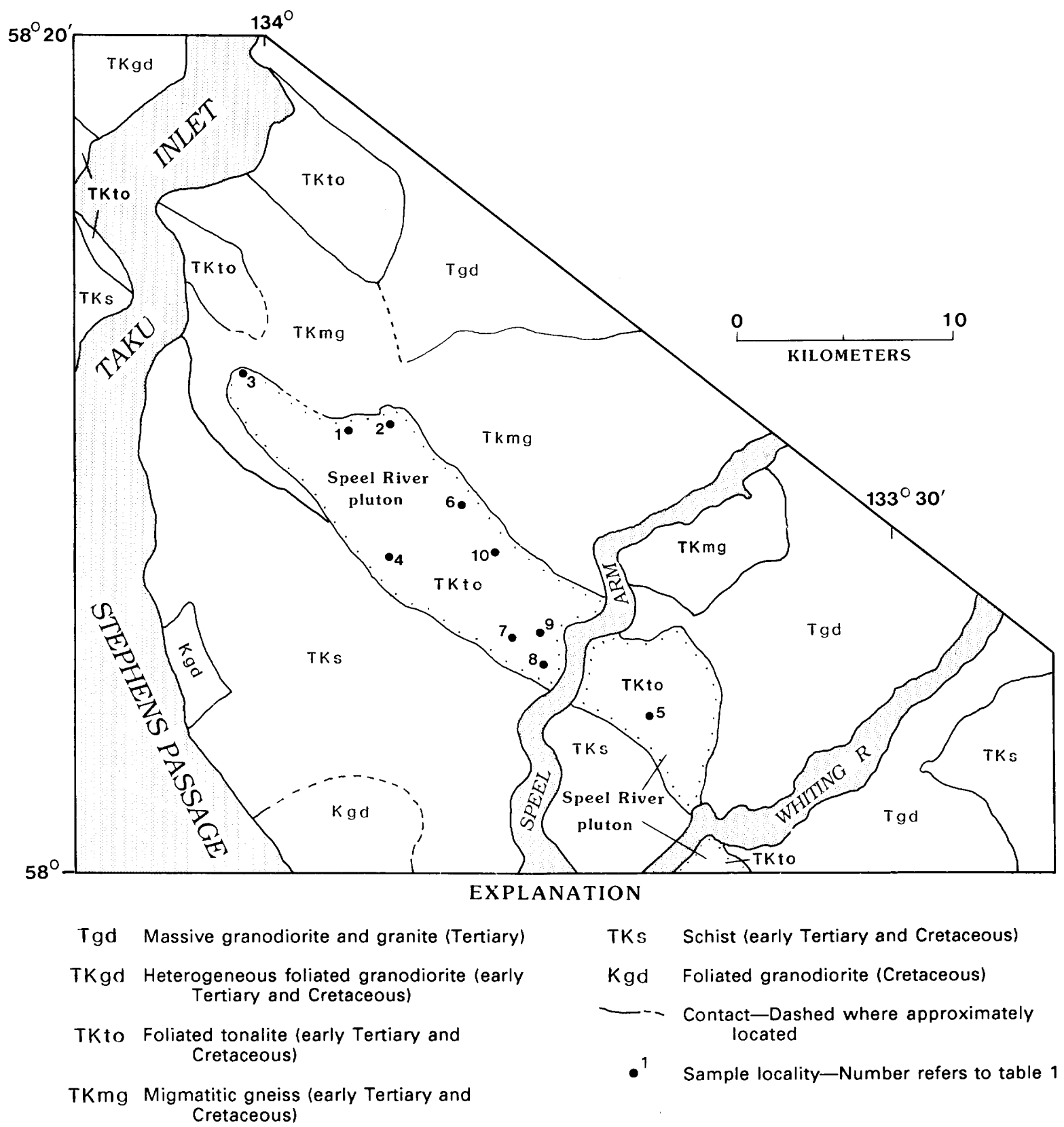

Figure 2. Generalized geologic map of area around northern part of Speel River pluton. Location of chemically analyzed samples shown by numbered dots. See figure 1 for location of area. 
sphene-bearing hornblende-biotite quartz diorite. Less deformed rocks of the upper border phase are weakly foliated, porphyritic to seriate, sphene-bearing biotitehornblende quartz monzodiorite or quartz diorite.

Swarms of mafic inclusions are locally common, and elongate inclusions and schlieren in the border phase are aligned parallel to intrusive contacts and regional foliation. Leucocratic fine- to medium-grained granodiorite occurs as sill-like segregations in the pluton. Undeformed felsic dikes are common and range in composition from granite to quartz monzodiorite (fig. 3). Mafic dikes are less abundant and are disrupted.

\section{Petrography}

The major minerals of the Speel River pluton are plagioclase, hornblende, quartz, biotite, and K-feldspar. Plagioclase forms 54 to 70 percent of most samples and occurs as subhedral, subequant to augen-shaped grains that exhibit weak to moderately strong multiple normal or oscillatory normal zoning of magmatic origin. Plagioclase composition, as determined optically by the MichelLevy method, ranges from $\mathrm{An}_{31}$ to $\mathrm{An}_{45}$ and averages $\mathrm{An}_{40}$. Secondary sericite and epidote group minerals occur along cracks and cleavages and as patches in plagioclase. Apatite, zircon, and magnetite are uncommon inclusions in the plagioclase.
Quartz makes up 14 to 30 percent of most samples; it occurs chiefly as interstitial strained aggregates and as medium-grained anhedral subequant to elongate and stretched grains. In more deformed rocks, it occurs as mosaics of strained and unstrained interlocking subgrains with rare polygonal development.

$\mathrm{K}$-feldspar is a minor component (less than 8 percent) of most samples and occurs as fine-grained interstitial grains and less commonly as coarser poikilitic grains. It is generally microperthitic and strained.

Hornblende, biotite, and minor opaque minerals form 10 to 36 percent of the samples. Hornblende is subhedral, generally fresh to partly altered (to epidote and opaque minerals), typically embayed and partly resorbed; commonly contains inclusions of apatite, zircon, and magnetite; and is pleochroic light brown to brownish green to green. Brown to reddish-brown pleochroic biotite occurs as platy and lamellar grains, which are partly altered to chlorite, sphene, opaques, and prehnite. Inclusions of apatite and zircon are common in biotite. Secondary epidote occurs mostly as granular aggregates in hornblende and plagioclase, although it occurs with subhedral form within hornblende in some sections. Prehnite typically forms pods of sheaflike aggregates in biotite. Sphene, apatite, and zircon are common accessory minerals. Sphene occurs as euhedral to subhedral typically embayed or skeletal flow-aligned grains.

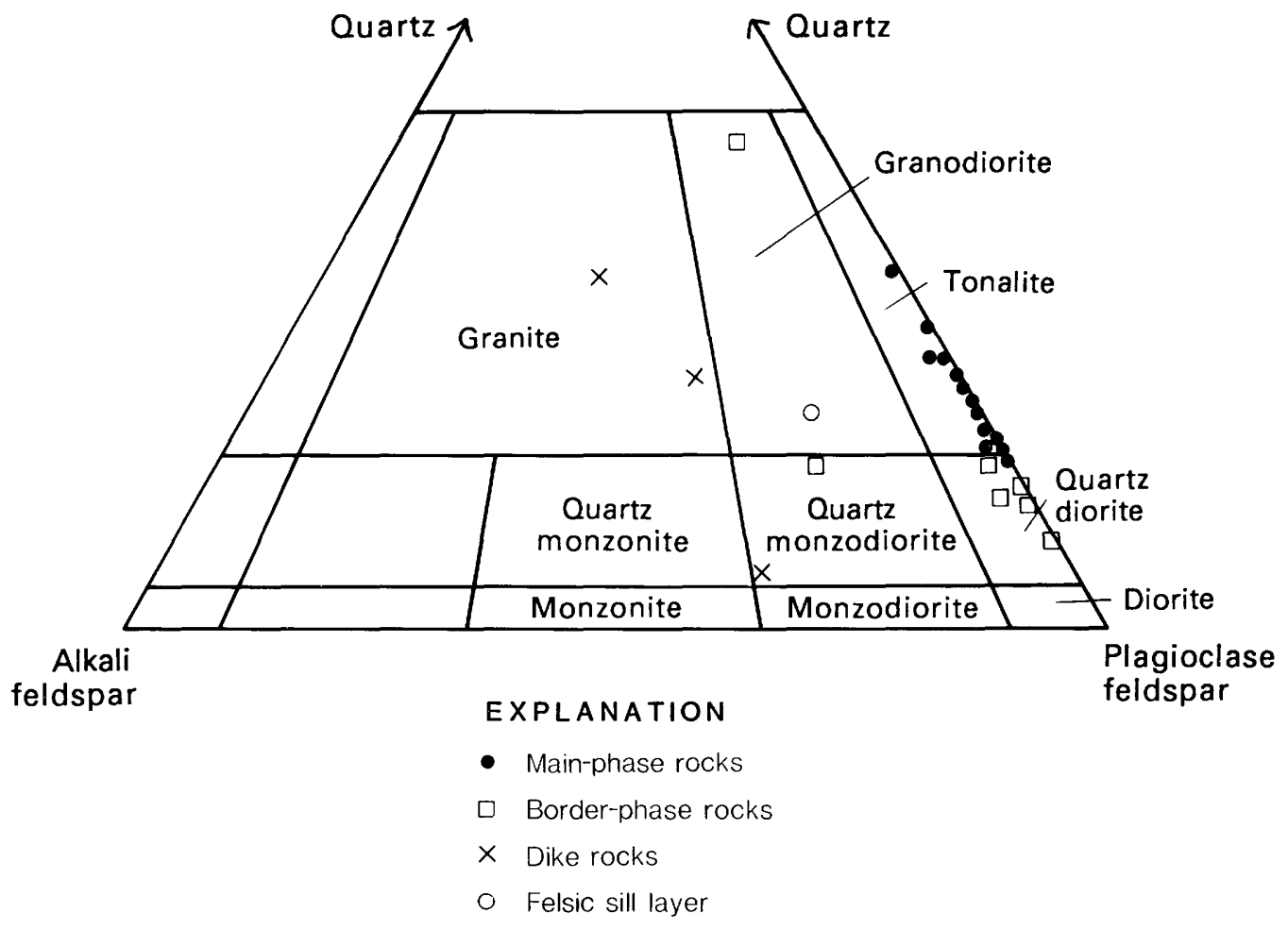

Figure 3. Modal composition of rocks from Speel River pluton plotted on Streckeisen's (1973) plutonic rock classification diagram. 
Table 1. Major-element chemistry (normalized to 100 percent volatile free) for representative samples from the Speel River pluton

[Major elements analyzed by XRF, Lakewood, Colo; analysts: R.V. Mendes, A.J. Bartel, K. Stewart, J. Taggart, and D. Siems. FeO analyzed by rock analysis, Menlo Park, Calif.; analyst: S. MacPherson; and Lakewood, Colo.; analyst: E. Brandt]

\begin{tabular}{lcccccccccc}
\hline Sample & $85 E 1$ & $85 D B$ & $85 D B$ & $82 D B$ & $85 E 1$ & $82 S K$ & $87 J S$ & $87 S K$ & $87 S K$ & $87 S K$ \\
No.' & $061 \mathrm{a}$ & $105 \mathrm{a}$ & $108 \mathrm{a}$ & $382 \mathrm{a}$ & $109 \mathrm{a}$ & $401 \mathrm{a}$ & $011 \mathrm{a}$ & $043 \mathrm{a}$ & $044 \mathrm{a}$ & $052 \mathrm{a}$ \\
& 1 & 2 & 3 & 4 & 5 & 6 & 7 & 8 & 9 & 10
\end{tabular}

\begin{tabular}{|c|c|c|c|c|c|c|c|c|c|c|}
\hline \multicolumn{11}{|c|}{ Whole rock analyses (weight percent oxide) } \\
\hline $\mathrm{SiO}_{2}$ & 58.75 & 63.08 & 61.01 & 60.50 & 60.19 & 62.79 & 60.33 & 65.75 & 63.21 & 64.64 \\
\hline $\mathrm{Al}_{2} \mathrm{O}_{3}$ & 17.92 & 17.69 & 16.43 & 17.92 & 18.52 & 17.65 & 18.52 & 17.63 & 17.80 & 17.25 \\
\hline $\mathrm{Fe}_{2}^{2} \mathrm{O}_{3}^{3}$ & 2.06 & 2.13 & 1.95 & 2.04 & 2.15 & 1.69 & 2.29 & 1.29 & 2.19 & 1.64 \\
\hline $\mathrm{FeO}^{3}$ & 4.41 & 2.81 & 4.41 & 4.06 & 3.37 & 3.56 & 3.33 & 2.15 & 2.75 & 2.68 \\
\hline $\mathrm{MgO}$ & 3.15 & 2.16 & 3.55 & 2.88 & 2.52 & 2.44 & 2.53 & 1.48 & 2.00 & 1.93 \\
\hline $\mathrm{CaO}$ & 7.46 & 5.78 & 6.19 & 5.98 & 7.23 & $5 . .48$ & 7.19 & 6.06 & 6.20 & 5.70 \\
\hline $\mathrm{Na}_{2} \mathrm{O}$ & 3.63 & 3.80 & 3.00 & 3.53 & 3.80 & 3.52 & 3.87 & 3.92 & 3.71 & 3.67 \\
\hline $\mathrm{K}_{2} \mathrm{O}$ & 1.41 & 1.68 & 2.44 & 1.95 & 1.13 & 1.88 & .97 & 1.02 & 1.35 & 1.66 \\
\hline $\mathrm{TiO}_{2}$ & .73 & .57 & .74 & .79 & .59 & .69 & .59 & .42 & .47 & .51 \\
\hline $\mathrm{P}_{2} \mathrm{O}_{5}^{2}$ & .37 & .21 & .18 & .24 & .40 & .21 & .28 & .23 & .25 & .23 \\
\hline $\mathrm{MnO}$ & .12 & .08 & .11 & .10 & .10 & .09 & .10 & .06 & .09 & .07 \\
\hline $\mathrm{LOI}^{2}$ & .58 & .57 & 1.16 & .61 & .66 & .90 & .36 & .30 & .40 & .45 \\
\hline \multicolumn{11}{|c|}{ CIPW Norms } \\
\hline Quartz & 11.51 & 18.57 & 14.86 & 14.13 & 14.72 & 18.46 & $1 ` 4.93$ & 23.68 & 20.03 & 21.41 \\
\hline Corundum & - & - & - & - & - & .38 & - & - & - & - \\
\hline Orthoclase & 8.30 & 9.92 & 14.41 & 11.49 & 6.66 & 11.09 & 5.74 & 6.05 & 7.83 & 9.84 \\
\hline Albite & 30.67 & 32.16 & 25.38 & 29.90 & 32.11 & 29.78 & 32.72 & 33.17 & 31,41 & 31.08 \\
\hline Anorthite & 28.48 & 26.25 & 24.15 & 27.30 & 30.17 & 25.78 & 30.32 & 27.48 & 28.00 & 25.67 \\
\hline Diopside & 5.03 & .85 & 4.37 & .62 & 2.48 & - & 2.83 & .86 & .90 & .90 \\
\hline Hypersthene & 10.79 & 7.59 & 12.19 & 11.53 & 8.68 & 10.26 & 8.37 & 5.57 & 7.20 & 7.22 \\
\hline Magnetite & 2.98 & 3.09 & 2.83 & 2.95 & 3.12 & 2.46 & 3.32 & 1.87 & 3.17 & 2.38 \\
\hline Ilmenite & 1.39 & 1.08 & 1.40 & 1.51 & 1.13 & 1.31 & 1.12 & .79 & .88 & .96 \\
\hline Apatite & .85 & .49 & .43 & .57 & .93 & .49 & .66 & .54 & .59 & .54 \\
\hline Sum & 100 & 100 & 100 & 100 & 100 & 100 & 100 & 100 & 100 & 100 \\
\hline
\end{tabular}

185E1061a, 82DB382a, 82SK401a, 87SK052 and -044 are sphene-bearing biotite-hornblende tonalites; 5E1109a, 85DB105a, and 87JS011a are biotite-hornblende tonalites; 87SK043a is sphene-bearing hornblende-biotite tonalite; $85 \mathrm{DB} 108 \mathrm{a}$ is sphene-bearing hornblende-biotite granodiorite.

${ }^{2} \mathrm{LOI}=\mathrm{H}_{2} \mathrm{O}$ and $\mathrm{CO}_{2}$ (loss on ignition).

Apatite occurs as tiny euhedral inclusions in other minerals and as coarser subhedral discrete grains clustered with mafic minerals.

Microscopic evidence for directed stress includes strained extinction in quartz, plagioclase, and K-feldspar; bent and kinked cleavage in biotite; disrupted twin lamellae in plagioclase; partial gradational disappearance of twin lamellae and zoning in plagioclase; and granulation of quartz. Clear and unstrained overgrowths on plagioclase may be of posttectonic origin.

\section{Chemistry}

Major-element chemical data for the Speel River pluton are summarized in table 1 . The calc-alkalic composition of the pluton is indicated by the quartz and diopside normative composition (table 1), variations on the AFM plot (fig. 4), and an alkali-lime index of less than 1 (.67 to .99). $\mathrm{Al}_{2} \mathrm{O}_{3} /\left(\mathrm{CaO} \pm \mathrm{Na}_{2} \mathrm{O} \pm \mathrm{K}_{2} \mathrm{O}\right)$ values of less than 1 (.85 to .99$)$ indicate a metaluminous composition according to Shand's (1947) classification. All but one sample plot in the tonalite field of Barker's (1979) ternary diagram of normative feldspar composition (fig. $5)$.

Major-element oxide compositions of 10 samples distributed through the main body of the Speel River pluton (table 1) are plotted on variation diagrams (fig. 6) and an AFM diagram (fig. 4). The fairly coherent but slightly scattered distribution are generally similar to those plots of rocks from other great tonalite sill bodies (Brew, 1988). However, the $\mathrm{K}_{2} \mathrm{O}$ and $\mathrm{TiO}_{2}$ versus $\mathrm{SiO}_{2}$ plots of the Speel River pluton show more scatter and irregularity than comparable plots for other tonalite sills 
(Brew, 1988), and the $\mathrm{Al}_{2} \mathrm{O}_{3}$ and $\mathrm{CaO}$ versus $\mathrm{SiO}_{2}$ plots are flatter in the Speel River pluton. These differences may be due to the more restrictive $\mathrm{SiO}_{2}$ range (59 to 66 percent) for rocks from the Speel River pluton. In that narrow range, $\mathrm{K}_{2} \mathrm{O}$ actually decreases slightly with increased $\mathrm{SiO}_{2}$, and this pattern is also present for the same range in $\mathrm{K}_{2} \mathrm{O}-\mathrm{SiO}_{2}$ plots of other tonalite sill rocks (Brew, 1988). The linear trends of decreasing $\mathrm{MgO}$ and

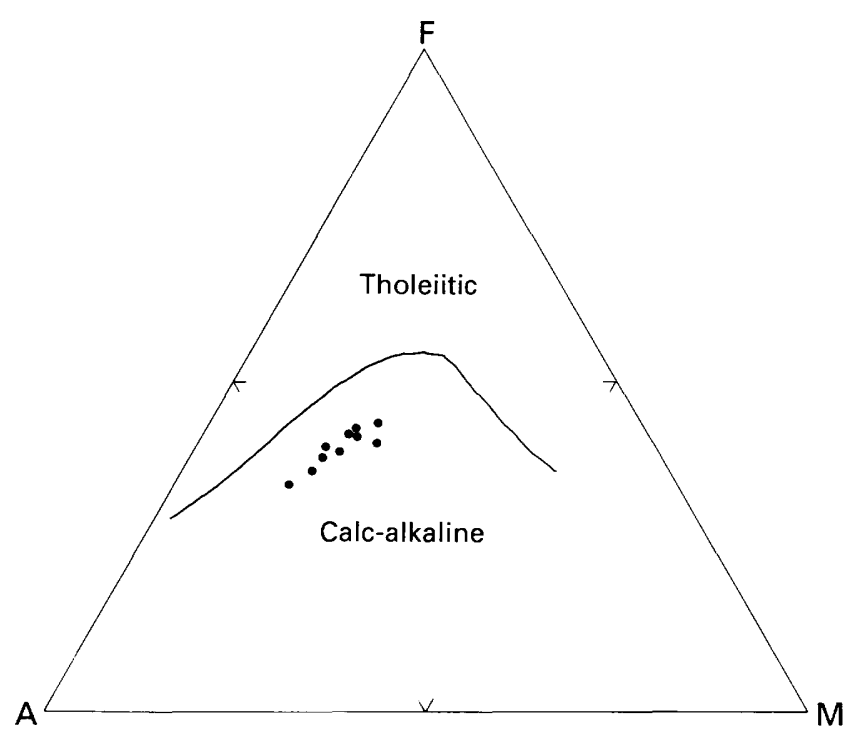

Figure 4. Ternary AFM diagram with boundary fields from Irvine and Baragar (1971) showing samples from Speel River pluton (solid dots). $\mathrm{A}$ is $\mathrm{Na}_{2} \mathrm{O}+\mathrm{K}_{2} \mathrm{O}, \mathrm{F}$ is total iron calculated from $\mathrm{FeO}$, and $\mathrm{M}$ is $\mathrm{MgO}$.

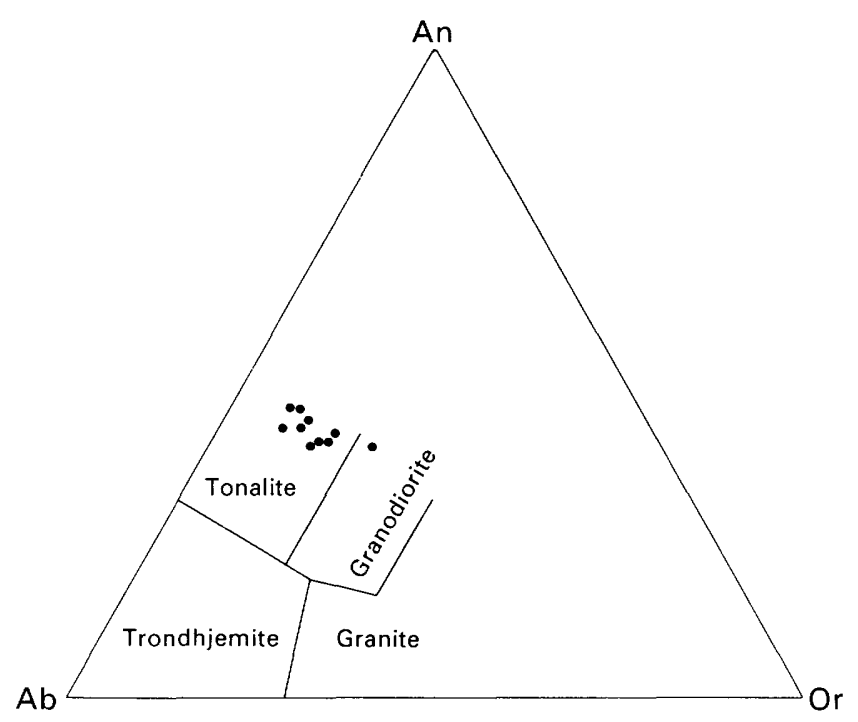

Figure 5. Ternary diagram of normative orthoclase (Or)anorthite (An)-albite (Ab) composition for rocks from Speel River pluton. Boundary fields from Barker (1979).
$\mathrm{FeO}^{*}$ with increasing $\mathrm{SiO}_{2}$ are the most distinctive major oxide variations for the Speel River pluton.

Rare-earth-element (REE) patterns of chondritenormalized abundances for the Speel River pluton (fig. 7) are similar to those from sill rocks of the Petersburg area (Brew, 1988). Light rare-earth elements are highly enriched (La 65-110 times chrondrites) compared to heavy rare-earth elements (Lu 5-8 times chrondrites), and a crossover pattern occurs between light and heavy REE, with the most silicic tonalite showing the largest light/heavy fractionation. This pattern of progressive decrease in REE with increasing silica is also evident for other tonalite sill rocks (Brew, 1988). One sample, collected from the northern border of the pluton, has a conspicuous Gd anomaly of uncertain origin. The anomaly in that sample (85DB108a) could reflect analytical error, but it may reflect assimilation of wallrock since the sample is $\mathrm{K}_{2} \mathrm{O}$ - and $\mathrm{MgO}$-rich and $\mathrm{P}_{2} \mathrm{O}_{5}$-depleted relative to the other samples (table 1 ).

No chemical analyses are available from borderphase rocks, but petrographic evidence indicates that significant variations are present. Compared with the main body of the pluton, the lower border-phase rocks have lower quartz and K-feldspar content and higher mafic mineral abundance, whereas upper border rocks contain more K-feldspar and less quartz.

\section{AGE AND GEOBAROMETRY}

Discordant K-Ar ages of $59.0 \pm 2 \mathrm{Ma}$ (hornblende) and $49.6 \pm 2 \mathrm{Ma}$ (biotite) were determined for the Speel River pluton (table 2). The hornblende age is compatible with the Late Cretaceous to early Paleocene age inferred for other plutons in the sill belt (Brew, 1988; Gehrels and others, 1984; Brew and Grybeck, 1984). The younger biotite age is probably a reset metamorphic or uplift age. A K-Ar hornblende age of $62 \mathrm{Ma}$ was reported by Brew and Ford (1987) for the Speel River-Fords Terror pluton to the south.

The Speel River pluton probably crystallized at intermediate pressure, based on the geobarometric pressure of $4.7 \mathrm{kbar}$ determined by Hollister and others (1987) on hornblende from the pluton's southern continuation near Tracy Arm, beyond the study area.

\section{DISCUSSION}

The descriptive data presented above provide the basis for further studies and interpretation and also indicate where further sampling and petrographic studies are needed. In particular, samples from the upper and lower border zones are needed to establish their mineralogical and chemical compositional relations to the main body. As presently interpreted (Brew and others, 1989), 
the deformed quartz diorite of the lower border, the well-foliated tonalitic main body, and the weakly foliated upper border reflect the effects of dynamothermal metamorphism and deformation during synkinematic emplacement of the pluton. Chemical and petrographic features along the margins may instead have resulted from contamination by assimilated country rock. In the upper part of the pluton, reaction between the margin and adjacent granitic gneiss wallrock and inclusions may explain the local enrichment of K-feldspar and sphene. Assimilation of mafic schist adjacent to the lower margin of the pluton may likewise account for local enrichment of mafic minerals and depletion of quartz-potash feldspar in rocks of the lower border zone. More subtle chemical variations, such as the northward increase along strike in $\mathrm{MgO}$ and total $\mathrm{FeO}$, may reflect original compositional change in the parental magma.

Since differentiation processes increase REE concentrations (Cox and others, 1979), the REE patterns and abundances (fig. 7) and linear trends of variation diagrams (figs. 4 and 6) suggest that the Speel River pluton was derived from a highly evolved magma
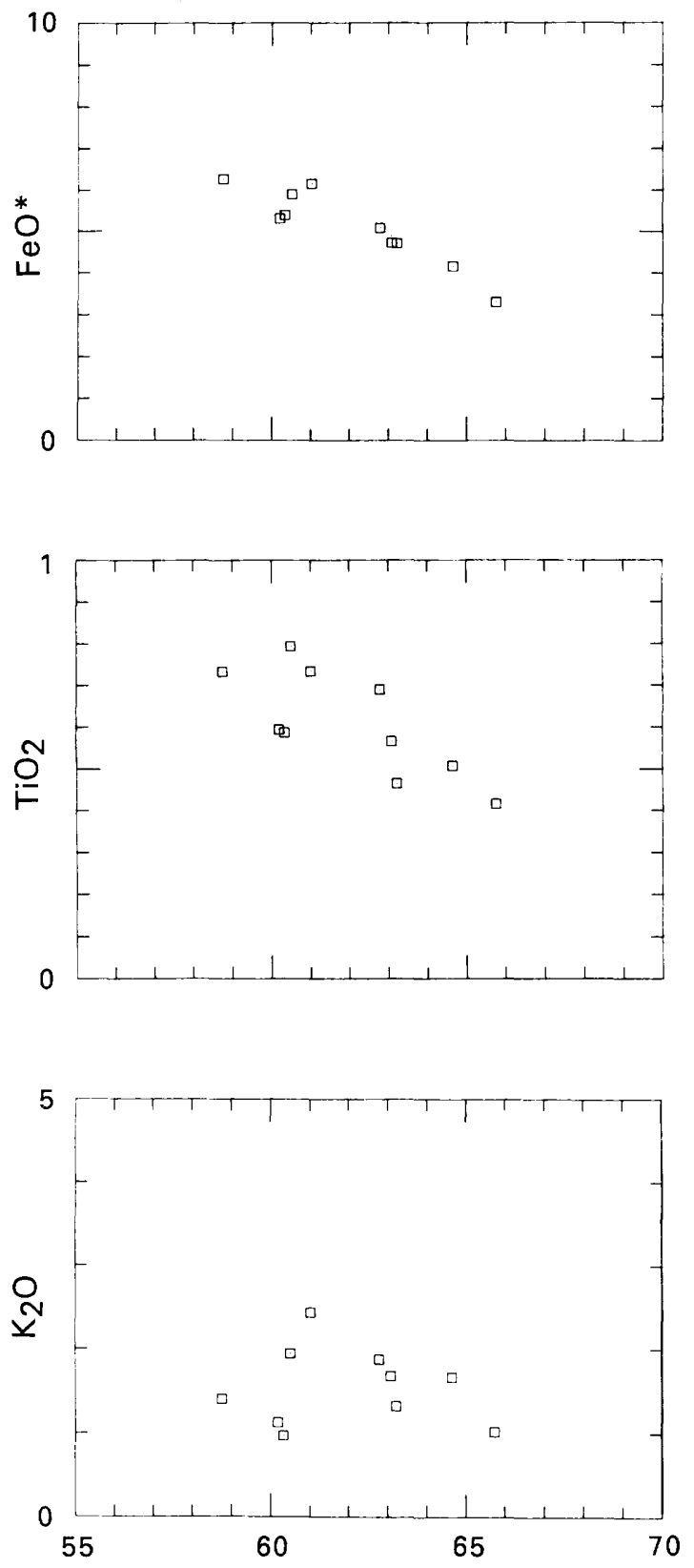

$\mathrm{SiO}_{2}$ CONTENT, IN WEIGHT PERCENT

Figure 6. Major-element oxides versus $\mathrm{SiO}_{2}$ variation diagrams for rocks from Speel River pluton. 
Table 2. Potassium-argon ages and analytical data for the Speel River pluton, south of Juneau, Alaska

[Potassium-argon analysis and age determinations performed at U.S. Geological Survey laboratories, Menlo Park, Calif.]

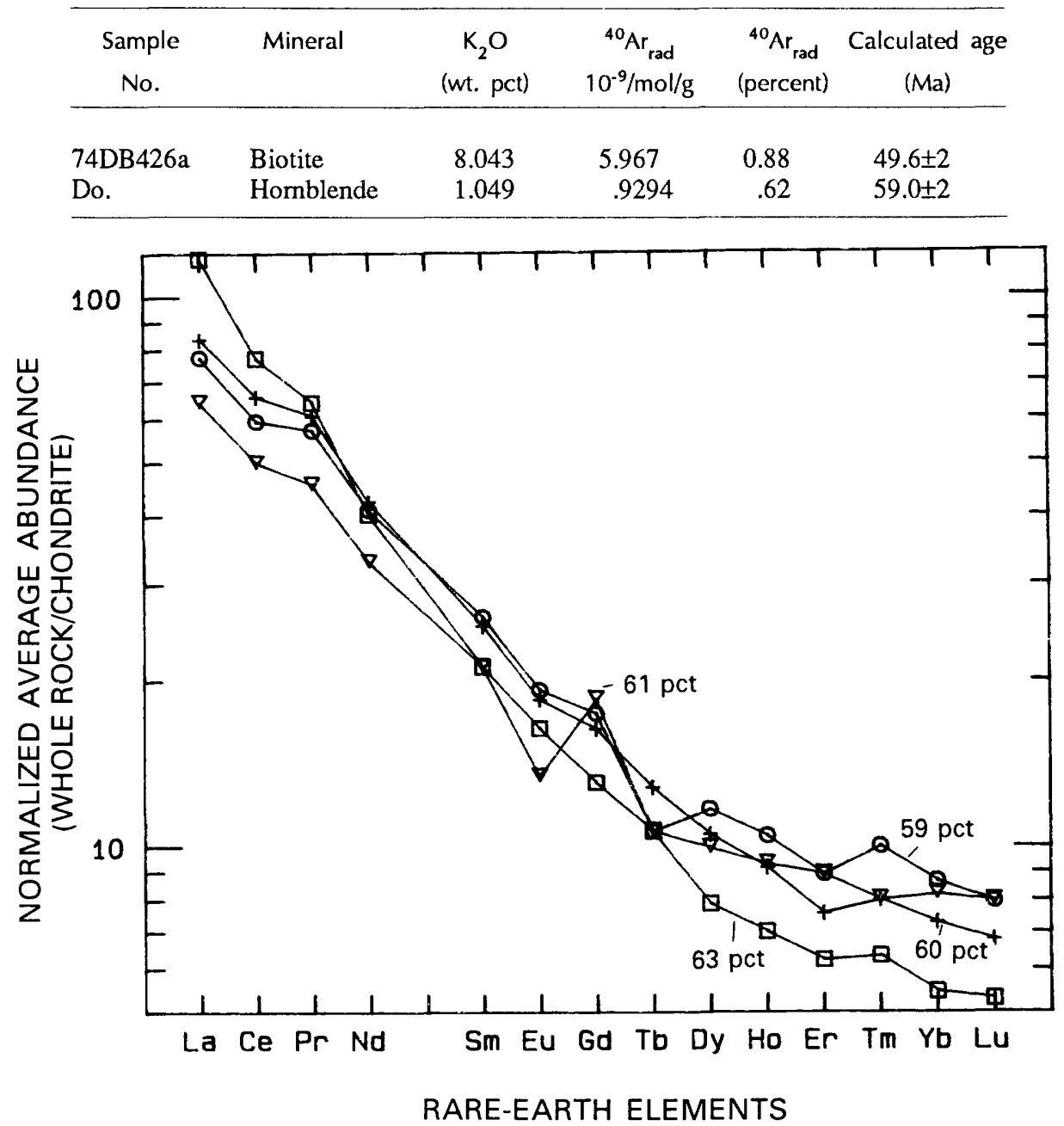

Figure 7. Chondrite-normalized rare-earth-element (REE) plot of representative samples from Speel River pluton. Line symbols: box (85DB105a) is magnetite-bearing biotitehornblende tonalite with C.I. of 20 ; plus sign (85EL109a) is magnetite bearing biotitehornblende tonalite with C.I. of 25; open circle (85EL061a) is magnetite-bearing sphene-biotite-hornblende tonalite with C.I. of 16; and inverted triangle (85DB108a) is hornblende-biotite granodiorite with C.I. of 13. Numbers indicate $\mathrm{SiO}_{2}$ content in weight percent.

(Wilcox, 1979). Evidence of postemplacement differentiation is lacking. The generally homogeneous, equigranular, and relatively coarse grained texture of the pluton indicates that it solidified slowly as a single cooling unit. The locally strong penetrative fabric formed late in the emplacement and solidification sequence during regional deformation and metamorphism (Brew and others, 1989) and is superposed on weakly developed local flow foliation.

Other segments of the great tonalite sill in southeastern Alaska are similar in appearance to the Speel River pluton in texture, lithology, and chemistry (Brew,
1988; Brew and Grybeck, 1984; Brew and Ford, 1984b). Some, however, are smaller in size, are more deformed and metamorphosed, and contain much more K-feldspar and more abundant granodiorite (Brew and Grybeck, 1984; Ford and Brew, 1981).

\section{REFERENCES CITED}

Barker, Fred, 1979, Trondhjemite: Definition, environment and hypotheses of origin, in Barker, Fred, ed., Trondhjemites, dacites, and related rocks: New York, Elsevier, p. 1-12. 
Brew, D.A., 1988, Latest Mesozoic and Cenozoic magmatism in southeastern Alaska-A synopsis: U.S. Geological Survey Open-File Report 88-405, 41 p.

Brew, D.A., and Ford, A.B., 1978, Megalineament in southeastern Alaska marks southwest edge of Coast Range batholithic complex: Canadian Journal of Earth Science, v. 15 , no. 11 , p. $1763-1772$.

1981, The Coast plutonic complex sill, southeastern Alaska, in Albert, N.R.D., and Hudson, Travis, eds., The United States Geological Survey in Alaska: Accomplishments during 1979: U.S. Geological Survey Circular 823-B, p. B96-B99.

1983, Comment on Monger, J.W.H., Price, R.A., and Tempelman-Kluit, D.J., 1982, Tectonic accretion and the origin of two major metamorphic and plutonic welts in the Canadian Cordillera: Geology, v. 11, p. 427-429.

1984a, Tectonostratigraphic terranes in the Coast plutonic-metamorphic complex, southeastern Alaska, in Reed, K.M., and Bartsch-Winkler, S., eds., The United States Geological Survey in Alaska: Accomplishments during 1982: U.S. Geological Survey Circular 939, p. 90-93.

1984b, The northern Coast plutonic complex, southeastern Alaska and northwestern British Columbia, in Coonrad, W.L., and Elliott, R.L., eds., The United States Geological Survey in Alaska: Accomplishments during 1981: U.S. Geological Survey Circular 868, p. 120-124. -1986 , Preliminary reconnaissance geologic map of the Juneau, Taku River, Atlin and parts of the Skagway 1:250,000 quadrangles, southeastern Alaska: U.S. Geological Survey Open-File Report 85-395, 23 p., scale $1: 250,000,2$ sheets.

1987, Confirmation of the empirical correlation of $\mathrm{Al}$ in hornblendes with pressure of solidification of calcalkaline plutons: Comment on miscorrelation of plutons: American Mineralogist, v. 72, p. 1017.

Brew, D.A., Ford, A.B., and Himmelberg, G.L., 1989, Evolution of the western part of the Coast plutonicmetamorphic complex, south-eastern Alaska, USA: a summary, in Daly, J.S., and others, eds., Evolution of metamorphic belts, Geological Society Special Publication no. 42, p 447-452.

Brew, D.A., and Grybeck, D., 1984, Geology of the Tracy Arm-Fords Terror wilderness study area and vicinity, in U.S. Geological Survey and U.S. Bureau of Mines, Mineral resources of the Tracy Arm-Fords Terror Wilderness Study Area and vicinity, Alaska: U.S. Geological Survey Bulletin 1525, p. 19-52.

Brew, D.A., and Morrell, R.P., 1983, Intrusive rocks and plutonic belts of southeastern Alaska, U.S.A., in Roddick, J.A., ed., Circum-Pacific plutonic terranes: Boulder, Colo., Geological Society of America Memoir 159, p. 171-193.
Cox, K.G., Bell, J.D., and Pankhurst, 1979, The interpretation of the igneous rocks: London, George Allen and Unwin, $450 \mathrm{p}$.

Ford, A.B., and Brew, D.A., 1981, Orthogneiss of Mount Juneau-An early phase of Coast Mountains plutonism involved in Barrovian regional metamorphism near $\mathrm{Ju}$ neau, in Albert, N.R.D., and Hudson, T.L., eds., The United States Geological Survey in Alaska: Accomplishments during 1979: U.S. Geological Survey Circular 823-B, p. B99-B102.

Gehrels, G.E., Brew, D.A., and Saleeby, J.B., 1984, Progress report on $\mathrm{U} / \mathrm{Pb}$ (zircon) geochronologic studies in the Coast plutonic-metamorphic complex east of Juneau, southeastern Alaska, in Reed, K.M., and BartschWinkler, S., eds,. The United States Geological Survey in Alaska: Accomplishments during 1982: U.S. Geological Survey Circular 939, p. 100-102.

Hollister, L.S., Grissom, G.C., Peters, E.K., Stowell, H.H., and Sisson, V.B., 1987, Confirmation of the empirical correlation of $\mathrm{Al}$ in hornblende with pressure of solidification of calc-alkaline plutons: American Mineralogist, v. 72, p. 231-239.

Irvine, T.N., and Baragar, W.R., 1971, A guide to the chemical classification of the common volcanic rocks: Canadian Journal of Earth Sciences, v. 8, no. 5, p. 523-548.

Miller, J.C., 1962, Geology of waterpower sites on Crater Lake, Long Lake, and Speel River near Juneau, Alaska: U.S. Geological Survey Bulletin 1031-D, p. D71-D101.

Monger, J.W.H., Price, R.A., and Tempelman-Kluit, D.J., 1982, Tectonic accretion and the origin of two major metamorphic plutonic welts in the Canadian Cordillera: Geology, v. 10 , p. $70-75$

Norman, M.B., 1974, Improved techniques for selective staining of feldspar and other minerals using amaranth: U.S. Geological Survey Journal of Research, v. 2, no. 1, p. 73-79.

Shand, S.J., 1947, Eruptive rocks: New York, Wiley.

Streckeisen, A.L., 1973, Plutonic rocks-Classification and nomenclature recommended by the I.U.G.S. subcommission on the systematics of igneous rocks: Geotimes, v. 18, no. 10, p. $26-30$.

Wilcox, R.E., 1979, The liquid line of descent and variation diagrams, in Yoder, H.S., Jr., ed., 1979, The evolution of the igneous rocks: Princeton, N.J., Princeton University Press, p. 205-232.

\section{Reviewers:}

Robert A. Loney Donald C. Ross 


\title{
Epigenetic Hydrothermal Origin of the Groundhog Basin-Glacier Basin Silver-Tin-Lead-Zinc Deposits, Southeastern Alaska
}

\author{
By Rainer J. Newberry and David A. Brew
}

\begin{abstract}
The Groundhog Basin-Glacier Basin area contains stratiform and vein deposits of silver-, tin-, lead-, and zinc-bearing sulfides near a stock of altered Miocene granite porphyry. The deposits are exposed for more than $4 \mathrm{~km}$ along strike and contain disseminated, laminated, and massive sulfide minerals. The ores are largely massive pyrrhotite, sphalerite, and galena, with lesser pyrite, arsenopyrite, chalcopyrite, and cassiterite. The ores were originally interpreted as epigenetic replacement deposits, but more recently have been interpreted as volcanogenic massive sulfide or as metamorphosed ores of uncertain origin. Textural, compositional, and zonation characteristics of the ores, together with "tin granite" type alteration and mineralization of the Miocene granite, indicate that the original replacement interpretation was correct.

Previous workers estimated that the Groundhog Basin massive sulfide deposits contain "several hundred thousand" tonnes of identified resources with 8 percent zinc, 1.5 percent lead, and $1.5 \mathrm{oz} / \mathrm{t}$ silver and that the disseminated sulfide deposits there contain "several hundred thousand" tonnes of identified resources with 2.5 percent zinc and 1 percent lead. The Glacier Basin disseminated sulfide deposits were estimated to contain "many hundred thousand" tonnes of identified resources with 1.6 percent zinc and 0.1 percent lead, and the quartz-fluorite veins there were estimated to contain "several million" tonnes of identified resources with 0.14 percent zinc and 0.09 percent lead. We estimate that at Groundhog Basin at least 1 million tonnes of undiscovered resources containing 0.8 percent tin are also present. The lead and zinc resources are subeconomic and additional exploration is required to determine if the tin resource is economic or subeconomic.
\end{abstract}

\section{INTRODUCTION}

The Groundhog Basin-Glacier Basin area contains disseminated, laminated, and massive sulfide mineralization in both well-defined ore beds and veins near an altered Miocene tin granite porphyry stock. Previous workers have interpreted the ores as (1) epigenetic replacements related to the granites (Gault and others,
1953), (2) volcanogenic deposits, with some graniteremobilized veins (Grybeck and others, 1984; Berg, 1984), or (3) metamorphosed ores of uncertain origin (Nokleberg and others, 1987). The area has also been drilled as a porphyry molybdenum prospect, but no significant molybdenum deposit has been found. Our purpose was to reexamine the evidence for the origin of this mineralization in order to better evaluate the mineral resources. We agree with the epigenetic interpretation of Gault and others (1953) and suggest that likely analogs to the Groundhog Basin deposits are the carbonate-hosted, massive pyrrhotite-cassiterite replacement bodies at Renison Bell, Mount Bischoff, and Mount Cleveland, Tasmania, and Kochiu, southern China (Laznicka, 1985). This is a preliminary report and therefore does not include a complete array of supporting chemical data and sample descriptions.

We wish to acknowledge the previous work by AMAX geologists Robert P. Morrell, Ken Fink (deceased), Joe Meigs, and Ted Schassberger; their unpublished work provided important background for this study. Morrell's providing us specimens for examination led directly to our study. We also thank Ken Eichner for providing access to unpublished company reports.

\section{GEOLOGY OF THE DEPOSITS}

The Groundhog Basin-Glacier Basin area deposits occur in a well-layered sequence of garnetbiotite-quartz-feldspar schist and gneiss that includes minor amounts of marble in 0.5 - to 1.0 -m-thick layers (fig. 1; Gault and others, 1953). This unit is the biotite schist unit of Brew and others (1984). Immediately to the west of the schist (fig. 1) is a slightly metamorphosed and deformed 90- to 95-Ma tonalite, quartz diorite, and granodiorite pluton (fig. 1; Brew and others, 1984; Hunt, 1986; Hunt and Brew, 1986) that is similar to plutons described from elsewhere in the Petersburg region by Burrell (1984a,b,c). The 62-Ma foliated tonalite sill, 


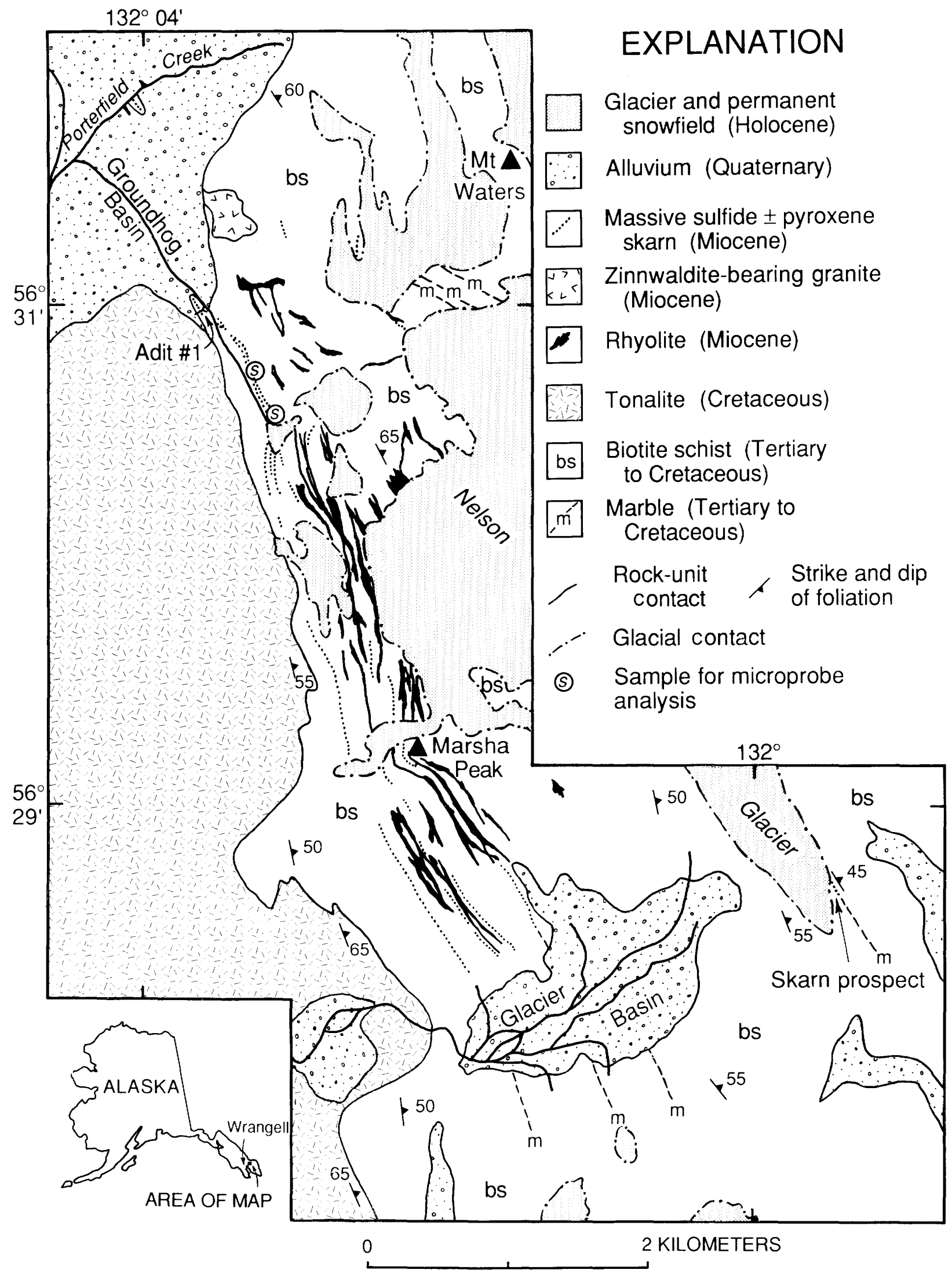

Figure 1. Location map and general geology of the Groundhog Basin-Glacier Basin area. Modified from Gault and others (1953) and Brew and others (1984). 
referred to informally as the great tonalite sill (Brew, 1988), lies east of the metamorphic unit and beyond the area shown in figure 1 . The metamorphism is considered to be Late Cretaceous and early Tertiary in age, and the grade in general increases toward the sill. The rocks in the Groundhog Basin-Glacier Basin area were later hornfelsed by the 15- to 17-Ma zinnwaldite-bearing granite porphyry stock, and the original metamorphic features are therefore not clear. The biotite schist unit is obviously hornfelsed in a 50- to 100-m-wide zone around the zinnwaldite-bearing granite plug in both surface exposures and drill core. Dikes, sills, and plugs of rhyolite porphyry and granite are present in outcrop throughout the area and have been intersected by diamond-drill holes. Basaltic dikes and sills are also common.

Gault and others (1953) made detailed maps of the prospects and described the sulfide bodies as replacements of "pyroxene granulite" beds. High-grade massive sulfide ore beds, up to $1 \mathrm{~m}$ thick and discontinuously traceable for more than $4 \mathrm{~km}$ along strike, occur in the biotite schist unit (fig. 1). Individual beds can only be traced in outcrop for about $300 \mathrm{~m}$, and unpublished industry diamond-drilling information indicates that maximum downdip continuity of individual beds rarely exceeds $100 \mathrm{~m}$. The ore consists of massive, locally laminated pyrrhotite, sphalerite, and galena with lesser pyrite, arsenopyrite, chalcopyrite, and cassiterite. Most of the silver is probably contained in the galena (Gault and others, 1953, p. 22). Veins of quartz, sphalerite, and galena, both with and without fluorite, are sporadically distributed throughout both Groundhog Basin and Glacier Basin, but are most common within 100 to $300 \mathrm{~m}$ of either granite or rhyolite outcrops. Quartz, carbonate, clinopyroxene, amphibole, chlorite, and white mica, with minor fluorite and traces of tourmaline, are the common gangue minerals in both massive ore and veins. Clinopyroxene occurs as medium- to coarse-grained, randomly oriented masses with minor garnet, idocrase, and plagioclase. In the vicinity of massive ore, the clinopyroxene is retrograded to a mixture of very fine grained amphibole, chlorite, quartz, calcite, and sulfide.

Petrographic study and unpublished industry data indicate that cassiterite is also a near-ubiquitous component of the massive sulfide ore in the Groundhog Basin area. All cassiterite observed in thin section, however, occurs as individual grains and grain clusters 0.1 to $1 \mathrm{~mm}$ in size and is not identifiable in hand sample (fig. 2). It is typically intergrown with quartz, sphalerite, pyrrhotite, and rare fluorite. Near the zinnwaldite-bearing granite (fig. 1), massive sulfide samples commonly contain several percent cassiterite; grab samples assay up to 18 percent $\mathrm{SnO}_{2}$ (unpublished industry data). Tin contents of 100 to $500 \mathrm{ppm}$ are common in sphalerite-galenafluorite veins present up to $1 \mathrm{~km}$ from the zinnwalditebearing granite plug and in biotite-veined hornfels samples.
The chemical composition of the zinnwalditebearing granite stock indicates that it has the characteristics of a tin granite. Major- and minor-oxide concentrations of representative unaltered samples are, except for tungsten, virtually identical to those of average tin granites (table 1). Tin granites differ from average granites in the relatively high abundances of fluorine, tin, tungsten, niobium, and rubidium, and relatively low abundances of titanium, iron, calcium, barium, strontium, and magnesium. The analyses for the Groundhog Basin granite and average tin granites also differ from typical molybdenum-porphyry-related granites in that the latter have high $\mathrm{Fe}_{2} \mathrm{O}_{3} / \mathrm{FeO}$ ratios (table 1). Unpublished industry and limited USGS geochemical analyses of surface and core samples show that high rubidium, niobium, fluorine, and tin are very common in the granite plug and underscore the very high potential for incompatible-element-related ore deposits in the Groundhog Basin area.

Petrographic and hand-specimen examination of the Miocene granitic rocks shows many alteration/mineralization features characteristic of tin-mineralized systems. Alteration of the granite to albite-zinnwaldite (brown lithium-bearing muscovite)-fluorite-topaz-tour-

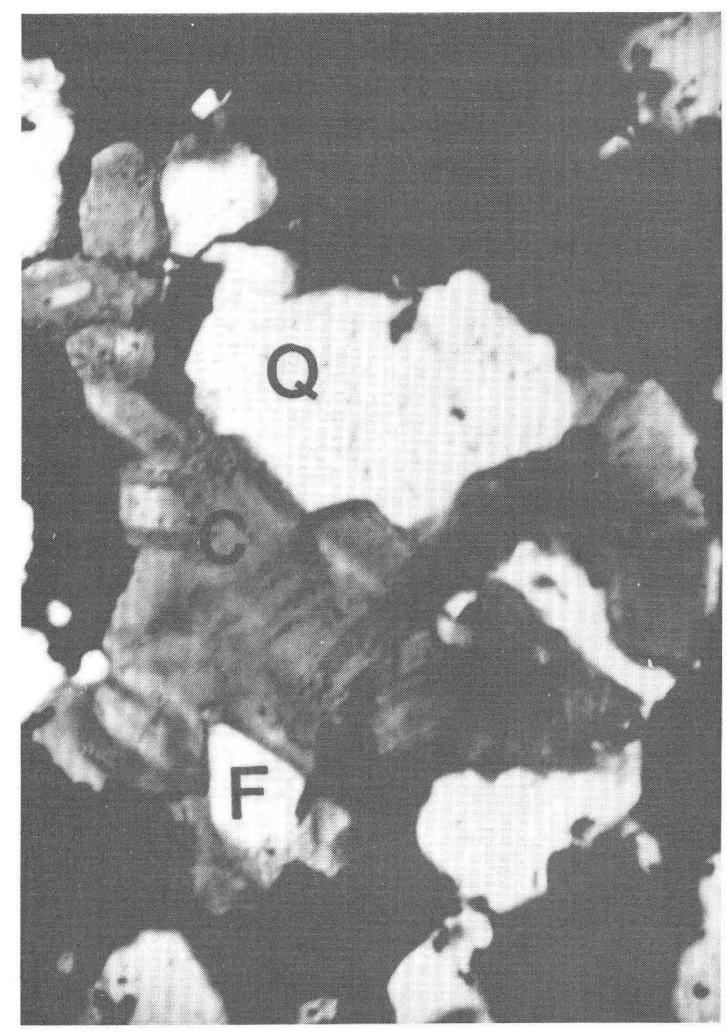

Figure 2. Transmitted light photomicrograph of typical Groundhog Basin massive sulfide ore. C, twinned polycrystalline cassiterite aggregate; $Q$, quartz; F, fluorite; black, pyrrhotite and sphalerite. Field of view is $1 \mathrm{~mm}$ wide. 
Table 1. Comparison of representative unaltered granite composition from the Groundhog Basin area with other typical granite compositions

[Analyses: 1, trace elements are average values from USGS and unpub. industry data; 2, Tischendorf (1977); Clark and Muecke (1985); 3, Hudson and others (1979); 4, White and others (1981); Carten and others (1988); 5, LeMaitre (1976); Krauskopf (1979)]

\begin{tabular}{|c|c|c|c|c|c|}
\hline & $\begin{array}{l}\text { Groundhog } \\
\text { Basin granite }\end{array}$ & $\begin{array}{c}\text { Average tin } \\
\text { granite }\end{array}$ & $\begin{array}{l}\text { Quartz Hill } \\
\text { Mo deposit } \\
\text { granite }\end{array}$ & $\begin{array}{c}\text { Henderson Co, } \\
\text { Mo deposit } \\
\text { granite }\end{array}$ & $\begin{array}{c}\text { Average } \\
\text { granite }\end{array}$ \\
\hline & (1) & (2) & (3) & (4) & (5) \\
\hline \multicolumn{6}{|c|}{ Analysis, weight percent } \\
\hline $\mathrm{SiO}_{2}$ & 74.4 & 74.2 & 75.0 & 74.9 & 71.3 \\
\hline $\mathrm{Al}_{2} \stackrel{2}{2}_{3}$ & 13.5 & 14.1 & 13.3 & 13.3 & 14.3 \\
\hline $\mathrm{Fe}_{2} \mathrm{O}_{3}$ & .07 & .21 & .63 & .30 & 1.21 \\
\hline $\mathrm{FeO}^{2}$ & .76 & .81 & .41 & .19 & 1.64 \\
\hline $\mathrm{MgO}$ & .10 & .10 & .2 & .05 & .71 \\
\hline $\mathrm{CaO}$ & .42 & .51 & .8 & .57 & 1.84 \\
\hline $\mathrm{Na}, \mathrm{O}$ & 4.28 & 4.11 & 3.9 & 4.45 & 3.68 \\
\hline $\mathrm{K}_{2} \mathrm{O}$ & 4.51 & 4.32 & 4.04 & 5.30 & 4.07 \\
\hline $\mathrm{TiO}_{2}$ & .02 & .07 & .14 & .11 & .31 \\
\hline $\mathrm{P}_{2} \mathrm{O}_{5}$ & .05 & .26 & .05 & .01 & .12 \\
\hline $\mathrm{MnO}$ & .03 & .03 & .03 & .05 & .05 \\
\hline $\mathrm{F}$ & .38 & .4 & - & .2 & .08 \\
\hline $\mathrm{H}_{2} \mathrm{O}$ & .35 & .84 & .34 & .3 & .64 \\
\hline
\end{tabular}

Analysis, parts per million

\begin{tabular}{lrrrrr}
\hline Mo & 4 & 2 & 2 & - & 1.5 \\
W & 10 & 2 & - & - & 1.5 \\
$\mathrm{Sn}$ & 57 & 44 & - & 11 & 3 \\
$\mathrm{Zr}$ & 88 & 75 & 26 & 76 & 180 \\
$\mathrm{Ba}$ & 80 & 57 & 140 & 10 & 700 \\
$\mathrm{Sr}$ & 14 & 15 & 27 & 8 & 300 \\
$\mathrm{Rb}$ & 670 & 760 & - & 630 & 150 \\
$\mathrm{Nb}$ & 68 & 32 & 38 & 180 & 20 \\
\hline
\end{tabular}

maline greisen is common in the uppermost $200 \mathrm{~m}$ of the exposed body. Tin concentrations of 0.04 to 0.1 percent and fluorine concentrations of 0.5 to 2 percent are common in this upper zone. Zinnwaldite-albite-topazfluorite-cassiterite-pyrite-sphalerite veins, 0.2 to $2 \mathrm{~cm}$ thick, are also common in the upper part of the granite. Disseminated fluorite and topaz are also present at 0.5 to 1 percent concentrations in much of the unaltered granitic rock. Tourmaline is present as very fine grained crystals with zinnwaldite, and boron concentrations of several hundred parts per million are present. This alteration and mineralization in the granite suggest a strong link to the nearby tin-bearing massive sulfide bodies discussed above. The fluorite-bearing base-metal veins are similar to base-metal veins marginal to tinmineralized systems elsewhere (for example, Newberry, 1987), and hence are also likely related to the granite.

Application of the tin discriminant function of Burns and others (1988) to the major and minor (rubidium, zirconium, barium) element composition of the Miocene zinnwaldite-bearing granite at Groundhog
Basin indicates a greater than 95 percent likelihood of tin deposits related to the granite. This intrinsic high favorability for tin strongly suggests that the tin in both the granite and the massive sulfide is derived from the granite. It could be argued that the high tin values are granite-derived and superimposed on a preexisting massive sulfide deposit, but the absence of veining in the massive sulfide and the presence of very fine grained, disseminated cassiterite in the massive sulfide, intergrown with sulfide, quartz, carbonate, and minor fluorite, imply that the sulfide minerals and cassiterite were deposited together from granite-related hydrothermal fluids.

\section{REPLACEMENT ORIGIN OF THE DEPOSITS}

The massive and disseminated sulfides and the cassiterite occur in skarn environments. Both sulfide and calc-silicate replacement of the thin marble layers is present at a variety of scales (Gault and others, 1953) and the pyroxene granulites of Gault and others (1953) are actually skarns containing medium-grained, randomly oriented pyroxene and minor garnet. Fine-grained endoskarn (biotite schist, replaced in part by clinopyroxene) locally occurs adjacent to medium-grained clinopyroxene skarn. Pyroxene-rich zones in both skarn types are preferentially replaced by sulfide minerals, usually accompanied by minor carbonate and the hydrous silicates amphibole and chlorite. Mapping of an adit into one of the ore beds at Groundhog Basin (fig. 3) shows finegrained clinopyroxene-altered biotite schist (endoskarn) adjacent to medium-grained clinopyroxene skarn, with a complex body of massive sulfide restricted to the skarn zone. Gault and others (1953, pl. 10) show a 10-m-wide block of marble surrounded by sulfide-bearing pyroxene granulite $0.5 \mathrm{~km}$ north of Glacier Basin. Unpublished industry maps of the Nelson Glacier area (labeled "skarn prospect" on fig. 1) show a 2-m-wide marble bed with veins of galena-sphalerite-clinopyroxene. In drill core from Groundhog Basin, centimeter-wide veins of garnetpyroxene skarn with envelopes of wollastonite cut across layering in marble, and 1 - to 5 -cm-wide skarn zones are present between basalt dikes and marble.

Our mineralogical, chemical, and petrologic investigations indicate that the deposits are epigenetic hydrothermal replacements, skarns, and veins. As discussed below, four lines of evidence support this interpretation: (1) the ore textures are compatible with replacement and not with volcanogenic or metamorphosed sulfides; (2) the mineral compositions indicate a shallow, lowtemperature origin and neither a medium-grade metamorphic or volcanogenic origin; (3) the tin grade distribution is zoned and centered on the zinnwalditebearing granite plug; and (4) as discussed previously, the 
granitic rocks present display tin granite alteration/mineralization characteristics.

Ore textures are notoriously difficult to interpret due to the absence of rigorous, quantifiable criteria for establishing replacement or other origins, but metamorphosed ores have several clear characteristics (table 2). Thus, absence of those features indicates a nonmetamorphic origin. Missing in ores from the Groundhog Basin area are (1) evidence for metamorphic deformation; for example, fracturing of the brittle sulfides pyrite and arsenopyrite, and crack filling by the soft sulfides galena and chalcopyrite; (2) evidence for metamorphic growth of pyrite; for example, an abundance of large, rotated, porphyroblastic pyrites; and (3) evidence for annealing of grain boundaries; for example, develop-
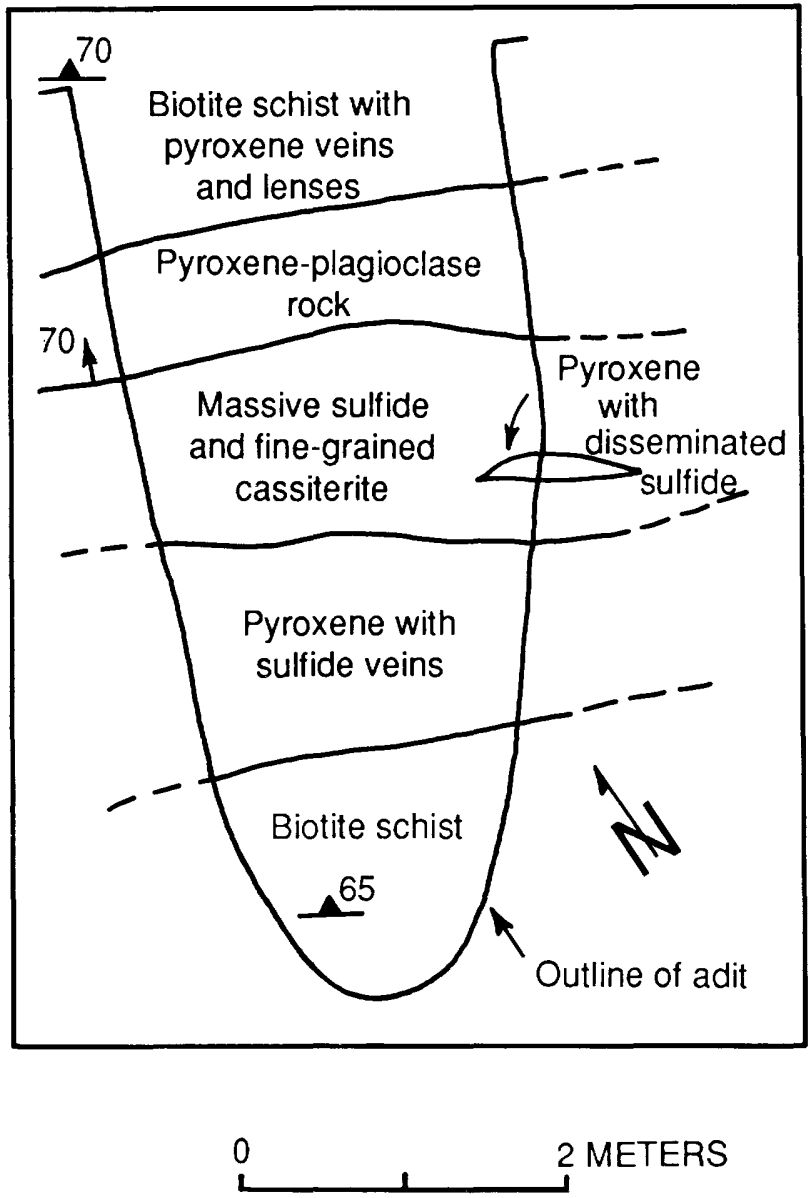

EXPLANATION

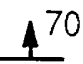

Contact showing dip--Dashed where approximately located

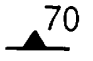

\section{Strike and dip of foliation}

Figure 3. Sketch map of adit \#1, Groundhog Basin. Location of adit shown on figure 1.
Table 2. Textural characteristics of Groundhog Basin ores compared to typical metamorphosed sulfides

[Criteria for metamorphosed ores from Volkes (1969) and Craig and Vaughn (1981)]

\begin{tabular}{ll}
\hline Metamorphosed sulfide ore & Groundhog Basin ore \\
\hline $\begin{array}{l}\text { Soft sulfides injected along } \\
\text { cleavages of silicates }\end{array}$ & $\begin{array}{l}\text { Sulfides intergrown with } \\
\text { felted masses of chlorite/ } \\
\text { replace clinopyroxene. }\end{array}$ \\
$\begin{array}{l}\text { muscovite/actinolite and } \\
\text { sulfide/calcite/quartz. }\end{array}$
\end{tabular}

Broken pyrite and arsenopyrite crystals; fractures filled by soft sulfides galena, chalcopyrite).

Kink-banding and polysynthetic twinning in pyrrhotite.

Curved cleavage traces in galena.

Curved rows of chalcopyrite inclusions in sphalerite.

120-degree triple junctions in monomineralic sulfide masses.

Large (up to $1 \mathrm{~cm}$ ), rounded pyrite porphyroblasts with abundant inclusions common.
Mostly equant pyrite and arsenopyrite in matrix of equant, softer sulfides.

No twinning observed in pyrthotite.

Straight cleavage traces.

Straight rows of chalcopyrite inclusions in sphalerite.

Grain boundary angles commonly vary from 80 to 160 degrees.

Pyrite grains are commonly small $(3 \mathrm{~mm})$ and free of inclusions. ment of 120-degree triple junctions in monomineralic sulfide aggregates.

The sulfide-silicate textures of the Groundhog Basin ore are compatible with a replacement origin and incompatible with a metamorphic origin. Quartz, carbonate, clinopyroxene, amphibole, chlorite, and white mica are the common gangue minerals with minor fluorite and traces of tourmaline. The phyllosilicates in the Glacier Basin-Groundhog Basin ores occur as fine to very fine grained, randomly oriented aggregates, some of which are pseudomorphic after idocrase. They do not display sulfide injections along cleavages, as is common in regionally metamorphosed sulfides. Clinopyroxenes occur as medium- to coarse-grained, randomly oriented masses with minor garnet, idocrase, and plagioclase. In the vicinity of massive ore, the clinopyroxenes are retrograded to a mixture of very fine grained amphibole, chlorite, quartz, calcite, and sulfide. The strong spatial association of retrograde clinopyroxene alteration and massive sulfide suggests instead that the bulk of sulfides were deposited during retrograde alteration; that is, associated with postmetamorphic hydrothermal alteration. 
Compositions of sulfide and silicate minerals from the Groundhog Basin area suggest low to moderate temperatures and pressures of formation and are not compatible with a history of moderate-grade regional metamorphism of volcanogenic ores. Microprobe compositions of sphalerites from sphalerite-pyrite-pyrrhotite assemblages yield 19.1 to 19.5 mole percent FeS, indicating pressure of about 1.3 $\pm 0.3 \mathrm{kbars}$ (Scott, 1973). Arsenopyrites with 31.6 to 32.1 atomic percent As, coexisting with pyrrhotite containing 47.6 to 48.2 atomic percent $\mathrm{Fe}$, indicate temperatures of 310 to $260{ }^{\circ} \mathrm{C}$ (Kretschmar and Scott, 1976). We interpret these pressure/temperature conditions to be original rather than to represent resetting of mineral compositions during Miocene plutonism, because (1) arsenopyrite is highly refractory; (2) the samples, which were taken more than $0.5 \mathrm{~km}$ from the granite plug and well beyond the hornfels zone, contain no veins or other signs of sulfide remobilization; and (3) silicate wallrocks surrounding the samples show no signs of low-temperature alteration.

Chlorite from Groundhog Basin massive ore has relatively low $\mathrm{Al}_{2} \mathrm{O}_{3}$ and $\mathrm{TiO}_{2}$ contents, which indicate formation of sub-biotite grades (Laird and Albee, 1981). The chlorite has atomic $\mathrm{Fe} /(\mathrm{Fe} \pm \mathrm{Mg})$ ratios greater than 0.6 , unlike ore-related chlorites from massive sulfide deposits (Urabe and others, 1983; Schmidt, 1988), which typically exhibit $\mathrm{Fe} /(\mathrm{Fe} \pm \mathrm{Mg})$ ratios less than 0.3 to 0.1 (fig. 4).

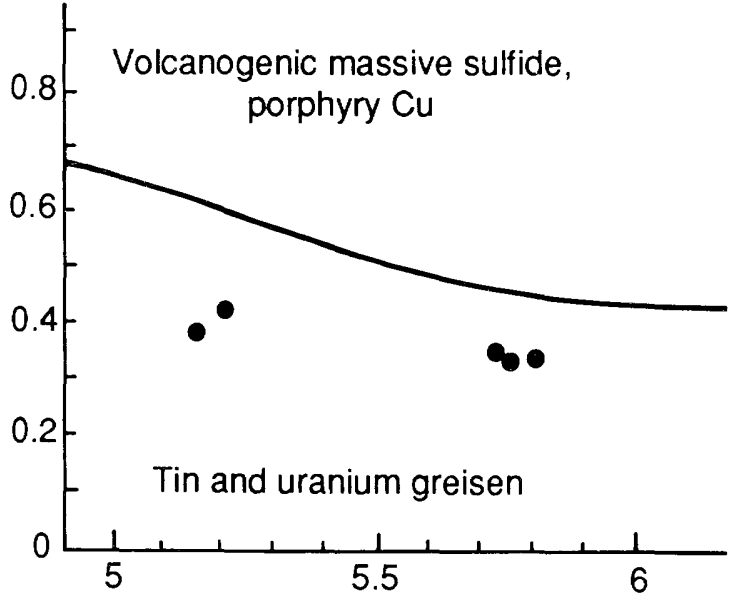

\section{NUMBER SILICONS PER 28 OXYGENS}

Figure 4. Microprobe compositions of chlorites from Groundhog Basin massive sulfide deposits (solid dots) plotted in relation to those from other greisen- and nongreisen-related deposits. Diagram modified from Strong and Chatterjee (1985) using data from Urabe and others (1983), Newberry (1987), Schmidt (1988), and Newberry (unpub. data, 1989).
White micas from Groundhog Basin massive ore have celadonite components compatible with either medium-grade metamorphism (Laird and Albee, 1981) or origin as a tin greisen (Strong and Chatterjee, 1985). These white micas, however, possess very low ( 0.4 percent and less) barium contents, unlike the Ba-rich ( 2 to 12 percent $\mathrm{BaO}$ ) alteration micas characteristic of volcanogenic massive sulfide deposits (for example, Arctic Camp in northern Alaska, Schmidt, 1988; Greens Creek in southeastern Alaska, R.J. Newberry, unpub. data).

The distribution of tin values in all rocks of the Groundhog Basin area shows little systematic pattern (unpub. industry report). Contouring of tin contents (fig. 5) of the massive sulfide ore, however, shows a strong spatial relationship to the exposed granite plug. Tin concentrations greater than 1 percent are common within $0.5 \mathrm{~km}$ of the plug, but concentrations greater than 0.1 percent are not known beyond about $1 \mathrm{~km}$ from the plug. Limited industry sampling also indicates that high copper and arsenic values accompany high tin grades, whereas

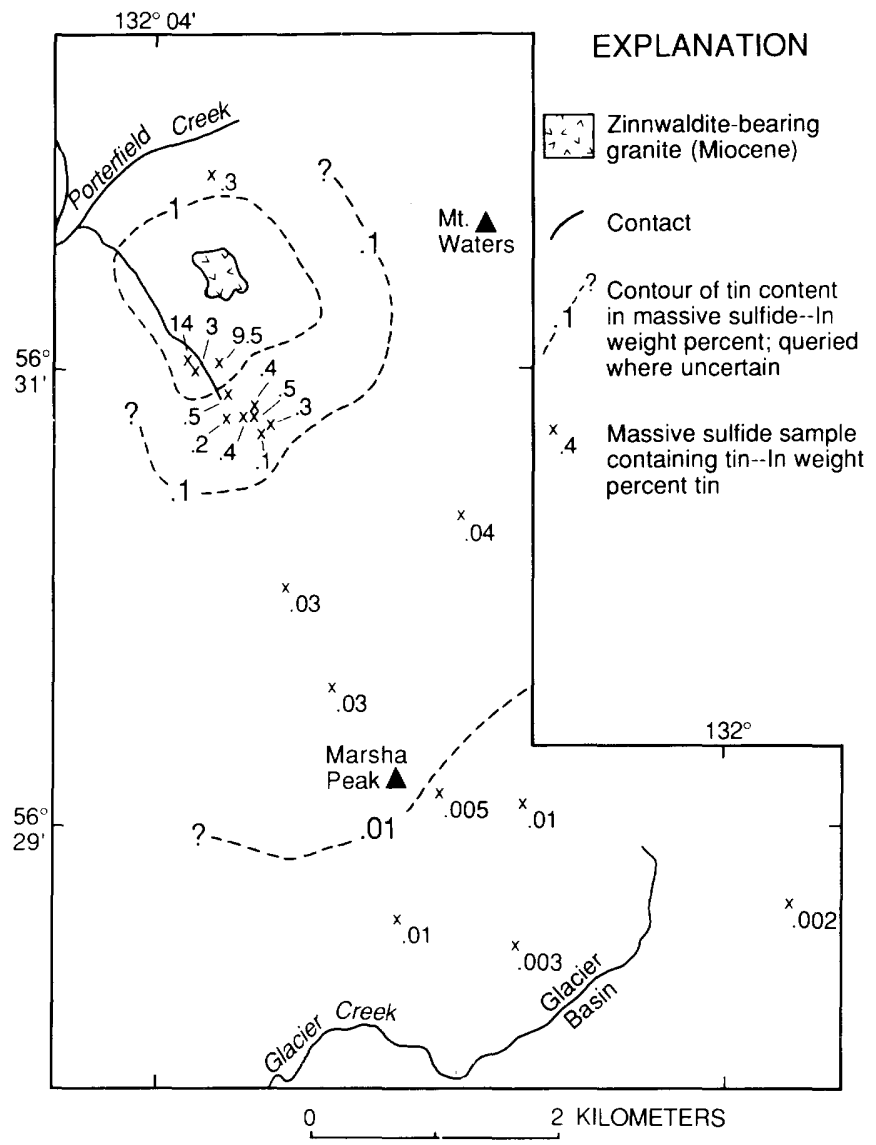

Figure 5. Map showing zoning of tin content in Groundhog Basin-Glacier Basin massive sulfide ore in relation to Miocene zinnwaldite-bearing granite at lower Groundhog Basin. Data courtesy of K. Eichner, President, TEMSCO Helicopters, Inc., and TEMSCO Airlines, Inc., Ketchikan, AK. 
higher lead grades are present peripheral to the high-tin zone. Silver is variably enriched (values of 5 to $1,000 \mathrm{ppm}$ reported) in both tin-rich and tin-poor massive sulfide.

Although such elevated tin contents are occasionally present in massive sulfide ores (as examples, 0.031 percent tin at Sullivan, British Columbia, Hamilton and others, 1983; 2.6 percent tin in a Kuroko-type deposit in Portugal, B.L. Reed, U.S. Geological Survey, oral commun., 1989), average grades in excess of 0.1 percent tin and grab-sample grades greater than 3 percent tin have not been reported from any massive sulfide deposit that is clearly volcanogenic (Patterson and others, 1981). Other granite-related elements present in high abundances in the Groundhog Basin massive ores include beryllium (up to $100 \mathrm{ppm}$ ), boron (up to 5,000 ppm), and fluorite (up to 0.3 percent). Both the high abundance of tin (and the other elements) and the localization of high tin values around the granite stock indicate a causal relation between the granite and the mineralization.

Based on the preceding information, we suggest that initial mineralization in the Groundhog Basin area resulted in formation of pervasive albite-zinnwaldite greisen in the cupola of an evolved granite, limited pyroxene-garnet skarn in carbonates, and pyroxeneplagioclase endoskarn in biotite schist and mafic dikes. This early mineralization was followed by lower temperature zinnwaldite-sphalerite-cassiterite veining in the granite and metamorphic rocks and by massive sulfidecassiterite replacement of marble and pyroxene-rich skarn and endoskarn. Peripheral sphalerite-galenafluorite veins probably represent late, distal, and lowest temperature expressions of the granite-related hydrothermal system.

\section{RESOURCES}

Gault and others (1953) estimated that the Groundhog Basin massive sulfide deposits contained "several hundred thousand" tonnes of resources containing 8 percent zinc, 1.5 percent lead, and $1.5 \mathrm{oz} / \mathrm{t}$ silver. The disseminated sulfide deposits there contained "several hundred thousand" tonnes with 2.5 percent zinc and 1 percent lead. The Glacier Basin disseminated sulfide deposits were estimated to contain "many hundred thousand" tonnes of resources containing 1.6 percent zinc and 0.1 percent lead and the quartz-fluorite veins there to contain "several million" tonnes with 0.14 percent zinc and 0.09 percent lead.

We do not have quantitative data sufficient to make a comparable estimate of the tin content of the Groundhog Basin deposits. However, we are convinced that significant undiscovered tin and perhaps silver resources are present at Groundhog Basin, and therefore propose a preliminary estimate. As background, the Gault and others' (1953) estimates of zinc, lead, and silver content can be compared with the worldwide grade and tonnage models of Mosier and others (1986) for polymetallic replacement deposits. That comparison shows that the Groundhog Basin deposits are somewhere between the 90th and 60th percentiles in tonnage, near the 20th percentile for zinc grade, and near the 80th percentile for both lead and silver. Thus, considered as a polymetallic replacement deposit, Groundhog Basin is relatively small and can be generalized as of moderate grade.

Considering now the tin resources at Groundhog Basin, we estimate them as undiscovered resources in one deposit that is relatively low in tonnage and moderate in grade. The worldwide grade and tonnage model for replacement tin deposits (Menzie and Reed, 1986), which is based on only six deposits, all in Australia, indicates that such a deposit would contain about 1 million tonnes of ore containing 0.8 percent tin. We estimate that the Groundhog Basin deposit has undiscovered tin resources of at least that tonnage and grade, but emphasize the great uncertainties in the estimate.

\section{DISCUSSION}

Gault and others (1953) interpreted the sulfidebearing bodies at Groundhog Basin and Glacier Basin as replacement and related vein deposits. Grybeck and others (1984) reinvestigated the area and concluded (perhaps based on the lateral continuity of the massive sulfide ore beds) that the deposits were "metamorphosed and locally remobilized stratiform, syngenetic massive sulfide deposits" in a metamorphic terrane of "highgrade schist and gneiss." These workers considered the nearby zinnwaldite-bearing granite to be unrelated to the massive sulfides, except that the dike-related veins were interpreted to have possibly been remobilized from the massive sulfide layers. Nokleberg and others (1987) followed Grybeck and others (1984) and classified the Groundhog Basin area deposits as "metamorphosed sulfides" of uncertain (volcanogenic or sedimentary) parentage.

We interpret the evidence presented by Gault and others (1953) and in this report to indicate that the deposits are replacement in origin and are similar to the carbonate-hosted, massive pyrrhotite-cassiterite replacement bodies at Renison Bell (Patterson and others, 1981; Reed, 1986), Mount Bischoff, and Mount Cleveland, Tasmania, and Kochiu, southern China (Laznicka, 1985). These deposits have massive to laminated textures, small amounts of skarn mineralization, and tin grades of 0.3 to 3.65 percent, and tin is present as very fine grained (invisible in hand specimen) cassiterite. These deposits are also associated with greisen-altered, tin-tungstenfluorine-rubidium-enriched granites. Conditions of formation of the Renison Bell (Patterson and others, 1981) and Mount Cleveland (Collins, 1981) deposits are similar 
to those determined for the Groundhog Basin deposits, namely pressures of approximately 1 to $1.5 \mathrm{kbar}$ and temperatures of 300 to $350{ }^{\circ} \mathrm{C}$. Both Mount Bischoff and Mount Cleveland also exhibit a zonation of metal grades with high copper and tin close to the granite and high lead and zinc farther from the granite, similar to the Groundhog Basin pattern.

Southeastern Alaska has significant known porphyry molybdenum deposits associated with late Tertiary granites (for example, Quartz Hill, the Muir Inlet nunatak deposit in Glacier Bay, Mount Ogden). This report shows that significant tin mineralization occurs with at least one of the late Tertiary granites and suggests that the granites are favorable for a variety of incompatible element deposits. Differences between molybdenum and tin metallogeny in strongly fractionated granite systems may be largely due to differences in intrinsic oxidation states of the related magmas. Keith and Shanks (1988) indicated that high magmatic oxidation states are important for the development of a porphyry molybdenum deposit, whereas Patterson and others (1981) and Swanson and others (1988) indicated that low magmatic oxidation states are required for formation of greisentype tin deposits. These generalizations are compatible with the strong differences in $\mathrm{Fe}_{2} \mathrm{O}_{3} / \mathrm{FeO}$ ratios of Tertiary granites from Quartz Hill and Groundhog Basin (table 1). If such differences in the magmatic environment are a function of oxygen fugacity, then tin deposits may well be expected to occur with other, similar fractionated granites in southeastern Alaska. Further, the elements uranium, tungsten, niobium, and tantalum are also associated with strongly fractionated granites (fractionating under still different conditions?) and might also be associated with southeastern Alaska Tertiary granites.

Although the stratabound Groundhog Basin massive sulfide deposits are here shown to be granite-related, and not volcanogenic in origin, it should not be inferred that other stratabound massive sulfide deposits in southeastern Alaska are necessarily of epigenetic origin (Stowell, 1985). Rather, we suggest that integrated geologic, mineralogic, and mineral compositional studies be employed to establish the origins of critical mineral deposits in this area of complex geology and metallogeny.

\section{REFERENCES CITED}

Berg, H.C., 1984, Regional geologic summary, metallogenesis, and mineral resources of southeastern Alaska: U.S. Geological Survey Open-File Report 84-572, 298 p., scale $1: 600,000$.

Brew, D.A. 1988, Latest Mesozoic and Cenozoic igneous rocks of southeastern Alaska-A synopsis: U.S. Geological Survey Open-File Report 88-405, 29 p.

Brew, D.A., Ovenshine, A.T., Karl, S.M., and Hunt, S.J., 1984, Preliminary reconnaissance geologic map of the Petersburg and parts of the Port Alexander and Sumdum
1:250,000 quadrangles, southeastern Alaska: U.S. Geological Survey Open-File Report 84-405, 42 p., 2 sheets, scale $1: 250,000$.

Burns, L.E., Johnson, K.J., and Newberry, R.J., 1988, Discriminant function for separating tin- from non-tin-granites; Application to the Hope granite suite, eastern interior Alaska: Alaska Division of Geological and Geophysical Surveys Public Data File 88-12, 27 p.

Burrell, P.D., 1984a, Cretaceous or younger plutonic rocks, Mitkof and Kupreanof Islands, southeast Alaska, in Coonrad, W.L., and Elliott, R.L., eds., The United States Geological Survey in Alaska: Accomplishments during 1981: U.S. Geological Survey Circular 868, p. 124-126. 1984b, Late Cretaceous plutonic rocks, Petersburg quadrangle, southeast Alaska, in Bartsch-Winkler, Susan, and Reed, K.M., eds., The United States Geological Survey in Alaska: Accomplishments during 1982: U.S. Geological Survey Circular 939, p. 93-95.

1984c, Map and tables describing the AdmiraltyRevillagigedo intrusive belt plutons in the Petersburg 1:250,000 quadrangle, southeastern Alaska: U.S. Geological Survey Open-File Report 84-71, 1 sheet, scale $1: 250,000$.

Carten, R.B., Geraghty, E.P., Walker, B.M., and Shannon, J.R., 1988, Cyclic development of igneous features and their relationship to high-temperature hydrothermal features in the Henderson porphyry molybdenum deposit, Colorado: Economic Geology, v. 83, p. 266-296.

Clark, D.B., and Muecke, G.K., 1985, Review of the petrochemistry and origin of the South Mountain batholith and associated plutons, Nova Scotia, Canada, in High heat production (HHP) granites, hydrothermal circulation and ore genesis: London, Institution of Mining and Metallurgy, p. 41-54.

Collins, P.L.F., 1981, The geology and genesis of the Cleveland tin deposit, western Tasmania; Fluid inclusion and stable isotope studies: Economic Geology, v. 76, p. 365-392.

Craig, J.R., and Vaughn, D.J., 1981, Ore microscopy and ore petrography: New York, Wiley Interscience, $406 \mathrm{p}$.

Gault, H.R., Rossman, D.L., Flint, G.M., Jr., and Ray, R.G., 1953, Some lead-zinc deposits of the Wrangell district, Alaska: U.S. Geological Survey Bulletin 998-B, p. 15-58.

Grybeck, Donald, Berg, H.C., and Karl, S.M., 1984, Map and description of the mineral deposits in the Petersburg and eastern Port Alexander quadrangles, southeastern Alaska: U.S. Geological Survey Open-File Report 84-837, 86 p., 1 sheet, scale 1:250,000.

Hamilton, J.M., Delaney, G.D., Hauser, R.L., and Ransom, P.W., 1983, Geology of the Sullivan deposit, Kimberly, B.C., Canada, in Sangster, D.F., ed., Short course in sediment-hosted stratiform lead-zinc deposits: Mineralogical Association of Canada, short course handbook, v. 8, p. 31-84.

Hudson, Travis, Smith, J.G., and Elliott, R.L., 1979, Petrology, composition, and age of intrusive rocks associated with the Quartz Hill molybdenite deposit, southeastern Alaska: Canadian Journal of Earth Sciences, v. 16, p. 1805-1822.

Hunt, S.J., 1986, Structural analysis of plutonic and metamorphic rocks in an area east of Wrangell, Alaska: U.S. Geological Survey Open-File Report 85-50, 34 p. 
Hunt, S.J., and Brew, D.A., 1986, Geometric structural analysis of part of the western Coast plutonic-metamorphic complex east of Wrangell, in Bartsch-Winkler, Susan, and Reed, K.M., eds., The United States Geological Survey in Alaska: Accomplishments during 1984: U.S. Geological Survey Circular 978, p. 102-108.

Keith, J.D., and Shanks, W.C., III, 1988, Chemical evolution and volatile fugacities of the Pine Grove molybdenum and ash flow system, southwestern Utah, in Taylor, R.P., and Strong, D.F., eds., Recent advances in the geology of granite-related mineral deposits: Canadian Institute of Mining and Metallurgy Special Volume 39, p. 402-423.

Krauskopf, K.P., 1979, Introduction to geochemistry, 2d edition: New York, McGraw-Hill, $617 \mathrm{p}$.

Kretschmar, U.L., and Scott, S.D., 1976, Phase relations involving arsenopyrite in the system Fe-As-S and their application: Canadian Mineralogist, v. 14, p. 364-386.

Laird, Jo, and Albee, A.L., 1981, Pressure, temperature, and time indicators in mafic schist: Their application to reconstructing the polymetamorphic history of Vermont: American Journal of Science, v. 281, p. 127-175.

Laznicka, Peter, 1985, Empirical metallogeny: Amsterdam, Elsevier, v. 1, 1758 p.

LeMaitre, R.W., 1976, The chemical variability of some common igneous rocks: Journal of Petrology, v. 17, p. 589-637.

Menzie, W.D., and Reed, B.L., 1986, Grade and tonnage model of replacement Sn, in Cox, D.P., and Singer, D.A., eds., Mineral deposit models: U.S. Geological Survey Bulletin 1693 , p. 62-63.

Mosier, D.L., Morris, H.L., and Singer, D.A., 1986, Grade and tonnage model of polymetallic replacement, in Cox, D.P., and Singer, D.A., eds., Mineral deposit models: U.S. Geological Survey Bulletin 1693, p. 101-104.

Newberry, R.J., 1987, Lode mineralization in the Lime PeakMount Prindle area, in Smith, T.E., Pessel, G.H., and Wiltse, M.A., eds., Mineral assessment of the Lime Peak-Mount Prindle area, Alaska: Alaska Division of Geological and Geophysical Surveys Report, p . 6-1 to 6-79.

Nokleberg, W.J., Bundtzen, T.K., Berg, H.C., Brew, D.A., Grybeck, Donald, Robinson, M.S., Smith, T.E., Yeend, Warren, and others, 1987, Significant metalliferous lode deposits and placer districts of Alaska: U.S. Geological Survey Bulletin 1786, 105 p.

Patterson, D.J., Ohmoto, H., and Solomon, M., 1981, Geologic setting and genesis of cassiterite-sulfide mineralization at Renison Bell, western Tasmania: Economic Geology, v. 76 , p. $393-438$.
Reed, B.L., 1986, Descriptive model of replacement Sn, in Cox, D.P., and Singer, D.A., eds., Mineral deposit models: U.S. Geological Survey Bulletin 1693, p. 61.

Schmidt, J.M., 1988, Mineral and whole-rock compositions of seawater-dominated hydrothermal alteration at the Arctic volcanogenic massive sulfide prospect, Alaska: Economic Geology, v. 83, p. 822-842.

Scott, S.D., 1973, Experimental calibration of the sphalerite geobarometer: Economic Geology, v. 68, p. 466-474.

Stowell, H.S., 1985, Sphalerite geobarometry in the Coast Range megalineament zone near Holkam Bay, southeastern Alaska, in Bartsch-Winkler, Susan, and Reed, K.M., eds., The United States Geological Survey in Alaska: Accomplishments during 1983: U.S. Geological Survey Circular 945, p. 96-99.

Strong, D.F., and Chatterjee, A.K., 1985, A review of some chemical and mineralogical characteristics of granitoid rocks hosting Sn, W, U, Mo deposits in Newfoundland and Nova Scotia, in High heat production (HHP) granites, hydrothermal circulation and ore genesis: London, Institution of Mining and Metallurgy, p. 489-516.

Swanson, S.E., Bond, J.F., and Newberry, R.J., 1988, Petrogenesis of the Ear Mountain tin granite, Seward Peninsula, Alaska: Economic Geology, v. 83, p. 46-61.

Tischendorf, G., 1977, Geochemical and petrographic characteristics of silicic magmatic rocks associated with rareelement mineralization, in Stemprok, M., Burnol, B., and Tischendorf, B., eds., Symposium, metallization associated with acid magmatism: Prague, Czechoslovakia, Geological Survey, v. 2, p. 41-96.

Urabe, Tetsuro, Scott, S.D., and Hattori, Keiko, 1983, A comparison of footwall-rock alteration and geothermal systems beneath some Japanese and Canadian volcanogenic massive sulfide deposits, in Ohmoto H., and Skinner, G.J., eds., The Kuroko and related volcanogenic massive sulfide deposits: Economic Geology Monograph 5: New Haven, Connecticut, Economic Geology Publishing Company, p. 345-364.

Volkes, F.M., 1969, A review of the metamorphism of sulfide deposits: Earth Science Reviews, v. 5, p. 99-143.

White, W.H., Bookstrom, A.A., Kamilli, R.J., Ganster, M.W., Smith, R.P., Ranta, D.E., and Steininger, R.C., 1981, Characteristics and origin of climax-type molybdenum deposits: Economic Geology, 75th Anniversary Volume, p. 270-316.

\section{Reviewers:}

Dennis Cox

Bruce Reed 


\title{
U.S. Geological Survey Reports on Alaska Released in 1988
}

\author{
Compiled by Ellen R. White
}

[Some reports dated 1987 did not become available until 1988; they are included in this listing.]

\section{ABBREVIATIONS}

B1786 Nokleberg, W.J., Bundtzen, T.K., Berg, H.C., Brew, D.A., Grybeck, Donald, Robinson, M.S., Smith, T.E., and Yeend, Warren, 1987, Significant metalliferous lode deposits and placer districts of Alaska: U.S. Geological Survey Bulletin 1786, 104 p., 2 pls.

C1016 Galloway, J.P., and Hamilton, T.D., eds., 1988, Geologic studies in Alaska by the U.S. Geological Survey during 1987: U.S. Geological Survey Circular 1016.

C1025 Carter, L.M.H., ed., 1988, USGS research on energy resources-1988, program and abstracts: U.S. Geological Survey Circular 1025. [V.E. McKelvey Forum on Mineral and Energy Resources].

OF 87-63 Jacobson, M.L., and Rodriguez, T.R., compilers, 1986, National Earthquake Hazards Reduction Program, Summaries of technical reports, volume 23: U.S. Geological Survey Open-File Report $87-63$.

OF 88-16 Jacobson, M.L., and Rodriguez, T.R., compilers, 1988, National Earthquake Hazards Reduction Program; summaries of technical reports, v. 25: U.S. Geological Survey Open-File Report 88-16.

OF 88-434 Jacobson, M.L., compiler, 1988, National Earthquake Hazards Reduction Program; summaries of technical reports, v. 26: U.S. Geological Survey Open-File Report 88-434.

Aleinikoff, J.N., Plafker, George, and Nokleberg, W.J., 1988, Middle Pennsylvanian plutonic rocks along the southern margin of the Wrangellia terrane: C1016, p. 110-113.

Allison, C.W., 1988, Paleontology of Late Proterozoic and Early Cambrian rocks of east-central Alaska: U.S. Geological Survey Professional Paper 1449, 50 p., 18 pls.

Alpha, T.R., Detterman, J.S., and Morley, J.M., 1988, Atlas of oblique maps; A collection of landform portrayals of selected areas of the world: U.S. Geological Survey Miscellaneous Investigations Series I-1799, 137 p. [Alaska and North Pacific: p. 5-38].

Arbogast, B.F., Madden, Dawn, Hoffman, J.D., and O'Leary, R.M., 1987, Analytical results and sample locality map of stream-sediment, moraine sediment, and heavy-mineralconcentrate samples from the Anchorage quadrangle, south-central Alaska: U.S. Geological Survey Open-File Report 87-151, 175 p., scale 1:250,000, 1 pl.

Bailey, E.A., Lee, G.K., and Light, T.D., 1987, Semiquantitative emission spectrographic analyses of stream-sediment samples collected in the Livengood and western onethird of the Circle $1^{\circ}$ by $3^{\circ}$ quadrangles, Alaska: U.S. Geological Survey Open-File Report 87-264, 74 p., scale 1:250,000.

Baldauf, J.G., and Barron, J.A., 1987, Oligocene marine diatoms recovered in dredge samples from the Navarin basin province, Bering Sea: U.S. Geological Survey Bulletin 1765,17 p.,

Barnes, P.W., and Reimnitz, Erk, 1988, Construction of an arctic barrier island by alternating sea-ice pileup and overwash: C1016, p. 180-182.

Bartsch-Winkler, Susan, 1988, Post-earthquake sedimentation in upper Cook Inlet, Alaska, in Shearer, C.F., ed. and compiler, Minutes of the National Earthquake Prediction Evaluation Council, April 2 and 3, 1987, Seattle, Washington: U.S. Geological Survey Open-File Report 88-37, p. 204-205.

Bartsch-Winkler, Susan, and Schmoll, H.R., 1988, Earthquakecaused sedimentary couplet in the upper Cook Inlet region, in Shearer, C.F., ed. and compiler, Minutes of the National Earthquake Prediction Evaluation Council, April 2 and 3, 1987, Seattle, Washington: U.S. Geological Survey Open-File Report 88-37, p. 206-209.

Bauer, R.L., Himmelberg, G.R., Brew, D.A., and Ford, A.B., 1988, Relative timing of porphyroblast growth, foliation development, and ductile shear in pelitic metamorphic rocks from the Juneau area, southeastern Alaska: C1016, p. 138-142.

Beavan, John, 1988, Crustal deformation measurements in the Shumagin seismic gap: OF 88-16, p. 213-217.

1988, Crustal deformation measurement in the Shumagin seismic gap, Alaska: OF 88-434, p. 191-195.

Bennett, G.J., and Church, S.E., 1987, Mineralogy and sample locality map of the nonmagnetic heavymineral-concentrate samples from the Mt. Katmai quadrangle, and portions of the Naknek, Afognak, and Iliamna quadrangles, Alaska: U.S. Geological Survey Open-File Report 87-615, 39 p., scale 1:250,000, 1 pl.

Bennett, G.J., Gray, J.E., and Taylor, C.D., 1988, Mineralogy 
and sample locality map of the nonmagnetic, heavymineral-concentrate samples, Iditarod quadrangle, Alaska: U.S. Geological Survey Open-File Report 88-32, 37 p., scale 1:250,000, 1 pl.

Berg, H.C., Brew, D.A., and Nokleberg, W.J., with contributions from J. Dunbier and others, 1987, Significant metalliferous lode deposits of southeastern Alaska: B1786, p. 59-72.

Berg, H.C., Elliott, R.L., and Koch, R.D., 1988, Geologic map of the Ketchikan and Prince Rupert quadrangles, southeastern Alaska: U.S. Geological Survey Miscellaneous Investigations Series Map I-1807, 27 p., scale 1:250,000, $1 \mathrm{pl}$.

Bigelow, B.B., 1988, Hydrologic data collection activities in the Solomon Gulch basin near Valdez, Alaska: U.S. Geological Survey Open-File Report 88-719, 15 p.

Billington, Selena, and Kisslinger, Carl, 1986, Central Aleutian Islands seismic network: OF 87-63, p. 14-17.

1988, Central Aleutian Islands seismic network: OF 88-16, p. 8-13.

Bird, K.J., Magoon, L.B., and Molenaar, C.M., 1988, Petroleum geology of the northern part of the Arctic National Wildlife Refuge, northeastern Alaska [abs.]: C1025, p. 4.

Bliss, J.D., Brosgé, W.P., Dillon, J.T., Cathrall, J.B., and Dutro, J.T., Jr., 1988, Maps and descriptions of lode and placer deposits, prospects, and occurrences in the Wiseman $1^{\circ}$ by $3^{\circ}$ quadrangle, Alaska: U.S. Geological Survey OpenFile Report 88-293, 53 p., scale 1:250,000, 2 pls.

Blodgett, R.B., Rohr, D.M., Harris, A.G., and Jia-yu, Rong, 1988, A major unconformity between Upper Ordovician and Lower Devonian strata in the Nanook Limestone, Shublik Mountains, northeastern Brooks Range: C1016, p. 18-23.

Blodgett, R.B., Zhang, Ning, Ormiston, A.R., and Weber, F.R., 1988, A Late Silurian age determination for the limestone of the Lost Creek Unit, Livengood C-4 quadrangle, east-central Alaska: C1016, p. 54-56.

Bohn, Diedra, ed., [1988], 1987 annual report on Alaska's mineral resources: U.S. Geological Survey Circular 1012 , $59 \mathrm{p}$.

Brew, D.A., 1988, Latest Mesozoic and Cenozoic igneous rocks of southeastern Alaska-a synopsis: U.S. Geological Survey Open-File Report 88-405, 53 p.

Brew, D.A., and Karl, S.M., 1988, A re-examination of the contacts and other features of the Gravina belt, southeastern Alaska: C1016, p. 143-146.

Brew, D.A., Karl, S.M., and Miller, J.W., 1988, Megafossils (Buchia) indicate Late Jurassic age for part of Kelp Bay Group on Baranof Island, southeastern Alaska: C1016, p. 147-149.

Brockman, S.R., Espinosa, A.F., and Michael, J.A., 1988, Catalog of intensities and magnitudes for earthquakes in Alaska and the Aleutian Islands-1786-1981: U.S. Geological Survey Bulletin 1840, 199 p.

Brouwers, E.M., and Marincovich, Louie, Jr., 1988, Ostracode and molluscan assemblages from the late Neogene Nuwok Member of the Sagavanirktok Formation, North Slope: C1016, p. 24-26.

Bruns, T.R., 1988, Petroleum geology and hydrocarbon plays of the Gulf of Alaska onshore province: A report for the National Hydrocarbon Assessment Program: U.S. Geo- logical Survey Open-File Report 88-450-J, 30 p.

1988, Petroleum potential of southeastern Alaska: A report for the National Hydrocarbon Assessment Program: U.S. Geological Survey Open-File Report 88-450I, 8 p.

Bugliosi, E.F., 1988, Hydrologic reconnaissance of the Chilkat River basin, southeast Alaska, with special reference to the Alaska Chilkat Bald Eagle Preserve: U.S. Geological Survey Water-Resources Investigations Report 88-4023, $38 \mathrm{p}$.

Bundtzen, T.K., and Nokleberg, W.J., with contributions from J.Y. Foley and others, 1987, Significant metalliferous lode deposits, west-central Alaska: B1786, p. 23-31.

Carter, L.D., Brouwers, E.M., and Marincovich, Louie, Jr., 1988, Nearshore marine environments of the Alaskan Beaufort Sea during deposition of the Flaxman Member of the Gubik Formation: C1016, p. 27-30.

Carter, L.D., and Galloway, J.P., 1988, Engineering-geologic maps of northern Alaska, Ikpikpuk River quadrangle: U.S. Geological Survey Open-File Report 88-375, 19 p., scale $1: 250,000,2$ pls.

Carter, L.M.H., ed., 1988, USGS research on energy resources1988, program and abstracts: U.S. Geological Survey Circular 1025,70 p. [V.E. McKelvey Forum on Mineral and Energy Resources].

Case, J.E., Detterman, R.L., Wilson, F.H., Chuchel, B.A., and Yount, M.E., 1988, Maps showing aeromagnetic survey and geologic interpretation of the Ugashik and part of the Karluk quadrangles, Alaska: U.S. Geological Survey Miscellaneous Field Studies Map MF-1539-D, 12 p., scale $1: 250,000,2$ pls.

Cathrall, J.B., McDanal, S.K., VanTrump, George, Mosier, E.L., and Tripp, R.B., 1988, Analytical results, geochemical signatures, mineralogical data, and sample locality map of lode gold, placer gold, and heavy-mineral concentrates from the Tolovana mining district, Livengood quadrangle, Alaska: U.S. Geological Survey Open-File Report 88-578, 32 p.

Çelebi, M., compiler, 1988, Report on recommended list of structures for seismic instrumentation in Alaska: U.S. Geological Survey Open-File Report 88-278, 49 p.

Childs, J.R., Magistrale, H.W., and Cooper, A.K., 1987, Freeair gravity anomaly map of the central and northern Bering Sea: U.S. Geological Survey Geophysical Investigations Series Map GP-971, scale 1:1,000,000.

1987, Free-air gravity anomaly map of the Umnak Plateau region, southeastern Bering Sea: U.S. Geological Survey Geophysical Investigations Series Map GP-970, scale 1:1,000,000.

Church, S.E., Delevaux, M.H., and Gray, J.E., 1987, Pb-isotope data base for sulfides from Alaska, March 1987: U.S. Geological Survey Open-File Report 87-259, 44 p.

Church, S.E., Frisken, J.G., Detra, D.E., and Willson, W.R., 1988, Geochemical map showing the distribution of selected elements determined in stream sediments from the Ugashik, Bristol Bay, and western Karluk quadrangles, Alaska: U.S. Geological Survey Miscellaneous Field Studies Map MF-1539-F, scale 1:250,000.

Church, S.E., VanTrump, George, Jr., Motooka, J.M., and Frisken, J.G., 1988, Analytical data and sample locality map for aqua-regia leachates of stream sediments ana- 
lyzed by ICP from the Port Moller, Stepovak Bay, and Simeonof Island quadrangles, Alaska; U.S. Geological Survey Open-File Report 88-437, 47 p., scale 1:250,000, $1 \mathrm{pl}$.

Collett, T.S., and Bird, K.J., 1988, Hydrocarbon distribution in the Cretaceous-Tertiary Sagavanirktok Formation, North Slope [abs.]: C1025, p. 9-10.

Collett, T.S., Bird, K.J., Kvenvolden, K.A., and Magoon, L.B., 1988, Geologic interrelations relative to gas hydrates within the North Slope of Alaska: U.S. Geological Survey Open-File Report 88-389, 150 p.

Combellick, R.A., and Reger, R.D., 1988, Evaluation of Holocene subsidence events of Cook Inlet estuarine flats near Anchorage, Alaska, as a basis for assessing seismic hazards in south-central Alaska: OF 88-434, p. 463-464.

Cunningham, K.I., and Roberts, A.A., 1988, Helium and C1-C3 hydrocarbon concentrations in permafrost ice, Marsh Creek area, Arctic National Wildlife Refuge, Alaska: U.S. Geological Survey Open-File Report 88-1, 33 p.

Davis, A.S., Pickthorn, L.-B.G., Vallier, T.L., and Marlow, M.S., 1988, Petrology, geochemistry and K-Ar ages of volcanic-arc rocks dredged from the continental margin in the Bering Sea: U.S. Geological Survey Open-File Report 88-34, 1 v.

Detterman, R.L., 1988, Mesozoic biogeography of southern Alaska with implications for the paleogeography: U.S. Geological Survey Open-File Report 88-662, 27 p. 1988, Sections of Sadlerochit Group and Siksikpuk Formation(?) from Arctic and Table Mountains quadrangles, Alaska: U.S. Geological Survey Open-File Report 88-370, 1 pl.

Detterman, R.L., and Miller, J.W., 1988, Lithofacies fence diagram of the Upper Mesozoic, Alaska Peninsula: U.S. Geological Survey Open-File Report 88-668, scale $1: 250,000,3$ sheets.

Dickey, C.F., and Karl, S.M., 1988, Geological bibliography of the Sitka quadrangle, southeastern Alaska: U.S. Geological Survey Open-File Report 88-645, 36 p.

Dijkmans, J.W.A., Galloway, J.P., and Koster, E.A., 1988, Grain-size and mineralogy of eolian and fluvial sediment in the central Kobuk valley, northwestern Alaska: U.S. Geological Survey Open-File Report 88-369, 21 p.

Dover, J.H., and Miyaoka, R.T., 1988, Reinterpreted geologic map and fossil data, Charley River quadrangle, eastcentral Alaska: U.S. Geological Survey Miscellaneous Field Studies Map MF-2004, scale 1:250,000, 2 sheets.

Dumoulin, J.A., 1987, Sandstone composition of the Valdez and Orca Groups, Prince William Sound, Alaska: U.S. Geological Survey Bulletin 1774, 37 p.

1988, Stromatolite- and coated-grain-bearing carbonate rocks of the western Brooks Range: C1016, p. 31-34

Dumoulin, J.A., and Harris, A.G., 1988, Off-platform Silurian sequences in the Ambler River quadrangle: C1016, p. 35-38.

Eberlein, G.D., and Lanphere, M.A., 1988, Precambrian rocks of Alaska: U.S. Geological Survey Professional Paper 1241-B, 18 p., 1 pl. ["Correlation of Precambrian rocks of the United States and Mexico," edited by J.E. Harrison and Z.E. Peterman].

Edwards, B.D., Bohannon, R.G., Dobson, M.R., and Campbell, J.M., 1988, Cruise report for cruise F3-87-AA, GLO-
RIA survey of the west-central Aleutian Arc and adjacent North Pacific Ocean: U.S. Geological Survey OpenFile Report 88-227, 10 p.

EEZ-Scan Bering Sea and Aleutian Arc Groups, 1988, GLORIA sonographic mosaic of the Bering Sea and the western Aleutian Arc and adjacent North Pacific [abs.]: C1025, p. 14-15.

Erlich, Olga, Motooka, J.M., Church, S.E., Bailey, E.A., Arbogast, B.F., and Willson, W.R., 1988, Analytical data and sample locality map for aqua-regia leachates of stream sediments analyzed by ICP, and emission spectrographic results for both stream sediments and panned concentrates collected in 1985 from the Chandler Lake quadrangle, Alaska: U.S. Geological Survey Open-File Report 88-530, 38 p., scale 1:250,000, 1 pl.

Erlich, Olga, Motooka, J.M., VanTrump, George, Jr., and Church, S.E., 1988, Analytical data and sample locality map for aqua-regia leachates of stream sediments analyzed by ICP from the Mt. Katmai quadrangle, and portions of the Naknek, Afognak, and Iliamna quadrangles, Alaska: U.S. Geological Survey Open-File Report 88-422, 72 p., scale 1:250,000, 1 pl.

Espinosa, A.F., 1986, Seismic hazard studies, Anchorage, Alaska: OF 87-63, p. 490-492.

1988, Seismic hazard studies, Anchorage, Alaska: OF 88-16, p. 491-493.

1988, Seismic hazard studies, Anchorage, Alaska: OF $88-434$, p. $477-479$.

Espinosa, A.F., and Rukstales, K.S., 1988, Geometry of the Benioff zone and mode of subduction beneath southwestern Alaska and the Aleutian Islands: U.S. Geological Survey Miscellaneous Investigations Series Map I1945.

Fisher, M.A., 1988, Petroleum geology of rocks exposed on Kodiak Island, Alaska: A report for the Federal Lands Assessment Program (FLAP): U.S. Geological Survey Open-File Report 88-385, 6 p.

1988, Petroleum geology of the onshore part of Hope and Kotzebue basins, Alaska: A report for the Federal Lands Assessment Program (FLAP): U.S. Geological Survey Open-File Report 88-383, 6 p.

Fogleman, K.A., Stephens, C.D., and Lahr, J.C., 1988, Catalog of earthquakes in southern Alaska for 1985: U.S. Geological Survey Open-File Report 88-31, 112 p.

Ford, A.B., and Brew, D.A., 1988, Major-element geochemistry of metabasalts of the Juneau-Haines region, southeastern Alaska: C1016, p. 150-155.

Foster, D.S., 1988, Quaternary acoustic stratigraphy between the Colville River and Prodhoe [sic] Bay, Beaufort Sea Shelf, Alaska: U.S. Geological Survey Open-File Report 88-276, 108 p., 3 pls.

Frisken, J.G., Church, S.E., Detra, D.E., and Willson, W.R., 1988, Geochemical map showing the distribution of selected elements determined in nonmagnetic heavymineral concentrates from the Ugashik, Bristol Bay, and western Karluk quadrangles, Alaska: U.S. Geological Survey Miscellaneous Field Studies Map MF-1539-G, scale $1: 250,000,2$ sheets.

Frisken, J.G., Church, S.E., and Willson, W.R., 1988, Mineralogical map showing the distribution of selected orerelated minerals identified in nonmagnetic heavy- 
mineral concentrates from the Ugashik, Bristol Bay, and western Karluk quadrangles, Alaska: U.S. Geological Survey Miscellaneous Field Studies Map MF-1539-H, scale 1:250,000.

Frost, T.P., Calzia, J.P., Kistler, R.W., and Vivit, D.V., 1988, Petrogenesis of the Crooked Mountains pluton, Bethel quadrangle: A preliminary report: C1016, p. 126-131.

Galloway, J.P., 1987, A list and index of published radiocarbon dates for Alaska with a bibliography: U.S. Geological Survey Open-File Report 87-517-A, 117 p.

-1987, Radiocarbon date list for Alaska to accompany USGS Open-File Report 87-517-A: U.S. Geological Survey Open-File Report 87-517-B. [5 1/4 inch diskette formatted for IBM-PCs using DOS 2.0 in a standard ASCII format].

-1988, A bibliography of selected geologic and engineering-geologic literature of northern Alaska (Arctic coastal plain and northern foothills): U.S. Geological Survey Open-File Report 88-395, 34 p.

Galloway, J.P., and Hamilton, T.P., 1988, Geologic studies in Alaska by the U.S. Geological Survey during 1987, Introduction: C1016, p. 1.

Gamble, B.M., 1988, Non-placer mineral occurrences in the Solomon, Bendeleben, and southern part of the Kotzebue quadrangles, western Alaska: U.S. Geological Survey Miscellaneous Field Studies Map MF-1838-B, 13 p., scale $1: 250,000,1$ pl.

Gamble, B.M., Harris, E.E., Sutley, S.J., and Walker, K.M., 1988, Analytical results and sample locality map for rock samples from the Solomon, Bendeleben, and southern part of the Kotzebue quadrangles, western Alaska: U.S. Geological Survey Open-File Report 88-266, 118 p., scale $1: 250,000,1 \mathrm{pl}$.

Gamble, B.M., Nokleberg, W.J., and Grybeck, Donald, with contributions from R.P. Ashley and others, 1987, Significant metalliferous lode deposits, Seward Peninsula: B1786, p. 18-22.

Gebert, W.A., Graczyk, D.J., and Krug, W.R., 1987, Average annual runoff in the United States, 1951-80: U.S. Geological Survey Hydrologic Investigations Atlas HA-710.

Gedney, Larry, 1987, Alaska earthquakes, 1983, in Stover, C.W., ed., United States earthquakes, 1983: U.S. Geological Survey Bulletin 1698, p. 125.

Gedney, Larry, and Davies, J.N., 1986, Preliminary seismological investigations of the north-central Alaska earthquake sequences of February and March, 1985: OF 87-63, p. 61-66.

Geist, E.L., Fisher, M.A., and Brocher, T.M., 1988, Availability of deep crustal multichannel seismic reflection data collected for the Trans-Alaska Crustal Transect, southeastern Alaska: U.S. Geological Survey Open-File Report 88-521, 10 p.

Gergen, L.D., Decker, J.E., and Plafker, George, 1988, A comparative petrologic study of sandstone from the Wilber Creek, Cascaden Ridge, and Wickersham units in the Livengood quadrangle: C1016, p. 57-60.

Gergen, L.D., and Plafker, George, 1988, Petrography of sandstones of the Orca Group from the southern TransAlaska Crustal Transect (TACT) route and Montague Island: C1016, p. 156-159.

Glass, R.L., 1987, Ground-water levels in Anchorage, Alaska,
1985: U.S. Geological Survey Open-File Report 87-546, $15 \mathrm{p} ., 1 \mathrm{pl}$. [Number printed on envelope is $87-543-$ an error].

1988, Map showing depth to bedrock, Anchorage, Alaska: U.S. Geological Survey Open-File Report $88-198$, scale $1: 25,000$.

Glass, R.L., and Brabets, T.P., 1988, Summary of water resources data for the Girdwood-Alyeska area, Alaska: U.S. Geological Survey Open-File Report 87-678, 24 p.

Goldfarb, R.J., Gray, J.E., and Tripp, R.B., 1988, Geochemical anomalies in the eastern Katmai region of the Alaska Peninsula: C1016, p. 132-135.

Goldfarb, R.J., Hofstra, A.H., Landis, G.P., and Leach, D.L., 1988, H2S-rich vein-forming fluids at the Sumdum Chief gold mine, southeastern Alaska: C1016, p. 160-163.

Gough, L.P., Severson, R.C., and Shacklette, H.T., 1988, Element concentrations in soils and other surficial materials of Alaska: U.S. Geological Survey Professional Paper 1458,53 p. ["An account of the concentration of 43 chemical elements, ash, and $\mathrm{pH}$ in soil and other unconsolidated regolith samples"].

Gray, J.E., Arbogast, B.F., and Hudson, A.E., 1988, Geochemical results and sample locality map of the stream sediment and nonmagnetic, heavy-mineral-concentrate samples from the Iditarod quadrangle, Alaska: U.S. Geological Survey Open-File Report 88-221, 69 p., scale 1:250,000, 1 pl.

Gray, J.E., Ryder, J.L., Sanzolone, R.F., McHugh, J.B., and Ficklin, W.H., 1988, Analytical data and sample locality map for stream water samples from the Iditarod quadrangle, Alaska: U.S. Geological Survey Open-File Report 88-55, 23 p., scale 1:250,000, 1 pl.

Gray, J.E., Smith, S.C., and Goldfarb, R.J., 1988, Factor analysis of the NURE stream-sediment and lakesediment geochemical data from the Iditarod quadrangle: C1016, p. 86-90.

Grybeck, Donald, Nokleberg, W.J., with contributions from J.C. Barker and others, 1987, Significant metalliferous lode deposits, Brooks Range: B1786, p. 9-17.

Hamilton, T.D., Galloway, J.P., and Koster, E.A., 1988, Late Wisconsin eolian activity and related alluviation, central Kobuk River Valley: C1016, p. 39-43.

Jones, D.L., Coney, P.J., Harms, T.A., and Dillon, J.T., 1988, Interpretive geologic map and supporting radiolarian data from the Angayucham terrane, Coldfoot area, southern Brooks Range, Alaska: U.S. Geological Survey Miscellaneous Field Studies Map MF-1993, scale $1: 63,360$.

Jones, S.H., and Zenone, Chester, 1988, Flood of October 1986 at Seward, Alaska: U.S. Geological Survey WaterResources Investigations Report $87-4278,43$ p., scale $1: 25,000,2$ pls.

Karl, H.A., and Vallier, T.L., 1987, Cruise report for EEZSCAN Cruise F2-87-AA, western Aleutian Arc and adjacent north Pacific, July 28 through Aug. 26, 1987: U.S. Geological Survey Open-File Report 87-643, 6 p.

Karl, S.M., Ager, T.A., Hanneman, Karl, and Teller, S.D., 1988, Tertiary gold-bearing gravel at Livengood, Alaska: C1016, p. 61-63.

Karl, S.M., Johnson, B.R., and Lanphere, M.A., 1988, New $\mathrm{K}$-Ar ages for plutons on western Chichagof Island and 
on Yakobi Island: C1016, p. 164-168.

Kaufman, D.S., Hopkins, D.M., and Calkin, P.E., 1988, Glacial geologic history of the Salmon Lake area, Seward Peninsula: C1016, p. 91-94.

Kelley, J.S., 1988, Preliminary geologic map of the Chandler Lake quadrangle, Alaska: U.S. Geological Survey OpenFile Report 88-42, scale 1:125,000, 2 sheets.

Kelley, J.S., and Bohn, Diedra, 1988, Décollements in the Endicott Mountains allochthon, north-central Brooks Range: C1016, p. 44-47.

Kisslinger, Carl, 1988, Central Aleutian Islands seismic network: OF 88-434, p. 14-20.

1988, Seismicity patterns and the stress state in subduction-type seismogenic zone: OF 88-434, p. 86-92 [Andreanof Islands earthquake of 1986].

Lachenbruch, A.H., Galanis, S.P., Jr., and Moses, T.H., Jr., 1988, A thermal cross section for the permafrost and hydrate stability zones in the Kuparuk and Prudhoe bay oil fields: C1016, p. 48-51.

Lade, P.V., Updike, R.G., and Cole, D.A., 1988, Cyclic triaxial tests of the Bootlegger Cove Formation, Anchorage, Alaska: U.S. Geological Survey Bulletin 1825, 51 p.

Lahr, J.C., Stephens, C.D., and Page, R.A., 1986, Alaska seismic studies: OF 87-63, p. 20-25.

-1988, Alaska seismic studies: OF 88-16, p. 16-24.

Lahr, J.C., Stephens, C.D., Page, R.A., and Fogleman, K.A., 1988, Alaska seismic studies: OF 88-434, p. 21-29.

Lamke, R.D., and Bigelow, B.B., 1988, Floods of October 1986 in southcentral Alaska [revised ed.]: U.S. Geological Survey Open-File Report 87-391, 31 p.

Light, T.D., Lee, G.K., Tripp, R.B., and Bailey, E.A., 1988, Reconnaissance geochemical investigations of the White Mountains National Recreation Area, east-central Alaska: C1016, p. 64-67.

Lipscomb, S.W., 1988, Sediment discharge data for the lower reach of Campbell Creek, Anchorage, Alaska: May to September 1987: U.S. Geological Survey Open-File Report 88-81, 12 p.

Loney, R.A., and Brew, D.A., 1987, Regional thermal metamorphism and deformation of the Sitka Graywacke, southern Baranof Island, southeastern Alaska: U.S. Geological Survey Bulletin 1779, 17 p.

Loney, R.A., and Himmelberg, G.R., 1988, Ultramafic rocks of the Livengood terrane: C1016, p. 68-70.

Lull, J.S., and Plafker, George, 1988, Geochemistry and petrography of lamprophyre dike rocks in the Coast Mountains, southeastern Alaska: C1016, p. 169-173.

Luttrell, G.W., Hubert, M.L., and Murdock, C.R., compilers, 1988, GEONAMES data base of geologic names of the United states through 1986; AK, WA, OR, ID: U.S. Geological Survey Open-File Report 88-44-M, 11 p., one 5 1/4-inch diskette.

Madden, D.J., Arbogast, B.F., O'Leary, R.M., VanTrump, George, Jr., and Silberman, M.L., 1988, Analytical results, statistical analyses, and sample-locality maps of rocks from the Anchorage quadrangle, southern Alaska: U.S. Geological Survey Open-File Report 88-240, 125 p., scales 1:250,000, 1:24,000, 2 pls.

Madden-McGuire, D.J., Silberman, M.L., and Church, S.E., 1988, Geological relationships, K-Ar ages, and isotopic data from the Willow Creek gold mining district, south- ern Alaska [abs.], in Barker, C.E., and Coury, A.B., compilers, Abstracts of U.S. Geological Survey, central region, 1988 poster review; Collected abstracts of selected poster papers presented at scientific meetings: U.S. Geological Survey Open-File Report 88-643, p. 6 [Geological Society of Australia, Abstracts Series no. 23, Extended Abstracts, Poster Programme, Bicentennial Gold Conference, 1988, Melbourne, Australia, v. 1, p. 368-370].

Madison, R.J., McElhone, T.J., and Zenone, Chester, 1987, Alaska groundwater quality: U.S. Geological Survey Open-File Report 87-712, 8 p.

Marlow, M.S., and Wolfe, D.A., panel co-chairpersons, 1988, Workshop 1: Scientific mapping and research to characterize the EEZ-Alaska: U.S. Geological Survey Circular 1018 , p. 39-58 ["Bibliography of U.S.G.S. publications pertinent to the Alaska EEZ," p. 51-58].

Maurer, M.A., and Woods, P.F., 1987, Index to limnological data for south-central Alaska lakes: U.S. Geological Survey Open-File Report 87-529, 146 p.

Mayo, L.R., 1988, Advance of Hubbard Glacier and closure of Russell Fiord, Alaska-environmental effects and hazards in the Yakutat area: C1016, p. 4-16.

1988, Hubbard Glacier near Yakutat, Alaska-the ice damming and breakout of Russell Fiord/Lake, 1986: U.S. Geological Survey Water Supply Paper 2325 (National Water Summary 1986), p. 42-49.

McCammon, R.B., Light, T.D., and Rinehart, C.D., 1988, Mineral resource assessment for part of the White Mountain National Recreation Area: C1016, p. 71-74.

McDanal, S.K., Cathrall, J.B., Mosier, E.L., Antweiler, J.C., and Tripp, R.B., 1988, Analytical results, geochemical signatures, mineralogical data, and sample locality map of placer gold and heavy-mineral concentrates from the Manley Hot Springs, Tofty, Eureka, and Rampart mining districts, Tanana and Livengood quadrangles, Alaska: U.S. Geological Survey Open-File Report 88-443, 54 p.

McGimsey, R.G., and Miller, M.L., 1988, Lahar deposit in the Iditarod volcanics, southwestern Iditarod quadrangle: C1016, p. 95-98.

McGimsey, R.G., Miller, M.L., and Arbogast, B.F., 1988, Paper version of Iditarod quadrangle, Alaska: U.S. Geological Survey Open-File Report 88-421-A, 110 p., scale 1:250,000, $1 \mathrm{pl}$.

McLean, Hugh, 1988, Federal Lands Assessment Program: Alaska Peninsula, Alaska (Province 68): U.S. Geological Survey Open-File Report 87-450-H, 9 p.

Miller, M.L., and Bundtzen, T.K., 1988, Right-lateral offset solution for the Iditarod-Nixon Fork fault, western Alaska: C1016, p. 99-103.

Molenaar, C.M., 1987, Depositional history and seismic stratigraphy of Lower Cretaceous rocks, National Petroleum Reserve, Alaska and adjacent areas [abs.], in Barker, C.E., and Coury, A.B., compilers, Abstracts of the U.S. Geological Survey, central region, 1987, poster review: U.S. Geological Survey Open-File Report 87-608, p. 16 [abstract originally appeared in AAPG Bulletin, 1985, v. 69 , no. 4 , p. 670].

Moore, T.E., and Nokleberg, W.J., 1988, Stratigraphy, sedimentology, and structure of the Wickersham terrane in the Cache Mountain area, east-central Alaska: C1016, p. 
$75-80$.

Morrissey, S.-T., 1986, Tiltmeter and earthquake prediction program in S. California and at Adak, AK: OF 87-63, p. 360-364.

Motooka, J.M., Gray, J.E., Erlich, Olga, and VanTrump, George, Jr., 1988, Analytical data and sample locality map for aqua-regia leachates of stream sediments analyzed by ICP from the Iditarod quadrangle, Alaska: U.S. Geological Survey of 88-290, 63 p., scale 1:250,000, 1 pl.

Motooka, J.M., Smaglik, S.M., Church, S.E., and Bennett, G.J., 1988, Analytical data and sample locality map for aquaregia leachates of stream sediments analyzed by ICP from the Bristol Bay, Ugashik, and western Karluk quadrangles, Alaska: U.S. Geological Survey Open-File Report 88-435, 38 p., scale 1:250,000, 1 pl.

Murphy, J.M., and Patton, W.W., Jr., 1988, Geologic setting and petrography of the phyllite and metagraywacke thrust panel, north-central Alaska: C1016, p. 104-108.

Newberry, R.J., and Brew, D.A., 1988, Alteration zoning and origin of the Alaska-Juneau gold deposit: C1016, p. 174-178.

Newhall, C.G., and Dzurisin, Daniel, 1988, Alaska data, in Historical unrest at large calderas of the world: U.S. Geological Survey Bulletin 1855, v. 2, p. 678-737.

Nielsen, D.C., Douglass, S.L., and Brew, D.A., 1988, Revised geological bibliography of the Juneau Project area, Alaska: U.S. Geological Survey Open-File Report 88-424, 51 p. [supersedes OF 84-564; covers the Juneau, Taku River, Atlin, and part of the Skagway quadrangles].

Nokleberg, W.J., with contributions from T.K. Bundtzen and others, 1987, Significant metalliferous lode deposits, southern Alaska: B1786, p. 47-58.

Nokleberg, W.J., Bundtzen, T.K., Berg, H.C., Brew, D.A., Grybeck, Donald, Robinson, M.S., Smith, T.E., and Yeend, Warren, 1987, Significant metalliferous lode deposits and placer districts of Alaska: U.S. Geological Survey Bulletin 1786, 104 p., 2 pls. [introduction by same authors and with same title on p. 1-8].

1988, Metallogeny and major mineral deposits of Alaska: U.S. Geological Survey Open-File Report 88-73, 97 p., 2 pls.

Odum, J.K., Yehle, L.A., Schmoll, H.R., Gardner, C.A., and Dearborn, L.L., 1988, Lithological, geotechnical properties analysis, and geophysical log interpretation of U.S. Geological Survey drill holes 1C-79, 2C-80, CW81-2, and CE82-1, Tyonek Formation, Upper Cook Inlet region, Alaska: U.S. Geological Survey Bulletin 1835, 27 p.

Ovenshine, A.T., Lawson, D.E., and Bartsch-Winkler, Susan, 1988, The Placer River Silt; an intertidal deposit caused by the 1964 Alaska earthquake, in Shearer, C.F., ed. and compiler, Minutes of the National Earthquake Prediction Evaluation Council, April 2 and 3, 1987, Seattle, Washington: U.S. Geological Survey Open-File Report 88-37, p. 210-221.

Pallister, J.S., and Carlson, Christine, 1988, Bedrock geologic map of the Angayucham Mountains, Alaska: U.S. Geological Survey Miscellaneous Field Studies Map MF2024, scale 1:63,360, 1 sheet.

Phillips, R.L., 1988, Measured sections, paleoenvironments, and sample locations near Ocean Point, Alaska: U.S.
Geological Survey Open-File Report 88-40.

Phillips, R.L., and Colgan, M.W., 1988, Sea-floor feeding traces of gray whales and walrus in the northeast Chukchi Sea: C1016, p. 183-186.

Phillips, R.L., Pickthorn, L.B.G., and Rearic, D.M., 1988, Late Cretaceous sediments from the northeast Chukchi Sea: C1016, p. 187-189.

Plafker, George, 1987, Application of marine-terrace data to paleoseismic studies, in Crone, A.J., and Omdahl, E.M., eds., Directions in paleoseismology: U.S. Geological Survey Open-File Report 87-673, p. 146-156 [examples from Middleton Island and other Alaskan places].

Rearic, D.M., Williams, S.R., Carlson, P.R., and Hall, R.K., 1988, Acoustic evidence for gas-charged sediment in the abyssal Aleutian basin, Bering Sea, Alaska: U.S. Geological Survey Open-File Report 88-677, 41 p.

Reimnitz, Erk, and Barnes, P.W., 1988, Evidence for sea-ice impact on Icy Reef, Beaufort Sea coast: C1016, p. 190-192.

Reimnitz, Erk, Graves, S.M., and Barnes, Peter, 1988, Beaufort Sea coastal erosion, sediment flux, shoreline evolution, and the erosional shelf profile: U.S. Geological Survey Miscellaneous Investigations Series Map I-1182-G, 22 p., $1 \mathrm{pl}$.

Richter, D.H. Schmoll, H.R., and Bove, D.J., 1988, Source of the Sanford volcanic debris flow, south-central Alaska: C1016, p. 114-116.

Roberts, S.B., 1988, Coal quality and distribution in Upper Cretaceous and Tertiary rocks, east-central North Slope, Alaska [abs.]: C1025, p. 53-54.

Roberts, S.B., Clark, A.C., and Carey, M.A., 1988, Analyses of seven core samples from two Tertiary coal beds in the Sagwon Member of the Sagavanirktok Formation, North Slope, Alaska: U.S. Geological Survey Open-File Report 88-21, 6 p.

Roehler, H.W., 1987, Depositional environments of coalbearing and associated formations of Cretaceous age in the National Petroleum Reserve in Alaska: U.S. Geological Survey Bulletin 1575, 16 p.

Rose, S.C., Pickthorn, W.J., and Goldfarb, R.J., 1988, Gold mineralization by metamorphic fluids in the Chandalar district, southern Brooks Range-fluid inclusion and oxygen-isotopic evidence: C1016, p. 81-84.

Schmidt, J.M., and Allegro, G.L., 1988, Mineral occurrence and indicators in the Baird Mountains quadrangle, northwestern Alaska: U.S. Geological Survey Miscellaneous Field Studies Map MF-1992, 19 p., scale 1:250,000, 1 pl.

Smith, T.E., Robinson, M.S., and Nokleberg, W.J., with contributions from T.K. Bundtzen and others, 1987, Significant metalliferous lode deposits, east-central Alaska: B1786, p. $32-40$.

Snyder, E.F., 1988, Location maps and list of U.S. Geological Survey reports on water resources in Alaska, 1950 to 1988: U.S. Geological Survey Open-File Report 88-344, $35 \mathrm{p}$.

Stanley, R.G., 1988, Hydrocarbon source potential and thermal maturity of the Sanctuary Formation (Middle Miocene), northern foothills of the Alaska Range: C1016, p. 117-120.

Stephens, C.D., Page, R.A., Fogleman, K.A., and Lahr, J.C., 1987, Southern Alaska seismicity, 1983, in Stover, C.W., 
United States earthquakes, 1983: U.S. Geological Survey Bulletin 1698, p. 127-130.

Still, P.J., and Brunett, J.O., 1987, Ground-water levels in Alaska, water year 1984: U.S. Geological Survey OpenFile Report 87-230, 308 p.

Stover, C.W., 1988, Alaska, in United States earthquakes, 1984: U.S. Geological Survey Bulletin 1862, p. 10-18.

Stricker, G.D., and Affolter, R.H., 1988, Eocene lava and epigene mineralization alter Alaska's thickest known coal deposit [abs.]: C1025, p. 59-60 [Death Valley, Seward Peninsula].

Stricker, G.D., Brownfield, M.E., Yehle, L.A., and Wolfe, J.A., 1988, Mineralogy and stage assignment of some Tertiary coal from the Tikishla Park drill hole, Anchorage, Alaska: C1016, p. 121-123.

Taber, John, 1986, Seismic monitoring of the Shumagin seismic gap, Alaska: OF 87-63, p. 39-40.

1988, Seismic monitoring of the Shumagin seismic gap, Alaska: OF 88-16, p. 40-41.

1988, Seismic monitoring of the Shumagin seismic gap, Alaska: OF 88-434, p. 44-45.

Taber, John, and Huang, Paul, 1988, Analysis of seismic data from the Shumagin seismic gap, Alaska: OF 88-434, p. 259-262.

Taber, John, and Jacob, K.H., 1986, Analysis of seismic data from the Shumagin seismic gap, Alaska: OF 87-63, p. 260-261.

1988, Analysis of seismic data from the Shumagin seismic gap, Alaska: OF 88-16, p. 293-295.

Taber, John, Luchman, M.A., and Rosen, S., 1987, Earthquake monitoring in the Shumagin seismic gap and eastern Aleutians, Alaska, 1983, in Stover, C.W., ed., United States earthquakes, 1983: U.S. Geological Survey Bulletin 1698 , p. $125-127$.

1988, Eastern Aleutian seismicity [abs.]: U.S. Geological Survey Bulletin 1862, p. 135.

Townshend, J.B., and others, 1988, Preliminary geomagnetic data, College Observatory, Fairbanks, Alaska: U.S. Geological Survey Open-File Report 88-300 A-L. [Each monthly report has its own letter designation; authorship and number of pages vary.]

U.S. Geological Survey, 1987, Alaska interim land cover mapping program: Data Users Guide 7, 18 p. [Data Users Guides 1-7 replace USGS Circulars 895B-G].

1987, Arctic Alaska vegetation and land cover, 1981: Land Use and Land Cover Map L-0207, scale 1:250,000. 1987, Beechey Point, Alaska, vegetation and land cover: Land Use and Land Cover Map L-0211, scale 1:250,000. 1987, Hydrologic unit map - 1987, State of Alaska: scale $1: 2,500,000$.

1987, Valdez, Alaska, vegetation and land cover: Land Use and Land Cover Map L-0209, scale 1:250,000.

1988, Aeromagnetic map of part of the Middleton Island quadrangle and vicinity, Alaska: Open-File Report 88-505, scale 1:250,000.

1988, Dillingham, Alaska, vegetation and land cover, 1974-77: Land Use and Land Cover Map L-210, scale $1: 250,000$

1988, Fairbanks, Alaska, vegetation and land cover, 1977-79: Land Use and Land Cover Map L-208, scale $1: 250,000$.
1988, Meade River, Alaska, vegetation and land cover, 1975-76: Land Use and Land Cover Map L-205, scale $1: 250,000$.

1988, Mt. Michelson, Alaska, vegetation and land cover, 1976-81: Land Use and Land Cover Map L-206, scale $1: 250,000$.

Vaill, J.E., and others, 1988, Water resources data, Alaska, water year 1987: U.S. Geological Survey Water-Data Report AK-87-1, 284 p.

Van Maanen, J.L., Lamke, R.D., Still, P.J., Vaill, J.E., and Bigelow, B.B., 1988, Water resources data, Alaska, water year 1986: U.S. Geological Survey Water-Data Report AK-86-1, 330 p.

Van Maanen, J.L., and Solin, G.L., 1988, Hydraulic and channel characteristics of selected streams in the Kantishna Hills area, Denali National Park and Preserve, Alaska, 1982-84: U.S. Geological Survey Open-File Report 88-325, $105 \mathrm{p}$.

VanTrump, George, Jr., Motooka, J.M., Erlich, Olga, and Tompkins, M.L., 1988, Analytical data and sample locality map for aqua-regia leachates of stream sediments analyzed by ICP from the Chignik and Sutwik Island quadrangles, Alaska: U.S. Geological Survey Open-File Report 88-512, 40 p., scale 1:250,000, 1 pl.

Weber, F.R., McCammon, R.B., Rinehart, C.D., Light T.D., and Wheeler, K.L., 1988, Geology and mineral resources of the White Mountains National Recreation Area, east-central Alaska: U.S. Geological Survey Open-File Report 88-284, 2 v.

Wheeler, K.L., and Weber, F.R., 1988, Bibliography of selected references on the geology of the Livengood quadrangle, east-central Alaska: U.S. Geological Survey Open-File Report 88-203, 79 p.

White, E.R., 1988, Reports about Alaska in non-USGS publications released in 1987 which include USGS authors: C1016, p. 201-207.

-1988, Reports about Alaska in USGS publications released in 1987: C1016, p. 194-200.

Wilson, F.H., Anderson, G.L., Bundtzen, T.K., and Nokleberg, W.J., with contributions from D.P. Cox and others, 1987, Significant metalliferous lode deposits, Aleutian Islands and Alaska Peninsula: B1786, p. 41-46.

Wilson, F.H., Harris, E.E., and Bailey, E.A., 1987, Preliminary analytical results and sample locality map for rock samples collected in 1985 and 1986, Port Moller and Stepovak Bay quadrangles, Alaska: U.S. Geological Survey Open-File Report 87-497, 44 p., scale 1:250,000, 1 pl.

Yeend, Warren, Bundtzen, T.K., and Nokleberg, W.J., 1987, Significant placer districts of Alaska: B1786, p. 73-82.

Yeend, Warren, Kaufman, D.S., and Till, A.B., 1988, Placer gold of the Solomon, Bendeleben, and southern part of the Kotzebue quadrangles, western Alaska: U.S. Geological Survey Miscellaneous Field Studies Map MF-1838C, scale $1: 250,000$.

Yehle, L.A., and Schmoll, H.R., 1988, Surficial geologic map of the Anchorage B-7 SE quadrangle, Alaska: U.S. Geological Survey Open-File Report 88-381, 19 p., scale $1: 25,000,2$ pls.

Zayatz, M.R., Thompson, W.B., Bailey, E.A., Sutley, S.J., Folger, P.F., Karl, S.M., and Schmidt, J.M., 1988, Analytical results and sample locality maps of mineralized 
and unmineralized rock samples from the Baird Mountains quadrangle, Alaska: U.S. Geological Survey OpenFile Report 88-256-A, 159 p., scale 1:250,000, 2 pls. 1988, Analytical results and sample locality maps of mineralized and unmineralized rock samples from the
Baird Mountains quadrangle, Alaska: U.S. Geological Survey Open-File Report 88-256-B, 26 p.

Zenone, Chester, 1988, U.S. Geological Survey ground-water studies in Alaska: U.S. Geological Survey Open-File Report 88-122, 2 p. 


\title{
Reports About Alaska in Non-USGS Publications Released in 1988 that Include USGS Authors
}

\author{
Compiled by Ellen R. White
}

[Some reports dated 1987 did not become available until 1988; they are included in this listing. USGS authors are marked by asterisks $\left.\left({ }^{*}\right)\right]$.

\section{ABBREVIATIONS}

AGS Petroleum geology of the 1002 area, Arctic National Wildlife Refuge coastal plain, Alaska, Seminar, Anchorage, Alaska, 1987: Alaska Geological Society, Abstracts and Programs, no p.

ASC Alaska's Resources, Alaska's Future: Alaska Science Conference, 38th, Arctic Science Conference, 1987, Proceedings [American Association for the Advancement of Science, Arctic Division].

Eos $\quad$ Eos (American Geophysical Union Transactions), v. 69, no. 44.

FIR Roedder, Edwin, ed., 1987, Fluid Inclusion Research, v. 20.

Geoexpo Elliott, I.L., and Smee, B.W., eds., 1987, Geoexpo/86; exploration in the North American Cordillera: Rexdale, Ontario, Canada, Association of Exploration Geochemists, 220 p.

GSA Geological Society of America Abstracts with Programs, 1988, v. 20, no. 7.

HVO Hawaii Symposium on How Volcanoes Work (Diamond Jubilee, 1912-1987): Hilo, U.S. Geological Survey, Hawaii Volcano Observatory, Abstract Volume.

IUGG International Union of Geodesy and Geophysics (IUGG), General Assembly, 19th, Vancouver, British Columbia, Canada, 1987, Abstracts.

Placer 1986 Burton, P.J., and Berg, H.C., compilers, 1988, Placer mining: Yesterday, today, tomorrow: Annual Alaska Conference on Placer Mining, 8th, Fairbanks, 1986, Proceedings.

Placer 1987 Albanese, Mary, and Campbell, Bruce, compilers [1988], Placer mining-jobs for Alaska: Annual Alaska Conference on Placer Mining, 9th, Fairbanks, 1987, Proceedings, 315 p.

*Ager, T.A., and Kaufman, Darrell, 1987, Early Eocene sporomorph assemblages from Death Valley, Seward Peninsula, western Alaska [abs.]: Palynology, v. 11, p. 217.

*Ager, T.A., and *Shaw, E.G., 1987, Postglacial pollen record from Circle Lake, Kachemak Bay, south-central Alaska [abs.]: Palynology, v. 11, p. 217-218.

*Arth, J.G., *Barker, Fred, and *Stern, T.W., 1988, Coast batholith and Taku plutons near Ketchikan, Alaska: Petrography, geochronology, geochemistry, and isotopic character: American Journal of Science, v. 288-A, (Wones volume), p. 461-489.

*Barker, Fred, and Arth, J.G., 1988, Nature of the Coast batholith, southeastern Alaska: Are there Archean analogs? [abs.]: Geological Society of India Journal, v. 31, no. 1, p. $12-13$.

*Barker, Fred, Jones, D.L., Budahn, J.R., and Coney, P.J., 1988, Ocean plateau-seamount origin of basaltic rocks, Angayucham terrane, central Alaska: Journal of Geology, v. 96 , no. 3 , p. $368-374$.

*Barnes, D.F., and *Jachens, R.C., 1988, Features of the new isostatic gravity map of Alaska [abs.]: GSA, p. 400.

*Bartsch-Winkler, Susan, 1988, Cycle of earthquake-induced aggregation and related tidal channel shifting, upper Turnagain Arm, Alaska, USA: Sedimentology, v. 35, no.
4, p. $621-628$

Beaudoin, B.C., and *Fuis, G.S., 1988, Crustal structure of Yukon-Tanana uplands, central Alaska, from refraction/wide-angle reflection seismic data, TACT 1987 [abs.]: Eos, p. 1457.

*Bird, K.J., and *Bader, J.W., 1987, Regional geologic setting of the Arctic National Wildlife Refuge, Alaska, and the history of petroleum exploration in adjacent areas [abs.], in AGS.

${ }^{*}$ Bird, K.J., *Dolton, G.L., ${ }^{*}$ Crovelli, R.A., Callahan, J.E., Brougham, G.W., and Bascle, R.J., 1987, Assessment of oil and gas resources in the coastal plain of the Arctic National Wildlife Refuge, Alaska [abs.], in AGS.

*Bird, K.J., *Magoon, L.B., and *Molenaar, C.M., 1988, Petroleum geology of northern part of Arctic National Wildlife Refuge, northeastern Alaska [abs.]: American Association of Petroleum Geologists Bulletin, v. 72, no. 2, p. $162-163$.

Biswas, N.N., Tytgat, G., *Page, R.A., and *Fogleman, K.A., 1988, Earthquake cluster beneath Hiamna Volcano in Alaska [abs.]: Eos, p. 1317.

*Bohannon, R.G., *Vallier, T.L., and *Karl, H.A., 1988, Geology of the Pacific and Kula plates south of the western Aleutian arc: Evidence from GLORIA, seismic- 
reflection, gravity and magnetic data [abs.]: GSA, p. 128.

*Booth, D.B., 1987, Timing and processes of deglaciation along the southern margin of the Cordilleran ice sheet, in Ruddiman, W.F., and Wright, H.E., Jr., eds., North America and adjacent oceans during the last deglaciation: Geological Society of America, Geology of North America, v. K-3, p. 71-90 [one of the Decade of North American Geology Project synthesis volumes].

*Brew, D.A., 1988, The plate-tectonic setting of Glacier Bay National Park and Preserve and of Admiralty Island National Monument, southeastern Alaska, in Glacier Bay Science Symposium, 2d, 1988, Program: U.S. National Park Service, Science Publications Office, p. 7.

${ }^{*}$ Brew, D.A., and *Karl, S.M., 1988, A reexamination of the contacts and other features of the Gravina belt, southeastern Alaska [abs.]: GSA, p. 111.

${ }^{*}$ Brewer, M.C., 1987, Surficial geology, permafrost, and physical processes [abs.], in AGS.

Brigham-Grette, Julie, and *Carter, L.D., 1988, Marine transgressions during the last interglacial/glacial transition along the Arctic Coast of northern Alaska [abs.]: GSA, p. 4.

*Brouwers, E.M., 1988, Late Maestrichtian and Danian faunas from northern Alaska: Reconstructions of environment and biogeography [abs.]: GSA, p. 371.

*Carlson, P.R., *Bruns, T.R., *Fisher, M.A., *Rearic, D.M., and Parson, L.M., 1988, Effect of subduction on morphology and sediment transport on northern Gulf of Alaska margin, as imaged by GLORIA [abs.]: GSA, p. 129.

*Church, S.E., *Gray, J.E., *Delevaux, M.H., and Lehuray, A.P., 1987, Pb-isotope signatures of DevonianMississippian massive sulphide deposits in Alaska and their significance to mineral exploration, in Geoexpo, $\mathrm{p}$. 132-141.

*Collett, T.S., 1988, Internal characteristics of ice-bearing permafrost on the North Slope of Alaska [abs.]: Eos, p. 1210.

Crowe, D.E., *Nelson, Steven, Brown, Philip, and *Shanks, W.C., 1988, Stable isotope and fluid inclusion investigation of massive sulfide deposits, Orca and Valdez Groups, Alaska: Evidence for syngenetic sulfide deposition [abs.]: Geological Society of America Abstracts with Programs, v. 20, no. 3, p. 153.

*Dalrymple, G.B., *Clague, D.A., *Vallier, T.L., and Menard, H.W., 1987, Complex origin of volcanic chains in the Gulf of Alaska [abs.], in HVO, p. 51.

*Dalrymple, G.B., *Clague, D.A., *Vallier, T.L., and *Menard, H.W., 1987, ${ }^{40} \mathrm{Ar} /{ }^{39} \mathrm{Ar}$ age, petrology, and tectonic significance of some seamounts in the Gulf of Alaska, in Keating, B.H., Fryer, Patricia, Batiza, Rodey, and Boehlert, G.W., eds., Seamounts, islands, and atolls: American Geophysical Union Geophysical Monograph 43, p. 297-315, 2 microfiche.

Davies, J.N., Taber, John, *Miller, T.P., *Power, John, and *Yount, M.E., 1988, Seismicity and geology of Mt. Dutton, a volcano near the tip of the Alaska Peninsula [abs.]: Eos, p. 1507.

*Dickinson, K.A., 1988, Diagenesis and uranium mineralization in Kootznahoo Formation, southeastern Alaska [abs.]: American Association of Petroleum Geologists
Bulletin, v. 72 , no. 7 , p. $868-869$.

1988, Paleolimnology of Lake Tubutulik, an ironmeromictic Eocene lake, eastern Seward Peninsula, Alaska: Sedimentary Geology, v. 54, no. 4, p. 303-320.

*Dumoulin, J.A., 1988, Sandstone petrographic evidence and the Chugach-Prince William terrane boundary in southern Alaska: Geology, v. 16, no. 5, p. 456-460.

*Dutro, J.T., Jr., 1988, Comment, and Oldow, J.S., Avé Lallemant, H.G., Julian, F.E., and Seidensticker, C.M., 1988, Reply on "Ellesmerian(?) and Brookian deformation in the Franklin Mountains, northeastern Brooks Range, Alaska, and its bearing on the origin of the Canada Basin": Geology, v. 16, no. 1, p. 89-90.

Ekström, G., and *Engdahl, E.R., 1987, Source mechanisms and locations of earthquakes in the Andreanof Islands region [abs.], in IUGG, v. 1, p. 289.

1988, Earthquake slip vectors and a model of plate interaction in the Aleutian Islands subduction zone [abs.]: Eos, p. 1438.

*Engdahl, E.R., Billington, S., and Kisslinger, C., 1987, Assessment of teleseismically recorded seismicity before and after the May 7, 1986, Andreanof Islands earthquake [abs.], in IUGG, v. 1, p. 276.

*Engdahl, E.R., and Gubbins, D., 1987, Simultaneous travel time inversion for earthquake location and subduction zone structure in the central Aleutian Islands: Journal of Geophysical Research, v. 92, no. B13, p. 13,855-13,862.

*Engdahl, E.R., Taber, J.J., and Billington, S., 1988, Seismicity of the Aleutian arc [abs.]: Seismological Research Letters, v. 59 , no. 1 , p. 16.

*Erlich, E.I., [1988], The nature of island-arc systems and geotectonic regimes in Alaska, in Placer 1987, p. 155-167.

${ }^{*}$ Fisher, M.A., *Nokleberg, W.J., *Labson, V.F., *Stanley, W.D., and *Brocher, T.M., 1988, Deep crustal structure of the Alaska Range, Alaska, from coincident seismic reflection and magneto-telluric observations [abs.]: Eos, p. $1452-1453$.

*Ford, A.B., and *Brew, D.A., 1988, The Douglas Island volcanics; basaltic-rift-not andesitic-arc-volcanism of the "Gravina-Nutzotin belt," northern southeastern Alaska [abs.]: GSA, p. 111.

*Frederiksen, N.O., 1987, Reconnaissance biostratigraphy of the Expressipollis and oculata pollen groups in Campanian and Maastrichtian rocks of the North Slope, Alaska [abs.]: Palynology, v. 11, p. 227-228.

*Frederiksen, N.O., *Ager, T.A., and *Edwards, L.E., 1988, Palynology of Maastrichtian and Paleocene rocks, lower Colville River region, North Slope of Alaska: Canadian Journal of Earth Sciences, v. 25, no. 4, p. 512-527.

*Frost, T.P., *Calzia, J.P., *Vivit, D.V., and *Kistler, R.W., 1988, Cretaceous-Early Tertiary granitoids of the Bethel quadrangle, southwestern Alaska: A preliminary report [abs.]: Geological Society of America Abstracts with Programs, v. 20, no. 3, p. 162.

*Fuis, G.S., *Ambos, E.L., *Mooney, W.D., *Page, R.A., *Plafker, George, *Nokleberg, W.J., *Campbell, D.L., *Fisher, M.A., and *Brocher, T.M., 1988, Tectonic evolution of southern Alaska [abs.]: Eos, v. 69, no. 16, p. 266.

*Fuis, G.S., and *Plafker, George, 1988, Evolution of the deep 
structure of southern Alaska along the TACT route [abs.]: Eos, p. 1452.

*Gamble, B.M., 1987, Gold veins of the Seward Peninsula, Alaska [abs.], in FIR, p. 125 [also in USGS Circular 995, p. 23].

Gardner, M.C., Bergman, S.C., Cushing, G.W., MacKevett, E.M., Jr., *Plafker, George, Campbell, R.B., Dodds, C.J., McClelland, W.C., and Mueller, P.A., 1988, Pennsylvanian pluton stitching of Wrangellia and the Alexander terrane, Wrangell Mountains, Alaska: Geology, v. 16, no. 11, p. 967-971.

*Gautier, D.L., 1987, Petrology and diagenesis of Cretaceous and Tertiary reservoir sandstones of the Arctic National Wildlife Refuge, Alaska [abs.], in AGS.

${ }^{*}$ Geist, E.L., *Brocher, T.M., *Fisher, M.A., and *Nokleberg, W.J., 1988, High-resolution seismic reflection/refraction images across the Denali fault, central Alaska [abs.]: Eos, p. 1457.

${ }^{*}$ Geist, E.L., *Childs, J.R., and *Scholl, D.W., 1987, Evolution and petroleum geology of Amlia and Amukta intra-arc summit basins, Aleutian Ridge: Marine and Petroleum Geology, v. 4, no. 4, p. 334-352.

1988, The origin of summit basins of the Aleutian Ridge: Implications for block rotation of an arc massif: Tectonics, v. 7, no. 2, p. 327-341.

${ }^{*}$ Goldfarb, R.J., *Leach, D.L., *Light, T.D., *Paterson, C.J., *Pickthorn, L.B., and *Pickthorn, W.J., 1987, The Juneau gold belt: A mother lode-type system in southeastern Alaska [abs.], in FIR, p. 140-141 [also in GSA Abstracts with Programs., v. 19, p. 382].

*Goldfarb, R.J., *Leach, D.L., *Miller, M.L., and *Pickthorn, W.J., 1988, Comment on the paper by K. Stuwe: Structural evolution of the Port Wells gold mining district, Prince William Sound, south-central Alaska: Implications for the origin of the gold lodes: Mineralium Deposita, v. 23 , no. 3 , p. 227-229 [also reply to comment].

*Goldfarb, R.J., *Leach, D.L., *Pickthorn, W.J., and Paterson, C.J., 1988, Origin of lode-gold deposit of the Juneau gold belt, southeastern Alaska: Geology, v. 16, no. 5, p. 440-443.

*Goldfarb, R.J., *Nelson, S.W., Berg, H.C., and *Light, T.D., 1987, Distribution of mineral deposits in the Pacific Border Ranges and Coast Mountains of the Alaskan Cordillera, in Geoexpo, p. 19-41.

${ }^{*}$ Hamilton, T.D., Craig, J.L., and Sellman, P.V., 1988, The Fox permafrost tunnel: A late Quaternary geologic record in central Alaska: Geological Society of America Bulletin, v. 100 , no. 6, p. 948-969.

*Hamilton, T.D., and *Robinson, S.W., 1988, Middle Wisconsin interstadial interval, central and northwest Alaska [abs.]: GSA, p. 208-209.

${ }^{*}$ Hamilton, Warren, 1988, [Book review of] Alaskan North Slope geology [by Irvin Tailleur and Paul Weimer, eds., Society of Economic Paleontologists and Mineralogists, Pacific Section, Bakersfield, Calif., 1987]: Eos (American Geophysical Union Transactions), v. 69, no. 38, p. 869.

Harbert, William, *Hillhouse, John, and *Vallier, Tracy, 1988, Northern hemisphere Early Permian paleolatitude of Wrangellia [abs.]: GSA, p. 234.

*Harris, A.G., 1987, Conodonts beyond palynomorphs, or how the world burns [abs.]: Palynology, v. 11, p. 232.

*Hildreth, Wes, Eichelberger, J.C., and Papike, J.J., 1987, Research drilling at Katmai (Alaska) [abs.], in IUGG, v. 2, p. 412.

*Hillhouse, J.W., and *Grommé, C.S., 1988, Early Cretaceous paleolatitude of the Yukon-Koyukuk province, Alaska: Journal of Geophysical Research, v. 93, no. 10B, p. $11,735-11,752$.

${ }^{*}$ Hodel, K.L., *Reimnitz, Erk, and *Barnes, P.W., 1988, Microtextures of quartz grains from modern terrestrial and subaqueous environments, North Slope of Alaska: Journal of Sedimentary Petrology, v. 58, no. 1, p. 24-32.

Houston, Heidi, and *Engdahl, E.R., 1988, A comparison of the spatial distribution of moment release with relocated seismicity for the 1986 Andreanof Islands earthquake [abs.]: Eos, p. 1303.

*Kelley, J.S., Foland, R.L., and *Molenaar, C.M., 1987, Structural framework of the Sadlerochit and Shublik Mountains and adjacent arctic coastal plain [abs.], in AGS.

Kisslinger, C., and *Engdahl, E.R., 1988, Aftershocks of the May 7, 1986 Andreanof Islands earthquake and their relation to pre-event seismicity [abs.]: Eos, p. 1303.

*Koski, R.A., 1988, Feromanganese deposits from the Gulf of Alaska Seamount Province: Mineralogy, chemistry, and origin: Canadian Journal of Earth Sciences, v. 25, no. 1, p. 116-133.

*Labson, V.F., *Fisher, M.A., and *Nokleberg, W.J., 1988, An integrated study of the Denali fault from magnetotelluric sounding, seismic reflection, and geologic mapping [abs.]: Eos, p. 1457.

*Lachenbruch, A.H., 1988, Permafrost temperature and the changing climate [abs.]: Eos, p. 1043.

Lafond, C.F., Levander, A.R., Beaudoin, B., *Page, R.A., *Fuis, G.S., and Stone, D.B., 1988, PASSCAL seismic reflection wave tests in the Brooks Range, arctic Alaska [abs.]: Eos, p. 1458.

${ }^{*}$ Lahr, J.C., *Page, R.A., and *Stephens, C.D., 1988, Unusual earthquakes in the Gulf of Alaska and fragmentation of the Pacific plate: Geophysical Research Letters, v. 15, no. 13, p. $1438-1486$.

Laughland, M.M., Underwood, M.B., *Wiley, T.J., and *Howell, D.G., 1988, Thermal-maturity inversion across the Glenn Creek fault, Kandik basin, Alaska [abs.]: GSA, p. 233-234.

${ }^{*}$ Leach, D.L., *Goldfarb, R.J., and *Hofstra, A.H., 1987, Fluid inclusion characteristics of the Juneau gold belt, southeastern Alaska [abs.], in FIR, p. 227-228. [Also in GSA Abs. with Progs., v. 19, p. 398.]

*Leach, D.L., *Goldfarb, R.J., and *Light, T.D., 1987, Fluid inclusion constraints on the genesis of the Alaska-Juneau gold deposit, in Geoexpo, p. 150-159.

Levander, A.R., Lafond, C.F., Beaudoin, B., *Fuis, G.S., *Page, R.A., and Stone, D.B., 1988, The PASSCAL wide-angle seismic experiment in the Brooks Range, arctic Alaska [abs.]: Eos, p. 1453.

Lewis, S.D., Ladd, J.W., and *Bruns, T.R., 1988, Structural development of an accretionary prism by thrust and strike-slip aulting: Shumagin region, Aleutian Trench: Geological Society of America Bulletin, v. 100, no. 5, p. 767-782.

*Light, T.D., *Tripp, R.B., and *King, H.D., 1987, Stream- 
sediment geochemistry of two mineral provinces in the Healy quadrangle, Alaska, in Geoexpo, p. 126-131.

Lindberg, D.R., and *Marincovich, Louie, Jr., 1988, New species of limpet from the Neogene of Alaska (Patellogastropoda: Mollusca): Arctic, v. 41, no. 3, p. 167-172.

*Lisowski, M., and *Savage, J.C., 1988, Deformation in the Yakataga seismic gap, southern Alaska, associated with the Gulf of Alaska earthquake of November 1987 and March 1988 [abs.]: Eos, p. 1439.

*Lisowski, M., *Savage, J.C., *Prescott, W.H., and *Gross, W.K., 1988, Absence of strain accumulation in the Shumagin seismic gap, Alaska, 1980-1987 [abs.]: Eos, v. 69 , no. 16, p. 271.

*Magoon, L.B., *Anders, D.E., and Banet, A.C., Jr., 1987, Petroleum geochemistry of oils and rocks in the Arctic National Wildlife Refuge, Alaska [abs.], in AGS.

Marincovich, Louie, Jr., 1988, Miocene mollusks from the lower part of the Bear Lake Formation on Ukolnoi Island, Alaska Peninsula, Alaska: Contributions to Science [Natural History Museum of Los Angeles County] no. 397,20 p.

*Marlow, M.S., *Cooper, A.K., *Dadisman, S.V., *Carlson, P.R., ${ }^{*}$ Geist, E.L., and Parson, L.M., 1988, Recent deformation along Bowers Ridge, Bering Sea: Evidence from GLORIA images and seismic-reflection data [abs.]: GSA, p. 128-129.

*Mayo, L.R., 1987, Cause of the advance of Hubbard Glacier, Alaska [abs.], in ASC, p. 49.

*McHugh, J.B., 1988, Concentration of gold in natural waters: Journal of Geochemical Exploration, v. 30, no. 1, p. 85-94 [includes data from Alaska].

*Menzie, W.D., Hua, Renmin, and *Foster, H.L., 1987, Newly located occurrences of lode gold near Table Mountain, Circle quadrangle, Alaska, in FIR, p. 264 [also in USGS Bull. 1682,13 p].

*Miller, T.P., 1988, Three volcanoes erupt in Alaska: Earthquakes and Volcanoes, v. 19, no. 6, p. 192-198, and photographs of Augustine on p. 235, and on backcover [Akutan, Pavlof, Augustine].

*Miller, T.P., and *Yount, M.E., 1987, Hazards, response, and effects of the 1986 eruption of Augustine Volcano, Alaska [abs.], in IUGG, v. 2, p. 429.

-1988, Successive Late Quaternary caldera-forming eruptions at the Emmons Lake volcanic center, Alaska Peninsula [abs.]: Eos, p. 1487.

*Miller, T.P., *Yount, M.E., and *Nelson, S.W., 1987, Pyroclastic flow characteristics during the initial phase of the 1986 eruption of Augustine Volcano, Alaska [abs.], in HVO, p. 175.

*Molenaar, C.M., and *Bird, K.J., 1987, Stratigraphy and reservoir rocks of the Arctic National Wildlife Refuge, Alaska [abs.], in AGS.

*Moll-Stalcup, Elizabeth, 1987, Bering Sea basalts [abs.], in HVO, p. 177.

*Molnia, B.F., 1988, Comparison of glacial-marine depositional environment of polar Antarctic and temperate Gulf of Alaska [abs.]: GSA, p. 84.

*Mosier, Elwin, *Cathrall, John, *Antweiler, John, *Tripp, Richard, Lueck, Larry, and Eakins, G.R., [1988], Gold occurrences and characteristics in the ChandalarKoyukuk area, in Placer 1987, p. 45-53.
Newberry, R.J., and *Brew, D.A., 1987, Geology and geochemistry of the Alaska-Juneau (AJ) mine area, Alaska [abs.], in FIR, p. 286 [also in Programs. with Abstracts, Symposium: Bulk mineable precious metal deposits of the western United States, 1987, Geological Society of Nevada, p. 57].

1988, Geology and geochemistry of the Alaska-Juneau (AJ) mine area, Juneau, Alaska [abs.], in Schafer, R.W., Cooper, J.J., and Vikre, P.G., eds., Bulk mineable precious metal deposits of the western United States, Symposium Proceedings, 1987: Reno, Nev., Geological Society of Nevada, p. 741.

*Nokleberg, W.N., Bundtzen, T.K., *Grybeck, Donald, and Smith, T.E., 1988, Metallogenesis of lode mineral deposits of mainland Alaska [abs.], in Deep Structure of the Pacific Ocean and its Continental Surroundings, International Symposium, Blagoveshchensk, USSR, 1988, Abstracts, p. 45-46. [Pacific Science Association, U.S.S.R., National Committee, Solid Earth Committee].

*Nokleberg, W.J., *Fisher, M.A., and *Labson, V.F., 1988, Geologic setting of major Cretaceous oblique underthrusting, eastern Alaska Range, Alaska [abs.]: Eos, p. 1452.

Page, R.A., *Fogleman, K.A., *Stephens, C.D., and *Lahr, J.C., 1988, State of stress in the subducted Pacific plate beneath Prince William Sound, southern Alaska [abs.]: Seismological Research Letters, v. 59, no. 1, p. 16.

Parrish, J.M., *Parrish, J.T., Hutchison, J.H., and Spicer, R.A., 1987, Late Cretaceous vertebrate fossils from the North Slope of Alaska and implications for dinosaur ecology: Palaios, v. 2, no. 4, p. 377-389.

*Parrish, J.T., and Spicer, R.A., 1988, Middle Cretaceous wood from the Nanushuk Group, central North Slope, Alaska: Palaeontology, v. 31, pt. 1, p. 19-34.

Pavlis, T.L., Sisson, V.B., *Nokleberg, W.J., *Plafker, George, and ${ }^{*}$ Foster, H., 1988, Evidence for Cretaceous crustal extension in the Yukon crystalline terrane, east-central Alaska [abs.]: Eos, p. 1453.

*Pickthorn, W.J., 1987, Stable isotope characteristics of the Juneau gold belt, Alaska [abs.], in FIR, p. 311 [also in GSA Abstracts with Programs., v. 19, p. 440].

*Pickthorn, W.J., *Goldfarb, R.J., and *Leach, D.L., 1987, "Mesothermal" gold-a metamorphic connection? [abs.], in FIR, p. 311-312 [Also in USGS Circ. 995, p. 57].

*Plafker, George, 1988, Synopsis of the Phanerozoic tectonic evolution of Alaska [abs.]: GSA, p. 133.

*Power, John, Kienle, Juergen, and Davies, J.N., 1988, Seismicity associated with the 1986 eruption of Mt. St. Augustine Volcano [abs.]: Eos, p. 1488.

*Rasmussen, L.A., 1988, Bed topography and mass-balance distribution of Columbia Glacier, Alaska, U.S.A., determined from sequential aerial photography: Journal of Glaciology, v. 34, no. 117, p. 208-216.

*Riehle, J.R., and *Brew, D.A., 1987, Pyroclastic deposits of the Edgecumbe volcanic field, Kruzof Island, Alaska, and some speculations about their origin [abs.], in $\mathrm{HVO}$, p. 210.

Roeske, S.M., and *Patton, W.W., Jr., 1988, Early Cretaceous metamorphism and deformation of the northeast Ruby terrane and overlying phyllite and ophiolite belts, east- 
central Alaska [abs.]: Geological Society of America Abstracts with Programs, v. 20, no. 3, p. 225.

*Ryan, H.F., and *Scholl, D.W., 1988, A shear zone imaged seaward of the forearc basin along the central Aleutian convergent margin [abs.]: GSA, p. 62.

${ }^{*}$ Savage, J.C., and *Lisowski, M., 1988, Deformation in the Yakataga seismic gap, southern Alaska, 1980-1986: Journal of Geophysical Research, v. 93, no. 5, p. 4731-4744.

${ }^{*}$ Schmidt, J.M., 1988, Mineral and whole-rock compositions of seawater-dominated hydrothermal alteration at the Arctic volcanogenic massive sulfide prospect, Alaska: Economic Geology, v. 83 , no. 4, p. 822-842.

${ }^{*}$ Schmidt, J.M., and *Zierenberg, R.A., 1988, Lateral variations of ore, and reconstruction of the Red Dog $\mathrm{Zn}$ $\mathrm{Pb}-\mathrm{Ag}$ deposit, Noatak district, Alaska [abs.]: GSA, p. 37.

${ }^{*}$ Scholl, D.W., *Grantz, Arthur, and *Vedder, J.G., 1988, Geology and resource potential of the continental margin of western North America and adjacent ocean basins-Beaufort Sea to Baja California: Circum-Pacific Council for Energy and Mineral Resources, Circum-Pacific Earth Science Series, v. 6, 799 p. [available from American Association of Petroleum Geologists].

${ }^{*}$ Scholl, D.W., *Ryan, H.F., *Geist, E.L., *Vallier, T.L., *Stevenson, A.J., and *Childs, J.R., 1988, Structural and stratigraphic evolution of Aleutian convergent margin basins-ridge crest to trench floor [abs.]: American Association of Petroleum Geologists Bulletin, v. 72, no. 2, p. 245.

*Scholl, D.W., *Stevenson, A.J., *Vallier, T.L., *Ryan, H.H., and *Geist, E.L., 1988, Arc-massif shearing, block rotation, and transportation-an Aleutian perspective of production and lateral dispersal of arctectonostratigraphic terranes [abs.]: GSA, p. 128.

${ }^{*}$ Schwab, W.C., and *Lee, H.J., 1988, Causes of two slopefailure types in continental-shelf sediment, northeastern Gulf of Alaska: Journal of Sedimentary Geology, v. 58, no. 1, p. 1-11.

*Schwab, W.C., *Lee, H.J., and *Molnia, B.F., 1988, Causes of varied sediment gravity flow types on the Alsek prodelta, northeast Gulf of Alaska: Marine Geotechnology, v. 7, no. 4 , p. $317-342$.

*Schwab, W.C., and Molnia, B.F., 1987, Unusual bed forms on the North Aleutian Shelf, Bristol Bay, Alaska: GeoMarine Letters, v. 7, no. 4, p. 207-215.

*Sipkin, S.A., 1988, A low-q zone beneath the Aleutian backarc basin and central Alaska from an analysis of multiple-
ScS phases [abs.]: Eos, p. 1318.

*Stanley, W.D., *Labson, V.F., *Csejtey, Béla, *Nokleberg, W.J., and *Long, C.L., 1988, Accretionary development of the Alaska Range: Evidence for suturing and thinskinned tectonics from magnetotellurics [abs.]: GSA, p. 183-184.

*Stephens, C.D., *Lahr, J.C., *Page, R.A., and *Fogleman, K.A., 1988, The northern Gulf of Alaska earthquakes of 17 November $\left(6.9 \mathrm{M}_{\mathrm{s}}\right)$ and 30 November $\left(\mathrm{M}_{\mathrm{B}} 7.6\right) 1987$ : Rupture of the Pacific plate south of the Yakataga seismic gap [abs.]: Seismological Research Letters, v. 59, no. 1, p. 21 .

*Stevenson, A.J., *Karl, H.A., *Gardner, J.V., *Cooper, A.K., ${ }^{*}$ Carlson, P.R., and *Edwards, B.D., 1988, Slope failure and sediment mass movement on the margins of the Aleutian basin, styles and causes [abs.]: GSA, p. 129.

Symonds, R.B., Rose, W.I., *Briggs, P., and Gerlach, T.M., 1988, The speciation and fluxes of gases at Augustine Volcano, Alaska: The degassing of a Cl-rich volcanic system [abs.]: Eos, p. 1469.

Symonds, R.B., Rose, W.I., Reed, M.H., *Briggs, Paul, and Gerlach, T.M., 1987, The speciation and fluxes of gases from Augustine Volcano, Alaska: A system rich in halides and transition metals [abs.], in HVO, p. 247.

*Till, A.B., 1988, Evidence for two Mesozoic blueschist belts in the hinterland of the western Brooks Range fold and thrust belt [abs.]: GSA, p. 112.

*Till, A.B., *Schmidt, J.M., and *Nelson, S.W., 1988, Thrust involvement of metamorphic rocks, southwestern Brooks Range, Alaska: Geology, v. 16, no. 10, p. 930-933.

*Trabant, D.C., 1987, Glacier motion by telemetered satellite navigation positions [abs.], in ASC, p. 51.

[U.S. Geological Survey] Bering Sea E.E.Z.-Scan 86 Group, 1987, Scientists mapping Alaskan coast line: Geotimes, v. 32, no. 8 , p. 15-16.

Wahrhaftig, Clyde, 1987, Foreword, in Giardino, J.R., Shroder, J.F., Jr., and Vitek, J.D., Rock glaciers: Boston, Mass., Allen \& Unwin, p. vii - xii.

Whitney, J.W., Wallace, W.K., and *Moore, T.E., 1987, Neotectonics of arctic Alaska-search for the arctic boundary between the Eurasian and North American Plates [abs.], in ASC, p. 72.

*Yount, M.E., and *Miller, T.P., 1987, The April 1986 eruptive phase of Augustine Volcano and associated hazards [abs.], in HVO, p. 276.

*Zierenberg, R.A., and *Schmidt, J.M., 1988, Isotopic evidence for multiple sulfur sources at the Red Dog $\mathrm{Zn}-\mathrm{Pb}-\mathrm{Ag}$ deposit, Noatak district, Alaska [abs.]: GSA, p. 37. 


\section{SELECTED SERIES OF U.S. GEOLOGICAL SURVEY PUBLICATIONS}

\section{Perlodicals}

Earthquakes \& Volcanoes (issued bimonthly).

Preliminary Determination of Epicenters (issued monthly).

\section{Technical Books and Reports}

Professional Papers are mainly comprehensive scientific reports of wide and lasting interest and importance to professional scientists and engineers. Included are reports on the results of resource studies and of topographic, hydrologic, and geologic investigations. They also include collections of related papers addressing different aspects of a single scientific topic.

Bulletins contain significant data and interpretations that are of lasting scientific interest but are generally more limited in scope or geographic coverage than Professional Papers. They include the results of resource studies and of geologic and topographicinvestigations; as well as collections of short papers related to a specific topic.

Water-Supply Papers are comprehensive reports that present significant interpretive results of hydrologic investigations of wide interest to professional geologists, hydrologists, and engineers. The series covers investigations in all phases of hydrology, including hydrogeology, availability of water, quality of water, and use of water.

Cir'culars present administrative information or important scientific information of wide popular interest in a format designed for distribution at no cost to the public. Information is usually of short-term interest.

Water-Resources Investigations Reports are papers of an interpretive nature made available to the public outside the formal USGS publications series. Copies are reproduced on request unlike formal USGS publications, and they are also available for public inspection at depositories indicated in USGS catalogs.

Open-File Reports include unpublished manuscript reports, maps, and other material that are made available for public consultation at depositories. They are a nompermanent form of publication that may be cited in other publications as sources of information.

\section{Maps}

Geologic Quadrangle Maps are multicolor geologic maps on topographic bases in 7 1/2-or 15-minute quadrangle formats (scales mainly $1: 24,000$ or $1: 62,500$ ) showing bedrock, surficial, or engineering geology. Maps generally include brief texts; some maps include structure and columnar sections only.

Geophysical Investigations Maps are on topographic or planimetric bases at various scales; they show results of surveys using geophysical techniques, such as gravity, magnetic, seismic, or radioactivity, which reflect subsurface structures that are of economic or geologic significance. Many maps include correlations with the geology.

Miscellaneous Investigations Series Maps are on planimetric or topographic bases of regular and irregular areas at various scales; they present a wide variety of format and subject matter. The series also includes 71/2-minute quadrangle photogeologic maps on planimetric bases which show geology as interpreted from aerial photographs. Series also includes maps of Mars and the Moon.
Coal Investigations Maps are geologic maps on topographic or planimetric bases at various scales showing bedrock or surficial geology, stratigraphy, and structural relations in certain coal-resource areas.

Oll and Gas Investigations Charts show stratigraphic information for certain oil and gas fields and other areas having petroleum potential.

Miscellaneous Fleld Studies Maps are multicolor or black-andwhite maps on topographic or planimetric bases on quadrangle or irregular areas at various scales. Pre-1971 maps show bedrock geology in relation to specific mining or mineral-deposit problems; post-1971 maps are primarily black-and-white maps on various subjects such as environmental studies or wilderness mineral investigations.

Hydrologic Investigations Atlases are multicolored or black-andwhite maps on topographic or planimetric bases presenting a wide range of geohydrologic data of both regular and irregular areas; principal scale is $1: 24,000$ and regional studies are at $1: 250,000$ scale or smaller.

\section{Catalogs}

Permanent catalogs, as well as some others, giving comprehensive listings of U.S. Geological Survey publications are available under the conditions indicated below from the U.S. Geological Survey, Books and Open-File Reports Section, Federal Center, Box 25425, Denver, CO 80225. (See latest Price and Availability List.)

"Publications of the Geological Survey, 1879- 1961" may be purchased by mail and over the counter in paperback book form and as a set of microfiche.

"Publications of the Geological Survey, 1962-1970" may be purchased by mail and over the counter in paperback book form and as a set of microfiche.

"Publications of the U.S. Geological Survey, 1971- 1981" may be purchased by mail and over the counter in paperback book form (two volumes, publications listing and index) and as a set of microfiche.

Supplements for $1982,1983,1984,1985,1986$, and for subsequent years since the last permanent catalog may be purchased by mail and over the counter in paperback book form.

State catalogs, "List of U.S. Geological Survey Geologic and Water-Supply Reports and Maps For (State)," may be purchased by mail and over the counter in paperback booklet form only.

"Price and Availability List of U.S. Geological Survey Publicatlons," issued annually, is available free of charge in paperback booklet form only.

Selected coples of a monthly catalog "New Publications of the U.S. Geological Survey" available free of charge by mail or may be obtained over the counter in paperback booklet form only. Those wishing a free subscription to the monthly catalog "New Publications of the U.S. Geological Survey" should write to the U.S. Geological Survey, 582 National Center, Reston, VA 22092.

Note.--Prices of Government publications listed in older catalogs, announcements, and publications may be incorrect. Therefore, the prices charged may differ from the prices in catalogs, announcements, and publications. 
(2)

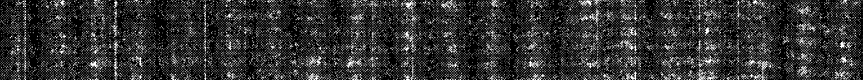

